\title{
Soil developments in salt marshes and on artificial islands in the Wadden Sea
}

\author{
Dissertation \\ zur Erlangung des mathematisch-naturwissenschaftlichen Doktorgrades \\ „Doctor rerum naturalium“ \\ der Georg-August-Universität Göttingen
}

im Promotionsprogramm Biologische Diversität und Ökologie der Georg-August-University School of Science (GAUSS)

vorgelegt von

\section{Thomas Dinter}

aus Recklinghausen

Göttingen, Juli 2018 



\section{Betreuungsausschuss}

Jun. Prof. Dr. Michaela Dippold

Abteilung Ökopedologie der Gemäßigten Zonen, Universität Göttingen

Prof. Dr. Michael Kleyer

Abteilung Landschaftsökologie, Universität Oldenburg

Prof. Dr. Stefan Scheu

Abteilung Tierökologie, Universität Göttingen

\section{Mitglieder der Prüfungskommission}

Jun. Prof. Dr. Michaela Dippold (Referent)

Abteilung Ökopedologie der Gemäßigten Zonen, Universität Göttingen

Prof. Dr. Michael Kleyer (Korreferent)

Abteilung Landschaftsökologie, Universität Oldenburg

\section{Weitere Mitglieder der Prüfungskommission}

Prof. Dr. Stefan Scheu

Abteilung Tierökologie, Universität Göttingen

PD Dr. Ina Meier

Abteilung Ökologie und Ökosystemforschung, Universität Göttingen

Prof. Dr. Mark Maraun

Abteilung Tierökologie, Universität Göttingen

Prof. i.R. Dr. Gerhard Gerold

Abteilung Physische Geographie, Universität Göttingen 

Dedicated to

My beloved parents

Dr. Wolfgang Dinter $\uparrow$

Anne-Margarethe Maas-Dinter $\dagger$ 



\section{Table of Contents}

Summary III

Zusammenfassung. ..V

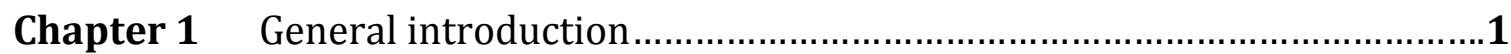

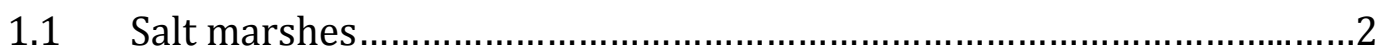

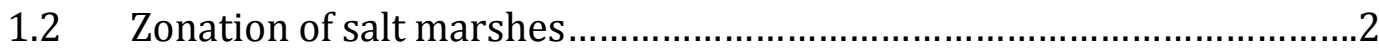

$1.3 \quad$ Interplay between biotic and abiotic factors ........................................ 4

1.4 Geomorphology and soil establishment in salt marshes of Spiekeroog........................................................... 6

$1.5 \quad$ Objectives of this thesis.................................................................

Chapter 2 Impact of sea level change on coastal soil organic matter, priming effects and microbial community assembly. .17

Chapter 3 Diversity of decomposing flies and carcass decay in experimental salt marsh islands of the North Sea, Germany. .53

Chapter 4 Global change effects on decomposition processes in tidal wetlands: implications from a global survey using standardized litter. .85

Chapter 5 Effects of inundation, nutrient availability and plant species diversity on fine root mass and morphology across a saltmarsh flooding gradient .119

Chapter 6 General discussion.................................................................159

$6.1 \quad$ Moisture and water level.............................................................161

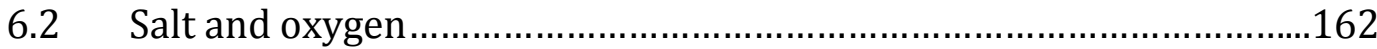

$6.3 \quad$ Nutrients and the priming effect......................................................164

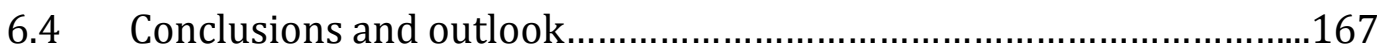


Appendix.

Acknowledgements

Curriculum Vitae.

.184

Declaration

185 


\section{Summary}

Salt marshes are located at the interface between marine and terrestrial ecosystems and inhabited by a unique and highly adapted flora and fauna. Requiring a moderate tidal range, salt marshes are characterised by a typical zonation: The pioneer zone represents the first elevation step above the tidal flat being daily flooded. It is followed by the lower salt marsh zone, as well as the upper salt marsh zone which is flooded only several times a year. Because of this wide range in inundation frequency, zones can be distinguished into a proximal area favoured by specialists and a competition-based environment in the areas more distal to the sea. While in the former, biota must cope with waterlogged, anoxic and saline soils, in the latter, plants compete for scarce nutrients in often depleted soils.

This thesis deepens the understanding of the interplay of abiotic factors in the salt marsh system induced by regular inundation and its consequences for carbon balances, basal environmental functions such as decomposition, as well as adaptations of biota to these stressful conditions.

In chapter 2 of this thesis, soils from the pioneer- and lower salt marsh zone were investigated concerning the turnover of soil organic matter (SOM) under artificially altered tidal inundation cycles in a laboratory setup. One focus was the priming effect (PE), describing short-term changes in the SOM-turnover induced by the input of certain substances or mechanical treatments of the soil. Moreover, the composition of the prokaryotic soil community accompanying the treatments of "alltime ebb", "all-time flooded" and (every eight hours) "changing water level (Tide)" was analysed. The aim was to investigate changes in the $\mathrm{CO}_{2}$-efflux, PE and community composition resulting from different soil sampling locations within the salt marsh and changed inundation cycles. Samples from the higher elevation showed higher $\mathrm{CO}_{2}$-efflux rates vs. samples from the low elevation due to higher SOM content. Cumulative $\mathrm{CO}_{2}$-efflux was highest in the "Tide"-treatment, whereas PE could only be verified under "all-time ebb" conditions. While cumulative $\mathrm{CO}_{2}$-results can be explained by oxygen conditions typical for these soils, PE was affected by changes in prokaryotic metabolism. With respect to prokaryotic community composition, 
evidence for temporal niche adaptation was found under applied water level treatments.

Chapter 3 represents a field study focussing on decomposition, a basal ecosystem service. Artificially constructed islands in the Wadden Sea were used as models for disturbed salt marsh systems. As a main hypothesis, we expected a slower decomposition activity on disturbed systems due to decomposer biodiversity loss. Within a two-week period, loss of biomass of an easily available substrate, decomposer diversity and soil nutrient status was recorded. Biomass loss was different between the salt marsh zones only on the reference plots, but not on the islands, with the most rapid loss in the upper salt marsh zone. Decomposer diversity correlated with salt marsh elevation. Carbon-to-nitrogen-ratio $(\mathrm{C} / \mathrm{N})$ declined with biomass loss due to protein enrichment of the topsoil during decomposition. Moreover, results showed a clear negative correlation between the $\mathrm{C} / \mathrm{N}$-ratio and species richness, leading to the conclusion of a higher decomposition rate and nutrient deliverance due to higher decomposer diversity.

In chapter 4, we examined the effects of temperature, sea level and coastal eutrophication on decomposition and stabilisation of SOM in tidal wetlands on a global scale. To achieve comparable results, we used two types of standardised litterbags and determined their initial weight and the biomass loss after a period of 90 days during which they were buried in the topsoil of mangrove and salt marsh systems. Whereas decomposition constant $k$ did not show significant results, stabilisation of SOM $(S)$ was negatively affected by higher mean temperatures and under more frequent inundation cycles.

Chapter $\mathbf{5}$ focussed on root traits of various salt marsh plants in conjunction with typical parameters of stress occurring in salt marsh ecosystems such as inundation, high salinity or anoxic soils. The main hypothesis was that sediment features, from oxygen status to nutrient status, shape root traits of salt marsh plants and that pioneer plants show a superior adaptation to tidal inundations which manifests in root-mass, -length, -area and -tissue density. As one root trait, fine root mass was highest in the lower salt marsh zone, indicating competition for nutrients in this zone of highest biodiversity. Fine root surface area was negatively correlated to nutrient load of the soil showing adaptations of plants to the nutrient-poor sites. 
Overall, I could show that tidal inundation is the key factor in salt marsh ecosystems which determines SOM, PE, decomposition as an ecosystem function and root traits. Regarding C-balances, inundation can lead to decreased $\mathrm{CO}_{2}$-efflux via decreased gas diffusion and decreased soil $\mathrm{C}$ sequestration via improved moisture supply. PE seems to be less expressed under flooded conditions due to differences in prokaryotic metabolisms compared to terrestrial systems. Using decomposition and root traits, this thesis shows that flooding frequency shapes local biodiversity resulting in shifts of ecosystem functions.

\section{Zusammenfassung}

Salzwiesen liegen an der Schnittstelle zwischen marinen und terrestrischen Ökosystemen und sind Lebensraum für eine einzigartige und äußerst gut angepasste Flora und Fauna. Auf einen moderaten Tidenhub angewiesen, sind Salzwiesen durch eine typische Zonierung gekennzeichnet: Die Pionierzone wird als erste Höhenstufe oberhalb der Wattfläche täglich überflutet. Auf sie folgen die Zone der unteren und der oberen Salzwiese; letztere wird nur einige Male im Jahr überflutet. Aufgrund dieser breiten Spanne in der Überflutungsfrequenz können die Zonen unterschieden werden in ein proximal zur See gelegenes Gebiet, welches von Spezialisten bevorzugt wird, sowie ein distal gelegenes, eher konkurrenzbasiertes Gebiet. Während im proximalen Gebiet Lebewesen mit wassergesättigt, anoxischen und salzhaltigen Böden zurechtkommen müssen, konkurrieren vor allem die Pflanzen in den distalen Gebieten um die knappen Nährstoffe in den oft verarmten Böden.

Diese Dissertation vertieft das Verständnis für die Interaktionen zwischen den abiotischen Faktoren im Ökosystem Salzwiese, welche durch regelmäßige Überflutungen verursacht werden, und deren Konsequenzen für Kohlenstoffbilanzen, grundlegende Umweltfunktionen wie Zersetzung als auch Anpassungen von Lebewesen an diese stressigen Bedingungen.

Im zweiten Kapitel dieser Arbeit wurden Bodenproben aus der Pionier - und unteren Salzwiesenzone im Labor unter künstlich veränderten Gezeitenzyklen auf den Umsatz organischer Bodensubstanz (soil organic matter - SOM) hin untersucht. Ein Schwerpunkt war hierbei der Priming-Effekt (PE), der kurzfristige 
Veränderungen des SOM-Umsatzes beschreibt, die durch den Eintrag bestimmter Stoffe oder mechanische Einflüsse auf den Boden hervorgerufen werden. Darüber hinaus wurde die Zusammensetzung der prokaryotischen Bodengemeinschaft analysiert, die in den einzelnen Versuchsansätzen „konstante Ebbe“, „konstante Überflutung“ und (alle acht Stunden) „wechselnder Wasserstand (Tide)“ vorkamen. Ziel war es, Veränderungen des $\mathrm{CO}_{2}$-Efflux, des PE und der Zusammensetzung der Lebensgemeinschaft infolge unterschiedlicher Bodenprobenahmepunkte innerhalb der Salzwiese und veränderter Überflutungszyklen zu untersuchen. Proben aus der höheren Zone wiesen höhere $\mathrm{CO}_{2}$-Effluxraten gegenüber Proben aus der unteren Zone, was auf dem höheren SOM-Gehalt beruht. Der kumulative $\mathrm{CO}_{2}$-Efflux war im „Tide“-Ansatz am höchsten, wohingegen ein PE nur im „Ebbe“-Ansatz nachgewiesen werden konnte. Während insgesamt gesehen die $\mathrm{CO}_{2}$-Ergebnisse durch für diese Böden typische Sauerstoffbedingungen erklärt werden können, wurde der PE durch Veränderungen im prokaryotischen Metabolismus beeinflusst. In Bezug auf die Zusammensetzung der prokaryotischen Bodengemeinschaft wurden Hinweise auf eine temporäre Nischenadaption durch die durchgeführten Veränderungen der Wasserstände gefunden.

In Kapitel 3 wurde eine Feldstudie durchgeführt, die sich auf die Zersetzung, eine grundlegende Ökosystemdienstleistung, konzentriert. Künstlich angelegte Inseln im Wattenmeer dienten als Modell für gestörte Salzwiesensysteme. Als eine Haupthypothese erwarteten wir eine verlangsamte Zersetzungsaktivität in gestörten Systemen aufgrund des Verlustes an Biodiversität von Zersetzern. Über einen Zeitraum von zwei Wochen wurde der Biomasseverlust eines leicht verfügbaren Substrates, die Zersetzervielfalt und den Bodennährstoffgehalt aufgezeichnet. Der Biomasseverlust unterschied sich zwischen den einzelnen Salzwiesenzonen nur auf den Referenzflächen, jedoch nicht auf den Inseln, wobei sich die schnellsten Verluste in der oberen Salzwiesenzone zeigten. Die Diversität der Zersetzer korrelierte mit der Höhe der Salzwiesenstufe. Das Kohlenstoff-Stickstoff-Verhältnis (C/N) nahm mit Verlust an Biomasse durch die Proteinanreicherung des Oberbodens während der Zersetzung ab. Darüber hinaus zeigten die Ergebnisse deutlich eine negative Korrelation zwischen dem $\mathrm{C} / \mathrm{N}$-Verhältnis und dem Artenreichtum, was auf eine höhere Zersetzungsrate und Nährstofffreisetzung aufgrund höherer Zersetzervielfalt schließen lässt. 
In Kapitel 4 haben wir auf globaler Ebene die Auswirkungen von Temperatur, Meeresspiegel und Küsteneutrophierung auf die Zersetzung und Stabilisierung von SOM in gezeitendominierten Feuchtgebieten untersucht. Um vergleichbare Ergebnisse $\mathrm{zu}$ erlangen, verwendeten wir zwei Arten von standardisierten Netzbeuteln und bestimmten ihr Anfangsgewicht und den Biomasseverlust nach einem Zeitraum von 90 Tagen, in denen sie im Oberboden von Mangroven- und Salzwiesensystemen vergraben waren. Während die Zersetzungs-konstante $k$ keine signifikanten Ergebnisse zeigte, wurde die Stabilisierung von SOM $(S)$ durch höhere mittlere Temperaturen und häufigere Überflutungszyklen negativ beeinflusst.

Kapitel 5 befasste sich mit den Wurzeleigenschaften verschiedener Salzwiesenpflanzen in Verbindung mit typischen Stressparametern im Ökosystem Salzwiese wie z.B. Überflutung, hohe Salinität oder anoxische Böden. Die Haupthypothese war, dass Sedimenteigenschaften, vom Sauerstoff- bis zum Nährstoffgehalt, die Wurzel-eigenschaften von Salzwiesenpflanzen prägen und dass Pionierpflanzen eine überlegene Anpassung an die Gezeitenüberflutungen zeigen, welche sich in Wurzelmasse, -länge, -fläche und -gewebsdichte äußern. Als eine der Wurzeleigenschaften war die Masse der Feinwurzeln in der unteren Salzwiesenzone am höchsten, was auf Nährstoffkonkurrenz in dieser Zone mit der höchsten Biodiversität hindeutet. Die Wurzeloberfläche der Feinwurzeln korrelierte negativ mit dem Nährstoffgehalt des Bodens und die Pflanzen wiesen Anpassungen an die nährstoffärmeren Standorte auf.

Insgesamt konnte ich zeigen, dass die Überflutung durch die Gezeiten der Schlüsselfaktor im Ökosystem Salzwiese ist, der die SOM, den PE, die Zersetzung als Ökosystemfunktion und die Wurzeleigenschaften bestimmt. In Bezug auf das Kohlenstoffgleichgewicht kann die Überflutung $\mathrm{zu}$ einem verringerten $\mathrm{CO}_{2}$-Efflux durch verminderte Gasdiffusion führen und zu geringerer C-Speicherung im Boden durch verbesserte Feuchtigkeitszufuhr. Der PE scheint aufgrund der Unterschiede im prokaryotischen Metabolismus im Vergleich $\mathrm{zu}$ terrestrischen Systemen unter Flutbedingungen weniger ausgeprägt $\mathrm{zu}$ sein. Anhand von Zersetzungs- und Wurzelmerkmalen zeigt diese Arbeit, dass die Häufigkeit von Überflutungen die lokale Biodiversität beeinflusst und zu einer Verschiebung der Ökosystemfunktionen führt. 
Summary/Zusammenfassung 


\section{Chapter 1}

General introduction

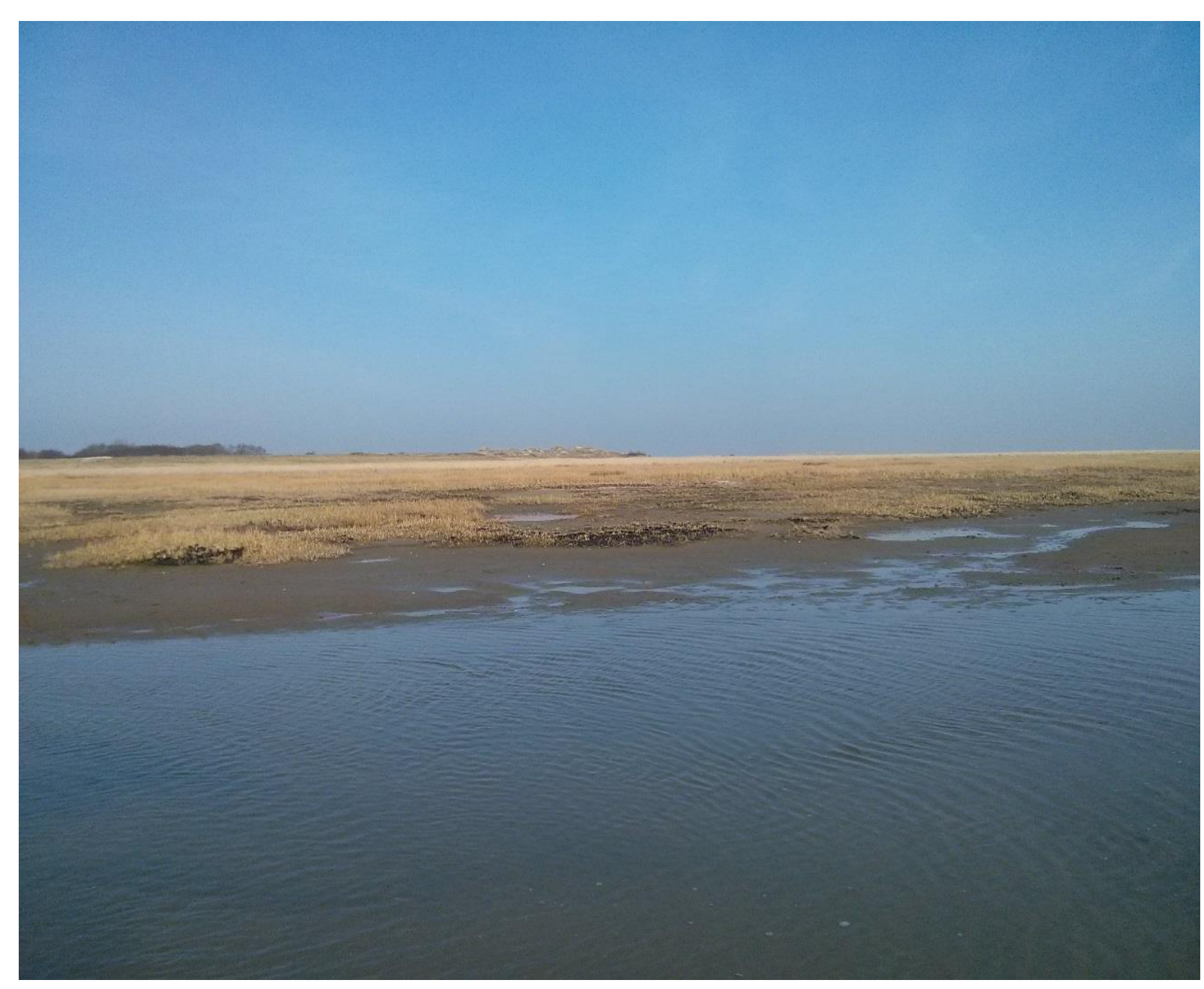




\subsection{Salt marshes}

Wetlands are areas governed by the temporal or permanent presence of water. Covering up to $7.6 \%$ of the earth's surface (8-10 million $\mathrm{km}^{2}$; Lehner \& Döll, 2004), wetlands are ubiquitous and can be found on every continent except for Antarctica (Finlayson \& Davidson, 1999). Coastal subsets of wetlands are mangroves and salt marshes. Whereas the former are mainly found within tropical and sub-tropical latitudes, the latter are more typical for temperate zones (Kathiresan \& Bingham, 2001; Saintilan et al., 2014). Salt marshes occur at shallow water depths and represent unique transitional ecosystems between land and sea which feature adaptions to extreme conditions such as salt stress or anoxia (e.g. Vernberg, 1993; Allen, 2000; Bakker, 2014). Moreover, these marshes represent one of the most productive ecosystems on earth and exhibit an enormous carbon sequestration capability (Kirwan et al., 2013).

These ecosystems are in constant balance between erosion by wave energy and accretion of sediment particles by plants and biofilms. As this resembles the legendary ride on a razor blade and implies survival or perish, several studies have discussed this geomorphological topic in greater detail (e.g. Bakker et al., 1993; Reed, 1995; Allen, 2000; Pedersen \& Bartholdy, 2006; Andersen et al., 2011). Salt marshes degrade if timespan of inundation is too high. In contrast, salt marsh elevation rises beyond direct impact of the sea in the opposite scenario, in which plants trap more and more sediment and deposited organic material is not washed away within a short duration by daily tidal inundation. This process is accompanied by typical indicators of "terrestrification" such as a decrease in soil salinity and water content, an increase in the carbon/nitrogen $(\mathrm{C} / \mathrm{N})$ ratio and the transition from a massive to a crumble soil structure with higher bulk density (Giani \& Landt, 2000).

\subsection{Zonation of salt marshes}

Representing the dominating driving force on biotic and abiotic factors in salt marsh systems, inundation frequency shapes characteristic domains of similar habitats within the salt marsh ecosystem (Bockelmann et al., 2002). This zonation follows a distinctive pattern and hence each step can be allocated to a certain stage of salt 


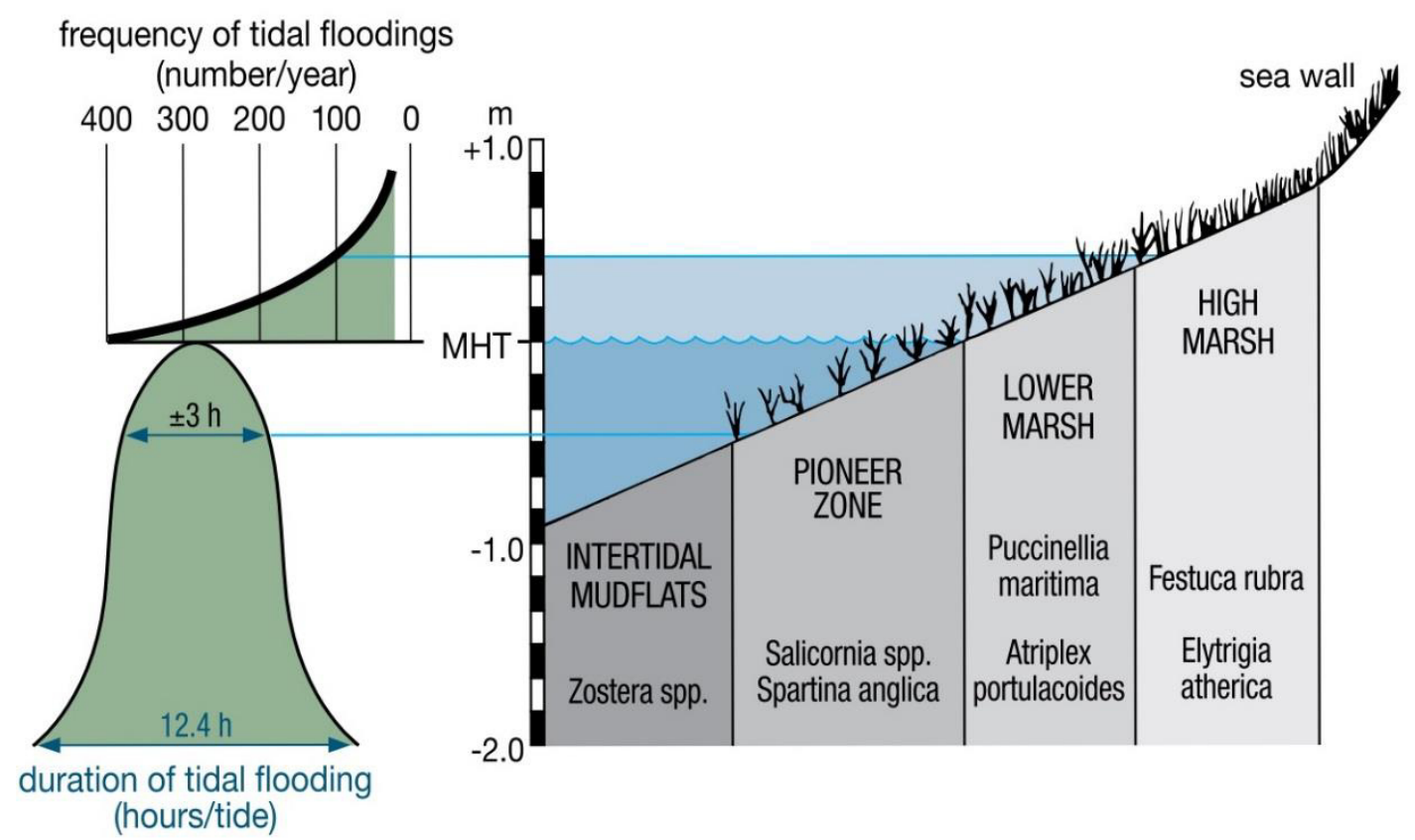

Figure 1.1 Left Mean frequency of tidal flooding events per year and duration of flooding per day; Right Salt marsh zonation with typical plant species in pioneer zone (Pio), lower marsh zone (Low) and high/upper marsh zone (Upp) (DeVlas et al., 2013).

marsh development (Figure 1.1). During an initial phase an elevated spot of sand may emerge from the tidal flat by hydrodynamic and/or aeolic processes (Marani et al., 2006), which is then less inundated compared to the surrounding system allowing first settlement of pioneer species such as glasswort (Salicornica spp.) or cordgrass (Spartina anglica) (Redelstein et al., 2018, see Chapter 5). This stage of salt marsh establishment, which is flooded twice a day, is called the pioneer zone (Pio). It is inhabited by specialists capable of tolerating extreme abiotic conditions, such as cordgrass that actively excretes excess saltwater to maintain osmotic potentials (Sleimi \& Abdelly, 2003; Mahon \& Carman, 2008). Furthermore, established plants retard water movement allowing the retention of finer particles (Gleason et al., 1979; Yang, 1998). These processes enable the marsh to rise in elevation above mean high tide (MHT), being then called lower salt marsh zone (Low). Here, sea meadow (Puccinella maritima) and sea aster (Aster tripolium) dominate the plant community (Kiehl et al., 1997). Moreover, Low is inundated only during spring tides and thus the mean grain size is lower compared to Pio since more silt particles have time to reach the sediment (Kolditz et al., 2012). When sediment trapping continues and inundation frequency decreases further to just major storm events, a third salt marsh 
zone establishes, the upper salt marsh zone (Upp). In Upp, environmental factors are less restrictive, and specialists are outcompeted by new plant species (Levine et al., 1998). The high competitive potential of red fescue (Festuca rubra) and other salt marsh grass families facilitates their dominance in this zone (Silvertown et al., 1994).

\subsection{Interplay between biotic and abiotic factors}

There are numerous closely linked biotic and abiotic factors shaping a salt marsh system. In the following, an excerpt of these connections and dependencies between biotic and abiotic processes will be introduced to stress the complexity and uniqueness of the salt marsh ecosystem (Figure 1.2).

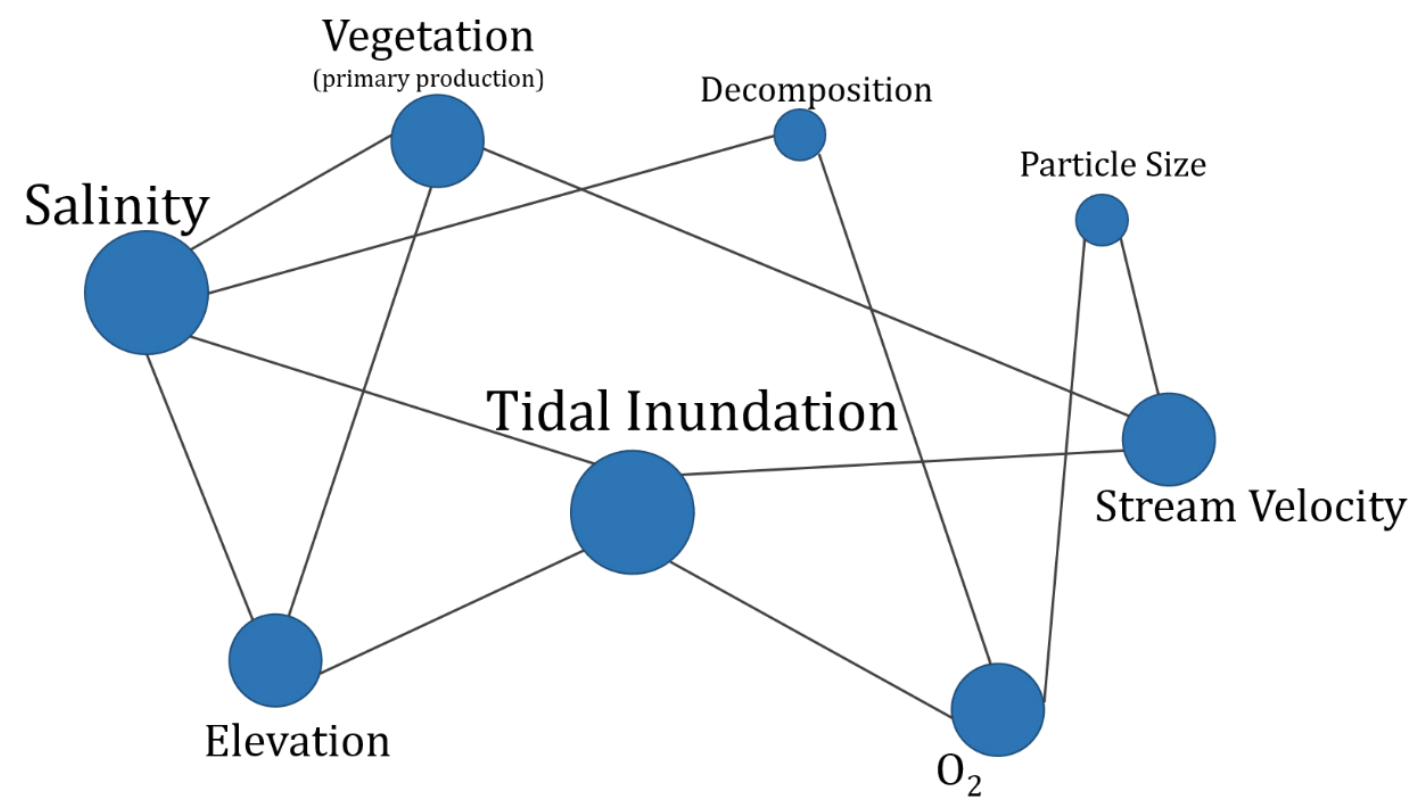

Figure 1.2 Illustration of exemplary relations between biotic and abiotic factors in the salt marsh ecosystem

As previously described, the zonation of salt marshes is a direct consequence of changes in inundation frequency. Zedler and Kercher (2005) point out that since wetlands are defined by hydrologic conditions, change in water volume and nutrient load threatens the integrity of salt marshes. If duration of inundation is high, a greater water body reaches the marsh, and accordingly, mean wave energy is also higher as energy loss by friction at the sediments surface is smaller (Graw, 1995). In the presence of aquatic plants stream velocity can be decreased and transformed into turbulent kinetic energy (Nepf, 1999). Moreover, a change in stream velocity results 
in different patterns concerning sedimentation or erosion of particles and movement of biota (Vernberg, 1993). As a result, mean grain size declines from Pio to Upp in mineral marsh soils. Particle size distribution itself has an impact on oxygen supply of the soil: Clayey soils hamper gas diffusion and exchange with the atmosphere leading to hypoxic or anoxic conditions in depths of centimetres or even few millimetres within the sediment (Cannavo \& Michel, 2013). This process is facilitated in simultaneous occurrence of high contents of soil organic matter (SOM), which is often concomitant found in clay rich soils.

However, simply due to the constant supernatant water, salt marsh soils are prone to anoxic conditions. If the demand for $\mathrm{O}_{2}$ within the sediment is higher than the relatively slow molecular gas diffusion from the overlying water column, anoxic conditions are the consequence (Hedges \& Oades, 1997). As a prime key for understanding processes in salt marshes tidal inundation, shows more vectors influencing this ecosystem: Evidently, soil water salt concentrations are highly dependent on tidal influence. A reduction of tidal inundation frequency by higher marsh elevation leads to lower salinity due to dilution by rainfall (Bertness \& Leonard, 1997). Moreover, continued increase in ebb duration leads to initial colonisation by pioneer plants on elevated patches reducing salinity even further by shading soil surface, which reduces evaporation (Bertness, 1991). An indirect factor to decrease salinity through vegetation and primary production is caused by increased sediment trapping and organic matter accumulation leading to a higher surface elevation and hence rarer inundation (Reed, 1995; Olff et al., 1997; Darby \& Turner, 2008). However, salinity as a secondary factor of influence also shapes salt marsh vegetation. Due to the close proximity to the sea, salt concentrations within salt marsh soils are so high, that most plant species are either halophytic or can at least tolerate considerable amounts of salt in the soil. Bakker (2014) mentions two important mechanisms of how salt marsh plants cope with high salinity in the rhizosphere: The first strategy is applied by sea lavender (Limonium vulgare) or the already mentioned cordgrass (Spartina anglica) which includes active excretion of salt through salt glands. A second mechanism involves the dilution of salt water by fresh water resulting in swelling of plant tissue. The latter is a typical strategy for succulents such as glasswort (Salicornica spp). However, not only plant production but also decomposition appears to be influenced by salinity: Hemminga and 
colleagues (Hemminga \& Buth, 1991; Hemminga et al., 1991) supposed, that a high salinity status hampers decomposition. Another control concerning decomposition is availability for oxygen: Since suboptimal electron acceptors such as nitrate $\left(\mathrm{NO}_{3}^{-}\right)$or sulphate $\left(\mathrm{SO}_{4}{ }^{2-}\right)$ have to be used, decomposition is slower under anaerobic conditions (Kristensen \& Holmer, 2001). Reciprocally, high amounts of SOM and high decomposition rates lead to oxygen depletion in bottom water, as mentioned before (Cloern, 2001).

\subsection{Geomorphology and soil establishment in salt marshes of}

\section{Spiekeroog}

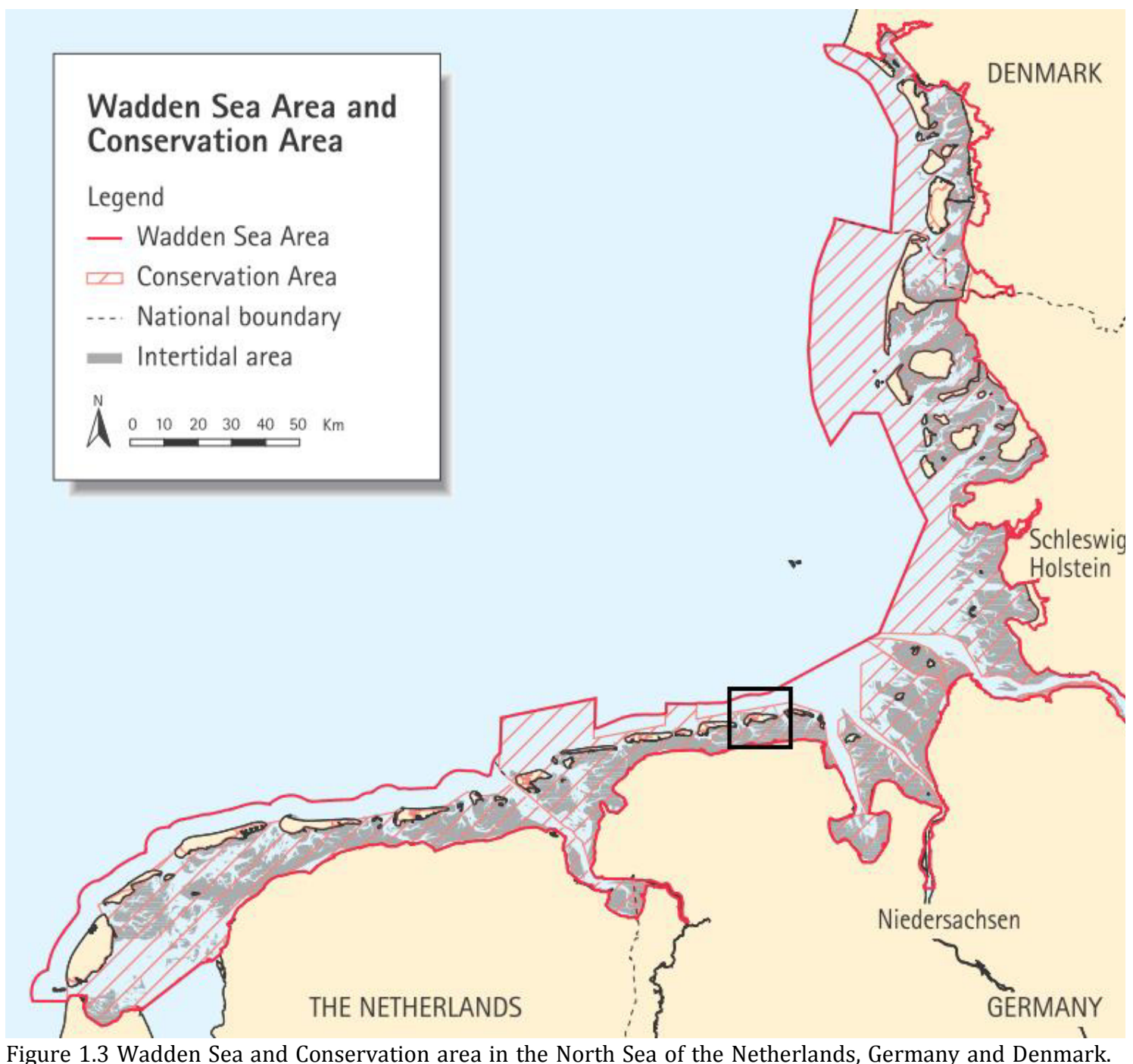

Figure 1.3 Wadden Sea and Conservation area in the North Sea of the Netherlands, Germany and Denmark Black box shows the location of Spiekeroog as part of the barrier island system (Wolff et al., 2010). 
This study was carried out in the salt marshes of Spiekeroog (53⒋ $46^{\prime} 13.5^{\prime \prime N}$ $7^{\circ} 41^{\prime} 42.6 " \mathrm{E}$ ), a barrier island in the northwest of Germany, which separates, along with other islands, the Wadden Sea from the North Sea (Figure 1.3). The Wadden Sea and its salt marshes is worldwide unique in its size and exhibits one of the highest primary production rates. It covers about $14.700 \mathrm{~km}^{2}$ with $11.200 \mathrm{~km}^{2}$ protected by a nature reserve (Wolff et al., 2010).

From a geological perspective, the Wadden Sea, Spiekeroog and the salt marshes are of very young age. The area was covered by glaciers in the Saale glaciation during Pleistocene (Beck et al., 2011). In early Holocene (app. 8000 BC) the transgressing North Sea reached the East Frisian Islands and Spiekeroog (Pott, 1995). Rapid sea level rise was mainly triggered by successive ice melting (eustatic sea level rise) during interglacial periods such as the Atlantic around 4000 BC (Köhn, 1991). Another important factor to consider concerning the documented rapid transgression is the isostatic compensation during deglaciation in Scandinavia: With a lowered ice load, the earth's crust beneath Scandinavia rose (and rises until today at smaller rates), depressing the crust beneath the North Sea deeper into the earth's mantle. However, Kiden and colleagues (2002) point out that the influence of isostatic sea level changes is geographically quite heterogenic. When sea level rise slowed down in Mid-Holocene, mineral sediments and "swimming" turfs established in an alternating pattern right on top of Pleistocene sediments under the influence of constant transgression and regression cycles (Streif, 2004). The formation of Spiekeroog and the other East Frisian islands during the last few thousand years was discussed in different theories (e.g. Penck, 1894; Lüders, 1953; Barckhausen, 1969).

The currently accepted theory describes Spiekeroog as an island which was formed by sedimentation of Holocene sediments around a geest, a residual of glacial deposition (Streif, 1990). Under the influence of complete, temporal inundations, Spiekeroog became a barrier island by breaking wave currents and sedimentation of marine sediments. When elevation reached the top of mean high tide, establishment of dunes and constant vegetation was possible (Reineck, 1994). According to Streif (1990), recent geomorphology of Spiekeroog is uncoupled from former geest landscape and follows a strictly marine morphodynamic. Therefore, erosion and sediment supply follow a West-to-East-pattern. Approximately $70 \%$ of water passes through the Otzumer Balje, separating Spiekeroog from Langeoog which enhances 
the pressure on the western coast of Spiekeroog (Niesel \& Dietmann, 1999). Simultaneously, a southward drift occurs triggered by northward transgression from the North Sea (Streif, 1990).

All previously mentioned processes and many others result in a gradual establishment of initial soils from marine sediments by geogenic and pedogenic processes (Pons \& Zonneveld, 1965). Geogenic processes in this respect are sediment transport and deposition by changes in tidal inundation and hydrodynamics. Geogenic processes are drainage and aeration by reduced inundation and increased elevation, reduced salinity and enhanced decomposition (Giani \& Landt, 2000). The so called "Salic Fluvisol" (WRB, 2014) is comparable to the German term "Rohmarsch" and is typically characterised by a threefold layering of Ai/Ah - Go - Gr: In the top layer (Ah), high contents of humic substances are found in accordance with higher silt or clay proportions as compared to the other soil horizons. Go and Gr are mostly sandy horizons with occasional layers of silt, clay or calcareous debris from storm currents. They are distinguishable from each other by an absence of oxidised iron in Gr induced by constant water saturation. The well-known black colour and smell of "rotten eggs" of Gr horizons is mainly derived from iron and sulphur being microbiologically reduced within the sediment. In tendency, the salt marsh soils of Spiekeroog can be considered relatively young, as they still contain considerable amounts of carbonate. During aging, carbonate is lost through oxidation of iron sulphide by microbes leading to the production of sulfuric acid together with carbonic acid from the decomposition of organic material (Schachtschabel et al., 1992).

\subsection{Objectives of this thesis}

This thesis deals with various aspects of soil development, nutrient traits and ecosystem functioning within the margin of a fast-changing environment like the salt marsh system. To assess the numerous issues of this attempt, four studies were carried out focussing on different aspects of the salt marsh soil system of Spiekeroog. 


\section{Chapter 2}

This chapter aims on dynamics of SOM and a phenomenon called "Priming Effect" in salt marsh soils. The Priming Effect describes a change in mineralization rate of recalcitrant SOM when labile organic matter is added to the system. It is well known for terrestrial systems but knowledge for coastal ecosystems is scarce. A microcosm experiment was set up with soils from Pio and Low, and three different inundation scenarios: Two scenarios included an all-time ebb and an all-time flood treatment, while the third scenario was adapted to the natural salt marsh system by flooding and drainage every six hours. After preincubation, priming was induced using labelled ${ }^{14} \mathrm{C}$-glucose. Over 56 days we measured $\mathrm{CO}_{2}$-efflux and shifts in prokaryotic community composition. We found evidence, that priming is affected by duration of inundation and salt marsh elevation. Changes in prokaryotic community were also related to both factors. Overall, priming appears to be of minor importance in marine systems compared to terrestrial environments, but $\mathrm{CO}_{2}$-dynamics and community composition are highly dependent on inundation status of the soil.

\section{Chapter 3}

In this field study, we used the artificial/experimental islands and onshore plots constructed during the BEFmate project (for more information: See Appendix and Balke et al. 2017). We assessed the basic ecosystem functions of the experimental islands and onshore control plots by decomposition of a rapidly available substrate. Therefore, we sampled 264 pieces of meat from all three salt marsh zones and both treatments (pure sand vs. sods from Low). Within a two-week period, we analysed weight loss, nutrient release and arthropod community composition inside and beneath decomposing pieces of meat and linked the results to ecosystem disturbance. Arthropod community composition and nutrient status of the soil differed depending on decomposition state, plot treatment and salt marsh elevation. Moreover, we found evidence that maggot species richness had a clear impact on the carbon vs. nitrogen ratio. It can be concluded from the results that salt marsh elevation has a high influence on decomposer biodiversity which in turn enhances or hampers decomposition of easily available substrates. 


\section{Chapter 4}

The goal of this study was to compare different salt marsh and mangrove sites distributed over four continents in view of their sensitivity in carbon sequestration in dependence of temperature, sea level rise and eutrophication status. 15 scientists supplied decomposition and stabilisation data from 25 wetland sites, which were obtained using standardised plant litter. Stabilisation of organic matter, which is a key function of salt marsh and mangrove ecosystems, making them an important determinator of the global carbon cycle, was highly affected by mentioned boundary variables. One site was especially prone to changes in eutrophication which leads to disturbing questions about future sequestration capacities of tidal wetlands if temperature, sea level and nutrient status of coastal habitats stay in their current upward trends.

\section{Chapter 5}

In this study, various soil parameters ( $\mathrm{C}, \mathrm{N}$, grain size distribution, $\mathrm{pH}$, bulk density, $\mathrm{Na}, \mathrm{S}$ and plant available $\mathrm{P}$ ) in correlation with inundation frequency and plant species diversity were compared to different root traits (fine root mass, -morphology and -distribution) at two salt marsh sites of the German North Sea coast (Spiekeroog and Westerhever). Samples were taken from all three soil horizons (Ai/Ah, Go and Gr) and from all three elevation zones (Pio, Low, Upp). Grain size distribution and nutrient contents differed among sites. Fine root mass was linked to mentioned soil parameters but also to salt marsh zone and plant species diversity. Fine root surface area was mainly influenced by ambient nutrient status of the soil. Plant root traits in salt marsh ecosystems are well adapted to prevailing conditions and governed mainly by species identity, species richness and the nutrient status of the soil. 


\section{References}

Allen, J. R. (2000). Morphodynamics of Holocene salt marshes: a review sketch from the Atlantic and Southern North Sea coasts of Europe. Quaternary Science Reviews, 19(12), 1155-1231.

Andersen, T. J., Svinth, S., \& Pejrup, M. (2011). Temporal variation of accumulation rates on a natural salt marsh in the 20th century-The impact of sea level rise and increased inundation frequency. Marine Geology, 279(1-4), 178-187.

Balke, T., Lohmus, K., Hillebrand, H., Zielinski, O., Haynert, K., Meier, D., Hodapp, D., Minden, V., \& Kleyer, M. (2017). Experimental salt marsh islands: a model system for novel metacommunity experiments. Estuarine, Coastal and Shelf Science, 198(A), 288-298.

Bakker, J. D., De Leeuw, J., Dijkema, K. S., Leendertse, P. C., Prins, H. T., \& Rozema, J. (1993). Salt marshes along the coast of the Netherlands. NetherlandsWetlands, 73-95.

Bakker, J. P. (2014). Ecology of salt marshes - 40 years of research in the wadden sea. Leeuwarden.

Barckhausen, J. (1969). Entstehung und Entwicklung der Insel Langeoog. Beiträge zur Quartärgeologie und Paläogeographie eines ostfriesischen Küstenabschnittes. Oldenburger Jahrbuch, 68, 239-281.

Beck, M., Riedel, T., Graue, J., Köster, J., Kowalski, N., Wu, C. S., Wegener, G., Lipsewers, Y., Freund, H., Böttcher, M. E., Brumsack, H.-J., Cypionka, H., Rullkötter, J., \& Engelen, B. (2011). Imprint of past and present environmental conditions on microbiology and biogeochemistry of coastal Quaternary sediments. Biogeosciences, 8, 55-68.

Bertness, M. D. (1991). Interspecific interactions among high marsh perennials in a New England salt marsh. Ecology, 72(1), 125-137.

Bertness, M. D., \& Leonard, G. H. (1997). The role of positive interactions in communities: lessons from intertidal habitats. Ecology, 78(7), 1976-1989.

Bockelmann, A. C., Bakker, J. P., Neuhaus, R., \& Lage, J. (2002). The relation between vegetation zonation, elevation and inundation frequency in a Wadden Sea salt marsh. Aquatic Botany, 73(3), 211-221. 
Cannavo, P., \& Michel, J. C. (2013). Peat particle size effects on spatial root distribution, and changes on hydraulic and aeration properties. Scientia Horticulturae, 151, 11-21.

Cloern, J. E. (2001). Our evolving conceptual model of the coastal eutrophication problem. Marine Ecology Progress Series, 210, 223-253.

Darby, F. A., \& Turner, R. E. (2008). Effects of eutrophication on salt marsh root and rhizome biomass accumulation. Marine Ecology Progress Series, 363, 63-70.

De Vlas, J., Mandema, F.S., Nolte, S., Van Klink, R. \& Esselink, P. (2013). Nature conservation of salt marshes - The influence of grazing on biodiversity. Report It Fryske Gea, Olterterp.

Finlayson, C. M., \& Davidson, N. C. (1999). Global review of wetland resources and priorities for wetland inventory. Preface iv Summary Report, 15.

Giani, L., \& Landt, A. (2000). Initiale Marschbodenentwicklung aus brackigen Sedimenten des Dollarts an der südwestlichen Nordseeküste. Journal of Plant Nutrition and Soil Science, 163(5), 549-553.

Gleason, M. L., Elmer, D. A., Pien, N. C., \& Fisher, J. S. (1979). Effects of stem density upon sediment retention by salt marsh cord grass, Spartina alterniflora Loisel. Estuaries, 2(4), 271-273.

Graw, K. (1995). Wellenenergie - eine hydromechanische Analyse. Institut f. Grundbau, Abfall- und Wasserwesen, Bergische Univ., Gesamthochsch. Wuppertal.

Hedges, J. I., \& Oades, J. M. (1997). Comparative organic geochemistries of soils and marine sediments. Organic Geochemistry, 27(7-8), 319-361.

Hemminga, M. A., \& Buth, G. J. C. (1991). Decomposition in salt marsh ecosystems of the SW Netherlands: the effects of biotic and abiotic factors. Vegetatio, 92(1), 73-83.

Hemminga, M. A., De Leeuw, J., de Munek, W., \& Koutstaal, B. P. (1991). Decomposition in estuarine salt marshes: the effect of soil salinity and soil water content. Vegetatio, 94(1), 25-33.

Kathiresan, K., \& Bingham, B. L. (2001). Biology of mangroves and mangrove ecosystems. Advances in Marine Biology, 40, 81-251.

Kiden, P., Denys, L., \& Johnston, P. (2002). Late Quaternary sea-level change and isostatic and tectonic land movements along the Belgian-Dutch North Sea 
coast: geological data and model results. Journal of Quaternary Science, 17(56), 535-546.

Kiehl, K., Esselink, P., \& Bakker, J. P. (1997). Nutrient limitation and plant species composition in temperate salt marshes. Oecologia, 111(3), 325-330.

Kirwan, M. L., Langley, J. A., Guntenspergen, G. R., and Megonigal, J. P. (2013). The impact of sea-level rise on organic matter decay rates in Chesapeake Bay brackish tidal marshes. Biogeosciences, 10, 1869-1876.

Köhn, W. (1991). Die nacheiszeitliche Entwicklung der südlichen Nordsee. Hannoversche Geographische Arbeiten, 45, 1-177.

Kolditz, K., Dellwig, O., Barkowski, J., Bahlo, R., Leipe, T., Freund, H., \& Brumsack, H. J. (2012). Geochemistry of Holocene salt marsh and tidal flat sediments on a barrier island in the southern North Sea (Langeoog, North-west Germany). Sedimentology, 59(2), 337-355.

Kristensen, E., \& Holmer, M. (2001). Decomposition of plant materials in marine sediment exposed to different electron acceptors $\mathrm{CO}_{2}, \mathrm{NO}^{3-}$, and $\left.\mathrm{SO}_{4}{ }^{2-}\right)$, with emphasis on substrate origin, degradation kinetics, and the role of bioturbation. Geochimica et Cosmochimica Acta, 65(3), 419-433.

Lehner, B., \& Döll, P. (2004). Development and validation of a global database of lakes, reservoirs and wetlands. Journal of Hydrology, 296(1-4), 1-22

Levine, J. M., Brewer, J. S., \& Bertness, M. D. (1998). Nutrients, competition and plant zonation in a New England salt marsh. Journal of Ecology, 86(2), 285-292.

Lüders, K. (1953). Die Entstehung der ostfriesischen Inseln und der Einfluss der Dünenbildung auf den geologischen Aufbau der ostfriesischen Küste. Probleme der Küstenforschung im südlichen Nordseegebiet, 5, 5-14.

Mahon, S., \& Carman, K. R. (2008). The influence of salinity on the uptake, distribution, and excretion of metals by the smooth cordgrass, Spartina alterniflora (Loisel.), grown in sediment contaminated by multiple metals. Estuaries and Coasts, 31(6), 1089-109.

Marani, M., Silvestri, S., Belluco, E., Ursino, N., Comerlati, A., Tosatto, O., \& Putti, M. (2006). Spatial organization and ecohydrological interactions in oxygenlimited vegetation ecosystems. Water Resources Research, 42(6).

Nepf, H. M. (1999). Drag, turbulence, and diffusion in flow through emergent vegetation. Water Resources Research, 35(2), 479-489. 
Niesel, V., \& Dietmann, S. (1999). Hydrographic conditions in the backbarrier system of Spiekeroog. The Wadden Sea Ecosystem. Springer-Verlag, 26-30.

Olff, H., De Leeuw, J., Bakker, J. P., Platerink, R. J., \& Van Wijnen, H. J. (1997). Vegetation succession and herbivory in a salt marsh: changes induced by sea level rise and silt deposition along an elevational gradient. Journal of Ecology, 85, 799814.

Pedersen, J. B. T., \& Bartholdy, J. (2006). Budgets for fine-grained sediment in the Danish Wadden Sea. Marine Geology, 235(1-4), 101-117.

Penck, A. (1894). Morphologie der Erdoberfläche, Teil 2. Bibliothek geographischer Handbücher.

Pons, L. J., \& Zonneveld, I. S. (1965). Soil ripening and soil classification: initial soil formation of alluvial deposits with a classification of the resulting soils (No.13). Veenman.

Pott, R. (1995). Farbatlas Nordseeküste und Nordseeinseln. Ulmer, Stuttgart.

Redelstein, R., Dinter, T., Hertel, D., \& Leuschner, C. (2018). Effects of inundation, nutrient availability and plant species diversity on fine root mass and morphology across a saltmarsh flooding gradient. Frontiers in Plant Science, 9, 98.

Reed, D. J. (1995). The response of coastal marshes to sea-level rise: Survival or submergence? Earth Surface Processes and Landforms, 20(1), 39-48.

Reineck, H. E. (1994). Landschaftsgeschichte und Geologie Ostfrieslands. Loga, Köln, 182.

Saintilan, N., Wilson, N. C., Rogers, K., Rajkaran, A., \& Krauss, K. W. (2014). Mangrove expansion and salt marsh decline at mangrove poleward limits. Global Change Biology, 20(1), 147-157.

Schachtschabel, P., Blume, H. P., Brümmer, G., Hartge, K. H., \& Schwertmann, U. (1992). Lehrbuch der Bodenkunde. F. Enke.

Silvertown, J., Lines, C. E., \& Dale, M. P. (1994). Spatial competition between grasses-rates of mutual invasion between four species and the interaction with grazing. Journal of Ecology, 82, 31-38. 
Sleimi, N., \& Abdelly, C. (2003). Salt-tolerance strategy of two halophyte species: Spartina alterniflora and Suaeda fruticosa. Cash Crop Halophytes: Recent Studies. Springer, Dordrecht, 79-85.

Streif, H. J. (1990). Das Ostfriesische Küstengebiet, Inseln, Watten und Marschen. Sammlung Geologischer Führer, 57, 1-376.

Streif, H. (2004). Sedimentary record of Pleistocene and Holocene marine inundations along the North Sea coast of Lower Saxony, Germany. Quaternary International, 112, 3-28.

Vernberg, F. J. (1993). Salt-marsh processes: a review. Environmental Toxicology and Chemistry, 12(12), 2167-2195.

Wolff, W. J., Bakker, J. P., Laursen, K., \& Reise, K. (2010). The Wadden Sea Quality Status Report-Synthesis Report 2010. The Wadden Sea 2010 (Vol. 25). Common Wadden Sea Secretariat (CWSS).

IUSS Working Group WRB (2014). World reference base for soil resources - A framework for international classification, correlation and communication. Rome, Food and Agriculture Organization of the United Nations

Yang, S. L. (1998). The role of Scirpus marsh in attenuation of hydrodynamics and retention of fine sediment in the Yangtze estuary. Estuarine, Coastal and Shelf Science, 47(2), 227-233.

Zedler, J. B., \& Kercher, S. (2005). Wetland resources: status, trends, ecosystem services, and restorability. Annual Review of Environment and Resources, 30, 39-74. 
Chapter 1 


\section{Chapter 2}

\section{Impact of sea level change on coastal soil organic matter, priming effects and prokaryotic community assembly}

Thomas Dinter, Simone Geihser, Matthias Gube, Rolf Daniel, Yakov Kuzyakov

Submitted to FEMS Microbiology Ecology

Author contributions

TD designed and conducted the experiment; TD and SG analysed the data and drafted the manuscript; MG, RD and YK participated in writing the manuscript 


\section{Abstract}

Salt marshes are coastal areas storing high amounts of soil organic matter (SOM) while simultaneously being prone to tidal changes. The priming effect (PE), describing interactions during the decomposition of labile and old SOM, is well examined in terrestrial but not in marine ecosystems. Here, SOM-decomposition and PE were studied under controlled flooding conditions. Soil samples from two salt marsh zones from the Wadden Sea (Germany), the pioneer zone ("Pio"), flooded two times/day and the lower salt marsh zone ("Low"), flooded eight times/month, were exposed to three different inundation-treatments: All-time-ebb ("Ebb"), all-timeflood ("Flood") or temporal flooding ("Tide"). $\mathrm{CO}_{2}$-efflux and prokaryotic community shifts were measured over 56 days. Priming was induced by ${ }^{14} \mathrm{C}$-glucose addition. Soil- $\mathrm{CO}_{2}$-efflux followed "Low">"Pio" and "Tide">"Ebb"> Flood" due to SOM content, $\mathrm{O}_{2}$-depletion and moisture maintenance. PE's in both zones were positive ("Ebb") or absent ("Flood", "Tide") due to different prokaryotic metabolism. Higher prokaryotic biomass induced higher PE in "Low" than in "Pio". 16S-rRNA-gene-amplicon-based analysis revealed differences in bacterial and archaeal community composition between "Pio" and "Low", and temporal niche adaptation in both zones with water level treatments. Strongest alterations were found in "Ebb". Overall, we found a close relationship between inundation frequency, $\mathrm{CO}_{2}$-efflux and prokaryotic community structure.

Keywords: Salt marsh development, Sea level rise, Soil organic matter, Decomposition, Priming effect, Prokaryotic community structure 


\subsection{Introduction}

Salt marshes are complex and dynamic ecosystems at the interface between the marine and terrestrial environment. They are also one of the most vulnerable habitats by human impacts, either directly, e.g. by eutrophication, or indirectly by sea-level rise (Doody, 2007; Peeters \& Peperzak, 1990). Modelling approaches based on IPCC reports estimated a decrease in salt marsh area worldwide by $20-45 \%$ until 2100 due to increasing global sea level (Craft et al., 2009). The balance between organic matter (OM) accumulation and decomposition on salt marshes will be strongly affected by sea level (Kirwan \& Megonigal, 2013; Langley et al., 2009; Reed, 1995). Nevertheless, two opposing theories concerning the impact of flooding onto decomposition can be distinguished: Most studies support the theory that increased flooding duration decreases belowground organic matter decomposition owing to changes from oxic to anoxic conditions or/and increased salinity (Davidson \& Janssens, 2006; Mendelssohn et al., 1999; Miller et al., 2001; Nyman \& DeLaune, 1991). However, recent studies showed that longer flooding duration has minor influence on decomposition rates, because the negative impacts are being compensated to some extent by moisture and nutrient supply for prokaryotes (Kirwan et al., 2013; Mueller et al., 2016).

Although salt marshes store high amounts of carbon (C) (44.6 $\left.\mathrm{Tg} \mathrm{C} \mathrm{a}^{-1}\right)$, most studies concerning a phenomenon called "priming effect" (PE) are restricted to the terrestrial environment and do not include aquatic ecosystems (Bianchi, 2011; Chmura et al., 2003). PE's are 'strong short-term changes in the turnover of soil organic matter caused by comparatively moderate treatments of the soil' (Kuzyakov et al., 2000). These effects can be either positive (i.e. accelerated decomposition of soil organic matter (SOM) after addition of substrate) or negative (i.e. decreased decomposition of SOM after addition). Changing environmental conditions of coastal soils is likely to alter substrate supply and thus affect PE's. It was suggested, but scarcely examined, that PE intensity on the $\mathrm{C}$ cycle in aquatic systems is in the same order of magnitude as in terrestrial ecosystems (Guenet et al., 2010).

An evaluation of possible PE's in salt marsh ecosystems and the effects of tidal inundation, together with the high potential of tidal wetlands to sequester $C$, is the main motivation for this study. Therefore, we sampled soil from two locations of a 
tidal wetland with different inundation frequencies: Soils from the pioneer zone ("Pio") in close proximity to the sea, and soils from the lower salt marsh zone ("Low"), which develop when inundation rate has decreased as a result of higher elevation. We treated "Pio" and "Low" soils with three inundation frequencies of saltwater: $24 \mathrm{~h}$ ebb ("Ebb"), 24h-flood ("Flood") and tides according to the natural rhythm ("Tides"). Labelling with ${ }^{14} \mathrm{C}$-glucose following continuous $\mathrm{CO}_{2}$ and ${ }^{14} \mathrm{CO}_{2}$-efflux measurements enabled to address the five main hypotheses:

1) Mineralisation of added glucose in "Tide" and "Flood" is slowed down by dilution of glucose through the added saltwater and by lower oxygen availability as compared to "Ebb".

2) SOM decomposition in "Pio" is reduced as compared to "Low" due to lower total prokaryotic biomass resulting from harsher environmental conditions (e.g. salt stress) and less $C$ input by plants.

3) Decreasing $\mathrm{CO}_{2}$-efflux rates are expected in the sequence "Ebb" > "Tide" > "Flood" because of hampered diffusion of oxygen during flooding, hence limiting respiration and salt stress from saltwater (see also Cannavo \& Michel, 2013)

4) PE's in "Pio" will be higher compared to "Low" in the "Tide" and "Flood" treatments, because a greater salt stress tolerance of prokaryotes in "Pio" enables an acceleration of added glucose decomposition and SOM under suboptimal conditions. Hence, we expect a slightly negative PE in "Low" by preferential substrate utilisation (Kuzyakov \& Bol, 2006).

5) The three flooding frequencies results in specific prokaryotic community patterns by fast changing habitat conditions (Weise et al., 2016). 


\subsection{Materials and methods}

\section{Site description and field sampling}
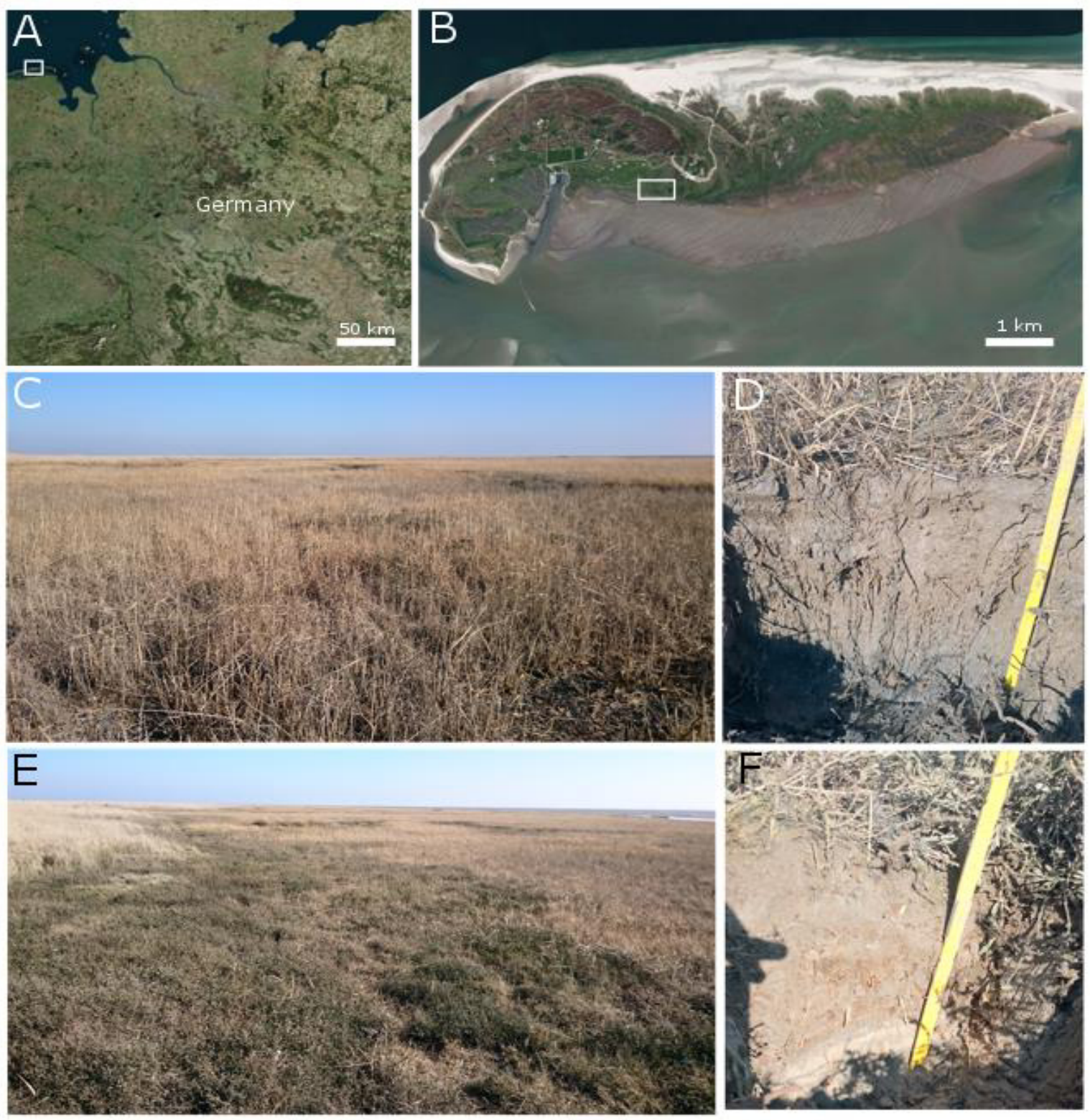

Figure 2.1 A \& B Location of the sampling area in north-western German barrier islands and in salt marshes along Spiekeroog; C "Pio" in top view; D Soil profile of "Pio"; E "Low" in top view; F Profile of "Low"

Sampling was performed at the south side of a barrier island (Spiekeroog) in a temperate salt marsh of the Wadden Sea of Germany $\left(53^{\circ} 45^{\prime} \mathrm{N}, 43^{\circ} 19^{\prime} \mathrm{E}\right)$ in March 2015 during ebb $\left(10^{\circ} \mathrm{C}_{\text {air }}\right)$. Vegetation of the pioneer zone consisted mainly of Suaeda 
Chapter 2

maritima and Spartina anglica, whereas Atriplex portulacoides and Puccinella maritima were dominant in the lower salt marsh zone. Undisturbed soil samples were taken from the upper layer (0-5 cm) of a Salic Fluvisol (WRB, 2014) from "Pio" and "Low" using a soil corer ( $\varnothing 7 \mathrm{~cm}$ ) and transferred in a $250 \mathrm{ml}$ "CombiSart"Filterholder (Sartorius, Germany) in original vertical orientation of the soil column (Figure 2.1). No sieving was done to avoid artificially enhanced mineralisation (Datta et al., 2014).

Table 2.1 Basic characteristics of the Ai/Ah-horizons from "Pio"- and "Low"-soils

\begin{tabular}{|c|c|c|c|c|c|c|c|c|c|}
\hline Soil & $\begin{array}{l}C_{\text {org }} \\
{[\%]}\end{array}$ & $\begin{array}{l}\mathrm{N}_{\mathrm{t}} \\
{[\%]}\end{array}$ & $\mathrm{C} / \mathrm{N}$ & $\overline{\mathrm{pH}}$ & $\begin{array}{l}\mathrm{CaCO}_{3} \\
{[\%]}\end{array}$ & $\begin{array}{l}\text { Sand } \\
63- \\
2000 \mu \mathrm{m}\end{array}$ & $\begin{array}{l}\text { Silt } \\
2-63 \mu \mathrm{m}\end{array}$ & $\begin{array}{l}\text { Clay } \\
<2 \mu \mathrm{m}\end{array}$ & $\begin{array}{l}\mathrm{PB}(\mathrm{CFE})^{1} \\
{\left[\mathrm{mg} \mathrm{C} \mathrm{g}^{-1}\right]}\end{array}$ \\
\hline "Pio" & 3.78 & 0.36 & 10.3 & 7.1 & 1.1 & 26 & 41.2 & 32.8 & 0.20 \\
\hline "Low" & 5.47 & 0.49 & 11.2 & 7.1 & 1.2 & 22.8 & 41.6 & 35.5 & 0.37 \\
\hline
\end{tabular}

1 PB (CFE): Prokaryotic biomass $\mathrm{C}$ derived from chloroform fumigated extraction 


\section{Experimental design}

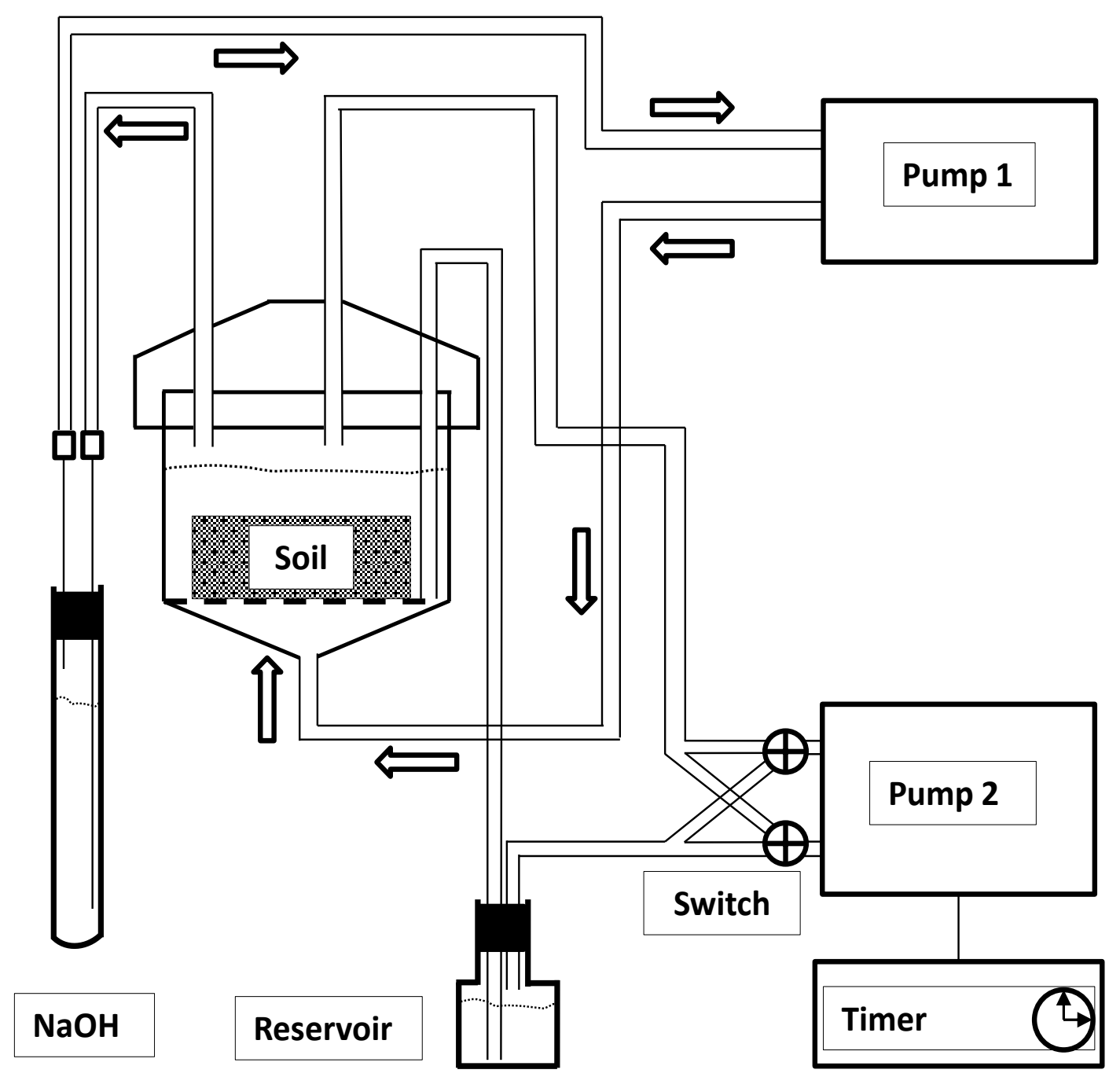

Figure 2.2 Scheme of the experimental equipment for simulation tides. Arrows show the direction of air flow (controlled by Pump 1); center: microcosm with soil core on filter holder (long dashed line below the soil core) and maximum water height in "Flood"- and "Tide"-treatments (dotted line); left: tube with $\mathrm{NaOH}$ solution for $\mathrm{CO}_{2}$ trapping; bottom right: additional circle for "Tide"-treatments containing a secondary pump controlled by an automated timer, a switch to control air flow direction through "Tide"-circle and a salt water reservoir. 
In order to simulate the tidal influence on SOM decomposition, we established a laboratory experiment, in which two soils were exposed to three inundation frequencies. In total, 48 samples from "Pio" and "Low" were preincubated at $20^{\circ} \mathrm{C}$ for 4 weeks until establishment of a stable $\mathrm{CO}_{2}$-efflux under following treatments: For simulation of "Ebb", samples were kept at initial soil moisture from the field. Soil in "Flood"-treatments was constantly covered with $100 \mathrm{ml}$ of artificial seawater containing $\mathrm{NaCl}\left(27.5 \mathrm{~g} \mathrm{l}^{-1}\right), \mathrm{MgCl}_{2} * 6 \mathrm{H}_{2} \mathrm{O}$ (2.44 $\left.\mathrm{gl}^{-1}\right), \mathrm{MgSO}_{4} * 7 \mathrm{H}_{2} \mathrm{O}$ (3.24 $\left.\mathrm{g} \mathrm{l}^{-1}\right)$ and $\mathrm{CaCl}_{2}{ }^{*} 2 \mathrm{H}_{2} \mathrm{O}$ (1.5 $\left.\mathrm{g} \mathrm{l}^{-1}\right)$ (Karius \& Machunze, 2011). Same seawater was used to periodically flood the soils in the third treatment ("Tide") every $12 \mathrm{~h}$ for a period of 6 h. Treatments with constant levels of water, i.e. "Ebb" and "Flood", consist of a microcosm unit, one membrane pump (pump 1) and one flask with $10 \mathrm{ml} \mathrm{NaOH} \mathrm{(1} \mathrm{M)}$ connected via PVC-tubes (Figure 2.2) (see also Kuzyakov \& Siniakina, 2001). All connections were kept airtight unit had three upper outlets and one at the bottom that was supported by a filter holder framed by four layers of perforated polyethylene (0.5 mm). Pump 1 constantly pushed air from the bottom into the microcosm. Evolved $\mathrm{CO}_{2}$ from the soil was carried along by the air stream through the upper outlet into the $\mathrm{NaOH}$-solution for trapping. $\mathrm{CO}_{2}$-free air was sucked out of the headspace through the $\mathrm{NaOH}$-vessel towards Pump 1 closing the circle.

Treatments with changing water levels (i.e. "Tide") had the same design explained above but were connected to a secondary pump (Pump 2), an automatic timer and a flask to store the artificial saltwater. Pump 2 was activated by the automatic timer every 6 hours daily for one minute to push into or to release saltwater from the reservoir to the microcosm by air pressure. To flood the microcosm, Pump 2 increased the air pressure in the sea water reservoir and thereby pushed the water into the upper inlet. Since Pump 1 constantly put pressure onto the lower inlet, no saltwater could reach Pump 1. Moreover, no water could flow back to the reservoir due to a stable pressure ensured by membrane Pump 2. Switching the three-way valve in front of Pump 2 resulted in a reversed circle: Pump 2 then sucked water into the sea water reservoir by simultaneously increasing air pressure inside the microcosm and decreasing in the reservoir. During the whole experiment temperature was kept constant between $21-23^{\circ} \mathrm{C}$. 
The experimental design was focused on mimicking natural conditions in the salt marsh. Strong dilution during tidal cycles as in-situ disadvantage could be avoided using the presented experimental approach. The dominating exchange of water in salt marshes is in vertical directions (Nuttle, 1988). This was considered in the design by a single inlet at the bottom of the microcosm for water exchange (Figure 2.2). We assured constant and comparable quality of the water by using artificial saltwater. In this regard, we excluded stochastically differences in nutrient- and saltconcentrations in natural seawater as factors affecting $\mathrm{CO}_{2}$-efflux and mineralisation. For instance, nutrient ratios have been shown to impact on the balancing between immobilisation and mineralisation (Guenet et al., 2010). Moreover, changes in salinity were found to both positively and negatively correlate with decomposition in salt marsh ecosystems and were therefore excluded in the experimental design (Craft, 2007; Hemminga \& Buth, 1991). With a constant air temperature during the experiment, we avoided temperature-mediated changes in SOM decomposition (Davidson \& Janssens, 2006). Samples were set as intact cores into the microcosms to preserve the initial geochemical and prokaryotic stratification found in salt marsh soils (Froelich et al., 1979; Koretsky et al., 2005). Finally, no sieving was performed to avoid temporal respiration flush due to destruction of soil aggregates and penetration of $\mathrm{O}_{2}$ in deeper soil layers or release of former enclosed nutrients (Datta et al., 2014; Veen \& Kuikman, 1990).

\section{Labelling}

After preincubation, two labelling stock solutions of $150 \mathrm{ml}$ were prepared for both soils containing a label of $20 \mathrm{kBq}$ of ${ }^{14} \mathrm{C}$-Glucose each and $400 \mathrm{mg}$ ("Pio") and $815 \mathrm{mg}$ ("Low") unlabelled D(+)-Glucose. As this corresponds to about double the amount of prokaryotic derived carbon $\left(\mathrm{C}_{\mathrm{p}}\right)$ in "Pio" and "Low" soils, both soils received glucose approximately two times their prokaryotic C content. Each microcosm was labelled separately. Half of the microcosms (i.e. 4*"Pio-Ebb", 4* "Low-Ebb", 4* "Pio-Flood", 4* "Low-Flood", 4* "Pio-Tide" and 4* "Low-Tide") received $10 \mathrm{ml}$ of the corresponding stock solution distributed homogeneously over the soil. "Tide"-treatments were labelled during ebb-cycle with more than three hours remaining in the current tidal 
status. An otherwise identical patch of samples did not receive glucose, and thus served as control for calculation of PE.

\section{Sampling and analyses}

$\mathrm{NaOH}$ was regularly exchanged (i.e. 8 times on the first day after labelling, 2 times on the second day and afterwards in intervals of 1 to 7 days). For measuring ${ }^{14} \mathrm{C}$ activity, $1 \mathrm{ml}$ aliquots of $\mathrm{NaOH}$ were mixed with $8 \mathrm{ml}$ scintillation cocktail Rotizint $\mathrm{Eco}^{+}$(Roth, Germany) and vortexed. ${ }^{14} \mathrm{C}$ activity was determined using a 300 SL automatic liquid scintillation counter (Hidex, Turku, Finland) after decay of chemiluminescence with a counting time of 5 minutes. Remaining $9 \mathrm{ml} \mathrm{NaOH}$ were used for determination of total $\mathrm{CO}_{2}$ with TOC-5050 (Shimadzu, Kyoto, Japan).

At the end of the experiment, aliquots of soils from all treatments were sampled for analysis of prokaryotic biomass (PB) and extractable carbon (EC) by chloroform fumigated extraction (CFE). The same procedure as described above was performed to obtain ${ }^{14} \mathrm{C}$ activity in these compartments. Remaining soil was dried at $105^{\circ} \mathrm{C}$ and ground in a ball mill at $205 \mathrm{U} / \mathrm{min}$ for 5 minutes. Samples were divided to determine ${ }^{14} \mathrm{C}$ activity separately in total inorganic carbon (TIC) and in bulk soil. For TIC, an aliquot of $2 \mathrm{~g}$ soil was put in a closed chamber together with $2 \mathrm{ml}$ of $1 \mathrm{M} \mathrm{NaOH}$. After the addition of $10 \mathrm{ml} \mathrm{HCl}$ (20\%), evolved $\mathrm{CO}_{2}$ was trapped in the $\mathrm{NaOH}$ and measured by liquid scintillation counting. For ${ }^{14} \mathrm{C}$ activity in bulk soil, $1 \mathrm{~g}$ was combusted in automatic oxidizer (Zinsser Analytic OX500, Frankfurt, Germany) and released $\mathrm{CO}_{2}$ was trapped in Oxysolve $\mathrm{C} 400$ (Zinsser Analytic) scintillation liquid. The artificial saltwater was filtrated, mixed 1:10 with Rotizint $\mathrm{Eco}^{+}$and measured for ${ }^{14} \mathrm{C}$ by liquid scintillation counting (Perkin Elmer Tri-Carb 3180 TR/SL, Massachusetts, USA). 


\section{Amplification of $16 S$ rRNA and high throughput sequencing}

DNA was extracted from soil samples using the MoBio Biofilm DNA extraction kit (MO BIO Laboratories. Carlsbad. USA). Nucleic acids were eluted with Diethylpyrocarbonate (DEPC) treated water. To assess the bacterial diversity, the V3V4 region of the bacterial 16S rRNA was amplified by polymerase chain reaction (PCR) with the following primer set (MiSeq adaptor underlined): 341f (5'-TCGTCGGC AGCGTCAGATGTGTATAAGAGACAGCCTACGGGNGGCWGCWGCAG-3') and 785r (5'GTCTCGTGGGCTCGGAGATGTGTATAAGAGACAGGACTACHVGGGTATCTAA TCC-3'). The PCR reaction mix (25 $\mu \mathrm{l}$ ) contained $10 \mu \mathrm{l}$ of 5 -fold Phusion HF buffer (Finnzymes. Vantaa. Finland), $400 \mu \mathrm{M}$ of each of the four deoxynucleoside triphosphates, $20 \mu \mathrm{M}$ of each primer, $75 \mathrm{mM} \mathrm{MgCl}$, 2.5\% Dimethylsulfoxid (DMSO), $0.5 \mathrm{U}$ of Phusion High Fidelity Hot Start DNA polymerase (Finnzymes) and approximately $25 \mathrm{ng}$ of DNA. The following thermal cycling conditions were used for amplification: Initial denaturation at $98^{\circ} \mathrm{C}$ for $30 \mathrm{~s}$ and 30 cycles of $10 \mathrm{~s}$ at $98^{\circ} \mathrm{C}, 30 \mathrm{~s}$ at $60^{\circ} \mathrm{C}$ and $30 \mathrm{~s}$ at $72^{\circ} \mathrm{C}$. The final extension was carried out at $72^{\circ} \mathrm{C}$ for $2 \mathrm{~min}$. To assess the archaeal diversity, the V4V5 region of the archaeal 16S rRNA was amplified with the primer set Arch forward primer (Miseq adapter sequence underlined) 5'TCGTCGGCAGCGTCAGATGTGTATAAGAGACAGGGTGBCAGCCGCCGCGGTAA-3' and Archaea reverse primer 5'- GTCTCGTGGGCTCGGAGATGTGTATAAGAGACA GCCCGCCAATTYCTTTAAG-3'. The PCR reaction mix (25 $\mu \mathrm{l})$ contained $5 \mu \mathrm{l}$ of 5 -fold Phusion GC buffer (Finnzymes. Vantaa. Finland), $200 \mu \mathrm{M}$ of each of the four deoxynucleoside triphosphates, $10 \mu \mathrm{M}$ of each primer, $1.5 \mathrm{mM} \mathrm{MgCl}_{2}$. 2.5\% DMSO, $0.25 \mathrm{U}$ of Phusion High Fidelity Hot Start DNA polymerase (Finnzymes) and approximately $20 \mathrm{ng}$ of DNA. The following thermal cycling conditions were used: Initial denaturation at $98^{\circ} \mathrm{C}$ for $30 \mathrm{~s}$ and 10 cycles of $10 \mathrm{~s}$ at $98^{\circ} \mathrm{C}, 30 \mathrm{~s}$ at $63^{\circ} \mathrm{C}$ and 15 $\mathrm{s}$ at $72^{\circ} \mathrm{C}$. The final extension was carried out at $72^{\circ} \mathrm{C}$ for $2 \mathrm{~min}$. The initial annealing temperature of $63^{\circ} \mathrm{C}$ was reduced by $1^{\circ} \mathrm{C}$ per cycle for the next 10 cycles and maintained at the final annealing temperature of $53^{\circ} \mathrm{C}$ for the remaining 20 cycles. Three independent PCR reactions were performed per sample. Obtained PCR products were controlled for appropriate size, pooled in equal amounts and purified using the GeneRead size selection kit (Qiagen) with one difference to the recommendation of the manufacturer: a two-step elution was done with addition of 
$14 \mu \mathrm{l}$ DEPC-treated water to the column, short incubation and centrifugation. Afterwards, these steps were repeated with $14 \mu \mathrm{l}$ of the included elution buffer. Both liquids were previously heated to $30^{\circ} \mathrm{C}$. Quantification of the PCR products was performed using the Quant-iT dsDNA HS assay kit and a Qubit fluorometer (Invitrogen ${ }^{\mathrm{TM}}$ ). The Göttingen Genomics Laboratory determined the 16S rRNA gene sequences using an Illumina MiSeq Sequencer and the MiSeq Reagent Kit v3 (Illumina, San Diego. USA).

Generated 16S rRNA gene and rRNA transcripts were processed with USEARCH version 8.0.1623 (Edgar et al., 2011; Quast et al., 2012) as follows: Pairedend reads were merged, quality-filtered reads shorter than 400 bp removed. Processed sequences of all samples were joined and clustered in operational taxonomic units (OTUs) at 3\% genetic divergence using the UPARSE algorithm implemented in USEARCH (Edgar, 2013). A de novo (abundance-based) chimera removal was included in the clustering step. Subsequently, remaining chimeric sequences were removed using UCHIME in reference mode with the most recent SILVA database (Silva SSURef 123 NR 99) as reference data set (Camacho et al., 2009; Edgar, 2013; Quast et al., 2012). Processed sequences were mapped on OTU sequences to determine the occurrence and abundance of each OTU. To determine taxonomy, the representative sequence of each OTU was classified by BLAST alignment against the most recent SILVA database (see above). All non-bacterial and non-archaeal OTUs were removed from the respective data set. Alpha diversity indices and rarefaction curves were calculated with QIIME version 1.9 (Wemheuer et al., 2014). Sequence data was deposited in the Sequence Read Archive (SRA) of the National Center for Biotechnology Information (NCBI) under the accession number "SRP126382". 


\section{Calculations and statistics}

Amount of total $\mathrm{CO}_{2}\left(\mu \mathrm{g} \mathrm{g}_{\mathrm{soil}}{ }^{-1}\right)$ released from soil was calculated as:

$$
\mathrm{CO}_{2} \text { Total }=\mathrm{CO}_{2 \mathrm{NaOH}} * 10 / \text { SoildW }
$$

with $\mathrm{CO}_{2}$ in $\mathrm{NaOH}$-trap as $\mathrm{CO}_{2} \mathrm{NaOH}(\mathrm{ppm})$ and Soildw (g) as dry weight of the soil (equation 2.1). ${ }^{14} \mathrm{C}$ activity $\left({ }^{14} \mathrm{C}_{\mathrm{abs}}\right.$ (DPM)) was obtained by subtracting ${ }^{14} \mathrm{C}$ signal of unlabelled samples $\left({ }^{14} \mathrm{C}\right.$ unlabelled (DPM)) from labelled samples $\left({ }^{14}\right.$ Clabelled (DPM)) (equation 2.2):

$$
{ }^{14} \mathrm{C} \text { abs }={ }^{14} \mathrm{Cun}_{\text {labelled }}{ }^{14} \mathrm{C} \text { labelled }
$$

With the added known ${ }^{14} \mathrm{C}$-activity, percentage of ${ }^{14} \mathrm{C}$-glucose was estimated from decays per minute (dpm) for each time interval. By calculation of glucose-derived $\mathrm{CO}_{2}$, PE was then calculated as (equation 2.3):

$$
\mathrm{PE}=\mathrm{CO}_{2} \text { Total }-\mathrm{CO}_{2} \text { unlabelled }-\mathrm{CO}_{2} \text { glucose }
$$

with $\mathrm{CO}_{2}$ Total $(\mu \mathrm{g})$ as $\mathrm{CO}_{2}$ from labelled treatments, $\mathrm{CO}_{2}$ unlabelled $(\mu \mathrm{g})$ from unlabelled treatments and $\mathrm{CO}_{2}$ glucose $(\mu \mathrm{g})$ calculated from scintillation counting.

Since distributions of residuals violated assumption of normality, KruskalWallis-Tests were used to test effects of soil origin ("Pio" and "Low"), water level ("Ebb", "Flood", "Tide") and glucose addition onto $\mathrm{CO}_{2}$-efflux and PE. In case of significant results, pairwise comparisons were carried out with Mann-Whitney-U tests. For amplicon-based analysis, possible correlations between the sampling points, and bacterial or archeal richness (number of OTUs) as well as Shannon indices, abundance, and gene expression were determined employing the nonparametric Wilcoxon rank-sum test (Gifford et al., 2013).

All statistical analyses were conducted employing $\mathrm{R}$ (version 3.1.2; $\mathrm{R}$ Development Core Team 2014 [http://www.R-project.org/]). Correlations were considered as significant with $\mathrm{p} \leq 0.05$. Permutational multivariate analysis of variance (PerMANOVA) was performed with 9,999 permutations to test for significant correlations between community structure and flooding frequency as well 
as glucose addition. Correlation indices analysis was performed by multilevel pattern analysis in $\mathrm{R}$ with subsampled datasets, due to high diverse sequence numbers between the samples. The dataset of bacterial lower salt marsh "Tide" treatment was thereby excluded from further analysis because of low sequence numbers. A positive preference of a species for a treatment is expressed by significant values for a species prevailing within a site belonging to the site group combination compared to the remaining site.

\subsection{Results}

\section{$\mathrm{CO}_{2}$-efflux rates and cumulative $\mathrm{CO}_{2}$-efflux}

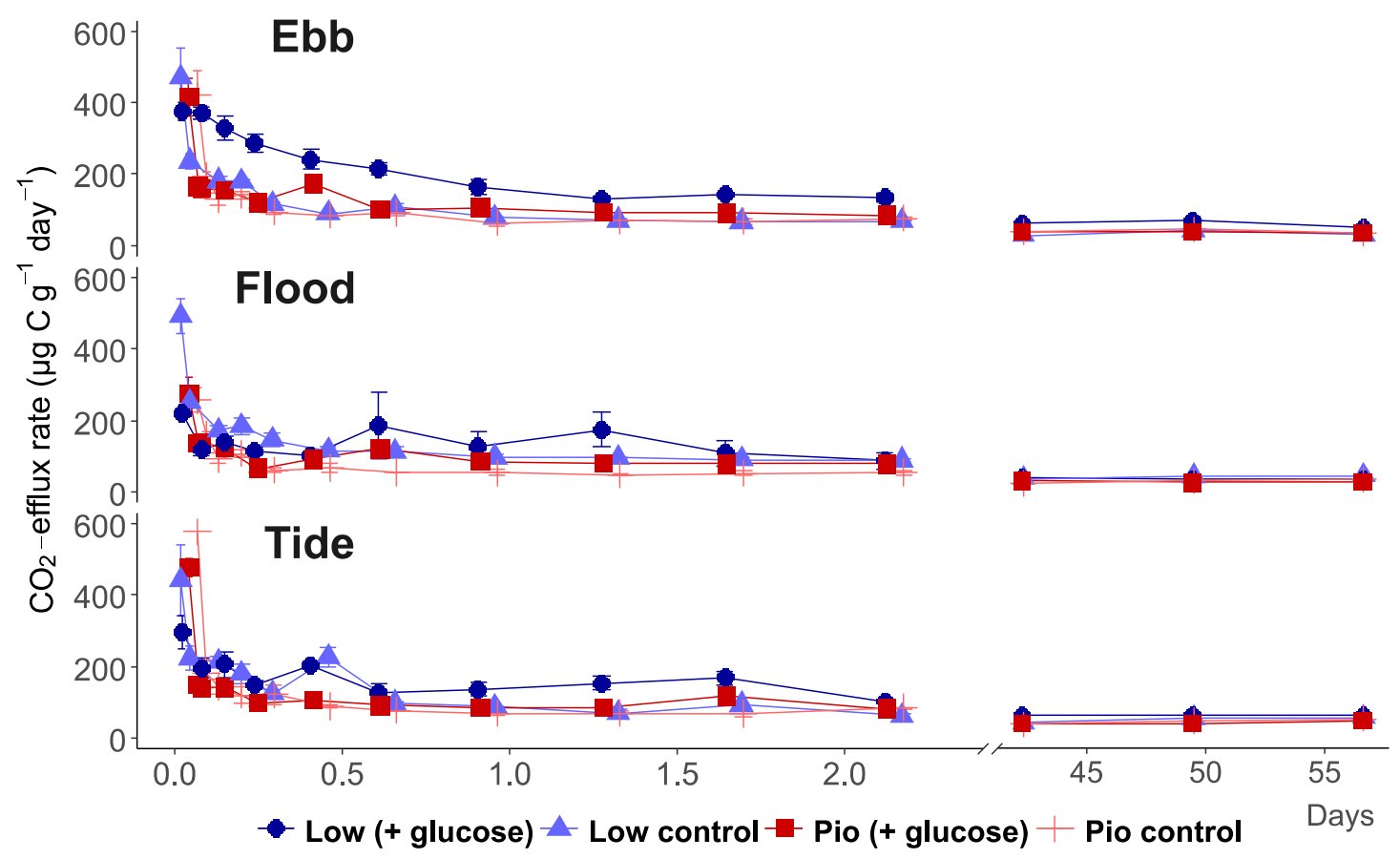

Figure $2.3 \mathrm{CO}_{2}$-efflux rate from both "Pio" and "Low" soils at three water levels: "Ebb", "Flood" and "Tide". Error bars indicate standard errors of the mean.

Total $\mathrm{CO}_{2}$-efflux rates were highest during first 24 hours after labelling in all three water level treatments (i.e. "Ebb", "Flood" and "Tide") (Figure 2.3). During the first day, $\mathrm{CO}_{2}$-efflux depended on soil origin $(\mathrm{p}<0.001)$ and water level $(\mathrm{p}<0.001)$. "Low" showed $22 \pm 3 \%$ higher $\mathrm{CO}_{2}$-efflux rates than "Pio". Between water levels, post-hoc testing indicated significant differences between "Ebb" and "Flood" ( $p<0.001)$ and between "Tide" and "Flood" ( $\mathrm{p}<0.05$ ). From day 2 to 10, $\mathrm{CO}_{2}$-efflux was affected by 
soil origin and glucose addition. "Low" was $21 \pm 5.5 \%$ higher than "Pio". Addition of glucose increased $\mathrm{CO}_{2}$-efflux by $23 \pm 5.4 \%$ on average. Soil origin and water level were also determining factors on $\mathrm{CO}_{2}$-efflux rate during days 11 to 56 . "Low" had a $20.7 \pm 2.4 \%$ higher efflux rate than "Pio". All three water levels were significantly different from each other with "Tide" accounting for $10 \pm 3.0 \%$ higher $\mathrm{CO}_{2}$-efflux rate than "Ebb". Lowest efflux was measured "Flood" with $-26.5 \pm 2.9 \%$ in comparison to "Ebb".

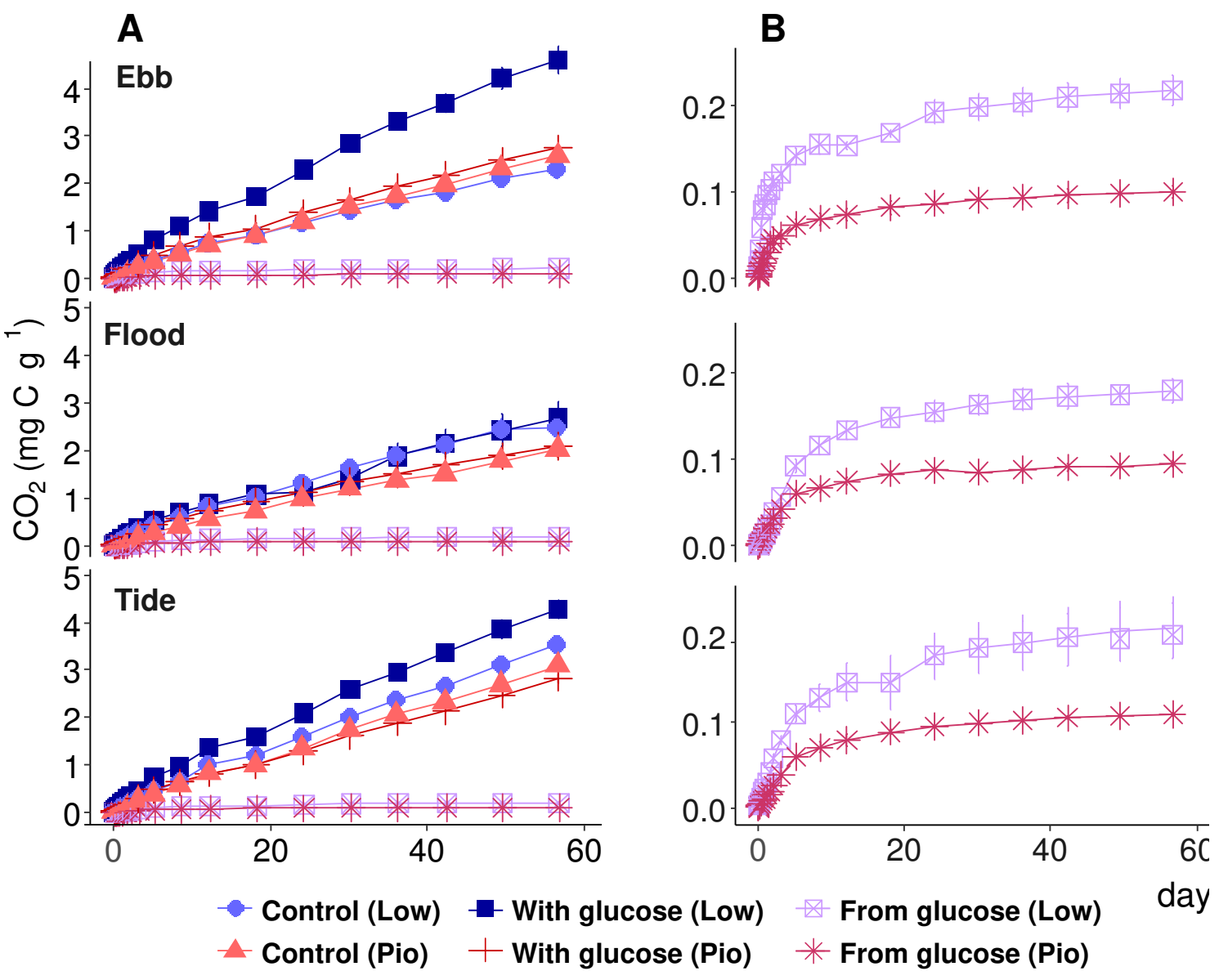

Figure 2.4 A Cumulative $\mathrm{CO}_{2}$-efflux from both soils ("Pio" and "Low") and three water levels ("Ebb", "Flood" and "Tide"). Cumulative $\mathrm{CO}_{2}$-efflux from glucose (based on ${ }^{14} \mathrm{CO}_{2}$ ) is shown in B separated for both soils. Error bars indicate standard errors of the mean.

"Low" soils amended with glucose were always highest in cumulative $\mathrm{CO}_{2}$-efflux across all time periods (Figure 2.4A). However, "Low"-soils without glucose were lowest in "Ebb"-treatments with $50.5 \pm 2.9 \%$ after 56 days. Under all-time-flooded conditions, addition of glucose did not affect $\mathrm{CO}_{2}$ flux from both soils, but "Low" had higher cumulative $\mathrm{CO}_{2}$-efflux than "Pio". After 30 days, "Low" was constantly higher 


\begin{abstract}
under "Tide" conditions
than "Pio" (+24 $\pm 3.7 \%)$.

Mineralisation

of

glucose was higher in

"Low" than in "Pio" soils

in all treatments ("Ebb",

"Flood" and "Tide")

(Figure 2.4B). Largest

difference in total

glucose derived $\mathrm{CO}_{2}$

between "Pio" and

"Low" was found in

"Ebb" with a relative

difference of $+65 \pm 2.3 \%$.

Priming effects (PE)

On the day 1 , neither soil origin nor water level contributed to

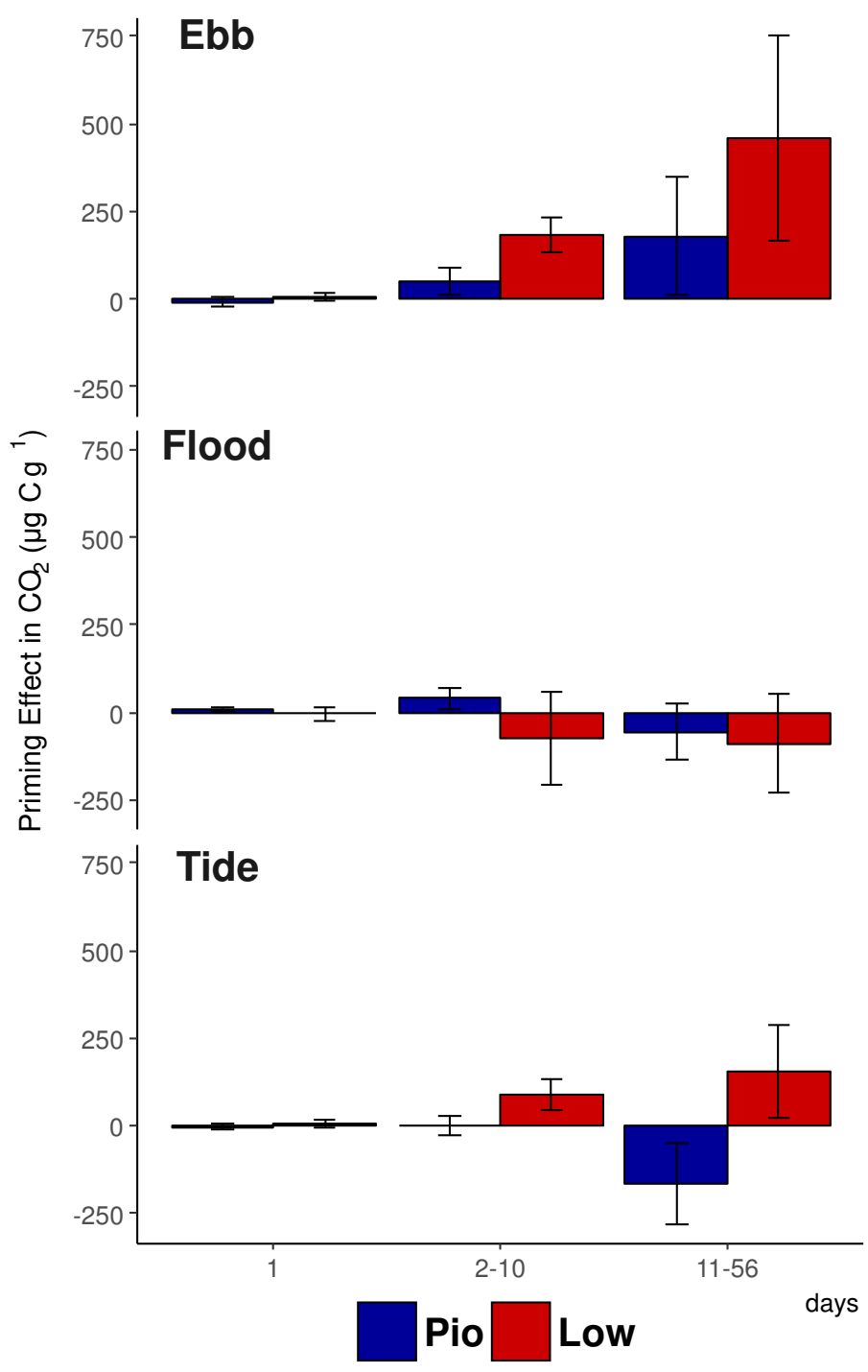

significant PE's. In the

second phase (days 2-

10), "Low" showed a

positive PE under all-

Figure 2.5 PE depending on the water levels ("Ebb", "Flood", "Tide") separated in both soil locations ("Low", "Pio") at three time periods (Day 1, days 2-10, days 11-56).

time "Ebb" as well as

under "Tide" conditions. Under "Ebb"-and "Tide" conditions, sampling location "Low" was significantly higher in PE than "Pio" $(\mathrm{p}<0.05)$. PE's in "Flood" were variable without a distinct positive or negative response. During the long-term phase (Days 11 to 56), PE's were positive for both soil origins under "Ebb" conditions with "Low" showing a 72\% higher PE than "Pio". However, during this period, flooding had still no significant effect on PE with "Pio" and "Low" showing no significant positive or negative PE. Temporal flooding (i.e. "Tide") induced positive PE for "Low" soils and
\end{abstract}


negative PE for "Pio" soils. Regarding time steps 2-10 and 11-56, "Ebb" was the only treatment with a clear positive PE.

\section{Prokaryotic community structures}

Total bacterial and archaeal community structures assessed by amplicon-based $16 \mathrm{~S}$ rRNA gene analyses resulted in 542,583 bacterial and 702,331 archaeal high-quality sequences from all 16 samples taken before and after the experiment. Investigated were the samples from the natural sampling site, serving as reference, as well as the samples incubated under the different water levels after 56 days.

Classification of the obtained $16 \mathrm{~S}$ rRNA sequences revealed differences in the prokaryotic community structures between the reference soil sampling locations pioneer zone and lower salt marsh (Table 2.2). Common in both bacterial communities was that they were dominated by Proteobacteria. Of these, Gamma-, Alpha- and Deltaproteobacteria formed the largest fractions. Further abundant bacterial phyla were Planctomycetes, Actinobacteria, Bacteriodetes, Verrucomicrobia, Chloroflexi and Acidobacteria. Other phyla typically associated with marine sediments, such as Firmicutes, Gemmatimonadetes, Parcubacteria, Lentisphaerae and Cyanobacteria, occurred with abundances below 1\%. Natural bacterial community composition in "Low" showed a different community structure on phylum level compared to "Pio": Actinobacteria, Chloroflexi, and Verrucomicrobia were more abundant in the lower salt marsh. Planctomycetes were almost twice as abundant as in "Pio". In contrast, Bacteriodetes, Firmicutes, Gamma- and Deltaproteobacteria were found to be more abundant in "Pio". 
Table 2.2 Bacterial and archaeal community composition in the reference soils of the pioneer zone and lower salt marsh zone. Indicated is the amount of the most abundant phyla (in bold) and their respective most abundant families on the total prokaryotic community.

\begin{tabular}{|c|c|c|c|}
\hline Phylum & Order & Pioneer zone & $\begin{array}{l}\text { Lower salt } \\
\text { marsh }\end{array}$ \\
\hline \multicolumn{4}{|c|}{ BACTERIA } \\
\hline \multirow[t]{2}{*}{ Actinobacteria } & Total & $14.1 \%$ & $19.5 \%$ \\
\hline & Acidimicrobiales & $11.5 \%$ & $13.9 \%$ \\
\hline \multirow[t]{2}{*}{ Bacteriodetes } & Total & $12.5 \%$ & $3.7 \%$ \\
\hline & Flavobacteriales & $8.3 \%$ & $1.2 \%$ \\
\hline \multirow{2}{*}{ Firmicutes } & Total & $0.6 \%$ & $0.2 \%$ \\
\hline & Clostridiales & $0.5 \%$ & $0.1 \%$ \\
\hline \multirow[t]{2}{*}{ Planctomycetes } & Total & $16.9 \%$ & $32.9 \%$ \\
\hline & Planctomycetales & $14.6 \%$ & $29.0 \%$ \\
\hline \multirow[t]{4}{*}{ Alphaproteobacteria } & Total & $12.7 \%$ & $13.7 \%$ \\
\hline & Rhizobiales & $3.3 \%$ & $4.2 \%$ \\
\hline & Rhodobacterales & $6.9 \%$ & $4.2 \%$ \\
\hline & Rhodospirillales & $1.2 \%$ & $4.8 \%$ \\
\hline \multirow{3}{*}{ Gammaproteobacteria } & Total & $8.0 \%$ & $4.3 \%$ \\
\hline & Cellvibrionales & $4.5 \%$ & $2.8 \%$ \\
\hline & Xanthomonadales & $4.2 \%$ & $1.7 \%$ \\
\hline \multirow[t]{4}{*}{ Deltaproteobacteria } & Total & $16.5 \%$ & $8.1 \%$ \\
\hline & Desulfobacterales & $4.0 \%$ & $0.6 \%$ \\
\hline & Desulfuromonadales & $1.7 \%$ & $0.8 \%$ \\
\hline & Myxococcales & $1.7 \%$ & $1.9 \%$ \\
\hline \multirow[t]{2}{*}{ Verrucomicrobia } & Total & $11.0 \%$ & $6.4 \%$ \\
\hline & Verrucomicrobiales & $10.2 \%$ & $5.9 \%$ \\
\hline Other bacteria & Total & $5.0 \%$ & $6.3 \%$ \\
\hline \multicolumn{4}{|c|}{ ARCHAEA } \\
\hline \multirow[t]{3}{*}{ Euryarchaeota } & Total & $5.0 \%$ & $0.4 \%$ \\
\hline & Methanomicrobiales & $2.1 \%$ & $0.1 \%$ \\
\hline & Methanosarcinales & $2.4 \%$ & $0.1 \%$ \\
\hline Miscellaneous & Total & $0.8 \%$ & $0.1 \%$ \\
\hline Crenarchaeotic Group & Uncultured archaeon & $0.6 \%$ & $0.1 \%$ \\
\hline \multirow[t]{3}{*}{ Thaumarchaeota } & Total & $82.3 \%$ & $97.7 \%$ \\
\hline & $\begin{array}{l}\text { Uncultured Order Marine } \\
\text { Group I }\end{array}$ & $1.4 \%$ & $0.2 \%$ \\
\hline & $\begin{array}{l}\text { Uncultured Order Marine } \\
\text { Group I }\end{array}$ & $78.5 \%$ & $57.4 \%$ \\
\hline Other archaea & Total & $11.9 \%$ & $1.8 \%$ \\
\hline
\end{tabular}


Archaeal community structures in both reference soil sampling locations were dominated by Thaumarchaeota (Table 2.2). Most of the sequences belonging to this phylum were further affiliated to the Marine Group I and the Soil Crenarchaeotic Group. Other abundant detected phyla were Euryarchaeota and members of the Miscellaneous Crenarchaeotic Group (MCG). The archaeal community composition in the lower salt marsh reference soil consisted almost exclusively of Thaumarchaeota of the Marine Group I and the Soil Crenarchaeotic Group. In contrast, the amount of Thaumarcheota in "Pio" was slightly lower and consisted mainly of members of the Marine Group I. Additionally, the archaeal community composition in "Pio" consisted of appreciable amounts of Woesearchaeota and Euryarchaeota as compared to the reference-"Low".

\section{Influence of water level treatments and soil origin on community} composition

In the present study, the long-term effects of water level treatment, soil sampling location and glucose addition on bacterial and archaeal communities were analysed by amplicon-based analysis of the $16 \mathrm{~S}$ rRNA genes. Samples were taken only at the end of the experiment to avoid disturbances in the C-determination. We found no statistically significant effects of added glucose on bacterial or archaeal community composition following to glucose addition, contrasting to the effects seen on total $\mathrm{CO}_{2}$-efflux rates and cumulative $\mathrm{CO}_{2}$-efflux. However, the water level treatment $\left(\mathrm{p}<0.01, \mathrm{r}^{2}=0.108\right)$ as well as the soil sampling location $\left(\mathrm{p}=0.05, \mathrm{r}^{2}=0.108\right)$ were found to influence the prokaryotic community composition significantly. The impact of water level treatment and soil sampling location on variance of bacterial community composition data increased about one third when combining the two treatment types in a two-way PerMANOVA $\left(\mathrm{p}<0.01, \mathrm{r}^{2}=0.339\right)$. Both treatments (water level: $\mathrm{p}=0.037, \mathrm{r}^{2}=0.192$; soil sampling location: $p=0.029, \mathrm{r}^{2}=0.114$ ) also influenced archaeal community composition significantly, and the effect again was significantly higher when both were combined in a two-way PerMANOVA $(\mathrm{p}<0.01$, $\left.r^{2}=0.411\right)$. The statistical significant effects of soil sampling location and water level treatment were analysed with respect to their influence on the most abundant archaeal (Figure 2.6) and bacterial (Figure 2.7) phyla and order. 


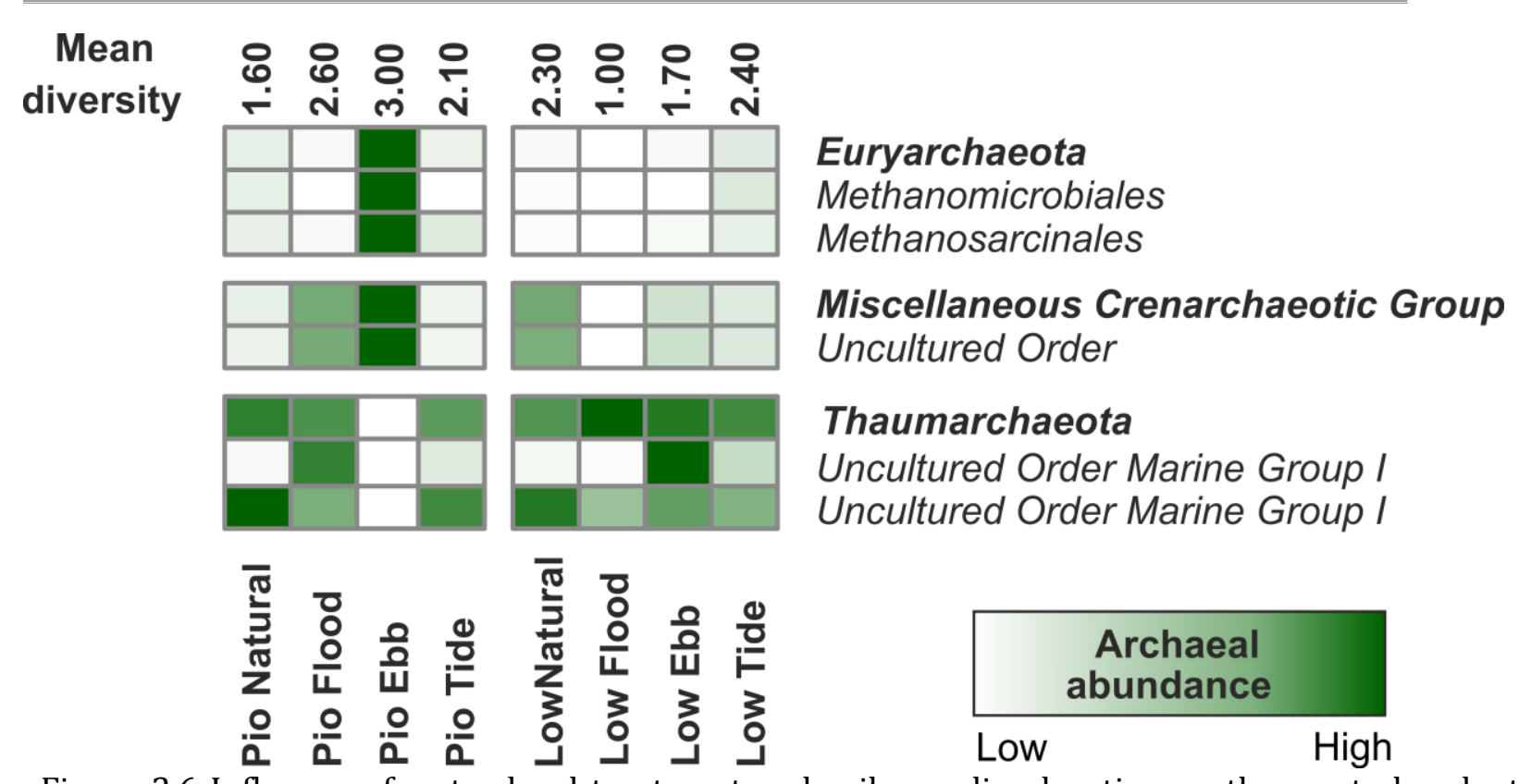

Figure 2.6 Influence of water level treatment and soil sampling location on the most abundant archaeal phyla and their respective most abundant order. The heatmap was created based on a subsampled dataset. Increasing abundance under water level treatment is indicated by increasing colour intensity. Tested treatments are soil sampling location (natural soil from pioneer zone respective lower salt marsh) and the water level treatments "Flood", "Ebb" and "Tide". Shannon indices archaea are given as "Mean diversity" above the respective treatment.

Additionally, mean diversities (Shannon indices) based on the subsampled datasets of archaea and bacteria were included. Analysis of the subsampled datasets revealed that the mean diversity of bacteria is higher than of archaea. The bacterial diversity between the natural references and applied water level treatments were found to be in a similar range. However, the archaeal diversity was in average higher in "Pio" than in "Low". Relative abundances in the prokaryotic community composition changed following the water level as compared to the reference sample. In the "Pio-Ebb" treatment strong changes in bacterial as well as archaeal abundance were determined. Archaea related to Euryarchaeota and the Miscellaneous Crenarchaeotic Group strongly increased in their abundance under "Pio-Ebb" treatment, while Thaumarchaeota strongly decreased. Natural archaeal abundance in both sampling locations was most appropriately reflected by "Flood" treatment. However, certain prokaryotes were found to follow different patterns under the same water level treatments in different soil sampling locations. For instance, a strong influence of water level treatment was visible for the Bacteroidetes, which decreased in "Pio", but slightly increased in "Low" in comparison to the reference samples. 


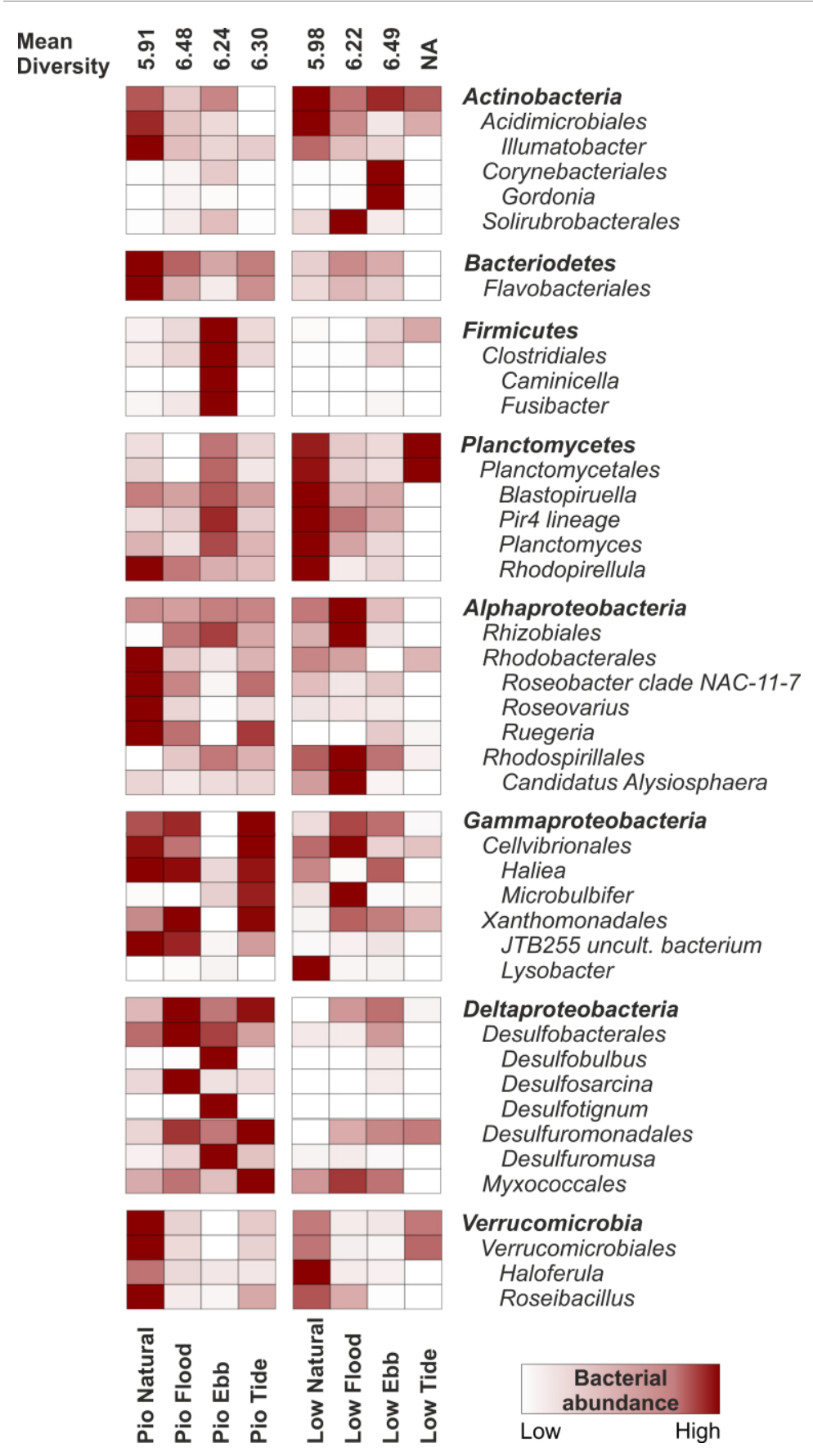

Figure 2.7 Influence of water level treatment and soil origin on the most abundant bacterial and archaeal phyla and their respective most abundant order. The heatmap was created based on a subsampled dataset. Increase in prokaryotic abundance under water level treatment is indicated by increasing colour intensity. Tested treatments are soil sampling location (natural soil from pioneer zone respective lower salt marsh) and the water level treatments "Flood", "Ebb" and "Tide". Shannon indices of bacteria and archaea are given as "Mean diversity" above the respective treatment. 


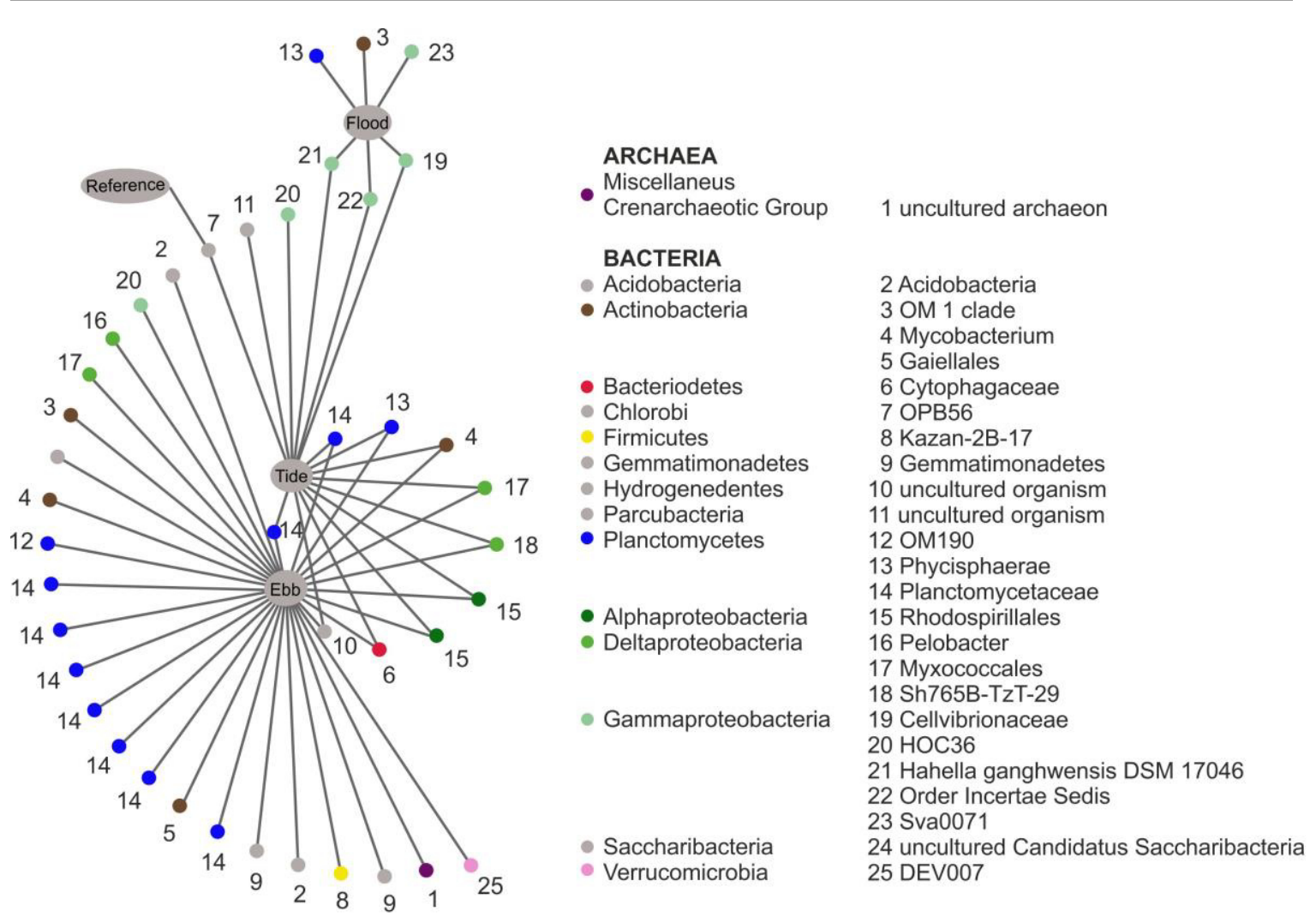

Figure 2.8 Circular association network of prokaryotic indicator species associated to water level treatments and reference samples. The lowest described taxonomic level and the phylum of the detected indicator species is given. High abundant phyla of the dataset are associated to a colour. Stroke length reflects the strength of association to the respective treatments. The network is based on point-biserial calculations of the OTU list. Data of "Tide" treated lower salt marsh samples were excluded.

Based on the calculated most abundant prokaryotic order, associations between treated and reference samples were calculated by multilevel pattern analysis to gain information about possible niche adaptations. Point-biserial coefficients were calculated for bacteria and archaea, whereupon associations to the different water level treatments and reference samples were detected. This correlation estimates the coherence between one dichotomous and one continuous variable. The correlation is based on a subsampled dataset. Significantly $(p<0.05)$ correlated species were visualised in a network with the network analysis tool Cytoscape (Figure 2.8). The lowest described taxonomic level of the identified indicator species and its phylum were given. A colour code was associated just to the most abundant phyla of the whole dataset (Table 2.2). Unique as well as treatment-shared bacterial indicator species were found between "Tide" and "Ebb", "Tide" and Flood" and "Tide" and reference samples. Most unique indicator species were found for "Ebb". Nine indicator species belonged to Planctomycetaceae of Planctomycetes and 
characterised either "Ebb" or both "Ebb" and "Tide", while a single indicator within Phycisphaeraceae of Planctomycetes was indicative for the "Flood" treatment". All five strictly anaerobic indicator species characterised either "Ebb", "Tide" or reference samples, or are shared between them. Additionally, one archaeal indicator belonging to Miscellaneous Crenarchaeotic Group was found for "Ebb".

\subsection{Discussion}

\section{$\mathrm{CO}_{2}$-efflux}

The results of $\mathrm{CO}_{2}$-efflux show a clear relationship between inundation frequency and soil origin: Overall, flooded soils reveal a hampered decomposition mostly due to reduced oxygen-diffusion into the bulk soil by separation gas filled pores from the atmosphere (Davidson \& Janssens, 2006). Oxygen limitation in peatland soils minimize the activity of enzymes (i.e. phenol oxidase) and hence hamper mineralisation of SOM to $\mathrm{CO}_{2}$ (Freeman et al., 2001). The result is an overall lower long-term $\mathrm{CO}_{2}$-efflux under flooded conditions. The negative correlation between inundation frequency and belowground decomposition was also described for natural salt marsh ecosystems (Miller et al., 2001; Nyman \& DeLaune, 1991). It is also expressed in the slower mineralisation in "Tide" compared to pure "Ebb" and matches our third hypothesis. Other studies (Kirwan et al., 2013; Mueller et al., 2016) did not show a clear relationship between SOM decomposition in tidal wetland systems and flooding duration. Temporary flooding can promote decomposition on the surface because of moisture maintenance for enhanced prokaryotic and fungal colonisation (Kirwan et al., 2013; Mendelssohn et al., 1999). This is shown in the longterm (11-56 days) higher $\mathrm{CO}_{2}$-efflux in "Tide"-treatments in comparison to pure "Ebb"-treatments (Figure 2.4), since moisture conditions are expected to be optimal under "Tide" conditions.

Overall, higher $\mathrm{CO}_{2}$-efflux of "Low" compared to "Pio" in all three tidal treatments can partly be assigned to a two times larger prokaryotic biomass content in "Low" compared to "Pio" (Table 2.1) which also supports our second hypothesis. The lower total $\mathrm{CO}_{2}$-efflux and in most cases the minor or negative PE in "Flood" can 
be explained by a reduced energy release within sub- and anaerobic decomposition compared to decomposition in aerobic environments. While diffusion of $\mathrm{O}_{2}$ in "Flood" is restricted by the overlying water column, other terminal electron acceptors (e.g. $\mathrm{NO}^{3-}, \mathrm{SO}_{4}{ }^{2-}$ ) are being used by prokaryotes. These alternative acceptors do not allow as much energy yield as oxygen and hence this results in decreased prokaryotic growth. Moreover, lower $\mathrm{CO}_{2}$-concentrations in "Flood" are partially caused by the type of $\mathrm{CO}_{2}$ trapping: During all time flooding, products from decomposition reactions are different than in well drained soils (Ponnamperuma, 1972) and therefore, a small contribution of methane in purely flooded soils (which was not trapped in the $\mathrm{NaOH}$ ) could be expected via methanogenesis (Bartlett \& Harriss, 1993).

\section{Priming Effects (PE)}

The absence of PE at day 1 can be explained by usage of added labile carbon for fast prokaryotic growth (Catalán et al., 2015; Guenet et al., 2010). With exception of the first day, PE was always higher in "Ebb" compared to "Flood" or "Tide". Differences in prokaryotic weighting between anabolism and catabolism between the former and the latter could explain this discrepancy: In aqueous mediums (i.e. "Flood" and "Tide"), energy from labile carbon pulses (like glucose) might be invested directly into growth and biomass rather than into production of extracellular enzymes, being a strategy in more structurally stable environments to endure carbon shortage (i.e. "Ebb") (Catalán et al., 2015; Jobbágy \& Jackson, 2001). Regarding the absence of clear PE in the all-time-flood conditions, one must consider also a dilution factor of added glucose within the surrounding seawater as expected in our first hypothesis. Another explanation are the more stable conditions in "Ebb": Prokaryotes are hampered to switch from an easily available substrate to more recalcitrant substrates in "Flood" or "Tide" due to rather fast changes of abiotic conditions such as salinity and moisture. Together with the nearly doubled amount prokaryotic biomass in "Low" (Table 2.1), this explains why "Low" has higher PE regarding longer time periods than "Pio" for the case of "Ebb"-treatments, since with a larger prokaryotic biomass the chance of cometabolic effects that lead to positive PE is greater (Cheng \& Coleman, 1990; Fontaine et al., 2003). These findings contradict our fourth hypothesis and 
might be explained as follows: A larger pool of inactive prokaryotes has higher priming potential due to metabolic activation by "trigger"-substrates like glucose than a soil with less prokaryotic biomass (Nobili et al., 2001). In this case, "triggering" means that the prokaryotic metabolic activity is highly stimulated by even slight increased concentrations of low molecular weight organic substances (LMWOS) in the environment (Mason-Jones \& Kuzyakov, 2017).

The higher prokaryotic biomass in "Low" might be due to closer proximity to the sea of "Pio" in the natural salt marsh ecosystem: Higher salt stress is negatively correlated to prokaryotic biomass (Ragab, 1993). In terms of PE, a higher content of C and N in soils promotes higher PE than under limited conditions (Hart et al., 1986; Kuzyakov et al., 2000). This can explain the greater PE response in "Low" compared to "Pio" under more favourable conditions as met in "Ebb" and "Tide". Moreover, due to rarer inundation in "Low", more recalcitrant $\mathrm{C}$ is accumulated in this salt marsh zone compared to "Pio", which gets flushed with easily available substrates by tidal inundation two times a day. This leads to the conclusion that in "Low" the addition of an easily available substrate has a higher "PE-activation-potential" than in "Pio" (Hamer \& Marschner, 2005). The absence of clear PE under "Flood" is because under anaerobic conditions decomposition of $\mathrm{OM}$ depends on its recalcitrance due to limitations of anaerobic bacteria to hydrolyse complex molecules (Canfield, 1994). Hence, easily degradable substances are equally fast decomposable under oxic or anoxic conditions but old substrate is not (Kristensen, 1995). There are similar trends in the overall $\mathrm{CO}_{2}$-efflux originated from glucose decomposition in all in all tidal treatments. However, the absence of PE may be explained there by the lacking capacity of anaerobic prokaryotes to decompose high molecular SOM before and after addition of glucose. Similar results support this finding with very limited evidence of priming under water flooded conditions (Kristensen \& Holmer, 2001).

\section{Bacterial and archaeal community structures}

As hypothesised, the flooding frequency had an influence on the long term prokaryotic community structure. As shown in other studies, prokaryotic communities exposed to varying water levels underlie strong physico-chemical effects (Bossio \& Scow, 1995; Weise et al., 2016) and need to be adapted to hypo- 
osmotic stress conditions (McKew et al., 2011). Changes in community composition were stronger for the "Ebb" treatment than for the water influenced treatments "Flood" and "Tide" (Figure 2.6 \& 2.7). This might be caused by lower C binding capacity of dried soil resulting in increasing $\mathrm{CO}_{2}$-efflux and correspondingly shifts in prokaryotic community composition, which in turn stimulate $\mathrm{C}$ turnover and fluxes in ecosystems (Fierer \& Schimel, 2002; Rezaie-Boroon et al., 2013; Schimel et al., 2007). As an example, archaeal community composition in all water level treatments was clearly dominated by Marine Group I Thaumarchaeaota except of "Low-Ebb". Although little is known about metabolic capabilities of archaea (Seyler et al., 2014), methanogenic Euryarchaeaota (Browne et al., 2017) and presumably autotrophic $\mathrm{CO}_{2}$ fixating Crenarchaeota (Hügler et al., 2003) instead of the ammonia oxidizing Marine Group I of the Thaumarchaeaota (Castelle et al., 2015; Yilmaz et al., 2016) were found in "Low-Ebb". In comparison to water level treatment, the soil origin (sampling location) played only a minor role based on the lower coefficient of determination. Nevertheless, these treatments together explain more than one third of data variance prokaryotic community structure.

Our analyses revealed that the prokaryotic community composition of the different sampling locations as well as the treatment-association of taxa altered under the water level treatments. This indicates changes in the functional profiles and temporal niche adaptation which can be observed for instance also after algal blooms (Teeling et al., 2012). "Pio" samples are characterised by prokaryotic clades with known marine representatives (Alain et al., 2002; DeLong, 1992; Guibert et al., 2016; Mußmann et al., 2017; Orsi et al., 2016; Ravot et al., 1999; Spring et al., 2015), some of which are unknown from other habitats, such as Haloferula and Roseibacter of the Verrucomicrobiales (Yoon et al., 2008a, b) and Haliea of the Cellvibrionales (Spring et al., 2015). Also, obligate anaerobes such as Caminicella, Fusibacter, Desulfobulbus, Desulfotignum and methanogenic Archaea are more abundant in the "Pio" samples compared to "Low" (Alain et al., 2002; DeLong, 1992; Kuever, 2014; Ravot et al., 1999). This can be explained by the frequent flooding events in "Pio", which 1) keep oxic, salinity and moisture conditions relatively close to marine sediments and 2) inoculate the location with marine prokaryotes. In contrast, the Planctomycetales and Rhodospirillales with relatively high abundance in the "Low" 
sampling location soils are aerobes known from diverse habitats (Bengtsson \& Øvreås, 2010; Neef et al., 1998) indicating a shift towards habitat generalists. Differences in the quality of dissolved organic matter cause decreasing abundance of several order belonging to Plantomycetales such as Blastospirellula, Planctomyces, Pir4 lineage and Rhodopirellula in treated "Low" soils compared to the natural "Low" soil (Tadonléké, 2007). Planctomyces use extracellular DNA from bacterial necromass very effectively for growth in soil (Morrissey et al., 2015). Thus, their high relative abundance in "Low" and their prominent indicator species status for "Ebb" and "Tide" might indicate niche adaptation with accelerated biomass turnover with decreasing seawater influence.

In conclusion, we show that the phenomenon of the PE is not restricted to terrestrial habitats, where most of present studies were carried out, but is also apparent in coastal ecosystems being highly influenced by tidal inundation. In salt marsh systems, inundation is a "master-parameter" in influencing of carbon sequestration and mineralisation. Moreover, flooding frequency shapes the local prokaryotic community by separation into specialists and generalists. Studies investigating the PE phenomenon especially in coastal ecosystems should consider prokaryotic communities and various forms of carbon ranging from easily available to recalcitrant and their temporal dynamics.

\section{Acknowledgements}

The authors are grateful to the administrations of the Lower Saxony and SchleswigHolstein Wadden Sea National Parks for allowance to sample in the field. Special thanks to Michaela Dippold and Yang Liu for technical and laboratory and Bernd Wemheuer for statistical support. 


\section{References}

Alain, K., Pignet, P., Zbinden, M., Quillevere, M., Duchiron, F., Donval, J.-P., Lesongeur, F., Raguenes, G., Crassous, P., Querellou, J. \& Cambon-Bonavita, M.-A. (2002). Caminicella sporogenes gen. nov., sp. nov., a novel thermophilic spore-forming bacterium isolated from an East-Pacific Rise hydrothermal vent. International Journal of Systematic and Evolutionary Microbiology, 52, 1621-1628.

Bartlett, K. B., \& Harriss, R. C. (1993). Review and assessment of methane emissions from wetlands. Chemosphere, 26, 261-320.

Bengtsson, M. M., \& Øvreås, L. (2010). Planctomycetes dominate biofilms on surfaces of the kelp Laminaria hyperborea. BMC Microbiology, 10, 261.

Bianchi, T. S. (2011). The role of terrestrially derived organic carbon in the coastal ocean: A changing paradigm and the priming effect. PNAS, 108(49), 1947319481.

Bossio, D. A., \& Scow, K. M. (1995). Impact of carbon and flooding on the metabolic diversity of microbial communities in soils. Applied and Environmental Microbiology, 61, 4043-4050.

Browne, P., Tamaki, H., Kyrpides, N., Woyke, T., Goodwin, L., Imachi, H., Bräuer, S., Yavitt, J. B., Liu, W.-T., Zinder, S., \& Cadillo-Quiroz, H. (2017). Genomic composition and dynamics among Methanomicrobiales predict adaptation to contrasting environments. The ISME Journal, 11, 87-99.

Camacho, C., Coulouris, G., Avagyan, V., Ma, N., Papadopoulos, J., Bealer, K., \& Madden, T. L. (2009). BLAST+: architecture and applications. BMC Bioinformatics, 10, 421.

Cannavo, P., \& Michel, J. C. (2013). Peat particle size effects on spatial root distribution, and changes on hydraulic and aeration properties. Scientia Horticulturae, 151, 11-21.

Canfield, D. E. (1994). Factors influencing organic carbon preservation in marine sediments. Chemical Geology, 114, 315-329.

Castelle, C. J., Wrighton, K. C., Thomas, B. C., Hug, L. A., Brown, C. T., Wilkins, M. J., Frischkorn, K. R., Tringe, S. G., Singh, A., Markillie, L. M., Taylor, R. C., Williams, K. H., \& Banfield, J. F. (2015). Genomic expansion of domain archaea highlights 
roles for organisms from new phyla in anaerobic carbon cycling. Current Biology, 25, 690-701.

Catalán, N., Kellerman, A. M., Peter, H., Carmona, F., \& Tranvik, L. J. (2015). Absence of a priming effect on dissolved organic carbon degradation in lake water: Absence of priming in lake water. Limnology and Oceanography, 60, 159-168.

Cheng, W., \& Coleman, D. C. (1990). Effect of living roots on soil organic matter decomposition. Soil Biology and Biochemistry, 22, 781-787.

Chmura, G. L., Anisfeld, S. C., Cahoon, D. R., \& Lynch, J. C. (2003). Global carbon sequestration in tidal, saline wetland soils. Global Biogeochemical Cycles, 17(4), 1111.

Craft, C. (2007). Freshwater input structures soil properties, vertical accretion, and nutrient accumulation of Georgia and U.S. tidal marshes. Limnology and Oceanography, 52, 1220-1230.

Craft, C., Clough, J., Ehman, J., Joye, S., Park, R., Pennings, S., Guo, H., \& Machmuller, M. (2009). Forecasting the effects of accelerated sea-level rise on tidal marsh ecosystem services. Frontiers in Ecology and the Environment, 7(2), 73-78.

Datta, R., Vranová, V., Pavelka, M., Rejšek, K., \& Formánek, P. (2014). Effect of soil sieving on respiration induced by low-molecular-weight substrates. International Agrophysics 28(1), 119-124.

Davidson, E. A., \& Janssens, I. A. (2006). Temperature sensitivity of soil carbon decomposition and feedbacks to climate change. Nature, 440, 165-173.

DeLong, E. F. (1992). Archaea in coastal marine environments. PNAS, 89, 5685-5689.

Doody, J. P. (2007). Saltmarsh conservation, management and restoration (Vol. 12). Springer Science \& Business Media.

Edgar, R. C. (2013). UPARSE: highly accurate OTU sequences from microbial amplicon reads. Nature Methods, 996-998.

Edgar, R. C., Haas, B. J., Clemente, J. C., Quince, C., \& Knight, R. (2011). UCHIME improves sensitivity and speed of chimera detection. Bioinformatics, 27, 21942200.

Fierer, N., \& Schimel, J. P. (2002). Effects of drying-rewetting frequency on soil carbon and nitrogen transformations. Soil Biology and Biochemistry, 34, 777-787. 
Fontaine, S., Mariotti, A., \& Abbadie, L. (2003). The priming effect of organic matter: a question of microbial competition? Soil Biology and Biochemistry, 35, 837-843.

Freeman, C., Ostle, N., \& Kang, H. (2001). An enzymic "latch" on a global carbon store. Nature, 409(6817), 149.

Froelich, P. N., Klinkhammer, G. P., Bender, M. L., Luedtke, N. A., Heath, G. R., Cullen, D., Dauphin, P., Hammond, D., Hartman, B., \& Maynard, V. (1979). Early oxidation of organic matter in pelagic sediments of the eastern equatorial Atlantic: suboxic diagenesis. Geochimica et Cosmochimica Acta, 43, 1075-1090.

Gifford, S. M., Sharma, S., Booth, M., \& Moran, M. A. (2013). Expression patterns reveal niche diversification in a marine microbial assemblage. The ISME Journal, 7, 281-298.

Guenet, B., Danger, M., Abbadie, L., \& Lacroix, G. (2010). Priming effect: bridging the gap between terrestrial and aquatic ecology. Ecology, 91, 2850-2861.

Guibert, L. M., Loviso, C. L., \& Borglin, S. (2016). Diverse bacterial groups contribute to the alkane degradation potential of chronically polluted subantarctic coastal sediments. Microbology Ecology, 71, 100-112.

Hamer, U., \& Marschner, B. (2005). Priming effects in different soil types induced by fructose, alanine, oxalic acid and catechol additions. Soil Biology and Biochemistry, 37, 445-454.

Hart, P. B. S., Rayner, J. H., \& Jenkinson, D. S. (1986). Influence of pool substitution on the interpretation of fertilizer experiments with 15N. European Journal of Soil Science, 37, 389-403.

Hemminga, M. A., \& Buth, G. J. C. (1991). Decomposition in salt marsh ecosystems of the S.W. Netherlands: the effects of biotic and abiotic factors. Vegetatio, 92, 7383.

Hügler, M., Huber, H., Stetter, K. O., \& Fuchs, G. (2003). Autotrophic $\mathrm{CO}_{2}$ fixation pathways in archaea (Crenarchaeota). Archives Microbiology, 179(3), 160-173.

Jobbágy, E. G., \& Jackson, R. B. (2001). The distribution of soil nutrients with depth: global patterns and the imprint of plants. Biogeochemistry, 53(1), 51-77.

Karius, V., \& Machunze, C. (2011). Dynamische Küsten: Grundlagen, Zusammenhänge und Auswirkungen im Spiegel angewandter Küstenforschung. Coastline Reports, 17, 5-18. 
Kirwan, M. L., \& Megonigal, J. P. (2013). Tidal wetland stability in the face of human impacts and sea-level rise. Nature, 504, 53-60.

Kirwan, M. L., Langley, J. A., Guntenspergen, G. R., \& Megonigal, J. P. (2013). The impact of sea-level rise on organic matter decay rates in Chesapeake Bay brackish tidal marshes. Biogeosciences, 10, 1869-1876.

Koretsky, C. M., Van Cappellen, P., DiChristina, T. J., Kostka, J. E., Lowe, K. L., Moore, C. M., Roychoudhury, A. N., \& Viollier, E. (2005). Salt marsh pore water geochemistry does not correlate with microbial community structure. Estuarine, Coastal and Shelf Science, 62, 233-251.

Kristensen, E., \& Holmer, M. (2001). Decomposition of plant materials in marine sediment exposed to different electron acceptors $\left(\mathrm{O}_{2}, \mathrm{NO}^{3-}\right.$, and $\left.\mathrm{SO}_{4}{ }^{2-}\right)$, with emphasis on substrate origin, degradation kinetics, and the role of bioturbation. Geochimica et Cosmochimica Acta, 65, 419-433.

Kristensen, T. S. (1995). The demand-control-support model: Methodological challenges for future research. Stress \& Health, 11(1), 17-26.

Kuever, J. (2014). The Family Desulfobulbaceae. The Prokaryotes. Berlin, Heidelberg: Springer, 75-86.

Kuzyakov, Y., \& Bol, R. (2006). Sources and mechanisms of priming effect induced in two grassland soils amended with slurry and sugar. Soil Biology and Biochemistry, 38, 747-758.

Kuzyakov, Y., Friedel, J. K., \& Stahr, K. (2000). Review of mechanisms and quantification of priming effects. Soil Biology and Biochemistry, 32(11-12), 1485-1498.

Kuzyakov, Y., \& Siniakina, S. V. A (2001). Novel method for separating root-derived organic compounds from root respiration in non-sterilized soils. Journal of Plant Nutrition and Soil Science, 164(5), 511-517.

Langley, J. A., McKee, K. L., Cahoon, D. R., Cherry, J. A., \& Megonigal, J. P. (2009). Elevated $\mathrm{CO}_{2}$ stimulates marsh elevation gain, counterbalancing sea-level rise. PNAS, 106, 6182-6186.

Mason-Jones, K., \& Kuzyakov, Y. (2017). "Non-metabolizable" glucose analogue shines new light on priming mechanisms: Triggering of microbial metabolism. Soil Biology and Biochemistry, 107, 68-76. 
McKew, B. A., Taylor, J. D., McGenity, T. J., \& Underwood, G. J. (2011). Resistance and resilience of benthic biofilm communities from a temperate saltmarsh to desiccation and rewetting. The ISME Journal, 5, 30-41.

Mendelssohn, I. A., Sorrell, B. K., Brix, H., Schierup, H.-H., Lorenzen, B., \& Maltby, E. (1999). Controls on soil cellulose decomposition along a salinity gradient in a Phragmites australis wetland in Denmark. Aquatic Botany, 64, 381-398.

Miller, W. D., Neubauer, S., \& Anderson, I. (2001). Effects of sea level induced disturbances on high salt marsh metabolism. Estuaries, 357-367.

Morrissey, E. M., McHugh, T. A., Preteska, L., Hayer, M., Dijkstra, P., Hungate, B. A., \& Schwartz, E. (2015). Dynamics of extracellular DNA decomposition and bacterial community composition in soil. Soil Biology and Biochemistry, 86, 4249.

Mueller, P., Jensen, K., \& Megonigal, P. (2016). Plants mediate soil organic matter decomposition in response to sea level rise. Global Change Biology, 22(1), 404414.

Mußmann, M., Pjevac, P., Krüger, K., \& Dyksma, S. (2017). Genomic repertoire of the Woeseiaceae/JTB255, cosmopolitan and abundant core members of microbial communities in marine sediments. The ISME Journal, 11(5), 1276-1281.

Neef, A., Amann, R., Schlesner, H., \& Schleifer, K.-H. (1998). Monitoring a widespread bacterial group: in situ detection of planctomycetes with 16S rRNA-targeted probes. Microbiology, 144, 3257-3266.

Nobili, M. D., Contin, M., Mondini, C., \& Brookes, P. C. (2001). Soil microbial biomass is triggered into activity by trace amounts of substrate. Soil Biology and Biochemistry, 33, 1163-1170.

Nuttle, W. (1988). The extent of lateral water movement in the sediments of a New England Salt Marsh. Water Resources Research, 24, 2077-2085.

Nyman, J. A., \& DeLaune, R. D. (1991). $\mathrm{CO}_{2}$ emission and soil Eh responses to different hydrological conditions in fresh, brackish, and saline marsh soils. Limnology and Oceanography, 36, 1406-1414.

Orsi, W., Smith, J. M., Liu, S., Liu, Z., Sakamoto, C. M., Wilken, S., Poirier, C., Richards, T. A., Keeling, P. J., Worden, A. Z., \& Santoro, A. E. (2016). Diverse, uncultivated 
bacteria and archaea underlying the cycling of dissolved protein in the ocean. The ISME Journal, 10, 2158-2173.

Peeters, J. C. H., \& Peperzak, L. (1990). Nutrient limitation in the North Sea: A bioassay approch. Netherlands Journal of Sea Research, 26(1), 61-73.

Ponnamperuma, F. N. (1972). The chemistry of submerged soils. Advances in Agronomy, 24, 29-96.

Quast, C., Pruesse, E., Yilmaz, P., Gerken, J., Schweer, T., Yarza, P., Peplies, J., \& Glöckner, F. O. (2012). The SILVA ribosomal RNA gene database project: improved data processing and web-based tools. Nucleic Acids Research, 41, D590-D596.

Ragab, M. (1993). Distribution pattern of soil microbial population in salt-affected soils. Towards the rational use of high salinity tolerant plants. Tasks for vegetation science. Dordrecht: Springer, 27, 467-472.

Ravot, G., Magot, M., Fardeau, M.-L., Patel, B. K. C., Thomas, P., Garcia, J.-L., \& Ollivier, B. (1999). Fusibacter paucivorans gen. nov., sp. nov., an anaerobic, thiosulfatereducing bacterium from an oil-producing well. International Journal of Systematic and Evolutionary Microbiology, 49, 1141-1147.

Reed, D. J. (1995). The response of coastal marshes to sea-level rise: Survival or submergence? Earth Surface Processes and Landforms, 20, 39-48.

Rezaie-Boroon, M. H., Diaz, S., Torres, V., Lazzaretto, T., \& Deheyn, D. D. (2013). Coupling between the changes in $\mathrm{CO}_{2}$ concentration and sediment biogeochemistry in the Salinas De San Pedro mudflat, California, USA. Journal of Environmental Protection, 4, 1173-1180.

Schimel, J., Balser, T. C., \& Wallenstein, M. (2007). Microbial stress-response physiology and its implications for ecosystem function. Ecology, 88, 13861394.

Seyler, L. M., McGuinness, L. M., \& Kerkhof, L. J. (2014). Crenarchaeal heterotrophy in salt marsh sediments. The ISME Journal, 8, 1534-1543.

Spring, S., Scheuner, C., Göker, M. \& Klenk, H.-P. (2015). A taxonomic framework for emerging groups of ecologically important marine gammaproteobacteria based on the reconstruction of evolutionary relationships using genome-scale data. Frontiers in Microbiology, 6, 281. 
Tadonléké, R. D. (2007). Strong coupling between natural Planctomycetes and changes in the quality of dissolved organic matter in freshwater samples: Planctomycetes and dissolved organic matter. FEMS Microbiology Ecology, 59, 543-555.

Teeling, H. M., Fuchs, B., Becher, D., Klockow, C., Gardebrecht, A., Bennke, C. M., Kassabgy, M., Huang, S., Mann, A. J., Waldmann, J., Weber, M., Klindworth, A., Otto, A., Lange, J., Bernhardt, J., Reinsch, C., Hecker, M., Peplies, J., Bockelmann, F. D., Callies, U., Gerdts, G., Wichels, A., Wiltshire, K. H., Glöckner, F. O., Schweder, T., \& Amann, R. (2012). Substrate-controlled succession of marine bacterioplankton populations induced by a phytoplankton bloom. Science, $336,608-611$.

Veen, J. A. V., \& Kuikman, P. J. (1990). Soil structural aspects of decomposition of organic matter by micro-organisms. Biogeochemistry, 11, 213-233.

Weise, L., Ulrich, A., Moreano, M., Gessler, A., Kayler, Z. E., Steger, S., Zeller, B., Kristin Rudolph, K., Knezevic-Jaric, J., \& Premke, K. (2016). Water level changes affect carbon turnover and microbial community composition in lake sediments. FEMS Microbiology Ecology, 92(5).

Wemheuer, B., Güllert, S., Billerbeck, S., Giebel, H.-A., Voget, S., Simon M., \& Daniel, R. (2014). Impact of a phytoplankton bloom on the diversity of the active bacterial community in the southern North Sea as revealed by metatranscriptomic approaches. FEMS Microbiology Ecology, 87, 378-389.

IUSS Working Group WRB (2014). World reference base for soil resources - A framework for international classification, correlation and communication. Rome, Food and Agriculture Organization of the United Nations

Yilmaz, P., Yarza, P., Rapp, J. Z., \& Glöckner, F. O. (2016). Expanding the world of marine bacterial and archaeal clades. Frontiers in Microbiology, 6, 1524.

Yoon, J., Matsuo, Y., Adachi, K., Nozawa, M., Matsuda, S., Kasai, H., \& Yokota, A. (2008a). Description of Persicirhabdus sediminis gen. nov., sp. nov., Roseibacillus ishigakijimensis gen. nov., sp. nov., Roseibacillus ponti sp. nov., Roseibacillus persicicus sp. nov., Luteolibacter pohnpeiensis gen. nov., sp. nov. and Luteolibacter algae sp. nov., six marine members of the phylum "Verrucomicrobia", and emended descriptions of the class Verrucomicrobiae, 
the order Verrucomicrobiales and the family Verrucomicrobiaceae. International Journal of Systematic and Evolutionary Microbiology, 58, 9981007.

Yoon, J., Matsuo, Y., Katsuta, A., Jang, J.-H., Matsuda, S., Adachi, K., Kasai, H., \& Yokota, A. (2008b). Haloferula rosea gen. nov., sp. nov., Haloferula harenae sp. nov., Haloferula phyci sp. nov., Haloferula helveola sp. nov. and Haloferula sargassicola sp. nov., five marine representatives of the family Verrucomicrobiaceae within the phylum "Verrucomicrobia." International Journal of Systematic and Evolutionary Microbiology, 58, 2491-2500. 
Chapter 2 


\section{Chapter 3}

\section{Diversity of decomposing flies and carcass decay in experimental salt marsh islands of the North Sea, Germany}

Hagen Andert ${ }^{1}$, Thomas Dinter ${ }^{1}$, Teja Tscharntke, Oliver Piskurek, Stefan Scheu, Yakov Kuzyakov, Christoph Scherber

${ }^{1}$ Equally contributing

In preparation to be submitted to Proceedings of the Royal Society $B$

Author contributions

HA and TD designed and conducted sampling in the field, analysed the data and drafted the manuscript; OP performed PCR; CS developed statistical models; TT, SS, YK participated in writing the manuscript 


\section{Abstract}

Understanding island colonisation by organisms and their contribution to ecosystem functioning is a major focus in ecology, but colonisation of standardised, experimental islands in the sea has rarely been investigated. Decomposition is a major ecosystem service linking at least two trophic levels. In this study, we performed an animal decomposition experiment using an experimental approach on the barrier island of Spiekeroog, Germany. 264 pieces of cow meat were spread over 12 experimental islands and six enclosed onshore plots established in late 2014 to observe animal decay in a real-time experiment. Within a two-week period, we investigated the influence of time and ecosystem disturbance on carcass biomass loss, while the habitat zonation (meaning the pioneer zone (Pio), lower salt marsh zone (Low) and upper salt marsh zone (Upp)) of the 18 plots did not contribute to the explanation. Animal extraction from the carrion and the soil beneath highlighted maggots as the taxon with highest abundances, with Scatophaga stercoraria $(\mathrm{n}=670)$, Hydrotaea dentipes $(\mathrm{n}=590)$ and Spelobia luteilabris $(\mathrm{n}=235)$ playing a major role. Maggot community composition changed between the marine dominated Pio up to the more terrestrial characterised Upp. In Pio, we recorded three maggot species, whereas in Upp, we found ten species. Interestingly, higher species richness of maggots was related to higher nutrient release, i.e. total content of carbon (C) and nitrogen $(\mathrm{N})$ in accordance with plant-extractable phosphorous ( $\mathrm{Pex}_{\mathrm{e}}$ ) during decomposition, resulting in a lower $\mathrm{C} / \mathrm{N}$-ratio in the soil beneath the carcass.

Keywords: Animal decomposition, BEFmate, Brachycera, carcass, flies, salt marshes, soil organic matter, TTIB 


\subsection{Introduction}

For centuries, islands were in the main focus of several ecological and evolutionary studies as they are area restricted, geographically isolated and less complex than larger mainland areas (Whittaker, 1998; Losos \& Ricklefs, 2009). For the last 50 years, beside species interaction networks and the assembly of island communities through different time scales, initialised by the fundamental monography of MacArthur and Wilson (1967), colonisation processes represented the main direction of island biogeography (Santos et al., 2016). Within the last years, research on ecosystem functioning has become more important, especially within the topics of parasite-host interactions and predation (Whittaker et al., 2014; Santos et al., 2016). As decomposition is one of the most important ecosystem functioning processes, its effect on biodiversity and community ecology has become one of ecology's major topics over the last years (Parmenter \& MacMahon, 2009; Barton et al., 2013). The decomposition of animal carcasses acts as a short-lived and infrequent resource pulse (Yang et al., 2008) with both short- and long-term effects on plant growth (Barton et al., 2013; Parmenter \& MacMahon, 2009). As a result, decomposing carcasses can function as localised islands of enhanced species pools and soil fertility, a "Cadaver Decomposition Island (CDI)" (Benninger, 2008), characterised by changes in the dominance structure of decomposers (Tabor et al., 2004). Microbial communities mineralise carcass tissue and transform complex organic compounds into readily plant-available nutrients (Parmenter \& MacMahon, 2009).

Previous attempts to model decomposition mainly stressed abiotic factors such as soil type, ambient temperature, humidity or elevation (Tabor et al., 2004) and focussed on terrestrial habitats. Until now, studies neglected carcass decomposition processes on islands, and even principal processes such as biomass loss, accessibility of plant related nutrients or changes in decomposer community composition have remained largely unexplored (but see Richards et al., 2015; Parmenter \& Macmahon, 2009). Studies in marine habitats show that there is a lack of insect scavengers, as insects are not permanent inhabitants of marine habitats. However, salinity and water saturation influence animal tissue decomposition massively (Anderson \& Bell, 2016; Richards et al., 2015). Previous studies have used existing gradients in salt marsh habitats; in this study, we employ a less common approach by establishing 
experimental salt marsh islands indirectly influencing tidal inundation frequencies mimicking disturbance intensities. In contrast to former studies, this allows us to isolate effects of particular explanatory variables on the decomposition process. We expose pieces of cow meat and study ecosystem processes on experimental Islands (EI) and salt marsh enclosed plots (SM) as controls in a salt marsh system. We examine the abundance and species richness of carcass decomposing flies and larvae as a function of abiotic factors (i.e. salinity, water saturation, soil texture, etc.). Furthermore, we study the short-term enrichment in total carbon (C), total nitrogen (N) and plant-available, extractable phosphorous $\left(\mathrm{P}_{\mathrm{ex}}\right)$ in the soil beneath the decaying substrate. We explicitly link decomposition to community attributes and our hypotheses are the following:

1) Animal decay proceeds slower in the marine-influenced pioneer zone (Pio) than in the transitional lower salt marsh zone (Low) or the terrestrial upper salt marsh zone (Upp) due to abiotic stress for decomposers.

2) Decomposing invertebrate communities differ between EI- and SM-plots with EI-communities being highly mobile.

3) Plant-available nutrients release is depending on the decomposition process and therefore on decomposing maggot species.

\subsection{Material and methods}

\section{Study site}

The experiment was conducted in the back-barrier region of Spiekeroog Island in the

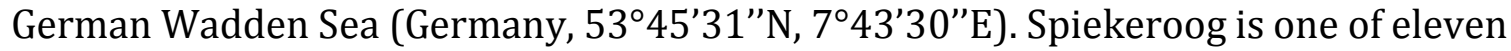
East Frisian barrier islands that have been formed during the Holocene mostly by sedimentation- and erosion processes that continue to shape the islands' morphology (Streif, 1990). Towards the Wadden Sea, the transition from a terrestrial to a marine environment results in the three main habitat zones: Pio, Low and Upp. Pio is characterised by daily inundation every six hours and has an elevation of approx. 0.5 to $0 \mathrm{~m}$ below mean high water tide. Dominant plant species are Spartina anglica, adapted to high salt concentrations. Low is an intermediate zone which is flooded only at spring tides. It is localised 0 to $+0.5 \mathrm{~m}$ above MHT and inhabits Puccinellia maritima and Aster tripolium as typical plant species. The most elevated zone (Upp) 
with $>0.5 \mathrm{~m}$ above MHT is flooded only during extreme spring tides and storm events. This zone is dominated by Elymus athericus. The soil of the sampling site is a salic fluvisol (WRB) which is characterised by loamy sand overlain by a $20-30 \mathrm{~cm}$ thick layer of clayey to sandy silt. Mean temperature for September 2015 was $14.44^{\circ} \mathrm{C}$ with negligible precipitation.

\section{Experimental design}

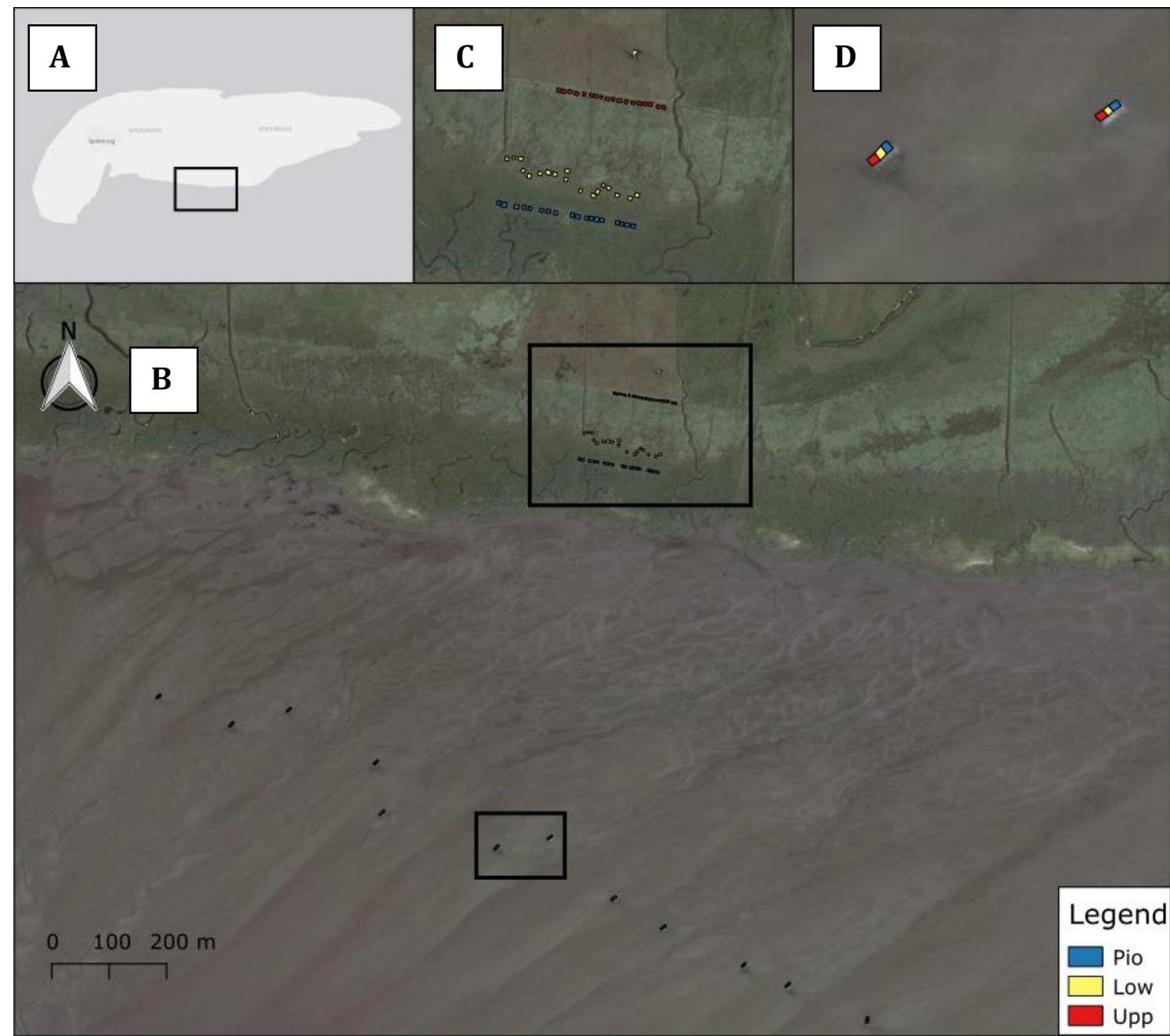

Figure 3.1 A Location and design of the experimental plots and the different habitat zonation. Location of the experiment at the south side of Spiekeroog island; B Experimental setup with a total of 12 experimental islands and salt marsh enclosed plots; C Salt marsh enclosed plots in the salt marsh system grouped according to Pio, Low and Upp; D Orientation of experimental islands in North-East direction

In autumn 2014, 12 EI were installed in the Wadden Sea, 500 m south of Spiekeroog together with 12 onshore control plots (SM) within each salt marsh zone (Figure 3.1). Elevation of EI and SM was adjusted to the naturally occurring salt marsh zones Pio, 
Low and Upp. Half of these EI and SM plots were modified by vegetation and topsoil removal followed by replacement with sand from the surrounding Wadden Sea tidal flat (non-planted). Considering the other half, the naturally occurring vegetation was substituted by Low-vegetation sods (planted). An overview about the procedure is given in Figure 3.2. Detailed information about the construction and experimental design of the experimental islands can be found in Balke et al. (2017). For this study, we used Pio-, Low- and Upp-elevations of $10 \mathrm{EI}$ and $10 \mathrm{SM}$ plots half were planted and half non-planted.

In September 2015, 264 pieces of phrenic cattle meat was cut to pieces of $3 \times 3 \mathrm{~cm}$ in size corresponding to $7.8 \mathrm{~g}$ dry weight. Substrate was wrapped in PVCcovered chicken wire (mesh size: $25 \mathrm{~mm}$ ), with drilled spines to prevent attacks by scavenging birds or mammals in the field. Three samples per plot were anchored using wooden sticks as a protection against tidal currents. To measure initial conditions, soil cores $(\oslash 5 \times 3 \mathrm{~cm})$ were sampled to determine the background soil arthropod fauna and the soil nutrient status. After timesteps of 3, 7 and 14 days, one of the three decaying meat pieces per plot was randomly sampled and stored in polyethylene-bags of $1 \mathrm{~L}$ at $4^{\circ} \mathrm{C}$ until further analysis. The same procedure was carried out for soil samples using a $\oslash 7 \times 5 \mathrm{~cm}$ corer. Soil samples were separated into two aliquots for arthropod extraction and soil nutrient analysis. Flies and other easily accessible arthropods were collected from each sample using spring steel forceps and stored in $70 \%$ ethanol. 


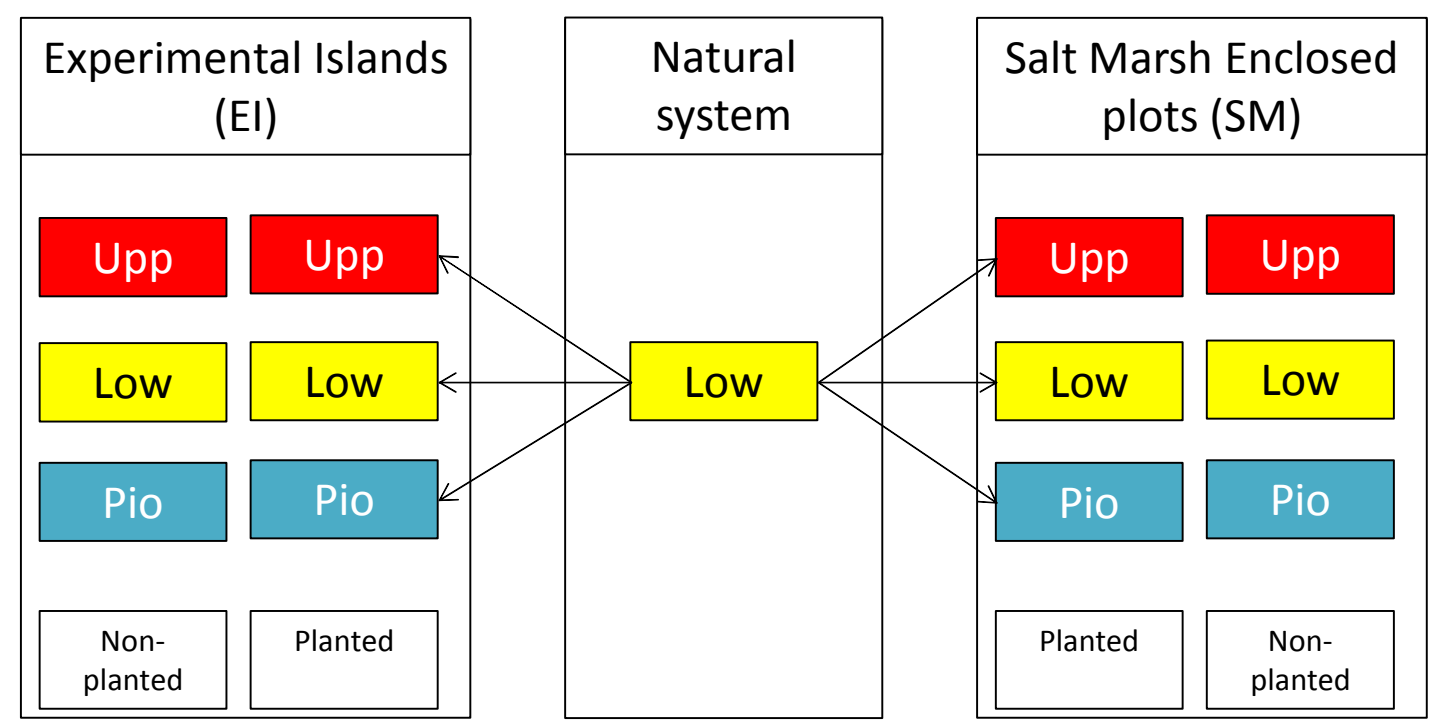

Figure 3.2 Experimental design of the sod transplantation after Balke et al. (2017). Lower salt marsh sods were taken from the natural system of Spiekeroog and then transplanted onto plots filled with Wadden Sea sand (EI and SM planted). Besides the planted plots, also non-planted plots were prepared, which were only filled with Wadden Sea sediment.

For the extraction of the remaining larvae and adults, the PE-bag was filled with water and shaken for 20 seconds. The supernatant was filtered through a strainer $(1 \mathrm{~mm}$ mesh size), washed again and filled into Falcon ${ }^{\circledR}$ tubes (50 mL, Sarstedt, Inc.) with 70\% ethanol. Remaining pieces of meat were dried in an oven (Memmert GmbH, Germany) for four days at $65^{\circ} \mathrm{C}$ and maximal aeration and weighed (Sartorius AG, Germany).

Soil arthropods were extracted by using a Kempson extractor (Kempson et al., 1963) following a commonly used protocol (S1) for 8 days. Arthropods were extracted into ethylene glycol and directly transferred into 70\% EtOH after washing. Arthropod families were identified under a stereomicroscope (Leica) using taxonomic literature (Dunger \& Fiedler, 1999; Bährmann, 2008). Adult flies were identified up to family level (Oosterbroek \& Hurkmans, 2006). Fly larvae were identified using taxonomic keys (Szpila, 2009); identification was additionally verified using a barcoding approach. To identify decomposition-related maggot species, we used amplified 730bp sequences from the C01 region (Table 3.1) for a modified PCR protocol. Further information on barcoding and the sequencing protocol are given in S2. 
Chapter 3

Table 3.1 COI primer sequences used for barcoding the maggot species.

\begin{tabular}{ll}
\hline Primer & Primer sequence $\left(\mathbf{5}^{\mathbf{c}}-\mathbf{>} \mathbf{3}^{\mathbf{}} \mathbf{)}\right.$ \\
\hline ForEnt COI up & TTTCTACTAATCATAAAGATATTGGWACT \\
ForEnt COI low & AATCCAGGTAAAATTAAAATATATACTTC \\
Insect 18S for & GAAGGCGATCAGATACCGCCCTAGTTCTA \\
Insect 18S rev & GTAGCGCGCGTGCRGCCCA \\
\hline
\end{tabular}

For $\mathrm{C}$ and $\mathrm{N}$ analysis, air-dried soil samples were sieved to $2 \mathrm{~mm}$. One aliquot was pulverised in a ball-mill (Retsch $\mathrm{GmbH}$, Haan, Germany) at $200 \mathrm{rpm}$ for 5 minutes. $\mathrm{C}$ and $\mathrm{N}$ were determined photometrically in a combustion furnace (vario EL III; elementar, Hanau, Germany). Another aliquot was used to measure Pex (Schüller, 1969; Blume et al., 2011): 2 g of soil were diluted in $40 \mathrm{~mL}$ of Calcium-Acetat-Lactate (CAL)-solution and shaken for 90 min in polyethylen-bottles. After filtration, liquid samples were amended with an antimony-molybdate-complex and measured photometrically at $820 \mathrm{~nm}$ wavelength using a microplate reader (Infinite ${ }^{\circ} 200$ Pro, Tecan Switzerland).

\section{Statistical Analyses}

Data was analysed using R 3.3.2. (R Development Core Team 2016) using the packages 'effects' for model display, 'fitdistrplus' to fit parametric distributions, 'Ime4' to fit linear mixed-effect models, 'MASS' for ANOVA, 'MuMIn' for model selection via AICc, 'splines' to provide our models with B-splines, 'survey' for generating summary statistics and 'vegan' to calculate alpha-diversity, species richness and perform PerMANOVA analysis. Species richness of eleven decomposition-related maggot species were calculated via the package 'vegan'. In this study, maggot abundance data and species richness served as biotic variables using glmmPQL models from the 'MASS'-package due to their negative binomial error distribution (see R-code, Appendix A1). Additionally, we checked for homogenously distributed random effects. Overall, time had no effect on biotic variables. To exclude time as variable, we aggregated abundance of different maggot taxa with plot, zone and planted/non-planted treatment. To measure animal tissue decay, we assumed a nonlinear decay model after Olson (1963; see equation 3.1). 


$$
\frac{x}{x_{0}}=e^{(-k * t)}
$$

We achieved a linear relationship by taking logs on both sites and then analysed data in a mixed-effects model as follows (see equation 3.2):

$$
\log \left(\frac{x_{t}}{x_{0}}\right)=\log \left(x_{t}\right)-\log \left(x_{0}\right)=-k * t
$$

Based on the formula by Olsen (1963), we calculated a coefficient of decay $(k)$ for each data point after the initial measurement $\left(t_{0}\right)$. Mixed-effects models contained plot (i.e. site) with two levels and zone with three levels nested within plot as random effect. Predicted values were back-transformed by taking antilogs. We checked for effects of time, Shannon diversity of arthropods, species richness and total abundance of these animals both above- and below-ground on decomposition. To investigate the relationship of species occurrence probability in different plots and zones, we used Poisson-distributed manyglm and multinomial log-linear models to predict occurrence probability.

Finally, we applied further mixed effect models to assess the relationship between maggot-related variables (maggot abundance, species richness and abundance of the three most abundant species Hydrotaea dentipes, Scatophaga stercoraria and Spelobia luteilabris) and the change of C to N (C/N) during decomposition. These models contained plot identity (EI and SM), habitat zone (Pio, Low and Upp) and above- or below-ground location as random effects. Model fit was assessed using Akaike's information criterion, corrected for small sample sizes (AICc). Threshold for best fitted models was when $\triangle$ AICc $<2$ (Burnham \& Anderson, 2002). 


\subsection{Results}

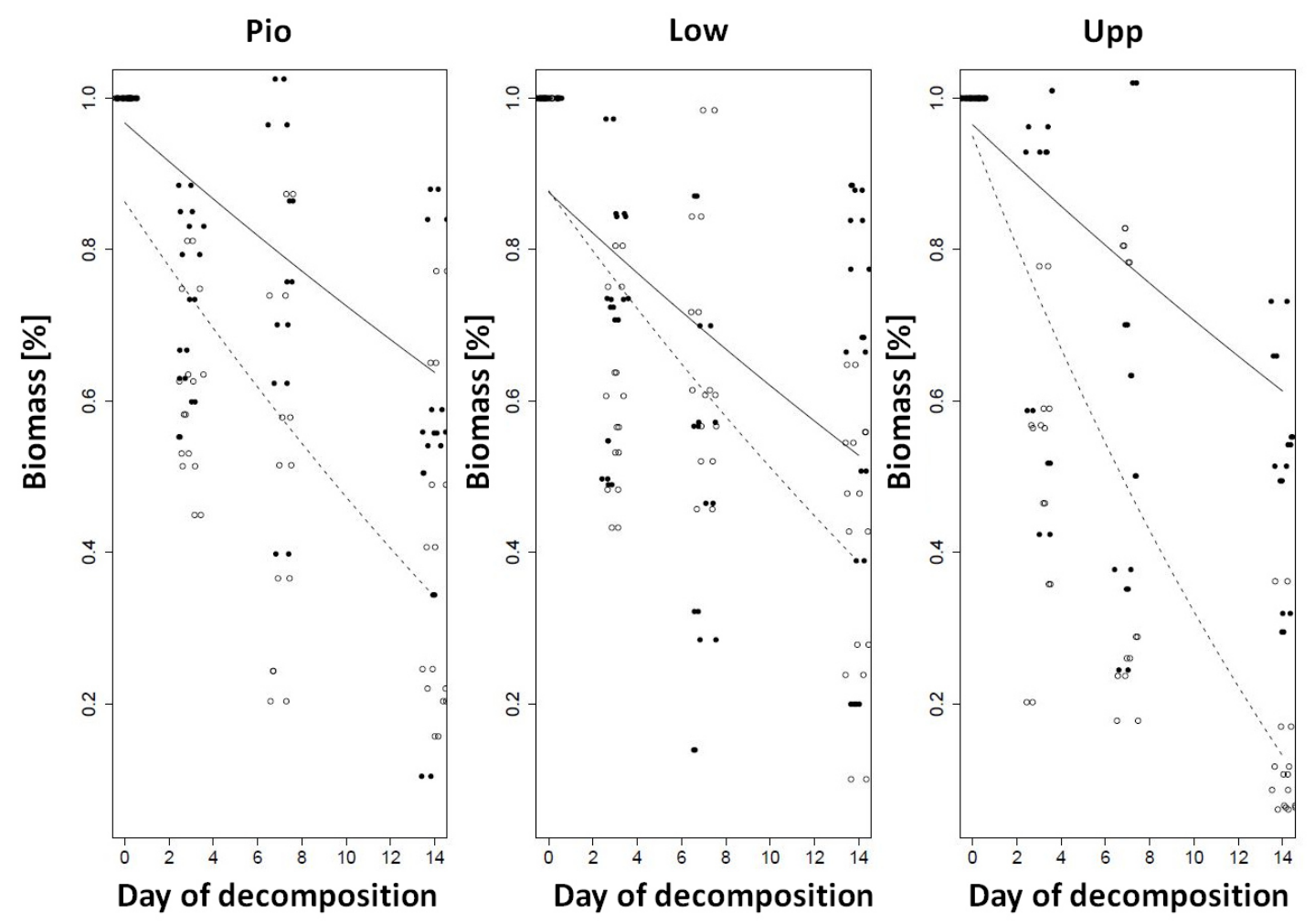

Figure 3.3 Biomass loss during decay over 14 days of decomposition. Our model prediction displays the amount of remaining biomass after ongoing decomposition time. Biomass loss could be observed in all plots. Between experimental treatments ( $\mathrm{EI}=$ solid, $\mathrm{SM}=$ dashed) significant differences could be found via or lme. In EI, no difference between zones could be recognised, but in SM, a significant difference could be calculated.

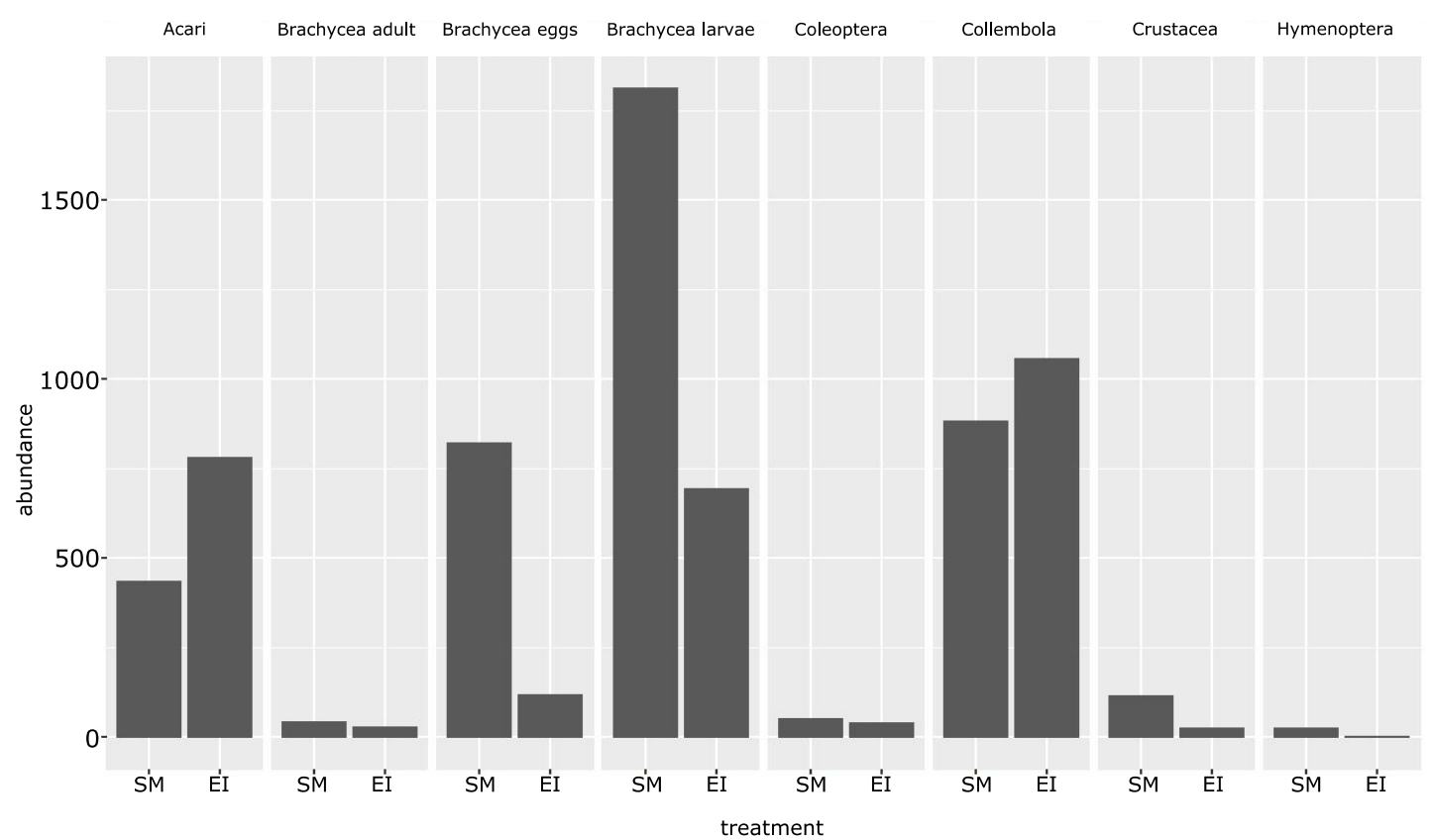

Figure 3.4 Abundance of the taxa found the most above and below our experimental setup. In our experimental setting, eight taxa occurred the most (in the order of highest abundance): Brachycera larvae (maggots), Collembola, Acari, Brachycera eggs (unhatched, fresh), Crustacea, Coleoptera, adult Brachycera and Hymenoptera. Brachycera larvae were verified the most, $n=3301$ ). In summary, carcasses of SM plots contained three times more individuals than of EI plots. 
The best fit linear mixed-effects model showed a highly significant positive influence of increasing time of decomposition ( $n u m D F=1, \operatorname{denDF}=372, F=233.1504, \mathrm{p}<0.001$ ) and plot identity (numDF=1, denDF=16, $\mathrm{F}=13.3183, \mathrm{p}<0.005$ ) on carcass biomass loss. There were characteristic differences in the predicted decomposition curve: For all three zones, the biomass loss was not significantly different (numDF=2, denDF=32, $F=0.89, p=0.4206)$. In SM plots, decomposition differed between zones: There was a clear correlation between plot distance from the marine habitat and the rate of weight-loss. After 14 days, approx. 40\% of carcass tissue remained in Pio and Low, whereas less than $10 \%$ of original carcass weight remained in a more terrestrial surrounding (see Figure 3.3 and S3.3).

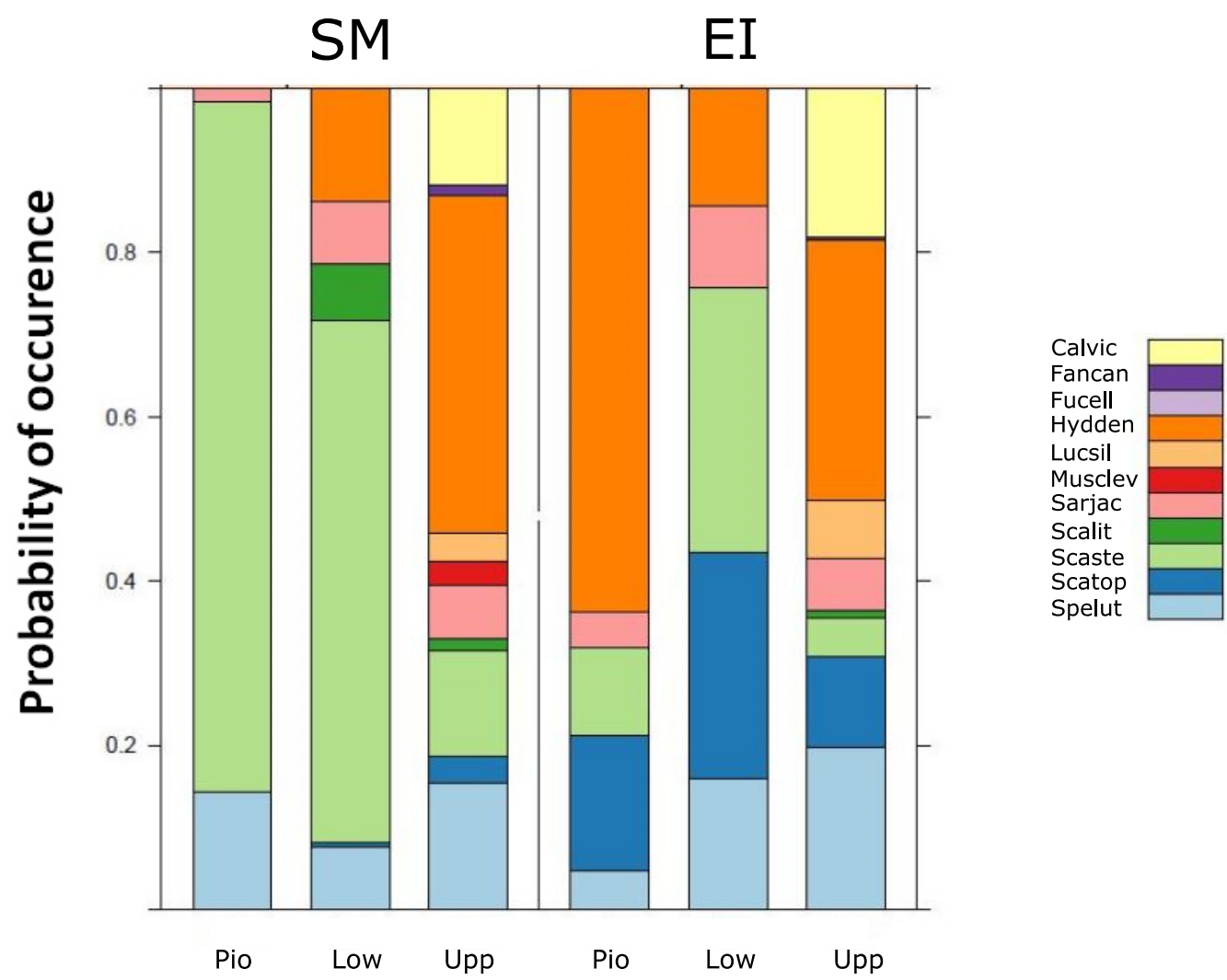

Figure 3.5 Standardised proportion of species occurrence of 11 most abundant decomposition related maggot species on all experimental plots. A significant difference between marine influenced pioneer zone communities and terrestrial associated maggot communities could be observed (manyglm, Deviance=1809.1, p=0.001), as well as an effect between plot types (Deviance=1059.5, $\mathrm{p}=0.001$ ). Calvic $=$ Calliphora vicina, Fancan=Fannia caniculairs, Fucell $=$ Fucellia tergina, Hydden $=$ Hydrotaea dentipes, Lucsil= Lucilia silvarum, Musclev= Muscina levida, Sarjac= Sarcophaga jacobsoni, Scalit= Scatophaga litorea, $\mathrm{Scaste}=S$. stercoraria , Scatop $=$ Rhegmoclematini gen sp . and Spelut $=$ Spelobia luteilabris. A significant community shift could be observed in the three most abundant maggot species Scatophaga stercoraria, Hydrotaea dentipes and Spelobia luteilabris. In SM plots, probability of Scatophaga-occurrence decreases, where proportion of Hydrotaea and Spelobia increase. 
Within the 14 days of decomposition 9,969 specimens from 23 taxa were sampled. Eight main taxa (Figure 3.4) represented 69.5\% of all specimens, including 2,507 fly larvae, which represent about $25 \%$ of all individuals. Within the Diptera larva (Table 3.2), 11 species were decomposer species according to their larval development and adult ecology: Calliphora vicina, Fannia canicularis, Fucellia tergina, Hydrotaea dentipes, Lucilia silvarum, Muscina levida, Sarcophaga jacobsoni, Scatophaga litorea, Scatophaga stercoraria, Rhegmoclematini gen. sp. and Spelobia luteilabris. The most abundant species were Scatophaga stercoraria $(\mathrm{n}=670)$, Hydrotaea dentipes $(\mathrm{n}=590)$ and Spelobia luteilabris $(\mathrm{n}=235)$ (Figure 3.4 and 3.6).

Table 3.2 Abundance data of maggot species. 11 maggot species occurred to be the most abundant ones in the experiment. Scatophaga stercoraria $(n=670)$, Hydrotaea dentipes $(n=590)$ and Spelobia luteilabris $(n=235)$ display a higher abundance in SM compared to EI. Both S. stercoraria and $S$. luteilabris show higher numbers in non-planted SM plots compared to planted SM plots in contrast to H. dentipes, which was more abundant in planted SM plots. In EI plots, all three species occurred more in planted plots than in non-planted EI plots.

\begin{tabular}{|c|c|c|c|c|c|c|c|c|c|c|c|c|}
\hline \multirow[b]{3}{*}{ taxon } & \multicolumn{6}{|c|}{ SM } & \multicolumn{6}{|c|}{ EI } \\
\hline & \multicolumn{3}{|c|}{ non-planted } & \multicolumn{3}{|c|}{ planted } & \multicolumn{3}{|c|}{ non-planted } & \multicolumn{3}{|c|}{ planted } \\
\hline & Pio & Low & Upp & Pio & Low & $U p p$ & Pio & Low & Upp & Pio & Low & $U p p$ \\
\hline Calliphora vicina & 0 & 0 & 47 & 0 & 1 & 45 & 0 & 0 & 57 & 0 & 8 & 0 \\
\hline Fannia canicularis & 0 & 0 & 3 & 0 & 15 & 5 & 0 & 0 & 0 & 0 & 0 & 1 \\
\hline Fucellia tergina * & 0 & 0 & 0 & 0 & 0 & 0 & 0 & 0 & 5 & 0 & 0 & 0 \\
\hline Hydrotaea dentipes & 0 & 25 & 90 & 0 & 82 & 185 & 6 & 1 & 49 & 87 & 21 & 44 \\
\hline Lucilia silvarum & 0 & 0 & 15 & 0 & 2 & 12 & 4 & 0 & 19 & 0 & 32 & 3 \\
\hline Muscina levida & 1 & 5 & 11 & 0 & 0 & 8 & 0 & 0 & 0 & 0 & 0 & 0 \\
\hline Sarcophaga jacobsoni & 0 & 36 & 27 & 1 & 20 & 16 & 5 & 0 & 0 & 0 & 8 & 18 \\
\hline Scatophaga litorea & 0 & 2 & 7 & 0 & 187 & 3 & 4 & 0 & 0 & 0 & 0 & 3 \\
\hline Scatophaga stercoraria & 8 & 374 & 62 & 0 & 144 & 33 & 1 & 0 & 10 & 11 & 23 & 4 \\
\hline $\begin{array}{l}\text { Rhegmoclematini gen. sp. } \\
* *\end{array}$ & 0 & 2 & 21 & 0 & 1 & 1 & 3 & 0 & 0 & 13 & 39 & 32 \\
\hline Spelobia luteilabris & 3 & 22 & 73 & 0 & 32 & 29 & 1 & 7 & 2 & 3 & 8 & 54 \\
\hline
\end{tabular}



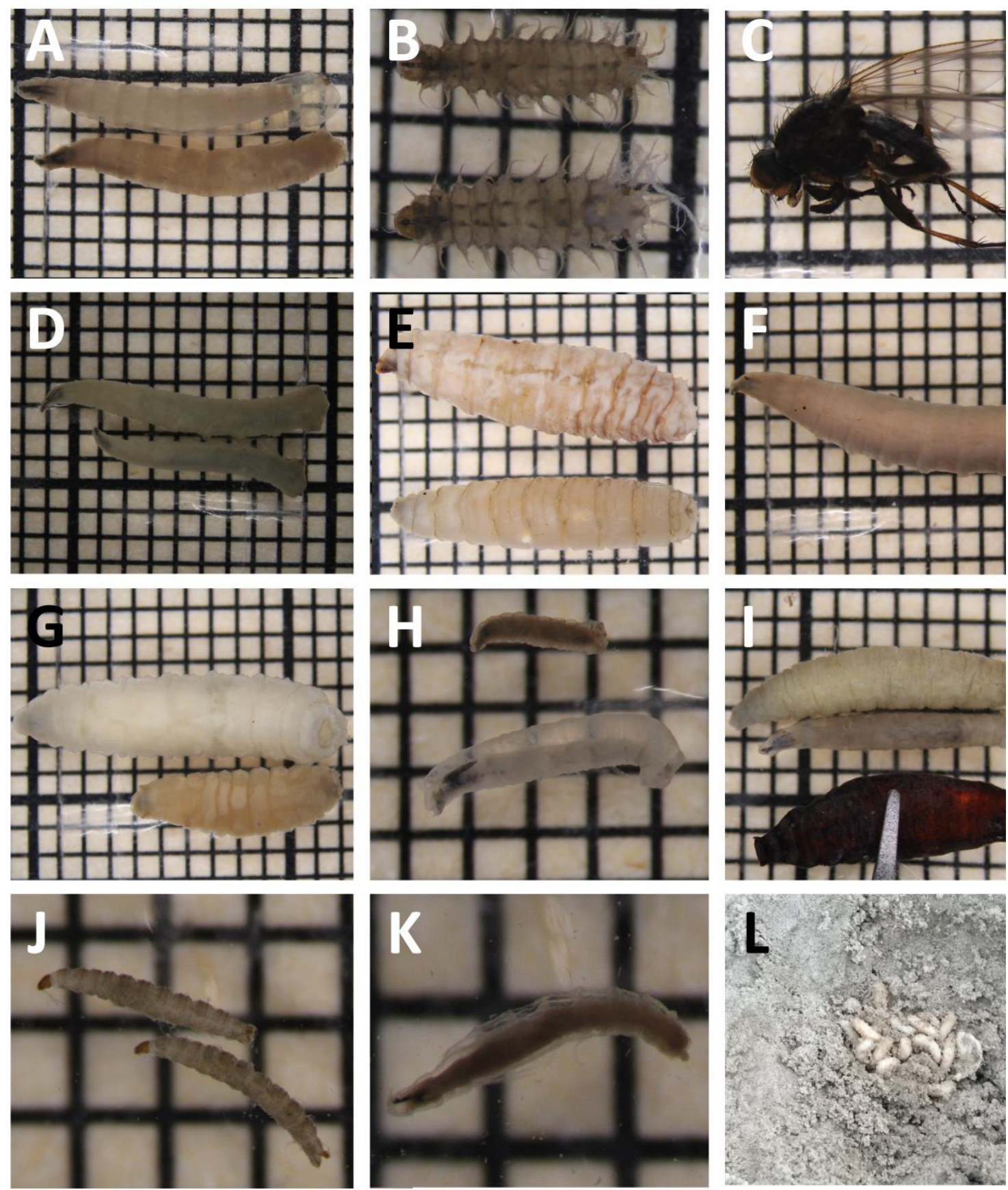

Figure 3.6 A Calliphora vicina, B Fannia canicularis, C Fucellia tergina (no maggot can be displayed here, shown adult is hatched from pupa), D Hydrotaea dentipes, E Lucilia silvarum, F Muscina levida, G Sarcophaga jacobsoni, H Scatophaga litorea, I Scatophaga stercoraria (larvae and pupa), J Rhegmoclematini gen. sp., K Spelobia luteilabris and $\mathbf{L}$ displays a maggot ball of a Calliphoridae species in Upp on a non-planted EI after 14 days of decomposition.

Our best fit manyglm model with Poisson error distribution showed that the probability of maggot species' occurrence mainly depends on the habitat zone where decomposition takes place (Res.Df=7, Df.diff=2, Deviance=1809.1, p=0.001). If 
divided into the plot types SM and EI, dominant species probability switches: While in SM the occurrence of Scatophaga stercoraria diminish from Pio to Upp (Figure 3.5), a probability decrease of about 71\%), the probability of Hydrotea dentipes occurrence strongly increases (approx. 41\%). In parallel, the amount of pioneer zone species increases from three to 10 species. On EI plots, Hydrotaea dentipes is the most probable species to find in the Pio (63.22\%). The occurrence probability of this species is decreasing towards terrestrial direction.

Similarly, when separated into planted and non-planted plots, the probability of Hydrotaea dentipes occurrence is increasing (about 30\%) in non-planted plots, where Scatophaga stercoraria is most abundant in lower salt marsh plots and slightly diminishing in upper salt marshes (decrease of about 61\%). In planted plots, Scatophaga stercoraria is most probable to find in Pio plots (probability of $88 \%$ ) and decreases in a terrestrial direction (-80\%), while the occurrence probability of Hydrotaea increases again (Figure 3.5, probability increase of 48\%). For Spelobia luteilabris, occurrence probability both increases over the salt marsh zonation for the EI (+15\%) and planted plots (+5\%). In SM plots, as well as in planted plots, the probability in Low is lowest compared to Pio or Upp. Other species are only slightly or insignificantly increasing if at all.

Our linear-mixed-effects (lme) model shows a distinct relationship between $\mathrm{C} / \mathrm{N}$-ratio and remaining biomass in all salt marsh zones (Figure 3.7A). With progressing decay, $\mathrm{C} / \mathrm{N}$-ratio also decreases in all plot types. However, the decline is different among boundary variables: The slope decreases from Pio to Upp on the SM with a change of two units in Pio (10 to 8) in comparison to one unit (10 to 9) in Upp. Regarding the EI, this trend is reversed with a steeper decline of remaining biomass in Upp compared to Low or Pio. Upp decreases by 3 units compared to Low and Pio with two units. Low is intermediate between these values. In Pio, soil C/N remains higher on EI than on SM at all decompositions stages, based on remaining tissue ( 9 in Pio compared to 8 in Upp).

In general, there are no clear differences in soil $\mathrm{C} / \mathrm{N}$ in our lme model considering salt marsh zones and presence (planted) or absence (non-planted) of vegetation (Figure 3.7B). In case of Pio and Low, both decomposition functions have very similar slopes and estimates. They start at values from 10 (100\% biomass remaining) to 8 (20\% biomass remaining). In Upp, the decline in $\mathrm{C} / \mathrm{N}$-ratio during 
decomposition is steeper, when plants were not present: The value ranges from 11 at the beginning of decomposition to 8,5 when the experiment was stopped in case of
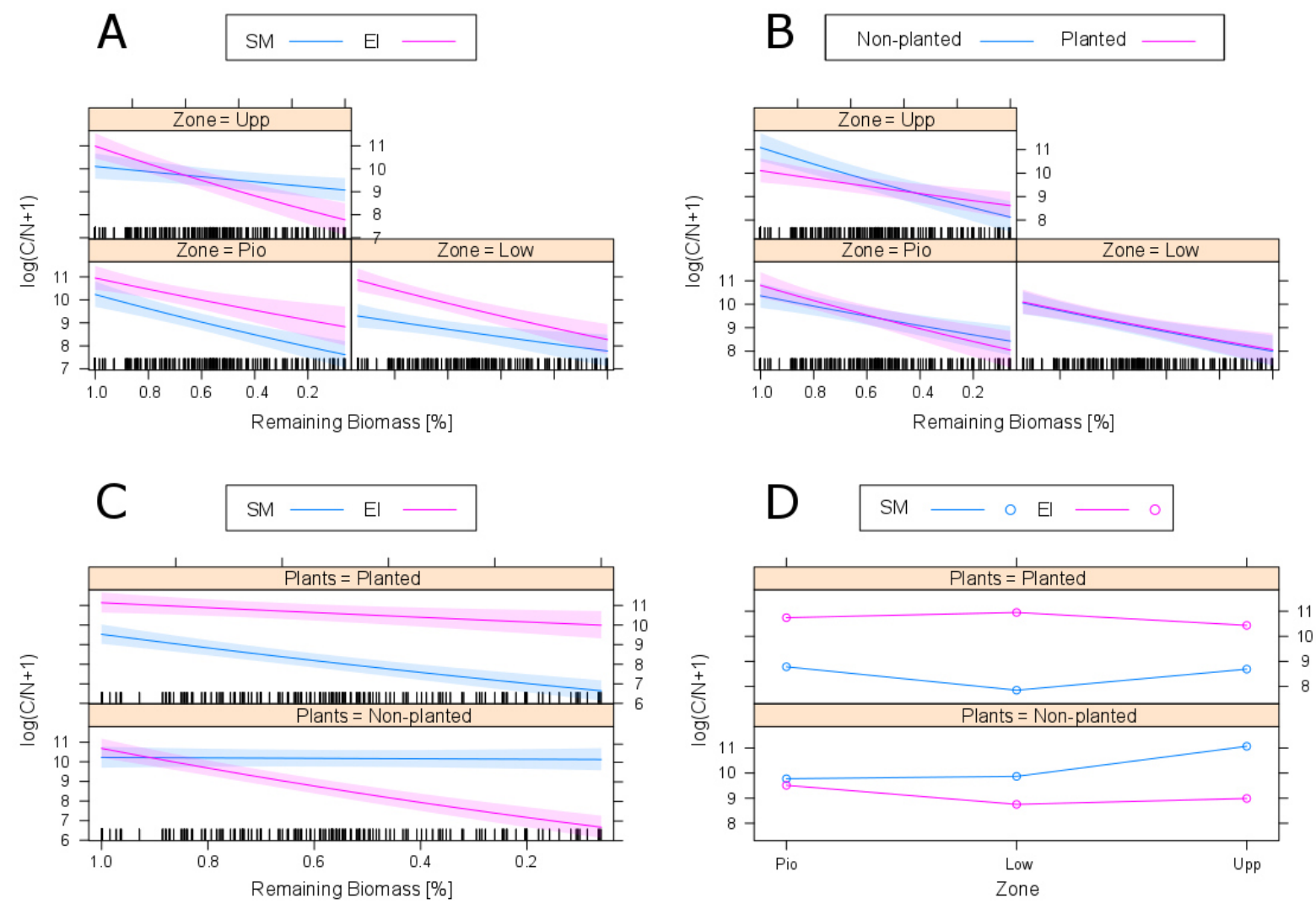

Figure 3.7 A Effect plots of log linear-mixed-effect models of C/N separated between plot-type, B presence or absence of plants, $\mathbf{C}$ with zones or $\mathbf{D}$ sampling timesteps as pooled parameters.

non-planted plots. With plants being present, the range is smaller with a lower starting point at 10 and a higher $\mathrm{C} / \mathrm{N}$-ratio at the end (9) compared to non-planted plots. In the model with salt marsh zones pooled, $\mathrm{C} / \mathrm{N}$-ratio drops with time of decay (Figure 3.7C). However, in non-planted SM is no significant trend visible and the C/Nratio is stable around values of 10 . On the opposite, we observe a steep decline on the EI: During the two weeks, the C/N-ratio drops by 4 units. When plants are present, the trends are reversed with a steeper decrease in C/N on SM than EI. In this case, the C/N-ratio drops only one unit (from 11 to 10 ) on EI and from 9,5 to 7 in SM.

Considering the data points over the whole time of decomposition the predicting models show that background soil C/N-ratio is higher on EI than on SM when there are plants present (Figure 3.7D). On EI, the C/N-ratio is approx. 2 units higher (11 vs. 9). This difference is constant over all three salt marsh zones with a slightly greater difference in Low. When no plants are present and pure sand remains 

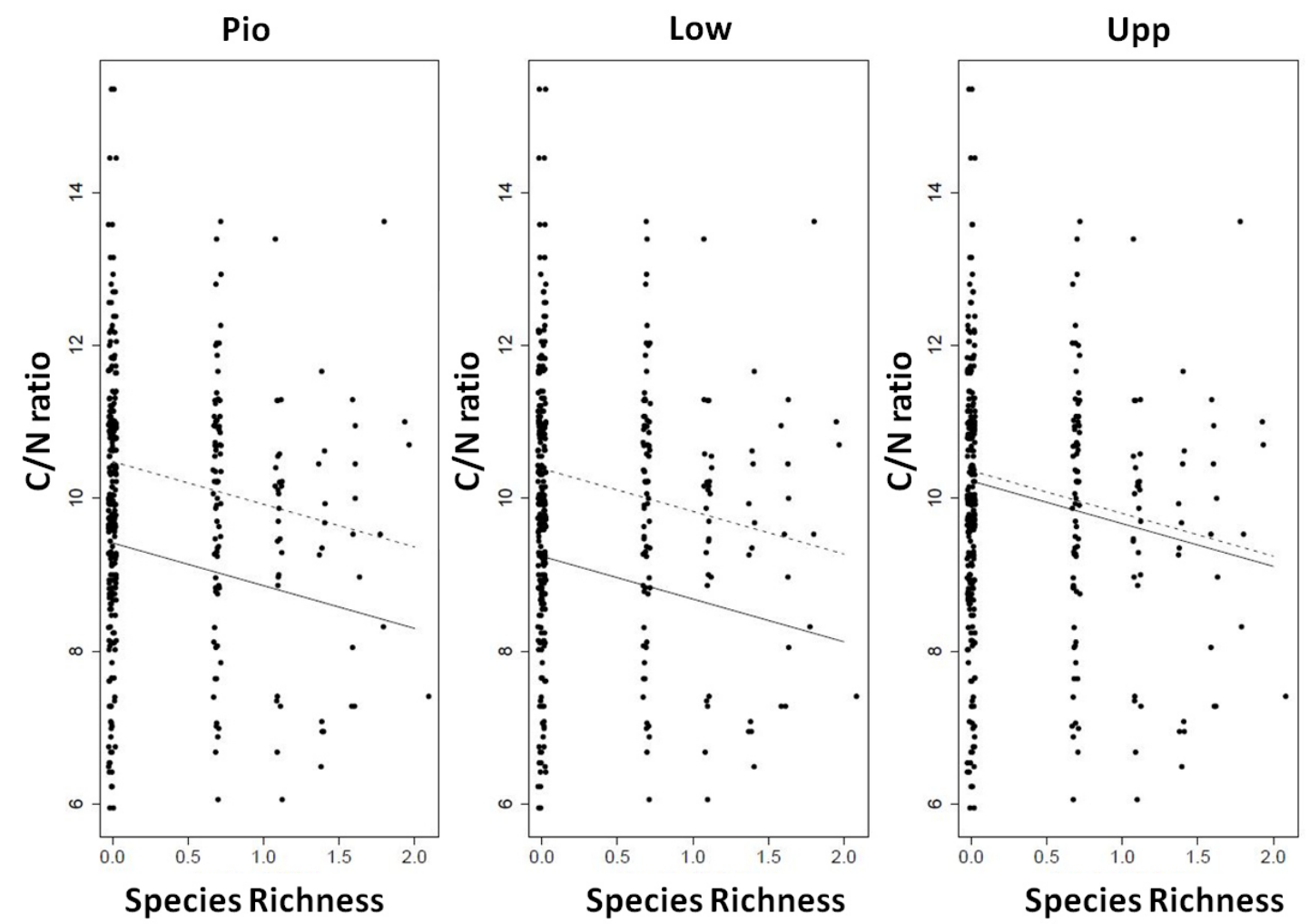

Figure 3.8 Predicted development of the $\mathrm{C} / \mathrm{N}$-ratio from species richness of 11 most abundant maggot species. Our lme model confirms a significant negative effect of species richness on the C/N-ratio (SM = solid, $\mathrm{EI}=$ dashed).

on top of the soil, the differences between SM and EI are trending from absent (Pio) to marginal (Low) to significant (Upp) with SM having higher $\mathrm{C} / \mathrm{N}$-values compared to EI. In Upp, the difference is two units in the C/N-ratio (11 to 9).

Regarding the $\mathrm{P}_{\mathrm{ex}}$-data, our models show no clear differences between the salt marsh zones over the two-week period of decomposition. Low and Upp are very stable with no clear trend observable (data not shown).

The C/N-ratio is significantly negative proportional towards species number considering all time periods of carcass decay (Figure 3.8). When species number is low, the $\mathrm{C} / \mathrm{N}$-ratio is at its maximum (10). With an increasing number of species, the total $\mathrm{N}$ rises by $10 \%$ compared to a fixed value of $\mathrm{C}$ leading to a $\mathrm{C} / \mathrm{N}$-ratio of 9 . A similar trend is visible in context with the abundance of maggots beneath and inside the decomposing carcass in combination with $\mathrm{C} / \mathrm{N}$ (data not shown). Again, a negative relationship is derived by our model regarding an increasing abundance of maggots and a decreasing $\mathrm{C} / \mathrm{N}$-ratio in the soil. In comparison with two other models (maggot abundance and abundance of the three most abundant maggot species), AICc of the species richness' linear mixed effect models fit best (AICc=1349.65). Our model 
highlighted maggot species richness as the main explanatory variable (DF=275, $t=-$ 3.835, $\mathrm{p}<0.001$ ) and maggot abundance as second placed model fit (AICc=1351.09). Considered fixed effects zone, plot and the interaction term of zone and plot were not significantly influencing the soil C/N-ratio.

\subsection{Discussion}

This study is among the first to unravel complex animal decomposition processes in a highly disturbed barrier island environment. Our results show that disturbances in salt marsh systems can cause shifts in basic ecosystem services like decomposition in a higher magnitude than naturally occurring differences between salt marsh zones. In early successional habitats, represented by the EI, animal decay was slower compared to SM plots. The decomposition process was mainly driven by eleven maggot species, three of which contributed the most (Table 3.2). In comparison to other experiments, which have been conducted regularly with whole carcasses from frog up to moose in the terrestrial environment (Parmenter \& MacMahon, 2009; Barton et al., 2013; Barton et al., 2016), maggots have the most important impact on animal decay. Our experiment took place in autumn, when population sizes of beetles are usually low, while fly populations still occur in large numbers. This is in accordance with studies in which fly maggots had the highest impact on animal decay compared to other decay-related taxa (Farwig et al., 2014). Our observations focused on the decay of soft tissue - which allows the steepest biomass reduction per time (Parmenter \& MacMahon, 2009). We found a biomass loss of up to 80\% in Upp-SM plots within the 14 days of decay. Pio and Low were very similar in their amount of biomass loss over time compared to Upp (supporting our first hypothesis). In isolated plots such as the EI, no significant differences were observed between the habitat zones. As habitat fragmentation (isolation) leads to biodiversity loss (Tscharntke et al., 2002; Didham, 2010; Isbell, 2015) and simplification of food webs and decomposition processes (Haddad et al., 2015), our analyses suggest that disturbance resulting from habitat isolation (e.g. in our study: higher sun exposition or soil desiccation), can strongly influence ecosystem functions such as decomposition.

Although our experiment is on the edge between definite terrestrial and marine habitats, the occurrence of animal decomposition related taxa is closer to 
terrestrial studies (Parmenter \& MacMahon, 2009; Farwig et al., 2014; Figure 3.4). When terrestrial decomposing communities transform carcasses within several weeks or months and nutrients are rapidly recycled by primary producers (Payne \& Moore, 2006), the interplay of marine zones and primary productivity takes much more time (Beasley, et al., 2012). In our setting, orders like Acari, Brachycera, Coleoptera and Collembola have been found on and beneath our experimental carcass. Amphipods (Crustacea), a special taxon for marine habitats, occurred, but had no significant influence. During the decomposition, carcass dwelling maggot species had the highest abundance (Figure 3.4). Community structure of maggots differed between our plot settings: Hydrotaea dentipes, Scatophaga stercoraria and Spelobia luteilabris emerged as the most abundant species and competed along our marine-terrestrial gradient (Figure 3.5). While Scatophaga stercoraria was the most abundant species in Pio, it was superseded by Hydrotaea dentipes towards higher salt marsh elevations. On the other hand, Spelobia luteilabris maintained its proportion in all zones. Interestingly, both $H$. dentipes and $S$. stercoraria are not obligate carcass related fly taxa and colonised our carcasses most likely by accident (Skidmore, 1985; Laurence, 1954). Due to their commonly colonised substrate, S. stercoraria maggots are solitary individuals which are able to linger inside a cowpat for hours by sealing their spiracles (Laurence, 1954). This is an important aspect, considering their successfully maintained highest proportion in Pio. In comparison, Hydrotaea dentipes are normally developing in rotten plant detritus and are forming maggot balls from the second and third larval instar on. Ball formation has an interspecific outcompeting effect on other species and additionally protects the best tissue for maggots by local heat production and local production of species specific toxins (Skidmore, 1985). As H. dentipes could not withstand daily tidal events by shutting down their spiracles for a longer period of time, their strategy is viable only in more terrestrial habitats.

Our results support aspects of the trophic theory of island biogeography (TTIB). According to Gravel and colleagues (2011), predatory species display a broader range of trophic diets on small islands (in their study: Adirondack lakes, Canada) compared to larger islands. Besides the focus on predatory species, our results support that also on a decomposer level, trait based TTIB could influence species distribution. Instead of a food resource that must be hunted by predators, we 
displayed a short time occurring food resource which is more easily accessible for several species. In comparison, our EI plots represent smaller and isolated islands. Here, the proportion of S. stercoraria was much smaller compared with SM plots - in contrast, Hydrotaea dentipes had a higher proportion of occurrence in EI plots. These findings support our second hypothesis. Additionally, the dung midge Rhegmoclematini gen. sp. was only slightly present on SM plots, whereas on EI plots, they occurred in much larger numbers (Figure 3.5). According to other studies (Gravel et al., 2011; Jacquet et al., 2017), species with a broader range of trophic substrates colonise smaller island patches easier than species with a smaller trophic range.

With regard to the nutrient status of the soil, our models show a clear relationship between the $\mathrm{C} / \mathrm{N}$-ratio and time of decomposition. In the process of decay, body fluids leave the decomposing carcass (Dent et al., 2004). These liquids are rich in proteins hence enrich the nearby soil with N (Hopkins \& Wiltshire, 2000). As the decay progresses, there is a gradual shift in release from very easily decomposable compounds to more recalcitrant substrates and less moisture (Carter et al., 2007). The model accounts for this by logarithmic approximation forming a "plateau" at the end of decomposition (Figure 3.7).

In Upp, we observed a distinct steeper function for EI than for SM. This can be accounted to a less disturbed ecosystem in SM compared to EI: In a natural upper salt marsh zone, we expect to find evidence for competition for the most limited nutrient in the system (in his case: N) (Levine et al., 1998; Bertness, 1991). The decline in C/N on SM-Upp plots is hampered due to simultaneous uptake by plants and microorganisms which compete for $\mathrm{N}$ (Dent et al., 2004). On EI-Upp, there is a similar trend as in Low and Pio. This is an indication that the system still faces specialistrather than competition-favoured conditions and hence demand for $\mathrm{N}$ is low compared to a major competition-based system (Keddy, 1990; Cloern, 2001). The extreme boundary conditions which govern in Pio, Low and partially in Upp not only contribute passively to decline the $\mathrm{C} / \mathrm{N}$-ratio, but also directly impact on nutrient availability: When leaching from the decomposing carcass, $\mathrm{N}$ diluted in body fluids is highly mobile (Dent et al., 2004). Hence, a highly enriched point of $\mathrm{N}$-fertilisation (CDI: Cadaver Decomposition Island; Carter et al., 2007) will get washed away very fast with the next cycle of inundation. On EI-Upp, the whole system was artificially 
transferred into an elevation with less inundation enhancing the possibility to be stored inside the sediment. Furthermore, with a higher time of exposure, microorganisms have more time to trap free $\mathrm{N}$ or labile protein-bound $\mathrm{N}$ in their anabolism during advanced decay (Vass et al., 1992).

The absence of effects on the C/N-ratio in Pio and Low between planted and non-planted plots can mostly be accounted to a lack of importance of plant-based decomposition processes within the time period of our experiment. This effect is masked by an up to three times faster carrion decomposition (Parmenter \& MacMahon, 2009). Moreover, the time of our experiment was too short for plant detritus decomposition to be relevant. Hemminga \& Buth (1991) estimated decomposition rates of halophytes typical for European salt marshes at app. $0.3 \%$ dry-mass loss per day. Mass loss rates during our cadaver-based experiment were much higher. The minor visible difference in the $\mathrm{C} / \mathrm{N}$-ratio in Upp between planted and non-planted plots over the time of decomposition is most likely again not explainable by input of plant-based organic matter (Figure 3.7B). On the contrary, this can be explained by selective uptake of $\mathrm{N}$ by plants and microorganisms in an $\mathrm{N}$ limited environment as found in Upp (Levine et al., 1998; van Wijnen \& Bakker, 1999). We suppose that microorganisms in planted Upp plots are more likely to outcompete specialists for $\mathrm{N}$ compared to non-planted Upp plots since fluctuations in soil moisture or temperature are less extreme in clayey sods compared to pure sand (Schaeffer \& Schachtschabel, 1992; Pechal, 2013). This way, immobilisation of $\mathrm{N}$ is higher in planted Upp plots leading to a higher C/N-ratio at the end of decomposition. Moreover, in a sand dominated soil as found in Upp non-planted plots, gaseous exchange is likely to assist decomposition processes as opposed to dense planted sods found in planted Upp plots which hamper aeration slowing down decomposition processes (Hare, 1988; Janaway, 1997).

When zones are pooled, we can discriminate the elevation factor from our model (Figure 3.7C). This way, the isolated differences between planted and nonplanted plots can be examined. The strong decline in the $\mathrm{C} / \mathrm{N}$-ratio on planted SM plots compared to non-planted SM plots can be explained by an enhanced retention of released $\mathrm{N}$ in sods compared to bare sand: Ammonia volatilisation potential is lower in soils with a higher proportion of clay particles since they can bind $\mathrm{NH}^{4+}$ via electrostatic attraction (Cameron et al., 2013). Another reason for the stable situation 
in the C/N-ratio on non-planted SM plots was the removal of sods from the environment: The system is not capable of preserving the diluted $\mathrm{N}$ from the carcass from being washed away by tides (Valiela \& Teal, 1979). Hence, a localised high peak of nutrient supply does not affect the surrounding environment. Compared to nonplanted EI plots, our model indicates another mechanism: The strong drop in the $\mathrm{C} / \mathrm{N}$-ratio on non-planted EI plots is a consequence of the high input of $\mathrm{N}$ over a very short time. Against a background of an OM-depleted, sandy environment this leads to an indirect $\mathrm{N}$ enrichment in relation to $\mathrm{C}$ on non-planted EI. This pattern is not that concise on EI planted plots since here the system has a higher background $\mathrm{OM}$ content masking the $\mathrm{N}$-rich input from the carcass to a certain degree.

Without the consideration of decomposition time, we can examine background effects concerning $\mathrm{C} / \mathrm{N}$-dynamics in different salt marsh zones and plot identity. Using this approach, a strong depletion of $\mathrm{N}$-fractions on planted EI compared to SM becomes visible. Although in all zones the N-loss is similar, the background mechanisms are zone specific. In planted Upp plots, we assume a biotic variable (here: higher plant density on SM compared to EI) to explain the difference between SM and EI plots. However, the disparity in Pio and Low is higher, due to abiotic variables such as temperature and oxygen supply which differ greatly and might have had a greater impact than biotic variables in our system. In an isolated EI, sunshine can heat up an island easier than a well-integrated system as found for SM. In contrast, the temperature declines faster at night on EI as compared to SM due to a smaller bulk soil body. This leads to fissures within the transplanted sods on the island allowing an improved oxygen supply (Dent, 1986). Both factors, higher temperature and better oxygen status of the soil, promote higher potential of nitrification and ultimately a higher risk for $\mathrm{NO}_{3}-$ leaching in case of tidal inundation (Cameron et al., 2013). In Pio, a certain amount of N-loss might also be caused by gaseous emissions via $\mathrm{N}_{2}$ as a product of denitrification. The latter process is especially enhanced in water logged conditions in conjunction with a substantial amount of SOM as found in Pio (Cameron et al., 2013).

When decomposition time is pooled, differences in the $\mathrm{C} / \mathrm{N}$-ratio between non-planted EI and non-planted SM are absent (Pio) or small (Low) (Figure 3.7D). Due to the sandy texture of the topsoil in this treatment, water holding capacity is lower than in natural sods from the salt marsh system. On SM plots, the water 
gradient between plots and surrounding soil is being equalised via lateral water flux. However, this cannot occur on isolated EIs. Moreover, due to the geographic distance, seed dispersal is hampered on EI but not on SM. Both factors allow a denser plant cover especially in Upp-SM plots as compared to Upp-EI plots. As a consequence, $\mathrm{N}$ gets taken up by plants on a greater scale on non-planted SM Upp compared to nonplanted EI Upp.

Results concerning the interplay between $\mathrm{C} / \mathrm{N}$-ratio and maggot species richness (in support for hypothesis 3) indicate that $\mathrm{N}$-uptake by plants is not fast enough to account for decomposition derived N. This accumulation in the soil is similar to a short-term fertiliser and is also spreading around the actual carcass position (Parmenter \& MacMahon, 2009). Therefore, a fast microbial turnover rate can be expected within this early CDI (Benninger, 2008). Increased microbial activity thus also increases availability of plant growth limiting nutrients such as N. This pattern generally appeared through all plot- and treatment-types and could therefore be assumed to be a general process. Our results suggest, that the $\mathrm{C} / \mathrm{N}$-ratio decreases from Pio to Upp in SM-plots due to the fact that $\mathrm{N}$ leaches from the carcass and hence the lower $\mathrm{C} / \mathrm{N}$-ratio. The higher the plot elevation from sea level, the more $\mathrm{N}$ is taken up due to higher competition in $\mathrm{N}$ uptake in plants (Crain, 2004). In comparison, EI are highly disturbed and therefore, nitrogen uptake by Upp plants is hampered. Then nitrogen should accumulate easier in Upp of EI due to less regular flooding and dilution by sea-organic matter.

Overall, our study provides evidence that animal decay as an important ecosystem function should be considered in nature conservation measures. Until now, due to risk of botulism, large decaying animals (mammals, birds) are taken from conservation areas when they easily could be accessed by tourists, children or pets. Animal decomposition enhances local biodiversity and could therefore be understood as important process to maintain, for instance, specific fly species such as Scatophaga litorea or Scatopse litorea. Decomposition processes and local biodiversity enhancement stabilise other ecosystem functions (Eisenhauer \& Schädler, 2011) and therefore, play an important role in the protection of habitats. Thus, it might be possible, to protect humans and pets from the risk of infections by surrounding decaying animals with broad-meshed fences allowing decomposing species to access decaying tissue but separating them from unwanted human access. 
In conclusion, our experiment demonstrated that nutrient release following animal decomposition depends on species richness of decomposing maggots and, to a lesser degree, on plot identity.

\section{References}

Anderson, G. S., \& Bell, L. S. (2016). Impact of marine submergence and season on faunal colonization and decomposition of pig carcasses in the salish sea. PLoS ONE, 11(3), e0149107.

Bährmann, R. (2008). Bestimmung wirbelloser Tiere. Munich: Elsevier

Balke, T., Lohmus, K., Hillebrand, H., Zielinski, O., Haynert, K., Meier, D., Hodapp, D., Minden, V., \& Kleyer, M. (2017). Experimental salt marsh islands: a model system for novel metacommunity experiments. Estuarine, Coastal and Shelf Science, 198(A), 288-298.

Barton, P. S., McIntyre, S., Evans, M. J., Bump, J. K., Cunningham, S. A., \& Manning, A. D. (2016). Substantial long-term effects of carcass addition on soil and plants in a grassy eucalypt woodland. Ecosphere, $7(10)$.

Barton, P. S., Cunningham, S. A., Macdonald, B. C. T., McIntyre, S., Lindenmayer, D. B., \& Manning, A. D. (2013). Species traits predict assemblage dynamics at ephemeral resource patches created by carrion. PLoS ONE, 8(1), e53961.

Beasley, J. C., Olson, Z. H., \& DeVault, T. L. (2012). Carrion cycling in food webs: comparisons among terrestrial and marine ecosystems. Oikos, 121(7), 10211026.

Benninger, L. A., Carter, D. O., \& Forbes, S. L. (2008). The biochemical alteration of soil beneath a decomposing carcass. Forensic Science International, 180(2-3), 7075 .

Bertness, M. D. (1991). Interspecific interactions among high marsh perennials in a New England salt marsh. Ecology, 72(1), 125-137.

Blume, H. P., Stahr, K., \& Leinweber, P. (2011). Bodenkundliches Praktikum: Eine Einführung in pedologisches Arbeiten für Ökologen, Land-und Forstwirte, Geound Umweltwissenschaftler. Springer-Verlag

Burnham, K. P., \& Anderson, D. R. (2004). Multimodel inference: understanding AIC and BIC in model selection. Sociological methods \& research, 33(2), 261-304. 
Cameron, K. C., Di, H. J., \& Moir, J. L. (2013). Nitrogen losses from the soil/plant system: a review. Annals of Applied Biology, 162(2), 145-173.

Carter, D. O., Yellowlees, D., \& Tibbett, M. (2007). Cadaver decomposition in terrestrial ecosystems. Naturwissenschaften, 94(1), 12-24.

Cloern, J. E. (2001). Our evolving conceptual model of the coastal eutrophication problem. Marine ecology progress series, 210, 223-253.

Crain, C. M., Silliman, B. R., Bertness, S. L., \& Bertness, M. D. (2004). Physical and biotic drivers of plant distribution across estuarine salinity gradients. Ecology, 85(9), 2539-2549.

Dent, D. L. (1986). Acid sulphate soils: a baseline for research and development. International Institute for Land Reclamation and Improvement (ILRI), Wageningen, The Netherlands.

Dent, B. B., Forbes, S. L., \& Stuart, B. H. (2004). Review of human decomposition processes in soil. Environmental Geology, 45(4), 576-585.

Didham, R. K. (2010). Ecological consequences of habitat fragmentation. Encyclopedia of Life Sciences (ELS). John Wiley \& Sons Ltd., Chichester, 1-11.

Dunger, W., \& Fiedler, H. J. (1999). Methoden der Bodenbiologie Bestimmungstafeln. Gustav-Fischer-Verlag

Eisenhauer, N., \& Schädler, M. (2011). Inconsistent impacts of decomposer diversity on the stability of aboveground and belowground ecosystem functions. Oecologia, 165(2), 403-415.

Farwig, N., Brandl, R., Siemann, S., Wiener, F., \& Mueller, J. (2014). Decomposition rate of carrion is dependent on composition not abundance of the assemblages of insect scavengers. Oecologia, 175(4), 1291-1300.

Folmer, O., Black, M., Hoeh, W., Lutz, R., \& Vrijenhoek, R. (1994). DNA primers for amplification of mitochondrial cytochrome $\mathrm{c}$ oxidase subunit I from diverse metazoan invertebrates. Molecular Marine Biology and Biotechnology, 3(5), 294-299.

Gravel, D., Massol, F., Canard, E., Mouillot, D., \& Mouquet, N. (2011). Trophic theory of island biogeography. Ecology Letters, 14(10), 1010-1016.

Haddad, N. M., Brudvig, L. A., Clobert, J., Davies, K. F., Gonzalez, A., Holt, R. D., Lovejoy, T. E., Sexton J. O., Austin, M. P., Collins, C. D., Cook, W. M., Damschen, E. I., Ewers, R. M., Foster, B. L., Jenkins, C. N., King, A. J., Laurance, W. F., Levey, D. J., 
Margules, C. R., Melbourne, B. A., Nicholls, A. O., Orrock, J. L., Song, D.-X., \& Townshend, J. R. (2015). Habitat fragmentation and its lasting impact on Earth's ecosystems. Science Advances, 1(2), e1500052.

Hadziavdic, K., Lekang, K., Lanzen, A., Jonassen, I., Thompson, E. M., \& Troedsson, C. (2014). Characterization of the 18s rRNA gene for designing universal eukaryote specific primers. PLoS ONE, 9(2), 87624.

Hall, T. A. (1999). BioEdit: a user-friendly biological sequence alignment editor and analysis program for Windows 95/98/NT. Nucleic Acids Symposium Series (Vol. 41, No. 41, pp. 95-98). London: Information Retrieval Ltd., c1979-c2000.

Hare, P. E. (1988). Organic geochemistry of bone and its relation to the survival of bone in the natural environment. Fossils in the making: Vertebrate taphonomy and paleoecology, University of Chicago Press.

Hemminga, M. A., \& Buth, G. J. C. (1991). Decomposition in salt marsh ecosystems of the SW Netherlands: the effects of biotic and abiotic factors. Vegetatio, 92(1), 73-83.

Hopkins, D.W., Wiltshire, P.E.J., \& Turner B.D. (2000). Microbial characteristics of soils from graves: An investigation at the interface of soil microbiology and forensic science. Applied Soil Ecology, 14, 283-288

Jacquet, C., Mouillot, D., Kulbicki, M., \& Gravel, D. (2017). Extensions of Island Biogeography Theory predict the scaling of functional trait composition with habitat area and isolation. Ecology Letters, 20(2), 135-146.

Janaway, R. C. (1996). The decay of buried human remains and their associated materials. Studies in crime: an introduction to forensic archaeology, 58, 85.

Keddy, P.A. (1990). Competitive hierarchies and centrifugal organization in plant communities. Perspectives on Plant Competition, pp. 266-290. Academic Press, San Diego.

Kempson, D., Lloyd, M., Ghelardi, R., 1963. A new extractor for woodland litter. Pedobiologia, 3: 1-21.

Laurence, B. R. (1954). The larval inhabitants of cow pats. Journal of Animal Ecology, 23(2), 234-260.

Levine, J. M., Brewer, J. S., \& Bertness, M. D. (1998). Nutrients, competition and plant zonation in a New England salt marsh. Journal of Ecology, 86(2), 285-292. 
Losos, J. B., \& Ricklefs, R. E. (2009). The theory of island biogeography revisited. Princeton University Press.

MacArthur, R., \& Wilson, E. O. (1967). The theory of island biogeography. Princeton: Princeton University Press.

Marcelino, J. A. P., Giordano, R., Borges, P. A. V., Garcia, P. V., Soto-Adames, F. N., \& Soares, A. 0. (2016). Distribution and genetic variability of staphylinidae across a gradient of anthropogenically influenced insular landscapes. Bulletin of Insectology, 69(1), 117-126.

Niedringhaus, R., Haeseler, V., \& Janiesch, P. (2008). Die Flora und Fauna der Ostfriesischen Inseln - Einführung in das Projekt „Biodiversität im Nationalpark Niedersächsisches Wattenmeer" - Schriftenreihe Nationalpark Niedersächsisches Wattenmeer, 11.

Olson, J. S. (1963). Energy storage and the balance of producers and decomposers in ecological systems. Ecology, 44(2), 322-331

Oosterbroek, P., \& Hurkmans, W. E. G. (2006). The European families of the Diptera: identification, diagnosis, biology (Vol. 583). Utrecht: KNNV publishing, 205.

Parmenter, R. R., \& MacMahon, J. A. (2009). Carrion decomposition and nutrient cycling in a semiarid shrub- steppe ecosystem. Ecological Monographs, 79(4), 637-661.

Payne, L. X., \& W. Moore, J. (2006). Mobile scavengers create hotspots of freshwater productivity. Oikos, 115(1), 69-80.

Pechal, J. L., Crippen, T. L., Tarone, A. M., Lewis, A. J., Tomberlin, J. K., \& Benbow, M. E. (2013). Microbial community functional change during vertebrate carrion decomposition. PloS one, 8(11), e79035.

Richards, S. L., Connelly, C. R., Day, J. F., \& Hope, T. (2015). Arthropods associated with carrion in a salt marsh habitat in southeastern Florida. Florida Entomologist, 98(2), 613-619.

Santos, A. M., Field, R., \& Ricklefs, R. E. (2016). New directions in island biogeography. Global Ecology and Biogeography, 25(7), 751-768.

Schaeffer, F., \& Schachtschabel, P. (1992). Lehrbuch der Bodenkunde, 13. Aufl., Enke.

Schüller, H. (1969). Die CAL-Methode, eine neue Methode zur Bestimmung des pflanzenverfügbaren Phosphates in Böden. Journal of Plant Nutrition and Soil Science, 123(1), 48-63. 
Skidmore, P. (1985). The biology of the Muscidae of the world (Vol. 29). Springer Science \& Business Media.

Streif, H. (1990). Das ostfriesische Küstengebiet: Nordsee, Inseln, Watten u. Marschen. (2. Aufl., Bd. 57). Bornträger.

Szpila, K. (2009). Key for the identification of third instars of european blowflies (Diptera: Calliphoridae) of forensic importance. Current Concepts in Forensic Entomology, 43-56.

Tabor, K. L., Brewster, C. C., \& Fell, R. D. (2004). Analysis of the successional patterns of insects on carrion in southwest Virginia. Journal of Medical Entomology, 41(4), 785-795.

Tscharntke, T., Steffan-Dewenter, I., Kruess, A., \& Thies, C. (2002). Characteristics of insect populations on habitat fragments: a mini review. Ecological research, 17(2), 229-239

Valiela, I., \& Teal, J. M. (1979). The nitrogen budget of a salt marsh ecosystem. Nature, 280(5724), 652.

Van Wijnen, H., \& Bakker, J. (1999). Nitrogen and phosphorus limitation in a coastal barrier salt marsh: the implications for vegetation succession. Journal of Ecology, 87(2), 265-272.

Vass, A. A., Bass, W. M., Wolt, J. D., Foss, J. E., \& Ammons, J. T. (1992). Time since death determinations of human cadavers using soil solution. Journal of Forensic Science, 37(5), 1236-1253

Whittaker, R. J., Rigal, F., Borges, P. A., Cardoso, P., Terzopoulou, S., Casanoves, F., Pla, L., Guilhaumon, F., Ladle R.J., \& Triantis, K.A. (2014). Functional biogeography of oceanic islands and the scaling of functional diversity in the Azores. PNAS, 111(38), 13709-13714

Yang, L. H., Bastow, J. L., Spence, K. O., \& Wright, A. N. (2008). What can we learn from resource pulses? Ecology, 89(3), 621-634. 


\section{Supplementary material}

Table S3.1 Soil extraction protocol changes following Kempson et al. (1963)

\begin{tabular}{l|cc} 
Day & Temperature $\left[{ }^{\circ} \mathbf{C}\right]$ & Duration $[\mathbf{h}]$ \\
\hline 1 & 25 & 24 \\
2 & 30 & 24 \\
3 & 35 & 24 \\
4 & 40 & 24 \\
5 & 45 & 24 \\
6 & 50 & 24 \\
7 & 55 & 24 \\
8 & 55 & 24
\end{tabular}

\section{S2 Complete barcoding protocol}

\section{DNA extraction}

DNA from samples was extracted using the DNeasy Blood \& Tissue Kit (Qiagen). At first, samples were weighted and a maximum of $50 \mathrm{mg}$ of each sample (larva, pupa or imago) were transferred to a $2 \mathrm{ml}$ microcentrifuge tube (Eppendorf) and homogenised with a glass mortar in $180 \mu \mathrm{l}$ PBS buffer. Samples weighting more than $50 \mathrm{mg}$ were cut with a scalpel. When cutting imagines, only the thorax was used. Afterwards, $20 \mu$ Proteinase K (Qiagen) and $200 \mu$ l AL buffer were added, vortexed thoroughly and incubated for $10 \mathrm{~min}$ at $56^{\circ} \mathrm{C}$. Not fully dissolved samples were incubated for another $10 \mathrm{~min}$. After incubation $200 \mu \mathrm{l}$ ethanol (96-100\%) were added and vortexed thoroughly. Subsequently, the mixture was pipetted into the DNeasy Mini spin column placed in a $2 \mathrm{ml}$ collection tube and centrifuged for $1 \mathrm{~min}$ at 8,000 rpm. Flow-through and collection tube were discarded. The columns were placed in a new collections tube and $500 \mu \mathrm{l}$ Buffer AW1 were added and centrifuged for $1 \mathrm{~min}$ at 8,000 rpm. The columns were placed again in new collection tubes and 
$500 \mu \mathrm{l}$ Buffer AW2 were added and centrifuged for 3 min at 13,200 rpm. Flowthrough and provided collection tubes were discarded after each step. At last, the columns were placed in a $2 \mathrm{ml}$ microcentrifuge tube and $50 \mu \mathrm{l}$ Buffer AE were pipetted directly in the center of the membrane, incubated for $5 \mathrm{~min}$ at room temperature and centrifuged for $1 \mathrm{~min}$ at 8,000 rpm. Flow-through and columns were discarded and eluted DNA was stored at $-20^{\circ} \mathrm{C}$.

Because the samples for Hydrotaea dentipes, Nemotelus notatus, Haematopota pluvialis and an unidentified pupa (pupa1) were small, inset of chemicals were cut in half to ensure a possible higher concentration of DNA for the second extraction.

\section{PCR}

The PCR was used to amplify a $730 \mathrm{bp}$ sequence from the COI region. The primer pair was modified after universal primers LCO1490 (up) and HCO2198 (low) (Folmer et al., 1994) and can be seen in Table 3.1. When COI primers showed no success, modified 18S primers (after Hadziavdic et al., 2014) were used for amplification (Table 3.1).

PCR amplifications were carried out in a final reaction volume of $25 \mu \mathrm{l}$ consisting of $1 \mu \mathrm{l}$ DNA sample, $5 \mu \mathrm{l} \mathrm{MyTaq}{ }^{\text {TM }}$ Reaction Buffer $5 \mathrm{x}, 0.2 \mu \mathrm{MyTaq}^{\text {TM }} \mathrm{MS}$ DNA Polymerase (both Bioline), $1 \mu \mathrm{l}$ of a $20 \mu \mathrm{M}$ working solution of forward and reverse Primer and $16.8 \mu \mathrm{l}$ of RNase free Water (Qiagen). PCR was performed on a DNA Thermal Cycler type Mastercycler® Personal (Eppendorf) using the followings conditions for COI PCR: $95^{\circ} \mathrm{C}$ for $5 \mathrm{~min}$ and 30 cycles of $94^{\circ} \mathrm{C}$ for $1 \mathrm{~min}, 55^{\circ} \mathrm{C}$ for $1 \mathrm{~min}$ and $72^{\circ} \mathrm{C}$ for $1 \mathrm{~min}$. Annealing temperature was adjusted to $51^{\circ} \mathrm{C}$ and $48^{\circ} \mathrm{C}$, respectively for samples with no amplification success at $55^{\circ} \mathrm{C}$. Reamplification of PCR products used adjusted conditions of 20 cycles and $45^{\circ} \mathrm{C}$ annealing temperature. 18S PCR conditions used the same conditions, but $65^{\circ} \mathrm{C}$ annealing temperature. Amplification success was visualised via gel electrophoresis with $2 \% \quad 2.5 \%$ respectively) agarose gel (110 V for 40 min; Low Molecular Weight DNA Ladder; New England Biolabs Inc.). PCR products were purified using $7.5 \mu \mathrm{l}$ of PCR reactions $2.5 \mu \mathrm{l}$ (1U) rAPid Alkaline Phosphatase (Roche Inc.) and $1 \mu \mathrm{l}(1 \mathrm{U})$ Exonuclease I (New England Biolabsinc), followed by incubation at $37^{\circ} \mathrm{C}$ for $60 \mathrm{~min}$ and $75^{\circ} \mathrm{C}$ for $15 \mathrm{~min}$. Reamplification PCR products were purified using $5 \mu \mathrm{l}$ of PCR reaction and $2 \mu \mathrm{l}$ of 
Chapter 3

ExoSAP-IT ${ }^{\circledR}$ Express (Affymetrix), followed by incubation at $37^{\circ}$ for 4 min and $80^{\circ} \mathrm{C}$ for $1 \mathrm{~min}$.

\section{Sequencing}

Sequencing reactions were carried out with the BigDye ${ }^{\circledR}$ Terminator (BDT) v1.1 Cycle Sequencing Kit (Applied Biosystems). The final reaction volume was $20 \mu \mathrm{l}$ consisting of $2 \mu \mathrm{lBDT}, 4 \mu \mathrm{l}$ Seq Buffer (5x), $0.3 \mu \mathrm{l}$ of a $20 \mu \mathrm{M}$ working solution of the reverse COI and $18 \mathrm{~S}$ Primer, respectively $\left(6.7 \mu \mathrm{l} \mathrm{H}_{2} \mathrm{O}\right.$ and $7 \mu \mathrm{l}$ PCR product). Sequencing reactions (COI and 18S) were performed on a DNA Thermal Cycler type Mastercycler ${ }^{\circledR}$ (Eppendorf) using the following conditions for COI PCR: $94^{\circ} \mathrm{C}$ for $3 \mathrm{~min}$ and $25 \mathrm{cycles}$ of $94^{\circ} \mathrm{C}$ for $30 \mathrm{sec}, 50^{\circ} \mathrm{C}$ for $15 \mathrm{sec}$ and $60^{\circ} \mathrm{C}$ for $2.5 \mathrm{~min}$ and a final elongation step at $60^{\circ} \mathrm{C}$ for $4 \mathrm{~min}$. After that, samples were cooled down to $10^{\circ} \mathrm{C}$. Sequencing products were purified using the NucleoSEQ® Kit (Macherey \& Nagel) following the manufacturer's instructions.

Capillary electrophoresis was performed on a 3500 Genetic Analyzer (Applied Biosystems) using POP-7 polymer in the capillary (36 cm array, Applied Biosystems), a customised run module and $20 \mu \mathrm{l}$ of the purified sequencing product. The sequences were analysed using the software BioEdit v7.2.5 (Hall, 1999). 


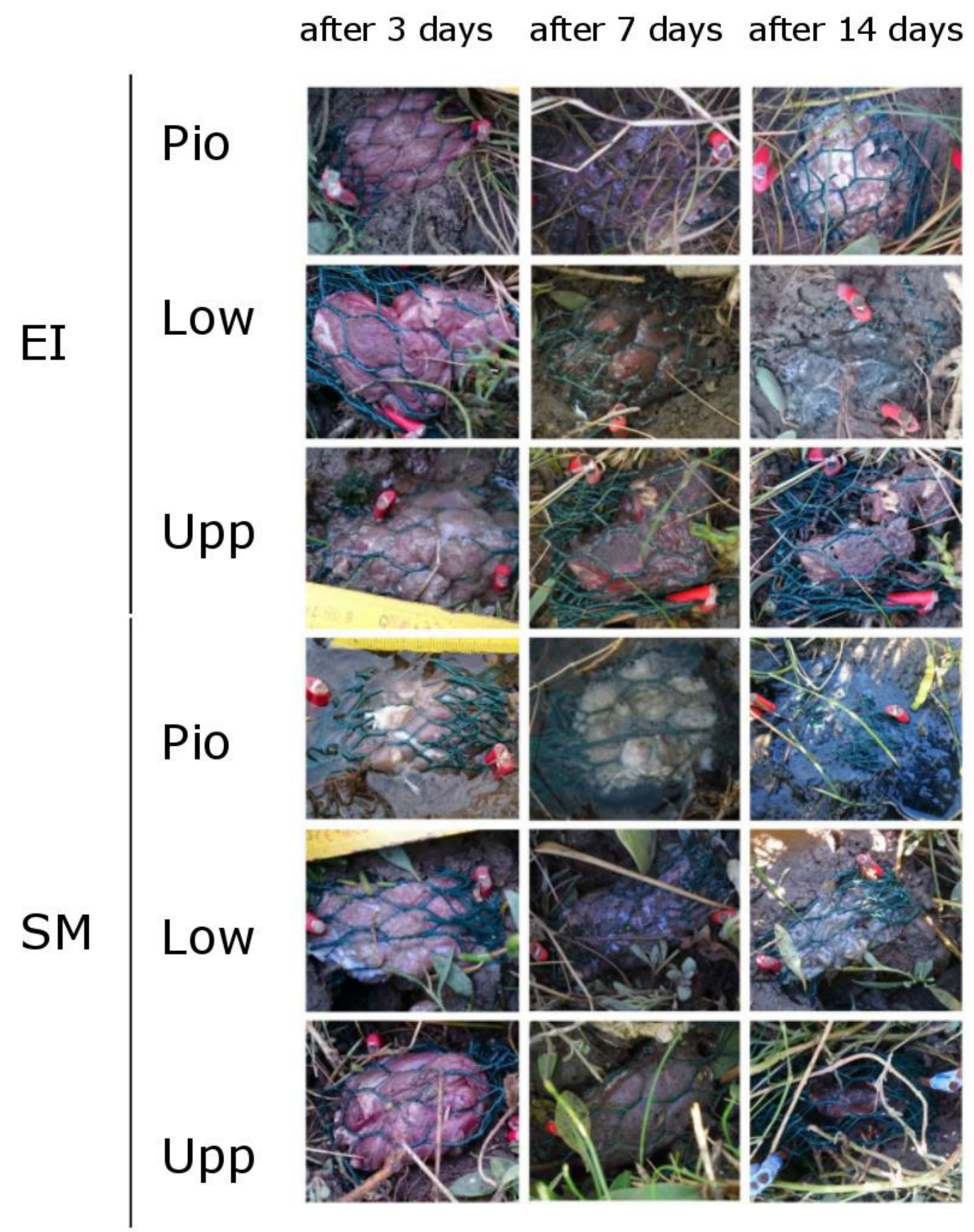

Figure S3.3 Planted plots of decomposition experiment. Decomposition of meat pieces is displayed as a timeline from left to right for the different treatments. In Pio plots, blood components are rapidly washed out resulting in a lighter meat colour after 7 days. This effect is most pronounced in SM plots. Additionally, after 14 days in transplanted Pio plots, a microbial biofilm with blackish soil elements could be observed indicating that sulfur-reducing bacteria occur in the upper soil layer. In general, meat weight reduction could be observed from meat size: In Upp plots, meat sizes were visibly reduced compared to other plots. 
Chapter 3 


\section{Chapter 4}

\section{Global-change effects on early-stage decomposition processes in tidal wetlands - implications from a global survey using standardised litter}

Peter Mueller, Lisa M. Schile-Beers, Thomas J. Mozdzer, Gail L. Chmura, Thomas Dinter, Yakov Kuzyakov, Alma V. de Groot, Peter Esselink, Christian Smit, Andrea D’Alpaos, Carles Ibáñez, Magdalena Lazarus, Urs Neumeier, Beverly J. Johnson, Andrew H. Baldwin, Stephanie A. Yarwood, Diana I. Montemayor, Zaichao Yang, Jihua $\mathrm{Wu}$, Kai Jensen, Stefanie Nolte

Published in Biogeosciences, 15, 3189-3202, 2018, https://doi.org/10.5194/bg-153189-2018

Author contributions

PM, SN, KJ, and LMSB designed the overall study; PM analysed and interpreted the data; PM wrote the initial version of the manuscript with regular comments and editing provided by LMSB, TJM, and SN; PM, LMSB, TJM, GLC, TD, YK, AVdG, PE, CS, AD'A, CI, ML, UN, BJJ, AHB, SAY, DIM, ZY, and JW designed and conducted the field studies in the respective sites and commented on an earlier version of the manuscript 


\section{Abstract}

Tidal wetlands, such as tidal marshes and mangroves, are hotspots for carbon sequestration. The preservation of organic matter (OM) is a critical process by which tidal wetlands exert influence over the global carbon cycle and at the same time gain elevation to keep pace with sea level rise (SLR). The present study assessed the effects of temperature and relative sea level on the decomposition rate and stabilisation of OM in tidal wetlands worldwide, utilising commercially available standardised litter. While effects on decomposition rate per se were minor, we show strong negative effects of temperature and relative sea level on stabilisation, as based on the fraction of labile, rapidly hydrolysable $\mathrm{OM}$ that becomes stabilised during deployment. Across study sites, OM stabilisation was 29 \% lower in low, more frequently flooded vs. high, less frequently flooded zones. Stabilisation declined by $75 \%$ over the studied temperature gradient from 10.9 to $28.5^{\circ} \mathrm{C}$. Additionally, data from the Plum Island long-term ecological research site in Massachusetts, USA, show a pronounced reduction in $\mathrm{OM}$ stabilisation by $>70 \%$ in response to simulated coastal eutrophication, confirming the potentially high sensitivity of OM stabilisation to global change. We therefore provide evidence that rising temperature, accelerated SLR, and coastal eutrophication may decrease the future capacity of tidal wetlands to sequester carbon by affecting the initial transformations of recent OM inputs to soil OM. 


\subsection{Introduction}

Tidal wetlands, such as marshes and mangroves, provide a wide array of ecosystem services that have been valued at approximately USD 10000 per hectare and year, making them some of the most economically valuable ecosystems on earth (Barbier et al., 2011; Kirwan \& Megonigal, 2013). Yet, tidal wetlands are threatened and vulnerable ecosystems, experiencing pronounced loss through global-change impacts, such as land use (Pendleton et al., 2012) and accelerated sea-level rise (SLR) (Craft et al., 2009; Crosby et al., 2016). In recent years, carbon sequestration has increasingly been recognised as an ecosystem service of tidal wetlands (Chmura et al., 2003; Mcleod et al., 2011). Here, high rates of organic matter (OM) input (from both autochthonous and allochthonous production) co-occur with reducing soil conditions and thus slow rates of decomposition, leading to long-term carbonsequestration rates that exceed those of most other ecosystem types by an order of magnitude (Mcleod et al., 2011). At the same time, suppressed decomposition and the preservation of $\mathrm{OM}$ is a primary process by which many tidal wetlands gain elevation and keep pace with rising sea level (Kirwan \& Megonigal, 2013). Consequently, global changes that decrease OM preservation in tidal-wetland soils not only affect carbon sequestration, but also decrease ecosystem stability against SLR. It is therefore critical to identify global-change factors that affect the transformation of organic inputs to stable soil OM (SOM) in tidal wetlands and to assess the magnitude of their effects.

There are multiple methods for assessing factors that influence carbon sequestration, including direct measurements of plant production, carbon stocks, accretion, and decomposition rates. Litter-bag techniques assessing the weight loss of plant material over time are probably the easiest way to measure decomposition rates in situ and have been widely used since the 1960s (Prescott, 2010). Global-scale assessments of litter decomposition have been conducted as both meta-analyses (e.g., Zhang et al., 2008) and as inter-site studies along latitudinal gradients (Berg et al., 1993; Cornelissen et al., 2007; McTiernan et al., 2003; Powers et al., 2009; Trofymow et al., 2002) in order to assess effects of climate parameters on decomposition rate. Besides abiotic or climate effects, these studies could also identify litter quality itself as an important predictor for decomposition rate (Zhang et al., 2008). Relationships 


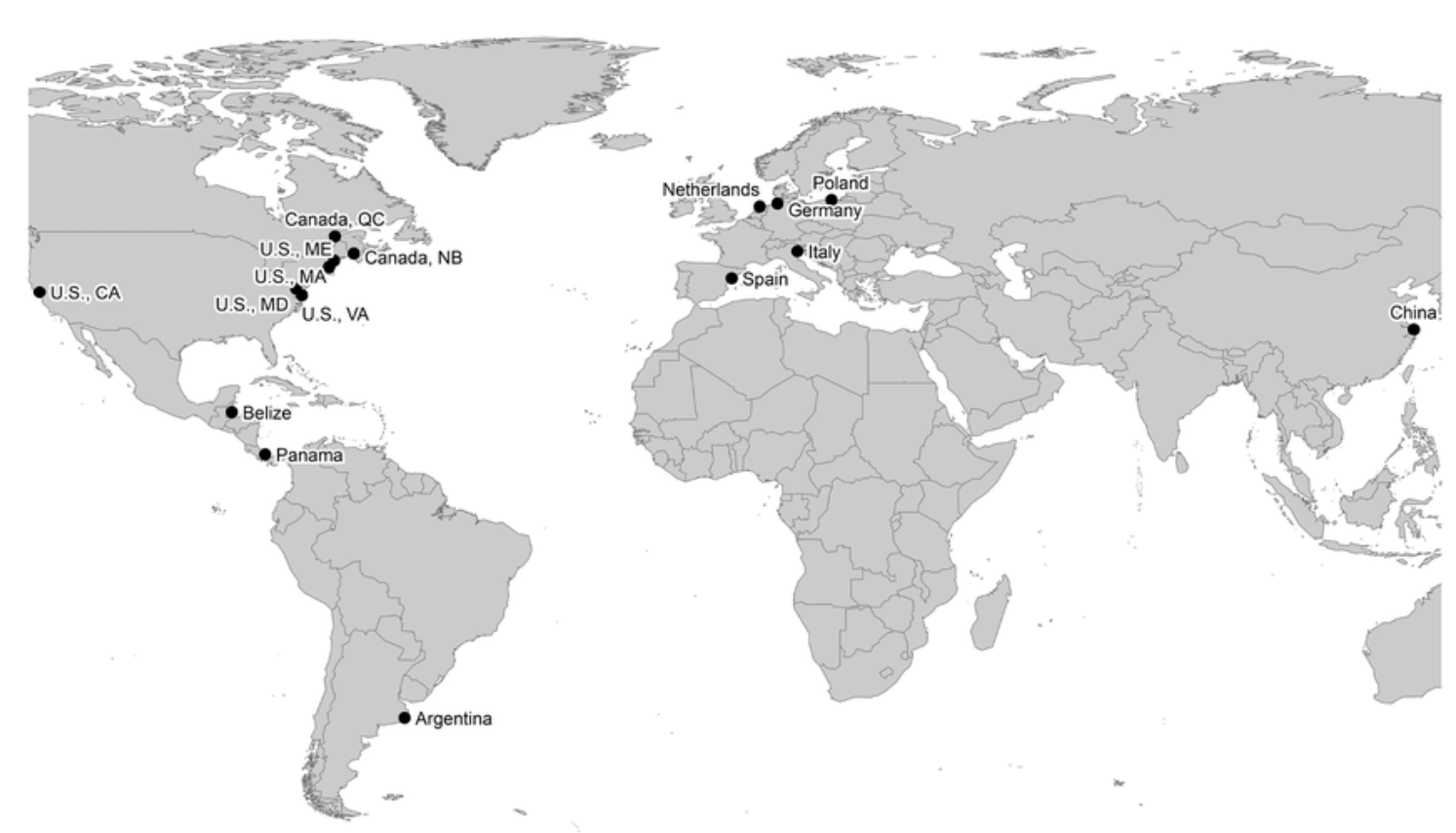

Figure 4.1 Overview map of study regions. Notes: see Table 4.1 for region and site details.

between single climate or litter-quality parameters and decomposition rate often are not linear. Instead, complex interactions between litter-quality and climate parameters seem to control litter decomposition (Zhang et al., 2008), creating challenges in separating climate from litter-quality effects and predicting the relevance of potential global-change drivers for decomposition rate. In order to separately assess environmental or climate effects on litter decomposition at a global scale, it is therefore necessary to standardise litter quality in inter-site studies. However, implications of litter-decay data for carbon sequestration need to be considered cautiously, as the link among litter-decomposition rate, SOM formation, and ultimately carbon sequestration is not straightforward (Cotrufo et al., 2013; Prescott, 2010): Because plant tissues are not resistant to decay per se, it is critical to understand their biogeochemical transformation into stable compounds that leads to the formation of SOM (i.e. stabilisation) rather than understanding the pace at which early-stage decomposition proceeds (Castellano et al., 2015; Haddix et al., 2016; Prescott, 2010). Keuskamp et al. (2013) developed an efficient approach for studying litter decomposition and $\mathrm{OM}$ transformation at a global scale, using commercially available tea as standardised material. Their Tea Bag Index (TBI) approach is based on the deployment of two types of tea that considerably differ in their OM quality.

The method allows for the determination of the decomposition rate constant (in the following referred to as decomposition rate or $k$ ) and a stabilisation factor (in 
the following referred to as stabilisation or $S$ ), which describes the fraction of labile and rapidly decomposable $\mathrm{OM}$ that becomes stabilised during deployment. In the present study, we assessed effects of the global-change factors global warming, accelerated SLR, and coastal eutrophication on both OM decomposition rate and stabilisation in tidal-wetland soils by conducting a worldwide survey using standardised litter. First, by covering a large temperature gradient of $1 \mathrm{~T}>15^{\circ} \mathrm{C}$ across sites, we aimed to capture temperature effects on $\mathrm{OM}$ decomposition rate and stabilisation, thereby improving our understanding on how global warming affects carbon turnover and ultimately sequestration in tidal wetlands. Second, by conducting paired measurements in both high and low elevated zones of tidal wetlands worldwide, we were aiming to gain insight into potential effects of accelerated SLR on carbon turnover. Despite the dominant paradigm that decomposition is inversely related to flooding, the existing literature on hydrology and SLR effects on OM decomposition in tidal wetlands yields equivocal results, which is often due to the overriding effect of OM quality on decomposition rate (Hemminga \& Buth, 1991; Kirwan et al., 2013; Mueller et al., 2016). Lastly, we used the TIDE (Trophic cascades and Interacting control processes in a Detritus-based Ecosystem) project plots of the Plum Island long-term ecological research site in Massachusetts, USA (Deegan et al., 2012), to experimentally assess both the effects of coastal eutrophication and - with respect to SLR-driven increases in flooding frequency - the relevance of nutrient delivery through floodwater for the early stages of OM decomposition in tidal wetlands.

\subsection{Methods}

\section{Study sites and experimental design}

The worldwide survey was conducted during the 2015 growing season and included a total of 30 tidal-wetland sites. Sites were partly co-located within larger coastal and estuarine regions (Figure 4.1, Table 4.1). A total of 11 sites were situated along the European coasts of the North Sea, the Mediterranean, and the Baltic Sea; 13 sites were located along the east and west coasts of North America, including the St. Lawrence estuary, Bay of Fundy, Chesapeake Bay, and San Francisco Bay; and 4 mangrove sites were situated along the Caribbean coast of Central America in Belize and Panama. 
Additionally, one Chinese site (Yangtze Estuary) and one Argentinian site were included in our study. A total of 16 of the sites were salt marshes, 10 were tidal freshwater and brackish sites, and 4 sites were mangroves. In 21 sites, we compared high and low elevated zones, which were characterised by distinct plant-species compositions (i.e., different communities in high vs. mid vs. low marshes) or by different stature of mangroves (i.e., dwarf vs. fringe phenotypes). We used relative elevation (i.e., high vs. low elevated zone) as a site specific proxy for relative sea level. By doing so, we did not capture the actual variability in the tidal inundation regime across our study sites as these vary in absolute elevation and in elevation relative to mean high water. Finally, we included the long-term experimental site of the TIDE project in Massachusetts, USA, to assess effects of nutrient enrichment on litterdecomposition rate and stabilisation. Through nitrate additions to the incoming tides on at least 120 days per year, nutrient-enriched areas at the TIDE project site receive flood-water with 10-15-fold increased nitrogen $(\mathrm{N})$ concentrations compared to reference areas since 2004. From 2004 to 2010 also phosphate was added to the floodwater; however, this has been discontinued because creek water $\mathrm{P}$ concentrations are high enough to prevent secondary $\mathrm{P}$ limitation through $\mathrm{N}$ enrichment (details in Deegan et al., 2012; Johnson et al., 2016).

Decomposition rate and stabilisation were measured by deploying tea bags in 10 points per zone (or treatment) within a site $(n=10)$. Spacing between replicates within a zone (or treatment) was $\geq 2 \mathrm{~m}$. However, as sites differed considerably in their areal extent, the distribution and thus spacing between points had to be adjusted to be representative for the given system. Air temperature for the period of deployment was measured at the site, or temperature data was obtained from the online service of AccuWeather (http://accuweather.com, last access: 25 December 2016) for locations within a distance of $15 \mathrm{~km}$ to the site for most sites, but not further than $60 \mathrm{~km}$ for some remote sites. It needs to be noted here that top-soil temperature would differ from air temperature depending on factors such as canopy shading or tidal regime and water temperature. As a consequence, air temperature can only approximate the temperature conditions of the actual decomposition environment (Figure S4.2 in the Supplement). 
Table 4.1 Overview of study regions, site names, and site properties. Sites in which tea bags were deployed in zones of different elevation and flooding frequency are marked $(x)$. Different salinity classes are indicated as "S" (salt water), "B" (brackish water), and " $F$ " (fresh water). Tidal amplitude (Ampl.) is given in meters.

\begin{tabular}{|c|c|c|c|c|c|c|c|}
\hline Region & Site name & Zonation & Salinity & Ampl. & Ecosystem & Soilc & Contactsite ref. \\
\hline \multicolumn{8}{|l|}{ Europe } \\
\hline \multirow[t]{3}{*}{ Germany, Wadden Sea } & Dieksanderkoog, Elbe Est. & $\mathrm{x}$ & S & 3.0 & $\operatorname{marsh}$ & mineral & Mueller ${ }^{1}$ \\
\hline & Sönke-Nissen-Koog & $\mathrm{x}$ & S & 3.4 & marsh & mineral & Mueller ${ }^{1}$ \\
\hline & Spiekeroog & $\mathrm{x}$ & S & 2.0 & marsh & mineral & Dinter $^{2}$ \\
\hline \multirow[t]{3}{*}{$\begin{array}{l}\text { Netherlands, Wadden } \\
\text { Sea }\end{array}$} & Ameland & $\mathrm{x}$ & S & 2.3 & marsh & mineral & de Groot $^{3}$ \\
\hline & Noord-Friesland Buitendijks & $\mathrm{x}$ & $S$ & 2.3 & marsh & mineral & Esselink $^{4}$ \\
\hline & Schiermonnikoogb & - & S & 2.3 & marsh & mineral & Smit $^{5}$ \\
\hline Italy, Venice Lagoon & Venice Lagoon & $\mathrm{x}$ & S & 0.5 & marsh & mineral & D'Alpaos ${ }^{6}$ \\
\hline \multirow[t]{3}{*}{ Spain, Ebro Delta } & Vilacoto & - & $\mathrm{F}$ & $<0.1$ & marsh & organic & Ibáñez ${ }^{7}$ \\
\hline & Garxal & - & B & 0.2 & marsh & organic & Ibáñez ${ }^{7}$ \\
\hline & Alfacs & - & S & 0.2 & $\operatorname{marsh}$ & organic & Ibáñez ${ }^{7}$ \\
\hline Poland & Mechelińskie Łąkib & - & B & $<0.1$ & marsh & organic & Lazarus \\
\hline \multicolumn{8}{|l|}{ North America } \\
\hline \multirow{5}{*}{$\begin{array}{l}\text { Canada, St. Lawrence } \\
\text { Est., QC } \\
\text { Canada, Bay of Fundy, } \\
\text { NB } \\
\text { United States, Casco Bay, } \\
\text { ME }\end{array}$} & Rimouski & $\mathrm{x}$ & S & 3.2 & marsh & mineral & Neumeier 8 \\
\hline & Dipper Harbour & $\mathrm{x}$ & S & $>6.0$ & marsh & mineral & Chmura $^{9}$ \\
\hline & Long Marsh, north of inlet & - & S & 1.4 & marsh & organic & Johnson $^{10}$ \\
\hline & Long Marsh, south of inlet & - & B & 1.4 & marsh & organic & Johnson ${ }^{10}$ \\
\hline & $\begin{array}{l}\text { Long Marsh, south of } \\
\text { Narrows }\end{array}$ & - & $\mathrm{F}$ & 1.4 & marsh & organic & Johnson ${ }^{10}$ \\
\hline \multirow{2}{*}{$\begin{array}{l}\text { United States, Plum } \\
\text { Island Sound, MA }\end{array}$} & Laws Point & $\mathrm{x}$ & $\mathrm{S}$ & 2.9 & marsh & organic & Mozdzer ${ }^{11}$ \\
\hline & TIDE project ${ }^{\mathrm{a}}$ & $\mathrm{x}$ & $S$ & 2.9 & marsh & organic & Mozdzer $^{12}$ \\
\hline \multirow[t]{2}{*}{$\begin{array}{l}\text { United States, } \\
\text { Chesapeake Bay, MD }\end{array}$} & Patuxent River & $\mathrm{x}$ & $\mathrm{F}$ & 0.7 & marsh & organic & Baldwin $^{13}$ \\
\hline & Rhode River & $\mathrm{x}$ & B & 0.2 & marsh & organic & Schile-Beers ${ }^{14}$ \\
\hline \multirow{4}{*}{$\begin{array}{l}\text { United States, Eastern } \\
\text { Shore of VA } \\
\text { United States, San } \\
\text { Francisco Bay, CA }\end{array}$} & Wachapreague & $\mathrm{x}$ & $S$ & 0.6 & marsh & mineral & Schile-Beers \\
\hline & Coon Island & $\mathrm{x}$ & $\mathrm{S}$ & 0.7 & marsh & mineral & Schile-Beers ${ }^{15}$ \\
\hline & Rush Ranch & $\mathrm{x}$ & B & 0.7 & marsh & mineral & Schile-Beers ${ }^{15}$ \\
\hline & China Camp & - & S & 0.7 & marsh & mineral & Schile-Beers ${ }^{15}$ \\
\hline \multicolumn{8}{|l|}{ Central America } \\
\hline Belize, Caribbean coast & Twin Cays & $\mathrm{x}$ & S & 0.2 & mangrove & organic & Schile-Beers ${ }^{16}$ \\
\hline \multirow[t]{3}{*}{$\begin{array}{l}\text { Panama, Caribbean } \\
\text { coast, Bocas del Toro }\end{array}$} & Isla Solarte & $\mathrm{x}$ & $S$ & 0.3 & mangrove & organic & Schile-Beers ${ }^{17}$ \\
\hline & Isla Cristóbal, & $\mathrm{x}$ & S & 0.3 & mangrove & organic & Schile-Beers ${ }^{17}$ \\
\hline & Isla Popa & $\mathrm{x}$ & S & 0.3 & mangrove & organic & Schile-Beers ${ }^{17}$ \\
\hline \multicolumn{8}{|l|}{ South America } \\
\hline $\begin{array}{l}\text { Argentina, Mar Chiquita } \\
\text { Lagoon }\end{array}$ & Mar Chiquitab & $\mathrm{x}$ & B & 0.8 & marsh & mineral & Montemayor ${ }^{18}$ \\
\hline \multicolumn{8}{|l|}{ Asia } \\
\hline China, Yangtze Estuary & Dongtan & $\mathrm{x}$ & S & 2.5 & marsh & mineral & $\mathrm{Wu}^{19}$ \\
\hline \multicolumn{8}{|c|}{ 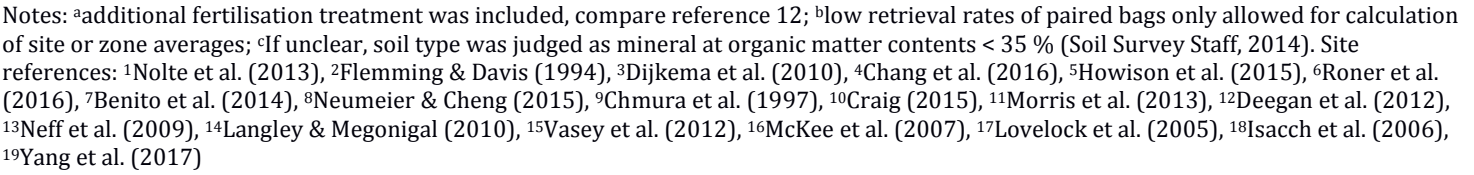 } \\
\hline
\end{tabular}




\section{Decomposition-rate and stabilisation measurements}

Decomposition rate $(k)$ and stabilisation $(S)$ were assessed following the TBI protocol (Keuskamp et al., 2013). The TBI approach can be considered as a simplified litterbag approach, allowing a time- and cost-efficient characterisation of the decomposition environment, because $k$ and $S$ can be estimated without repeated sampling of the decomposing material as in conventional approaches. This implies the assumptions that (1) $S$ is equal for the two types of material used in the approach and (2) that decomposition of non-hydrolysable materials during the 3 months of deployment is negligible. We refer the reader to Keuskamp et al. (2013) for further detail and validity assessments of assumptions.

At each measuring point, two nylon tea bags (200 $\mu \mathrm{m}$ mesh size), one containing green tea (EAN: 8722700 055525; Lipton, Unilever, UK) and one containing rooibos (8 722700 188438, Lipton, Unilever, UK), were deployed as pairs in $\sim 8 \mathrm{~cm}$ soil depth, separated by $\sim 5 \mathrm{~cm}$. The initial weight of the contents was determined by subtracting the mean weight of 10 empty bags (bag + string + label) from the weight of the intact tea bag prior to deployment (content + bag + string + label). The tea bags were retrieved after an incubation time of $92 \pm 6$ (SD) days, with three sites having an incubation period $>100$ days and one site $<80$ days. Upon retrieval, tea bags were opened, and tea materials were carefully separated from fine roots and soil, dried for $48 \mathrm{~h}$ at $70^{\circ} \mathrm{C}$, and weighed.

Calculations for $k$ and $S$ followed Keuskamp et al. (2013):

$$
\begin{aligned}
& W_{e}(t)=a_{r} e^{-k t}+\left(1-a_{r}\right) \\
& S=1-a_{g} / H_{g} \\
& a_{r}=H_{r}(1-S)
\end{aligned}
$$

$W_{r}(t)$ describes the substrate weight of rooibos after incubation time ( $t$ in days), $a_{r}$ is the labile and $1-a_{r}$ is the recalcitrant fraction of the substrate, and $k$ is the decomposition rate constant. $S$ describes the stabilisation factor, $a_{g}$ the decomposable fraction of green tea (based on the mass loss during incubation), and $H_{g}$ the hydrolysable fraction of green tea. The decomposable fraction of rooibos tea is 
calculated in equation (4.3) based on its hydrolysable fraction $\left(H_{r}\right)$ and the stabilisation factor $S$. With $W r(t)$ and $a_{r}$ known, $k$ is calculated using equation (4.1). In accordance with Keuskamp et al. (2013), extractions for determination of the hydrolysable fractions of green and rooibos tea followed Ryan et al. (1990). However, instead of using Ryan's "forest products protocol" we conducted the alternative "forage fiber protocol" for the determination of the hydrolysable fraction. Briefly, $1 \mathrm{~g}$ of dried tea material $\left(70^{\circ} \mathrm{C}\right.$ for $\left.24 \mathrm{~h}\right)$ was boiled in cetyltrimethylammonium bromide (CTAB) solution (1 g CTAB in $100 \mathrm{~mL} 0.5 \mathrm{M} \mathrm{H}_{2} \mathrm{SO}_{4}$ ) for $1 \mathrm{~h}$ (Brinkmann et al., 2002; Ryan et al., 1990). The extract was filtered through a 16-40 $\mu \mathrm{m}$ sinter filter crucible (Duran, Wertheim, Germany) using a water-jet vacuum pump and washed with 150 $\mathrm{mL}$ of hot water followed by addition of acetone until no further de-colouration occurred (Brinkmann et al., 2002). The remaining material was left in the sinter, dried for $12 \mathrm{~h}$ at $70^{\circ} \mathrm{C}$, cooled in a desiccator, and weighed. $20 \mathrm{~mL}$ of $72 \% \mathrm{H} 2 \mathrm{SO} 4$ was added to the sinter and filtered off after an incubation of $3 \mathrm{~h}$, followed by washing with hot water to remove remaining acid. The sinter was dried at $70^{\circ} \mathrm{C}$ for $12 \mathrm{~h}$, cooled in a desiccator, and weighed to determine the non-hydrolysable fraction. Finally, the sinter containing the remaining sample was ignited at $450^{\circ} \mathrm{C}$ for $3 \mathrm{~h}$ in order to determine the ash content of the material.

In addition to the determination of the hydrolysable fraction, we measured total $\mathrm{C}$ and $\mathrm{N}$ contents of the tea material using an elemental analyser (EURO-EA 3000, Euro Vector, Pavia, Italy). The hydrolysable fraction of both green and rooibos tea was higher than reported in Keuskamp et al. (2013) (Table S4.1 in the Supplement). However, the determined $\mathrm{C}$ and $\mathrm{N}$ contents of the tea materials are in agreement with those reported in Keuskamp et al. (2013) (Table S4.1). Therefore, deviations from the hydrolysable fraction as reported previously are likely due to the less conservative extraction assessment in the present study and not due to actual changes in the quality of the materials.

\section{Data mining}

Relationships between single parameters and litter decomposition are often not linear. Instead, critical thresholds seem to exist at which a certain predictor (e.g. mean annual temperature) becomes influential (Prescott, 2010; Rothwell et al., 2008). In the first step of data mining, we therefore used classification and regression 
tree analysis (CART) to identify potential thresholds and important predictors for $k$ and $S$ (Figure S4.1 in the Supplement). Data mining was conducted using STATISTICA 10 (StatSoft Inc., Tulsa, OK, USA).

\section{Statistical analyses}

To test for effects of temperature on $k$ and $S$, Spearman rank correlations were conducted using site means $(n=30)$. As we did not expect temperature to be independent of other parameters in this observational study, we constructed a Spearman correlation matrix including the parameters temperature, latitude, tidal amplitude, salinity class, $k$, and $S$. Additionally, we tested for differences in these parameters between marshes and mangroves and sites with mineral and organic soils, using Mann-Whitney U tests (Table 4.2). Curve fitting was used to further explore relationships between temperature, $k$, and $S$, and regression models with the lowest standard error of estimate and highest $\mathrm{R}^{2}$ are displayed in Figures 4.2 and 4.3.

To test for effects of relative elevation (as proxy for relative sea level) on $k$ and $S$, two-tailed paired $t$ tests were conducted. Mean values of high and low elevated zones of the 21 sites where tea bags were deployed in both high and low elevation zones were used $(n=21)$. The absence of outliers and normal distribution of the difference in the independent variable (as assessed visually) assured robustness of paired $t$ tests. To assess the consistency of potential effects of relative elevation on $k$ and $S$, one-way ANOVAs were used in each site separately (replication was sufficient in 20 sites). Normal distribution of residuals was assessed visually, Levene's test was used to test for homogeneity of variance, and data were log-transformed if assumptions were not met. Mann-Whitney $U$ tests were conducted as a nonparametric alternative when log-transformed data did not meet ANOVA assumptions (Table S4.2).

We tested for effects of nutrient enrichment on $k$ and $S$ in the data from the TIDE project site (Massachusetts, USA) using two-way ANOVA with enrichment treatment and marsh zone as predictors. When Levene's test indicated heterogeneous variance (true for $k$ ), data were log-transformed, which stabilised variance. Normal distribution of residuals was assessed visually. 
Lastly, in order to assess the applicability of the TBI approach in tidal wetlands, we separately investigated the temperature response of $k$ and $S$ for the 10 sites situated along the North American Atlantic coast (Figure 4.3). Previous studies have shown clear temperature (or latitudinal) effects on decomposition and microbial activity along this well-studied transect (Kirwan et al., 2014; Mozdzer et al., 2014), allowing us to compare the TBI approach with other methods. Regional scale transects with sufficient temperature range along other coastlines could not be identified (Figure 4.1; Table 4.1). Statistical analyses were conducted using STATISTICA 10 (StatSoft Inc., Tulsa, OK, USA).
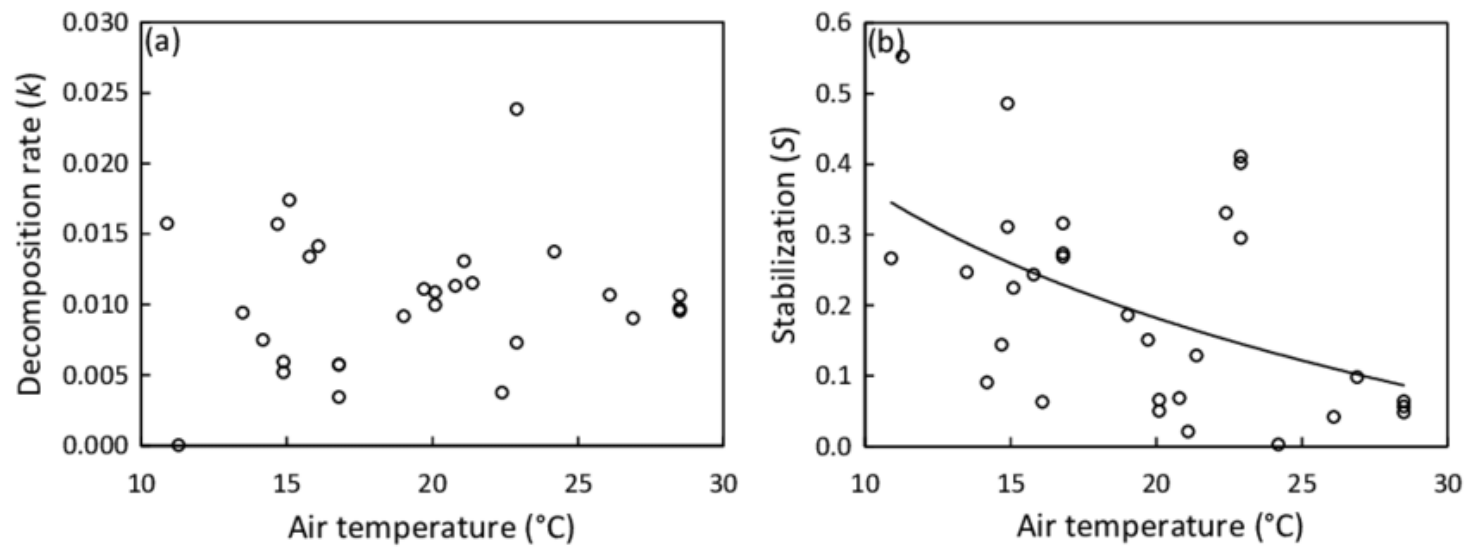

Figure 4.2 Site means of decomposition rate (a) and stabilisation (b) versus mean air temperature during deployment period. Regression line illustrates the significant relationship between temperature and stabilisation (Table 4.2); the regression model with the lowest standard error of estimate (SEE) and highest $\mathrm{R}^{2}$ is shown: $y=-0.27 \ln (x)+0.99 ; R^{2}=0.239 ; \mathrm{SEE}=0.131$. Excluding Mediterranean sites $\left(21.9-23.6^{\circ} \mathrm{C} ; \mathrm{n}=4\right)$ from the regression yields the following: $\mathrm{y}=-0.344 \ln (\mathrm{x})+1.233 ; \mathrm{R}^{2}=0.510 ; \mathrm{SEE}=0.101$.

\subsection{Results}

\section{Temperature effects}

We found no relationship between temperature and $k$ across study sites (Figure 4.2a; Table 4.2). Also, CART revealed temperature only as a subordinate splitting variable for $k$. Specifically, temperature seems to positively affect $k$ in mesotidal systems only (amplitude $>2.1 \mathrm{~m}$ ) with sites $\geq 14.5^{\circ} \mathrm{C}$ during deployment supporting higher rates of decomposition than sites characterised by lower temperatures. However, this apparent temperature effect was inconsistent within the group of observations with tidal amplitude $>2.1 \mathrm{~m}$ (Figure S4.1a). In contrast to the results of the global-scale 


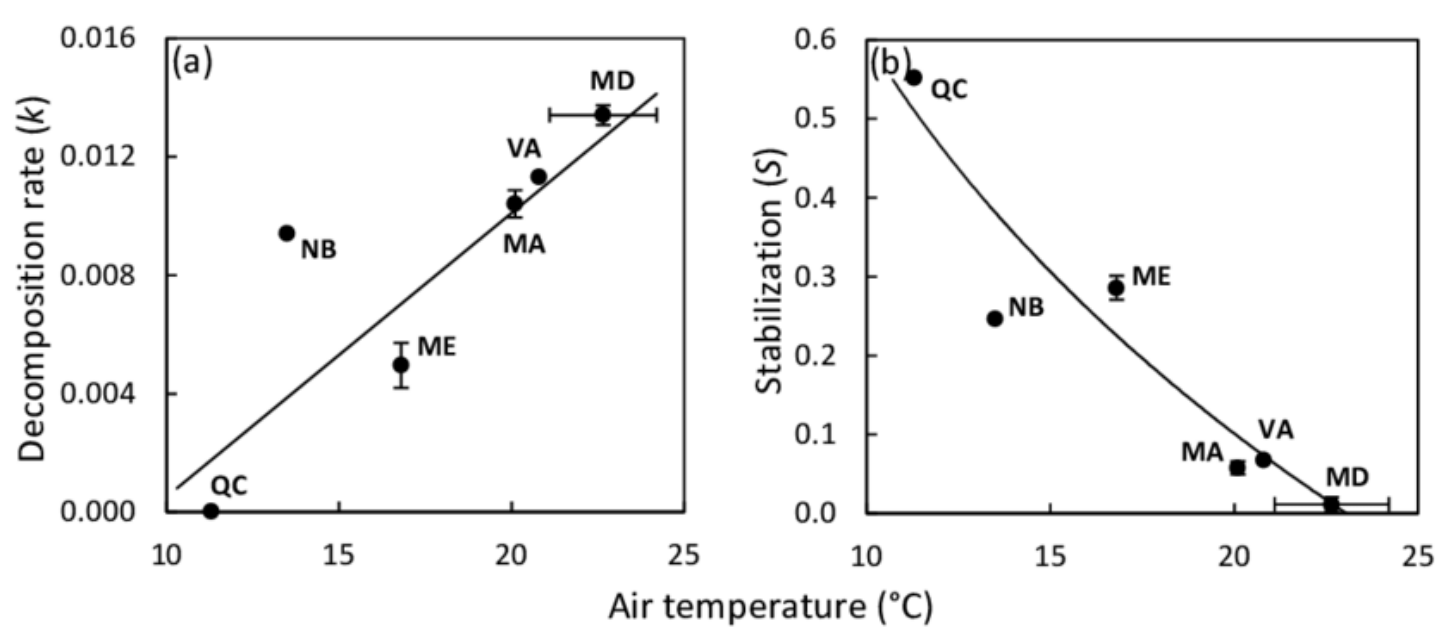

Figure 4.3 Site means of decomposition rate (a) and stabilisation (b) versus mean air temperature of the deployment period shown for the 10 sites situated along the latitudinal gradient of the North American Atlantic coast; state abbreviations are shown (compare Table 4.1). Regression lines illustrate significant relationships; regression models with the lowest standard error of estimate (SEE) and highest R2 are shown. Decomposition rate: $\mathrm{y}=0.001 \mathrm{x}-0.0091 ; \mathrm{R} 2=0.692 ; \mathrm{SEE}=0.003$. Stabilisation: $\mathrm{y}=-0.712 \ln (\mathrm{x})+2.2331 ; \mathrm{R} 2=0.860 ; \mathrm{SEE}=$ 0.070 .

assessment, $k$ was strongly and positively related with temperature across the 10 sites situated along the North American Atlantic coast, with temperature explaining approx. $70 \%$ of variability in $k$ (Figure $4.3 \mathrm{a}$ ).

Stabilisation was strongly affected by temperature (Figure $4.2 \mathrm{~b}$; Table 4.2 ). The significant negative correlation between $S$ and temperature agrees well with the CART. However, CART also identified a narrow temperature range $\left(21.9-23.6^{\circ} \mathrm{C}\right)$ in which increasing temperature led to higher stabilisation (Figure S4.1b; node 11). This group of observations diverging from the general pattern is also clearly visible in Figure $4.2 \mathrm{~b}$ and represents the four Mediterranean sites (Ebro Delta and Venice Lagoon) of our survey. The positive relationship between temperature and $S$ was even clearer when focusing on the 10 sites along the North American Atlantic coast, with temperature explaining $>85 \%$ of variability in $S$ (Figure $4.3 \mathrm{~b}$ ).

Temperature was highly correlated with latitude and tidal amplitude, and temperature was not independent of soil type (mineral or organic) and ecosystem type (marsh or mangrove) (Table 4.2). The effect of latitude was similarly pronounced as the temperature effect on $S$ - and consequently- effects of these two parameters on $S$ cannot be separated (Table 4.2). By contrast, tidal amplitude and soil type did not significantly affect $\mathrm{S}$, and the difference in $S$ between mangroves and marshes was only marginally significant (Table 4.2). These findings suggest that the 
presented temperature effect on $S$ occurs to be mainly independent of tidal amplitude and soil type.

\section{Effects of relative sea level and nutrient enrichment}

Paired comparisons of high vs. low elevated zones indicate no consistent effect of relative sea level on $k$ across sites ( $\mathrm{p}>0.1$; Figure 4.4a), whereas $S$ was significantly reduced by $29 \%$ in low compared to high elevated zones ( $<<0.01$; Figure $4.4 \mathrm{~b}$ ). Testing for effects of relative sea level within each site separately revealed that $S$ is significantly reduced by $28-87 \%$ in the lower elevated zone in 14 of 20 sites, whereas a significant increase of $S$ in low vs. high elevated zones was found in none of the 20 sites (Table S4.2). This finding demonstrates the consistency of the sea-level effect on $S$ irrespective of ecosystem type (marsh or mangrove), soil type (mineral or organic), and site salinity (brackish or salt water). In nine of the sites, we also found a significant effect of relative sea level on $k$. However, in six sites $k$ was significantly higher in low vs. high zones, and in three sites $k$ was significantly lower in low vs. high zones. The direction of effects on $k$ seems to be independent of ecosystem type, soil type, and site salinity (Table S4.2).

Table 4.2 Spearman rank coefficients between the variables temperature, latitude, tidal amplitude, salinity class, $k$, and $S$ (coefficients are bold typed at $\mathrm{p} \leq 0.05)$ and comparisons of temperature $\left({ }^{\circ} \mathrm{C}\right)$, latitude $\left({ }^{\circ}\right)$, amplitude $(\mathrm{m})$, $k$, and $S$ between ecosystem types (mangrove vs. marsh) and soil types (mineral vs. organic) shown as site means $\pm \mathrm{SE}, \mathrm{n}=30$. Asterisks show results of Mann-Whitney U tests and denotesignificant differences as follows: $\mathrm{p} \leq 0.1=$., $\mathrm{p} \leq 0.05={ }^{*}, \mathrm{p} \leq 0.01={ }^{* *}$, not significant $=$ ns.

\begin{tabular}{|c|c|c|c|c|c|c|}
\hline & Temperature & Latitude & Amplitude & Salinity & $S$ & $k$ \\
\hline \multicolumn{7}{|c|}{$\begin{array}{l}\text { Spearman rank } \\
\text { correlations }\end{array}$} \\
\hline Temperature & & -0.78 & -0.68 & -0.09 & -0.44 & 0.02 \\
\hline Latitude & -0.78 & & 0.49 & 0.05 & 0.43 & 0.06 \\
\hline Amplitude & -0.68 & 0.49 & & 0.40 & 0.01 & 0.00 \\
\hline Salinity & -0.09 & 0.05 & 0.40 & & -0.13 & -0.08 \\
\hline$S$ & -0.44 & 0.43 & 0.01 & -0.13 & & -0.51 \\
\hline$k$ & 0.02 & 0.06 & 0.00 & -0.08 & -0.51 & \\
\hline \multicolumn{7}{|c|}{ Group means $\pm S E$} \\
\hline Soil type & $* *$ & ns & $* *$ & & ns & ns \\
\hline Mineral & $17.0 \pm 1.1$ & $45.5 \pm 2.1$ & $2.3 \pm 0.6$ & & $0.22 \pm 0.04$ & $0.010 \pm 0.001$ \\
\hline Organic & $22.2 \pm 1.2$ & $34.5 \pm 3.9$ & $0.8 \pm 0.3$ & & $0.17 \pm 0.04$ & $0.010 \pm 0.001$ \\
\hline Ecosystem & $* *$ & ** & $*$ & & . & ns \\
\hline Marsh & $18.3 \pm 0.8$ & $44.4 \pm 1.3$ & $1.7 \pm 0.4$ & & $0.22 \pm 0.03$ & $0.010 \pm 0.001$ \\
\hline Mangrove & $28.1 \pm 0.4$ & $11.4 \pm 2.0$ & $0.3 \pm 0.0$ & & $0.07 \pm 0.01$ & $0.010 \pm 0.000$ \\
\hline
\end{tabular}


The nutrient enrichment treatment at the TIDE project site decreased $S$ by $72 \%$ in the high marsh (Figure 4.4d). $S$ in the low marsh was similarly low as in the enriched high marsh and not further reduced by nutrient enrichment (Figure 4.4d). In contrast, $k$ was not responsive to the nutrient enrichment treatment in either low or high marsh (Figure 4.4c).

\section{Other factors influencing decomposition rate and stabilisation}

CART revealed tidal amplitude as an important predictor for $k$. However, this result needs to be considered cautiously because splits based on tidal amplitude suggest mixed effects (Figure S4.1a). Accordingly, no significant relationship existed between tidal amplitude and $k$ across sites (Table 4.2). Soil type (mineral or organic) and ecosystem type (marsh or mangrove) did not affect $k$ and $S$ across sites (Table 4.2). We found no significant relationship between salinity class and $k$ or $S$ (Table 4.2). Also, CART did not reveal salinity class as an important factor for $k$ and $S$.
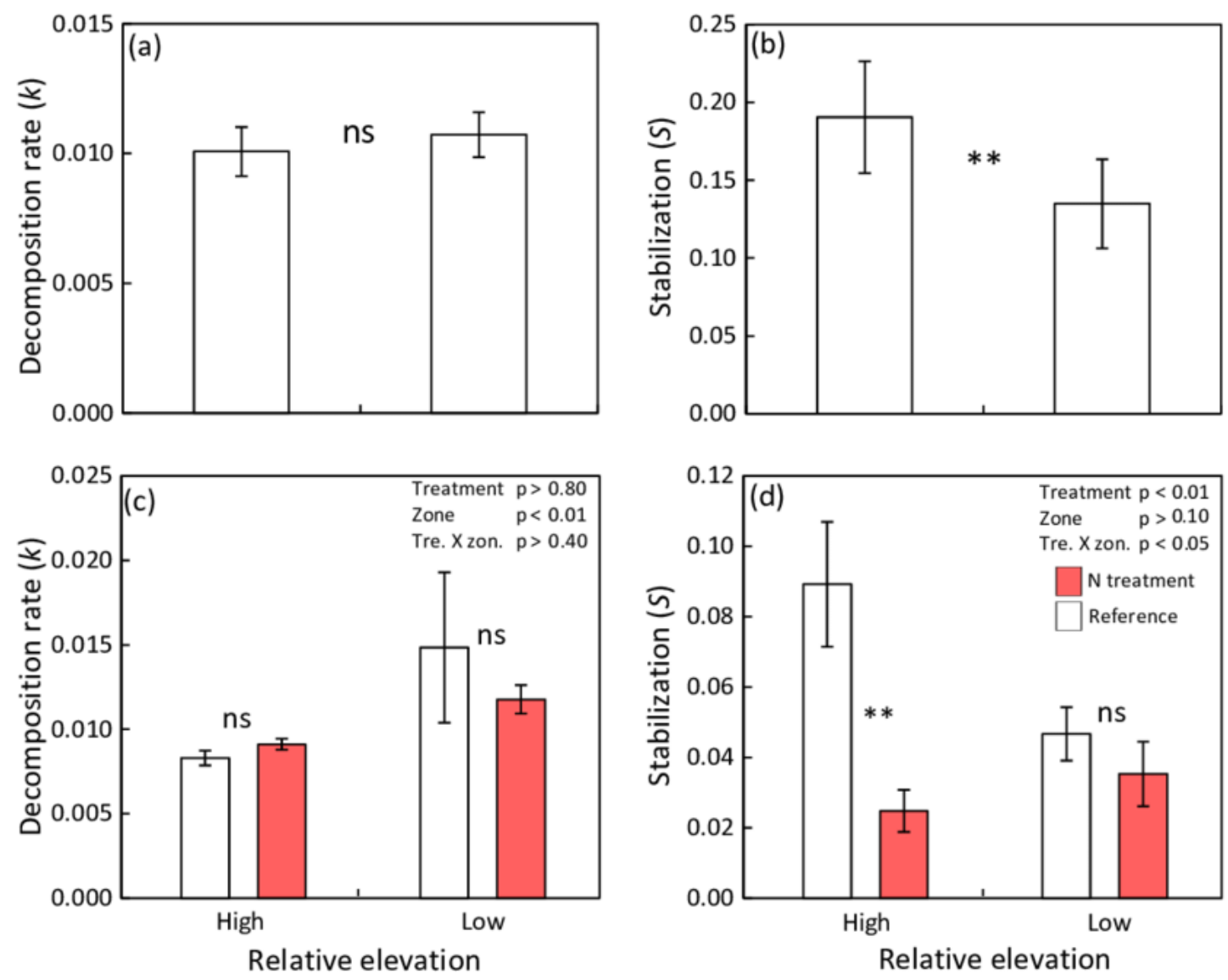

Figure 4.4 (a) Decomposition rate and (b) stabilisation in high and low elevated zones of tidal marsh and mangrove sites ( $\mathrm{n}=21$; compare Tables 4.1, S4.2). (c) Decomposition rate and (d) stabilisation in nutrientenriched versus reference high marsh (Spartina patens zone) and low marsh (Spartina alterniflora zone) of the TIDE project site at the Plum Island Sound estuary, Massachusetts, USA. Shown are means \pm SE and results of paired $t$ tests $(\mathrm{a}, \mathrm{b})$ and two-way ANOVAs plus Tukey's HSD (honest significant difference) test for pairwise comparisons $(\mathrm{c}, \mathrm{d}): \mathrm{ns}=$ not significant; ${ }^{*}=\mathrm{p} \leq 0.05 ;{ }^{* *}=\mathrm{p} \leq 0.01$ 


\subsection{Discussion}

\section{Temperature effects on decomposition processes}

A positive relationship between temperature and decomposition rate was found only at the regional scale across the 10 sites along the North American Atlantic coast (Figure 4.3a), but not across all sites at the global scale (Figure 4.2a). Even though this finding seems surprising in the context of basic biokinetic theory, it is in agreement with findings of Djukic et al. (2018), demonstrating climate effects on the breakdown of the TBI materials across terrestrial ecosystems at the biome scale, but not at the global scale across biomes.

The present study used air temperature as a proxy for topsoil temperature. Thus, the temperature regime of the decomposition environment was only approximated, which certainly would have weakened a significant relationship between temperature and $k$. However, following typical $\mathrm{Q}_{10}$ values for biological systems of 2-3 (Davidson \& Janssens, 2006), $k$ should have at least doubled over the gradient of $\Delta \mathrm{T}>15^{\circ} \mathrm{C}$; yet our data do not even show a tendency of an effect $\left(\mathrm{r}_{\mathrm{s}}=0.02\right.$; Table 4.2). We therefore propose that other parameters exerted overriding influence on $\mathrm{k}$, mainly masking temperature effects, and have not been captured by our study design. This notion is in line with the fact that studies conducted at single-marsh to regional scales report equivocal results on the temperature response of $k$, ranging from no or moderate (Charles \& Dukes, 2009; Janousek et al., 2017; Kirwan et al., 2014 ) to strong seasonally driven temperature effects with a $Q_{10}>3.4$ as found within a single site (Kirwan \& Blum, 2011). For instance, large differences in site elevation and hydrology could have induced high variability in $k$ across sites and masked potential temperature effects. Indeed, we demonstrate significant but mixed effects of relative sea level on $k$ for some sites (Table S4.2); however, we do not have sufficient data on actual site elevation or hydrology to control for these factors as covariates affecting the temperature effect on $k$. Likewise, we do not have data on nutrient availability, plant productivity, or various anthropogenic impacts that could have exerted strong control over decomposition processes in the studied sites (Deegan et al., 2012; Keuskamp et al., 2015b; Macreadie et al., 2017; Mueller et al., 2016). 
In contrast to the missing effect of temperature on $k$, OM stabilisation was strongly affected. Overall, $S$ decreased by $75 \%$ over our temperature gradient from 10.9 to $28.5^{\circ} \mathrm{C}$ (Figure $4.2 \mathrm{~b}$ ). Thus, we demonstrate a considerable temperature effect on the initial steps of biomass decomposition in tidal wetlands. However, as also demonstrated for $k$, the temperature effect on $S$ was much clearer at the regional scale when focusing on the sites along the North American Atlantic coast (Figure 4.3b), suggesting high variability in $S$ across regions irrespective of the temperature regime. In accordance, we also demonstrate a clear divergence of the four Mediterranean sites from the regression model (Figure 4.2b), which could be related to differences in precipitation or nutrient availability across study regions. Future experimental work is therefore required in order to further assess the effects of temperature on $\mathrm{OM}$ stabilisation and to separate temperature from latitudinal and other interacting effects (e.g. as outlined above for $k$ ) that are difficult to control for in observational studies.

The temperature effect on the initial steps of biomass decomposition we identified in the present study is not driven by changes in decomposition rate per se, but by changes in the transformation of fresh and rapidly decomposable organic matter into stable compounds. This could have important implications for carbon sequestration (e.g., Cotrufo et al., 2013). In their global-scale assessment, Chmura et al. (2003) indeed report a negative relationship of soil organic C density and mean annual temperature within both salt marshes and mangroves. Chmura and colleagues hypothesised stimulated microbial decomposition at higher temperatures to be the responsible driver of this relationship. Plant production and thus OM input is known to increase with latitude and temperature in tidal wetlands (Baldwin et al., 2014; Charles \& Dukes, 2009; Gedan \& Bertness, 2009; Kirwan et al., 2009), but this increase seems to be more than compensated for by higher microbial decomposition. Working at the same spatial scale as Chmura et al. (2003), our study supports this hypothesis and provides mechanistic insight into the temperature control of $\mathrm{OM}$ decomposition as a potential driver of carbon sequestration in tidal wetlands.

\section{Relative-sea-level effects on decomposition processes}

Flooding and thus progressively lower oxygen availability in soil is supposed to be a strong suppressor of decomposition (Davidson \& Janssens, 2006). In tidal wetlands, 
differences in flooding frequency along elevational gradients often induce sharp gradients in oxygen availability and redox conditions (Davy et al., 2011; Kirwan et al., 2013; Langley et al., 2013), with potentially strong influence on OM decomposition and carbon cycling. However, the effect of redox conditions on OM breakdown is determined by the chemical quality of the decomposing material: Decomposition of aged or recalcitrant $\mathrm{OM}$ can indeed be slower and incomplete in the absence of oxygen, whereas the breakdown of fresh and labile OM can be largely unaffected by oxygen availability (Benner et al., 1984; Kristensen et al., 1995). Thus, also decomposition rate and stabilisation of labile, hydrolysable $\mathrm{OM}$, as assessed in the present study, is not necessarily affected by redox conditions. Here, we demonstrate that $k$ is not reduced in low (more frequently flooded) vs. high elevated (less frequently flooded) zones of tidal wetlands (Figure 4.4a). This finding is in accordance with an increasing number of studies demonstrating negligible direct effects of sea level on decomposition rate in tidal-wetland soils (Janousek et al., 2017; Kirwan et al., 2013; Mueller et al., 2016). Furthermore, we show that $S$ is strongly reduced in low vs. high elevation zones, suggesting that the conversion of recent $\mathrm{OM}$ inputs to stable compounds is in fact lower in more flooded zones of tidal wetlands. As the stabilisation of labile OM inputs is a major driver of SOM formation (Cotrufo et al., 2013, 2015; Haddix et al., 2016), one important implication of this finding is that accelerated SLR yields the potential to decrease the carbon-sequestration potential of tidal wetlands.

The mechanism by which $S$ is decreased in the more flooded zones of the present study is unknown. Because we did not observe consistent salinity effects on $S$ and $k$ in our data, we do not suppose that regular exposure of litter to salt water explains the unexpected finding. Likewise, soil temperature was not consistently affected by relative elevation across sites $(\mathrm{p}>0.3$; paired $t$ test based on data shown in Figure S4.2). Instead, we argue that more favourable soil moisture conditions in low vs. high elevated zones could have decreased OM stabilisation if higher flooding frequencies did not induce redox conditions low enough to suppress microbial activity in the top soil. In support of this, flooding frequency-induced changes in moisture conditions have been reported as the primary driver of surface litter breakdown, leading to more than 4-fold increased litter mass loss in low vs. highmarsh zones of a New Jersey salt marsh (Halupa \& Howes, 1995). Additionally, 
greater nutrient availability and less nutrient-limited microbial communities in more frequently flooded zones could have contributed to this effect (Deegan et al., 2012; Kirwan et al., 2013). Strong effects of both high-quality marine-derived OM and nutrient amendments on microbial structure and activity have been reported (Deegan et al., 2012; Kearns et al., 2016; Keuskamp et al., 2015a; Mueller et al., 2017), suggesting that regular marine $\mathrm{OM}$ and nutrient inputs in more frequently flooded zones can positively affect decomposition (see further discussed below in the next section).

\section{Nutrient enrichment reduces stabilisation -insights from the TIDE project}

In addition to our global survey of early-stage decomposition processes in tidal wetlands, we included the long-term ecological research site of the TIDE project in Massachusetts, USA, to experimentally assess both the effects of coastal eutrophication and the relevance of nutrient delivery through floodwater for $\mathrm{OM}$ decomposition in tidal wetlands. Important for our argument that decomposition may be favoured by higher nutrient availability in low elevated, more frequently flooded zones, we observed a strong reduction ( $>70 \%$ ) of $S$ by nutrient enrichment in the high marsh. Additionally, $S$ in the low marsh was low as in the fertilised high marsh and not further reduced by fertilisation (Figure 4.4d). Johnson et al. (2016) demonstrate that nutrient-enriched high-marsh plots of the TIDE project receive $19 \pm 2 \mathrm{gNm}^{-2} \mathrm{yr}^{1}$, approximately 10 times the $\mathrm{N}$ load of reference high-marsh plots $(2$ $\pm 1 \mathrm{gNm}^{-2} \mathrm{yr}^{-1}$; mean $\pm \mathrm{SE}$ ), thus explaining the strong treatment effect observed in the high marsh. In accordance with low stabilisation in the reference low marsh, which is as equally low as the nutrient-enriched high marsh, reference plots of the low marsh receive $16 \pm 4 \mathrm{gNm}^{-2} \mathrm{yr}^{1}$, the same high $\mathrm{N}$ load as the enriched high-marsh plots. Surprisingly, however, N loads of $171 \pm 19 \mathrm{gNm}^{-2} \mathrm{yr}^{1}$ in the enriched low marsh plots do not result in additional reduction of $S$ compared to the reference low marsh (Figure 4.4d). These findings suggest that microbial communities of the high marsh are $\mathrm{N}$ limited and that $\mathrm{N}$ additions to a certain level can stimulate early $\mathrm{OM}$ decomposition and thus reduce stabilisation. The missing effect of $\mathrm{N}$ loads exceeding $16 \mathrm{gm}^{-2} \mathrm{yr}^{1}$ on stabilisation in the low marsh indicates that microbial communities are less $\mathrm{N}$ limited due to the naturally greater nutrient availability. The findings of the TIDE project therefore support our concept that higher nutrient availability and less 
nutrient-limited microbial communities in more frequently flooded zones could have contributed to the observed reduction of OM stabilisation in low vs. high elevated zones of tidal wetlands in our global assessment.

Although our conclusions on effects of nutrient enrichment on $\mathrm{OM}$ decomposition are based on the findings of a single field experiment only, our study adds to a growing number of reports illustrating the impact of coastal eutrophication on tidal-wetland C cycling (Deegan et al., 2012; Keuskamp et al., 2015b; Kirwan \& Megonigal, 2013; Morris \& Bradley, 1999). At the same time, however, we highlight the need to improve our understanding of coastal eutrophication in interaction with other global changes, particularly accelerated SLR and concomitant changes in flooding frequency, on the cycling of both labile and refractory $\mathrm{C}$ pools in order to predict future stability of tidal wetlands.

\section{The Tea Bag Index - methodological considerations}

Interpretation of results obtained from standardised approaches like the present needs to be made cautiously because OM quality (i.e., its chemical composition) is a key parameter affecting its decomposition. As the quality of the TBI materials differ from that of wetland plant litters, and likely even more from the quality of the imported allochthonous OM (Khan et al., 2015), we did not expect to capture actual rates of early-stage $\mathrm{OM}$ breakdown in this study. Instead, we used the TBI to characterise the decomposition environment by obtaining a measure for the potential to decompose and stabilise the deployed standardised material. Standardised approaches like this, or also the cotton-strip assay (e.g., Latter \& Walton, 1988), are useful to separate the effects of environmental factors other than $\mathrm{OM}$ quality on decomposition processes and to assess their relative importance. Otherwise, complex interaction effects of the abiotic environment and OM quality make it difficult to predict the relevance of certain environmental factors for decomposition processes, potentially masking the effects of important global-change drivers (Prescott, 2010). At the same time, however, the global-change factors considered in the present study are likely to induce changes in the quality of the $\mathrm{OM}$ accumulating in tidal wetlands, for instance through shifts in plant-species composition and plant-tissue quality, that can potentially counterbalance or amplify the effects on decomposition processes suggested here. Future research therefore 
needs to address OM quality feedbacks on decomposition processes in tidal wetlands in order to gain a more complete understanding of global-change effects on tidalwetland stability and carbon-sequestration capacity.

Based on the $S$ values obtained from initial calculations using the hydrolysable fractions suggested by Keuskamp et al. (2013), a large number of observations yielded a negative $S$ (Table S4.3). S becomes negative when the mass loss from green tea is greater than the predicated maximum loss based on its hydrolysable fraction. At least two processes could have caused this result: first, our data indicate that redox conditions in the top soil of tidal wetlands are not low enough to hamper decomposition of the hydrolysable fraction of the TBI materials. As a consequence, high top-soil moisture of tidal wetlands could provide favourable conditions for decomposition, following typical moisture-decomposition relationships as demonstrated for terrestrial ecosystems (e.g. Curiel Yuste et al., 2007). Potentially, moisture conditions and nutrient supply even allow for considerable breakdown of non-hydrolysable compounds within three months of deployment, such as lignin (Berg \& McClaugherty, 2014; Duboc et al., 2014; Feng et al., 2010; Knorr et al., 2005). Second, different protocols to determine the hydrolysable fraction of plant materials exist and lead to variable results. The hydrolysable fraction can consequently be over- or underestimated depending on protocol and type of sample material. The use of the slightly higher hydrolysable fractions we determined for calculations of the TBI parameters effectively eliminated negative $S$ values. In that regard, using the values obtained from the alternative protocol given in Ryan et al. (1990) seemed more reasonable in our study. However, it needs to be stressed here that direction and size of reported effects on $S$ and $k$ in the present study are almost independent of the hydrolysable fraction used for calculations.

Future research will have to test the applicability of the TBI approach in different ecosystems and test the validity of its assumptions (i.e., $S$ is equal for both types of material used, and mass loss of non-hydrolysable material is negligible over 3 months of deployment). The results of our regional-scale assessment along the North American Atlantic coast transect are in tight agreement with previously reported results on cellulose breakdown and soil microbial activity along this wellstudied transect (Kirwan et al., 2014; Mozdzer et al., 2014). We can thereby 
demonstrate the usefulness of the TBI approach to assess early-stage decomposition in tidal-wetland soils.

\section{Implications}

This study addresses the influence of temperature, relative sea level, and coastal eutrophication on the initial transformation of biomass to SOM, and it does not encompass their effects on the existing SOM pool. However, aspects of $S$ and $k$ are key components of many tidal-wetland resiliency models (Schile et al., 2014; Swanson et al., 2014) that have highlighted the critical role of the organic contribution to marsh elevation gain. Although actual rates of $S$ and $k$ cannot be inferred from this study using a standardised approach, our data identify strong negative effects of temperature, relative sea level, and coastal eutrophication on the stabilisation of fresh organic inputs to tidal-wetland soils. We argue that these unanticipated combined effects yield the potential to strongly accelerate carbon turnover in tidal wetlands, thus increasing their vulnerability to accelerated SLR, and we highlight the need for experimental studies assessing the extent to which the here identified effects translate into native OM dynamics.

Data availability. The data used in this work are available at the PANGEA digital data library (Mueller et al., 2018).

The Supplement related to this article is available online at https://doi.org/10.5194/bg-15-3189-2018-supplement.

\section{Acknowledgements}

We thank Svenja Reents, Melike Yildiz, Anja Schrader, Detlef Böhm, Cailene Gunn, Marcella Roner, Johan Krol, Marin van Regteren, Jacek Mazur, Ana Genua, Lluís Jornet, David Mateu, Sarah King, Shayne Levoy, and Lyntana Brougham for help with field and lab work. We thank Joost Keuskamp, Judith Sarneel, Catherine Lovelock, and two anonymous reviewers for their valuable comments on our manuscript. The project was partly funded by the Bauer-Hollmann Stiftung and the Rudolf und Helene Glaser Stiftung in the framework of the INTERFACE project. We acknowledge the financial support provided by the International Affairs, Strategy and Partnership office of Universität Hamburg. Support for Thomas J. Mozdzer came from NSF DEB-1354124 
and DEB-1719621. This is contribution 25 from the Smithsonian's MarineGEO Network.

\section{References}

Baldwin, A. H., Jensen, K., \& Schönfeldt, M. (2014). Warming increases plant biomass and reduces diversity across continents, latitudes, and species migration scenarios in experimental wetland communities. Global Change Biology, 20, 835-850.

Barbier, E. B., Hacker, S. D., Kennedy, C., Koch, E., Stier, A. C., \& Silliman, B. R. (2011). The value of estuarine and coastal ecosystem services. Ecology Monographs, 81, 169-193.

Benito, X., Trobajo, R., \& Ibáñez, C. (2014). Modelling habitat distribution of Mediterranean coastal wetlands: The Ebro delta as case study. Wetlands, 34, 775-785.

Benner, R., Maccubbin, A. E., \& Hodson, R. E. (1984). Anaerobic biodegradation of the lignin and polysaccharide components of lignocellulose and synthetic lignin by sediment microflora. Applied and Environmental Microbiology, 47, 9981004.

Berg, B., \& McClaugherty, C. (2014). Plant litter: Decomposition, humusformation, carbon sequestration. 3rd edition, Springer-Verlag, Berlin/Heidelberg.

Berg, B., Berg, M. P., Bottner, P., Box, E., Breymeyer, A., de Anta, R. C., Couteaux, M., Escudero, A., Gallardo, A., Kratz, W., Madeira, M., Mälkönen, E., McClaugherty, C., Meentemeyer, V., Muñoz, F., Piussi, P., Remacle, J., \& de Santo, A. V. (1993). Litter mass loss rates in pine forests of Europe and Eastern United States: some relationships with climate and litter quality. Biogeochemistry, 20, 127159.

Brinkmann, K., Blaschke, L., \& Polle, A. (2002). Comparison of different methods for lignin determination as a basis for calibration of near-infrared reflectance spectroscopy and implications of lignoproteins. Journal of Chemical Ecology, $28,2483-501$. 
Castellano, M. J., Mueller, K. E., Olk, D. C., Sawyer, J. E., \& Six, J. (2015). Integrating plant litter quality, soil organic matter stabilization, and the carbon saturation concept. Global Change Biology, 21, 3200-3209.

Chang, E. R., Veeneklaas, R. M., Bakker, J. P., Daniels, P., \& Esselink, P. (2016) What factors determined restoration success of a salt marsh ten years after deembankment? Applied Vegetation Science, 19, 66-77.

Charles, H., \& Dukes, J. S. (2009). Effects of warming and altered precipitation on plant and nutrient dynamics of a New England salt marsh. Ecological Applications, 19, 1758-1773.

Chmura, G., Chase, P., \& Bercovitch, J. (1997). Climatic Controls of the Middle Marsh Zone in the Bay of Fundy. Estuaries, 20, 689-699.

Chmura, G. L., Anisfeld, S. C., Cahoon, D. R., \& Lynch, J. C. (2003). Global carbon sequestration in tidal, saline wetland soils. Global Biogeochemical Cycles, 17(4), 1-12.

Cornelissen, J. H. C., Van Bodegom, P. M., Aerts, R., Callaghan, T. V., Van Logtestijn, R. S. P., Alatalo, J., Stuart Chapin, F., Gerdol, R., Gudmundsson, J., Gwynn-Jones, D., Hartley, A. E., Hik, D. S., Hofgaard, A., Jónsdóttir, I. S., Karlsson, S., Klein, J. A., Laundre, J., Magnusson, B., Michelsen, A., Molau, U., Onipchenko, V. G., Quested, H. M., Sandvik, S. M., Schmidt, I. K., Shaver, G. R., Solheim, B., Soudzilovskaia, N. A., Stenström, A., Tolvanen, A., Totland, Ø., Wada, N., Welker, J. M., Zhao, X., Brancaleoni, L., Brancaleoni, L., De Beus, M. A. H., Cooper, E. J., Dalen, L., Harte, J., Hobbie, S. E., Hoefsloot, G., Jägerbrand, A., Jonasson, S., Lee, J. A., Lindblad, K., Melillo, J. M., Neill, C., Press, M. C., Rozema, J., \& Zielke, M. (2007). Global negative vegetation feedback to climate warming responses of leaf litter decomposition rates in cold biomes. Ecology Letters, 10, 619-627.

Cotrufo, M. F., Wallenstein, M. D., Boot, C. M., Denef, K., \& Paul, E. (2013). The Microbial Efficiency-Matrix Stabilization (MEMS) framework integrates plant litter decomposition with soil organic matter stabilization: Do labile plant inputs form stable soil organic matter? Global Change Biology, 19, 988-995.

Cotrufo, M. F., Soong, J. L., Horton, A. J., Campbell, E. E., Haddix, M. L., Wall, D. H., \& Parton, W. J. (2015). Formation of soil organic matter via biochemical and physical pathways of litter mass loss. Nature Geoscience, 8, 776-779. 
Craft, C., Clough, J., Ehman, J., Jove, S., Park, R., Pennings, S., Guo, H., \& Machmuller, M. (2009). Forecasting the effects of accelerated sea-level rise on tidal marsh ecosystem services. Frontiers in Ecology and the Environment, 7, 73-78.

Craig, M. (2015) Long Reach Lane at Long Marsh, Harpswell. 2015 Post Project Monitoring Report; Year 2 of 5. available at: http://digitalcommons.usm.maine.edu/cbep-publications (last access: 20 May 2018).

Crosby, S. C., Sax, D. F., Palmer, M. E., Booth, H. S., Deegan, L. A., Bertness, M. D., \& Leslie, H. M. (2016). Salt marsh persistence is threatened by predicted sealevel rise. Estuarine, Coastal and Shelf Science, 181, 93-99.

Curiel Yuste, J., Baldocchi, D. D., Gershenson, A., Goldstein, A., Misson, L., \& Wong, S. (2007). Microbial soil respiration and its dependency on carbon inputs, soil temperature and moisture. Global Change Biology, 13, 2018-2035.

Davidson, E. A., \& Janssens, I. A. (2006). Temperature sensitivity of soil carbon decomposition and feedbacks to climate change. Nature, 440, 165-173.

Davy, A. J., Brown, M. J. H., Mossman, H. L., \& Grant, A. (2011). Colonization of a newly developing salt marsh: Disentangling independent effects of elevation and redox potential on halophytes. Journal of Ecology, 99, 1350-1357.

Deegan, L. A., Johnson, D. S., Warren, R. S., Peterson, B. J., Fleeger, J. W., Fagherazzi, S., \& Wollheim, W. M. (2012). Coastal eutrophication as a driver of salt marsh loss. Nature, 490, 338-392.

Dijkema, K. S., Kers, A. S., \& Van Duin, W. E. (2010). Salt marshes: applied long-term monitoring salt marshes. Wadden Sea Ecosystem, 26, 35-40.

Djukic, I., Kepfer-Rojas, S., Schmidt, I. K., Larsen, K. S., Beier, C., Berg, B., Verheyen, K., \& TeaComposition. (2018). Early stage litter decomposition across biomes. Science to the Total Environment, 628-629, 1369-1394.

Duboc, O., Dignac, M. F., Djukic, I., Zehetner, F., Gerzabek, M. H., \& Rumpel, C. (2014). Lignin decomposition along an Alpine elevation gradient in relation to physicochemical and soil microbial parameters. Global Change Biology, 20, 2272-2285.

Feng, X., Simpson, A. J., Schlesinger, W. H., \& Simpson, M. J. (2010). Altered microbial community structure and organic matter composition under elevated $\mathrm{CO}_{2}$ and $\mathrm{N}$ fertilization in the duke forest. Global Change Biology, 16, 2104-2116. 
Flemming, B. W., \& Davis, R. A. (1994). Holocene evolution, morphodynamics and sedimentology of the Spiekeroog barrier island system (southern North Sea). Senckenbergia maritima, 24, 117-155.

Gedan, K. B., \& Bertness, M. D. (2009). Experimental warming causes rapid loss of plant diversity in New England salt marshes. Ecology Letters, 12, 842-848.

Haddix, M. L., Paul, E. A., \& Cotrufo, M. F. (2016). Dual, differential isotope labeling shows the preferential movement of labile plant constituents into mineralbonded soil organic matter. Global Change Biology, 22, 2301-2312.

Halupa, P. J., \& Howes, B. L. (1995). Effects of tidally mediated litter moisture content on decomposition of Spartina alterniflora and S. patens. Marine Biology, 123, 379-391.

Hemminga, M. A., \& Buth, G. J. C. (1991). Decomposition in salt marsh ecosystems of the S. W. Netherlands: the effects of biotic and abiotic factors. Vegetatio, 92, 73-83.

Howison, R. A., Olff, H., Steever, R., \& Smit, C. (2015). Large herbivores change the direction of interactions within plant communities along a salt marsh stress gradient. Journal of Vegetation Science, 26, 1159-1170.

Isacch, J., Costa, C., Rodriguez-Gallego, L., Conde, D., Escapa, M., Gagliardini, D., \& Iribarne, O. (2006). Distribution of saltmarsh plant communities associated with environmental factors along a latitudinal gradient on the south-west Atlantic coast. Journal of Biogeography, 33, 888-900.

Janousek, C. N., Buffington, K. J., Guntenspergen, G. R., Thorne, K. M., Dugger, B. D., \& Takekawa, J. Y. (2017). Inundation, vegetation, and sediment effects on litter decomposition in Pacific Coast tidal marshes. Ecosystems, 20, 2014-2015.

Johnson, D. S., Warren, R. S., Deegan, L. A., \& Mozdzer, T. J. (2016). Saltmarsh plant responses to eutrophication. Ecological Applications, 26, 2647-2659.

Kearns, P. J., Angell, J. H., Howard, E. M., Deegan, L. A., Stanley, R. H. R., \& Bowen, J. L. (2016). Nutrient enrichment induces dormancy and decreases diversity of active bacteria in salt marsh sediments. Nature Communications, 7, 1-9.

Keuskamp, J. A., Dingemans, B. J. J., Lehtinen, T., Sarneel, J. M., \& Hefting, M. M. (2013). Tea Bag Index: a novel approach to collect uniform decomposition data across ecosystems. Methods in Ecology and Evolution, 4, 1070-1075. 
Keuskamp, J. A., Feller, I. C., Laanbroek, H. J., Verhoeven, J. T. A., \& Hefting, M. M. (2015a). Short- and long-term effects of nutrient enrichment on microbial exoenzyme activity in mangrove peat. Soil Biology and Biochemistry, 81, 38-47.

Keuskamp, J. A., Hefting, M. M., Dingemans, B. J. J., Verhoeven, J. T. A., \& Feller, I. C. (2015b). Effects of nutrient enrichment on mangrove leaf litter decomposition. Science of the Total Environment, 508, 402-410.

Khan, N. S., Vane, C. H., \& Horton, B. P. (2015). Stable carbon isotope and C/N geochemistry of coastal wetland sediments as a sea-level indicator. Handbook of Sea-Level Research, 1, 295-311.

Kirwan, M. L., \& Blum, L. K. (2011). Enhanced decomposition offsets enhanced productivity and soil carbon accumulation in coastal wetlands responding to climate change. Biogeosciences, 8, 987-993.

Kirwan, M. L., \& Megonigal, J. P. (2013). Tidal wetland stability in the face of human impacts and sea-level rise. Nature, 504, 53-60.

Kirwan, M. L., Guntenspergen, G. R., \& Morris, J. T. (2009). Latitudinal trends in Spartina alterniflora productivity and the response of coastal marshes to global change. Global Change Biology, 15, 1982-1989.

Kirwan, M. L., Langley, J. A., Guntenspergen, G. R., \& Megonigal, J. P. (2013). The impact of sea-level rise on organic matter decay rates in Chesapeake Bay brackish tidal marshes. Biogeosciences, 10, 1869-1876.

Kirwan, M. L., Guntenspergen, G. R., \& Langley, J. A. (2014). Temperature sensitivity of organic-matter decay in tidal marshes. Biogeosciences, 11, 4801-4808.

Knorr, M., Frey, S. D., \& Curtis, P. S. (2005). Nitrogen additions and litter decomposition: A meta analysys. Ecology, 86, 3252-3257.

Kristensen, E., Ahmed, S. I., \& Devol, A. H. (1995). Aerobic and anaerobic decomposition of organic matter in marine sediment: Which is fastest? Limnology Oceanography, 40, 1430-1437.

Latter, P. M., \& Walton, D. W. H. (1988). The cotton strip assay for cellulose decomposition studies in soil: history of the assay and development. Cotton strip assay: an index of decomposition in soils, Grange-over-Sands, UK.

Langley, J. A., \& Megonigal, J. P. (2010). Ecosystem response to elevated $\mathrm{CO}_{2}$ levels limited by nitrogen-induced plant species shift. Nature, 466, 96-99. 
Langley, J. A., Mozdzer, T. J., Shepard, K. A., Hagerty, S. B., \& Megonigal, J. P. (2013). Tidal marsh plant responses to elevated $\mathrm{CO}_{2}$, nitrogen fertilization, and sea level rise. Global Change Biology, 19, 1495-1503.

Lovelock, C. E., Feller, I. C., McKee, K. L., \& Thompson, R. (2005). Variation in mangrove forest structure and sediment characteristics in Bocas del Toro, Panama. Caribbean Journal of Science, 41, 456-464.

Macreadie, P. I., Nielsen, D. A., Kelleway, J. J., Atwood, T. B., Seymour, J. R., Petrou, K., Connolly, R. M., Thomson, A. C., Trevathan-Tackett, S. M., \& Ralph, P. J. (2017). Can we manage coastal ecosystems to sequester more blue carbon? Frontiers in Ecology and the Environment, 15, 206-213.

McKee, K. L., Cahoon, D. R., \& Feller, I. C. (2007). Caribbean mangroves adjust to rising sea level through biotic controls on change in soil elevation. Global Ecology and Biogeography, 16, 545-556.

Mcleod, E., Chmura, G. L., Bouillon, S., Salm, R., Björk, M., Duarte, C. M., Lovelock, C. E., Schlesinger, W. H., \& Silliman, B. R. (2011). A blueprint for blue carbon: toward an improved understanding of the role of vegetated coastal habitats in sequestering $\mathrm{CO}_{2}$. Frontiers in Ecology and the Environment, 9, 552-560.

McTiernan, K. B., Coûteaux, M. M., Berg, B., Berg, M. P., De Anta, R. C., Gallardo, A., Kratz, W., Piussi, P., Remacle, J., \& De Santo, A. V. (2003). Changes in chemical composition of Pinus sylvestris needle litter during decomposition along a European coniferous forest climatic transect. Soil Biology and Biochemistry, 35(6), 801-812.

Morris, J., \& Bradley, P. (1999). Effects of nutrient loading on the carbon balance of coastal wetland sediments. Limnology Oceanography, 44, 699-702.

Morris, J. T., Sundberg, K., \& Hopkinson, C. S. (2013). Salt marsh primary production and its responses to relative sea level and nutrients. Oceanography, 26, 78-84.

Mozdzer, T. J., McGlathery, K. J., Mills, A. L., \& Zieman, J. C. (2014). Latitudinal variation in the availability and use of dissolved organic nitrogen in Atlantic coast salt marshes. Ecology, 95, 3293-3303.

Mueller, P., Jensen, K., \& Megonigal, J. P. (2016). Plants mediate soil organic matter decomposition in response to sea level rise. Global Change Biology, 22, 404414. 
Mueller, P., Granse, D., Nolte, S., Do, H. T., Weingartner, M., Hoth, S., \& Jensen, K. (2017). Top-down control of carbon sequestration: grazing affects microbial structure and function in salt marsh soils. Ecological Applications, 27, 14351450.

Mueller, P., Schile-Beers, L. M., Mozdzer, T. J., Chmura, G. L., Dinter, T., Kuzyakov, Y., de Groot, A. V., Esselink, P., Smit, C., D’Alpaos, A., Ibáñez, C., Lazarus, M., Neumeier, U., Johnson, B., Baldwin, A. H., Yarwood, S. A., Montemayor, D., Yang, Z., Wu, J., Jensen, K., \& Nolte, S. (2018). Tea Bag Index $S$ and $k$ data of tidal wetland sites, https://doi.org/10.1594/PANGAEA.890175, 2018.

Neff, K. P., Rusello, K., \& Baldwin, A. H. (2009). Rapid seed bank development in restored tidal freshwater wetlands. Restoration Ecology, 17, 539-548.

Neumeier, U., \& Cheng, C. (2015). Hydrodynamics and sediment dynamics in an icecovered tidal flat, Coast. Sediments, 1-14.

Nolte, S., Müller, F., Schuerch, M., Wanner, A., Esselink, P., Bakker, J. P., \& Jensen, K. (2013). Does livestock grazing affect sediment deposition and accretion rates in salt marshes? Estuarine, Coastal and Shelf Science, 135, 296-305.

Pendleton, L., Donato, D. C., Murray, B. C., Crooks, S., Jenkins, W. A., Sifleet, S., Craft, C., Fourqurean, J. W., Kauffman, J. B., Marbà, N., Megonigal, P., Pidgeon, E., Herr, D., Gordon, D., \& Baldera, A. (2012). Estimating global “blue carbon” emissions from conversion and degradation of vegetated coastal ecosystems. PLoS One, 7, e43542.

Powers, J. S., Montgomery, R. A., Adair, E. C., Brearley, F. Q., Dewalt, S. J., Castanho, C. T., Chave, J., Deinert, E., Ganzhorn, J. U., Gilbert, M. E., González-Iturbe, J. A., Bunyavejchewin, S., Grau, H. R., Harms, K. E., Hiremath, A., Iriarte-Vivar, S., Manzane, E., De Oliveira, A. A., Poorter, L., Ramanamanjato, J. B., Salk, C., Varela, A., Weiblen, G. D., \& Lerdau, M. T. (2009). Decomposition in tropical forests: A pan-tropical study of the effects of litter type, litter placement and mesofaunal exclusion across a precipitation gradient. Journal of Ecology, 97, 801-811.

Prescott, C. E. (2010). Litter decomposition: What controls it and how can we alter it to sequester more carbon in forest soils? Biogeochemistry, 101, 133-149.

Roner, M., D’Alpaos, A., Ghinassi, M., Marani, M., Silvestri, S., Franceschinis, E., \& Realdon, N. (2016). Spatial variation of salt-marsh organic and inorganic 
deposition and organic carbon accumulation: Inferences from the Venice lagoon, Italy. Advances in Water Resources, 93, 276-287.

Rothwell, J. J., Futter, M. N., \& Dise, N. B. (2008). A classification and regression tree model of controls on dissolved inorganic nitrogen leaching from European forests. Environmental Pollution, 156, 544-552.

Ryan, M. G., Melillo, J. M., \& Ricca, A. (1990). A comparison of methods for determining proximate carbon fractions of forest litter. Canadian Journal of Forest Research, 20, 166-171.

Schile, L. M., Callaway, J. C., Morris, J. T., Stralberg, D., Thomas Parker, V., \& Kelly, M. (2014). Modeling tidal marsh distribution with sea-level rise: Evaluating the role of vegetation, sediment, and upland habitat in marsh resiliency. PLoS One, 9, e88760.

Soil Survey Staff (2014). Keys to soil taxonomy. Lincoln, NE, USA.

Swanson, K. M., Drexler, J. Z., Schoellhamer, D. H., Thorne, K. M., Casazza, M. L., Overton, C. T., Callaway, J. C., \& Takekawa, J. Y. (2014). Wetland Accretion Rate Model of Ecosystem Resilience (WARMER) and its application to habitat sustainability for endangered species in the San Francisco Estuary. Estuarine, Coastal and Shelf Science, 37, 476-492.

Trofymow, J., Moore, T., Titus, B., Prescott, C., Morrison, I., Siltanen, M., Smith, S., Fyles, J., Wein, R., Camiré, C., Duschene, L., Kozak, L., Kranabetter, M., \& Visser, S. (2002). Rates of litter decomposition over 6 years in Canadian forests: influence of litter quality and climate. Canadian Journal of Forest Research, 5, 789-804.

Vasey, M. C., Parker, V. T., Callaway, J. C., Herbert, E. R., \& Schile, L. M. (2012). Tidal wetland vegetation in the San Francisco Bay-Delta Estuary. San Francisco Estuary \& Watershed Science, 10, 1-16.

Yang, Z., Nolte, S., \& Wu, J. (2017). Tidal flooding diminishes the effects of livestock grazing on soil micro-food webs in a coastal saltmarsh. Agriculture, Ecosystems \& Environment, 236, 177-186.

Zhang, D. Q., Hui, D. F., Luo, Y. Q., \& Zhou, G. Y. (2008) Rates of litter decomposition in terrestrial ecosystems: global patterns and controlling factors. Journal of Plant Ecology, 1, 85-93. 


\section{Supplementary material}

Table S4.1 Hydrolysable $(\mathrm{H})$ and mineral fractions of green tea ( $\mathrm{n}=5$ batches) and rooibos tea $(\mathrm{n}=3$ batches $)$ and $\mathrm{C}$ and $\mathrm{N}$ contents $(\mathrm{n}=2$ batches). Samples of each batch were analysed as duplicates.

\begin{tabular}{lcccc}
\hline & \multicolumn{2}{c}{ Green Tea } & \multicolumn{2}{c}{ Rooibos Tea } \\
\cline { 2 - 5 } & this study & original & this study & original \\
\hline${\mathrm{H}\left[\mathrm{g} \mathrm{g}^{-1} \text { ] }\right.}^{0.933 \pm 0.012}$ & $0.842 \pm 0.023$ & $0.676 \pm 0.040$ & $0.552 \pm 0.050$ \\
Total C [\%] & $47.9 \pm 2.8$ & $49.1 \pm 0.1$ & $50.1 \pm 0.7$ & $50.5 \pm 0.3$ \\
Total N [\%] & $3.9 \pm 0.2$ & $4.0 \pm 0.1$ & $1.1 \pm 0.1$ & $1.2 \pm 0.1$ \\
Mineral fraction [ $\mathrm{g} \mathrm{g}^{-1}$ ] & $<0.005$ & $<0.005$ & $<0.001$ & $<0.005$ \\
\hline
\end{tabular}

Table S4.2 Comparisons of $k$ and $S$ between high and low elevated zones within sites. Significant differences based on one-way ANOVA in $k$ and $S$ between zones are indicated by 'H' (value higher in high elevated zone) or 'L' (value higher in low elevated zone) and highlighted in orange or blue, respectively. ' $\mathrm{X}$ ' indicates no significant difference between zones. Difference in elevation between zones $(\Delta \mathrm{el})$ and dominant plant species are presented.

\begin{tabular}{|c|c|c|c|c|c|}
\hline site name & $k$ & $S$ & $\Delta_{\mathrm{el}}(\mathrm{cm})$ & high & ation \\
\hline Dieksanderkoog & $\mathrm{H}$ & $\mathrm{H}$ & 51 & Elymus athericus & Puccinellia maritima \\
\hline Sönke-Nissen-Koog & $\mathrm{X}$ & $\mathrm{H}$ & 18 & Elymus athericus & Puccinellia maritima \\
\hline Spiekeroog & $\mathrm{X}$ & $\mathrm{H}$ & 42 & Festuca rubra & Puccinellia maritima \\
\hline Ameland & $\mathrm{L}$ & $\mathrm{H}$ & NA & Elymus athericus & Spatina anglica \\
\hline Noord-Friesland Buitendijks & $\mathrm{X}$ & $\mathrm{H}$ & 15 & Elymus athericus & Elymus athericus \\
\hline Venice Lagoon & $\mathrm{H}$ & $\mathrm{X}$ & 19 & Sarcocornia fruticosa & Salicornia veneta \\
\hline Rimouski & $\mathrm{L}$ & $\mathrm{H}^{\mathrm{u}}$ & 160 & Plantago maritima & Spartina alterniflora \\
\hline Dipper Harbour & $\mathrm{X}$ & $\mathrm{X}$ & 20 & Plantago maritima & Spartina alterniflora \\
\hline Laws Point & $\mathrm{X}$ & $\mathrm{H}$ & $10-130$ & Spartina patens & Spartina alterniflora \\
\hline TIDE project & $\mathrm{X}$ & $\mathrm{H}$ & $10-130$ & Spartina patens & Spartina alterniflora \\
\hline Patuxent River & $\mathrm{X}$ & $\mathrm{X}$ & 126 & Impatiens capensis & Nuphar lutea \\
\hline Rhode River & $\mathrm{L}$ & $\mathrm{H}^{\mathrm{u}}$ & NA & mixed community & Spartina alterniflora \\
\hline Wachapreague & $\mathrm{X}$ & $\mathrm{H}$ & NA & Distichlis spicata & Spartina alterniflora \\
\hline Coon Island & $\mathrm{L}$ & $\mathrm{H}$ & 68 & Spartina pacifica & Spartina foliosa \\
\hline Rush Ranch & $\mathrm{L}$ & $\mathrm{H}$ & 61 & mixed community & Schoenoplectus acutus \\
\hline Twin Cays & $\mathrm{H}$ & $\mathrm{X}^{\mathrm{u}}$ & NA & Rhizophora mangle (dwarf) & Rhizophora mangle (fringe) \\
\hline Isla Solarte & $\mathrm{X}^{\mathrm{u}}$ & $\mathrm{H}$ & NA & Rhizophora mangle (dwarf) & Rhizophora mangle (fringe) \\
\hline Isla Cristóbal & $\mathrm{X}$ & $\mathrm{H}$ & NA & Rhizophora mangle (dwarf) & Rhizophora mangle (fringe) \\
\hline Isla Popa & $\mathrm{X}$ & $\mathrm{X}$ & NA & Rhizophora mangle (dwarf) & Rhizophora mangle (fringe) \\
\hline Dongtan & $\mathrm{L}$ & $\mathrm{X}$ & 50 & Phragmites australis & Scirpus mariqueter \\
\hline
\end{tabular}

Notes: "Mann-WhitneyU-tests were conducted if data did not meet ANOVA assumptions 
Table S4.1 Overview of mean values for $k$ and $S$ based on the original TBI protocol (Keuskamp et al., 2013) and the modified protocol (present study).

\begin{tabular}{|c|c|c|c|c|c|c|c|c|}
\hline \multirow[b]{3}{*}{ Site name $\downarrow$ relative elevation $\rightarrow$} & \multicolumn{4}{|c|}{$\mathrm{H}$ following original TBI protocol } & \multicolumn{4}{|c|}{$\mathrm{H}$ following modified protocol } \\
\hline & \multicolumn{2}{|c|}{ stabilization $(S)$} & \multicolumn{2}{|c|}{ decomp. rate $(k)$} & \multicolumn{2}{|c|}{ stabilization $(S)$} & \multicolumn{2}{|c|}{ decomp. rate $(k)$} \\
\hline & high & low & high & low & high & low & high & low \\
\hline Dieksanderkoog & 0.194 & 0.107 & 0.037 & 0.018 & 0.273 & 0.194 & 0.025 & 0.014 \\
\hline Sönke-Nissen-Koog & 0.188 & -0.081 & 0.022 & 0.017 & 0.259 & 0.024 & 0.016 & 0.014 \\
\hline Spiekeroog & 0.546 & 0.297 & 0.007 & 0.005 & 0.460 & 0.353 & 0.006 & 0.005 \\
\hline Ameland & -0.047 & -0.088 & 0.014 & 0.017 & 0.112 & 0.077 & 0.014 & 0.016 \\
\hline Noord-Friesland Buitendijks & 0.230 & 0.135 & 0.023 & 0.026 & 0.275 & 0.220 & 0.015 & 0.017 \\
\hline Schiermonnikoog & -0.003 & NA & 0.008 & NA & 0.095 & NA & 0.007 & NA \\
\hline Venice Lagoon & 0.260 & 0.256 & 0.007 & 0.003 & 0.324 & 0.329 & 0.006 & 0.002 \\
\hline Vilacoto & 0.337 & NA & 0.031 & NA & 0.401 & NA & 0.019 & NA \\
\hline Garxal & 0.347 & NA & -0.001 & NA & 0.411 & NA & -0.001 & NA \\
\hline Alfacs & NA & 0.219 & NA & 0.008 & NA & 0.295 & NA & 0.007 \\
\hline Mechelińskie Łąki & 0.161 & NA & 0.017 & NA & 0.243 & NA & 0.013 & NA \\
\hline Rimouski & 0.625 & 0.383 & -0.003 & 0.003 & 0.661 & 0.443 & -0.003 & 0.003 \\
\hline Dipper Harbour & 0.262 & 0.069 & 0.012 & 0.010 & 0.334 & 0.160 & 0.010 & 0.009 \\
\hline Long Marsh, north of inlet & 0.242 & NA & 0.004 & NA & 0.316 & NA & 0.003 & NA \\
\hline Long Marsh, south of inlet & 0.189 & NA & 0.007 & NA & 0.268 & NA & 0.006 & NA \\
\hline Long Marsh, south of Narrows & 0.195 & NA & 0.007 & NA & 0.273 & NA & 0.006 & NA \\
\hline Laws Point & -0.027 & -0.043 & 0.012 & 0.012 & 0.073 & 0.058 & 0.010 & 0.010 \\
\hline TIDE project & -0.009 & -0.069 & 0.010 & 0.012 & 0.089 & 0.035 & 0.008 & 0.014 \\
\hline Patuxent River & -0.096 & -0.074 & 0.017 & 0.016 & 0.012 & 0.034 & 0.013 & 0.013 \\
\hline Rhode River & -0.091 & -0.120 & 0.015 & 0.020 & 0.016 & -0.011 & 0.012 & 0.015 \\
\hline Wachapreague & 0.020 & -0.086 & 0.013 & 0.014 & 0.116 & 0.020 & 0.011 & 0.012 \\
\hline Coon Island & 0.105 & 0.012 & 0.010 & 0.018 & 0.192 & 0.102 & 0.008 & 0.014 \\
\hline Rush Ranch & 0.082 & -0.013 & 0.012 & 0.017 & 0.171 & 0.086 & 0.010 & 0.013 \\
\hline China Camp & 0.098 & NA & 0.011 & NA & 0.186 & $\mathrm{NA}$ & 0.009 & NA \\
\hline Twin Cays & -0.002 & 0.003 & 0.011 & 0.010 & 0.096 & 0.102 & 0.009 & 0.009 \\
\hline Isla Solarte & -0.025 & -0.050 & 0.011 & 0.011 & 0.075 & 0.053 & 0.010 & 0.010 \\
\hline Isla Cristóbal & -0.023 & -0.069 & 0.012 & 0.011 & 0.081 & 0.041 & 0.010 & 0.009 \\
\hline Isla Popa & -0.046 & -0.064 & 0.013 & 0.013 & 0.056 & 0.039 & 0.011 & 0.011 \\
\hline Mar Chiquita & 0.162 & 0.310 & 0.006 & 0.008 & 0.244 & 0.377 & 0.005 & 0.007 \\
\hline Dongtan & -0.027 & -0.029 & 0.013 & 0.013 & 0.073 & 0.071 & 0.011 & 0.011 \\
\hline
\end{tabular}


Tree graph for $\mathbf{k}$

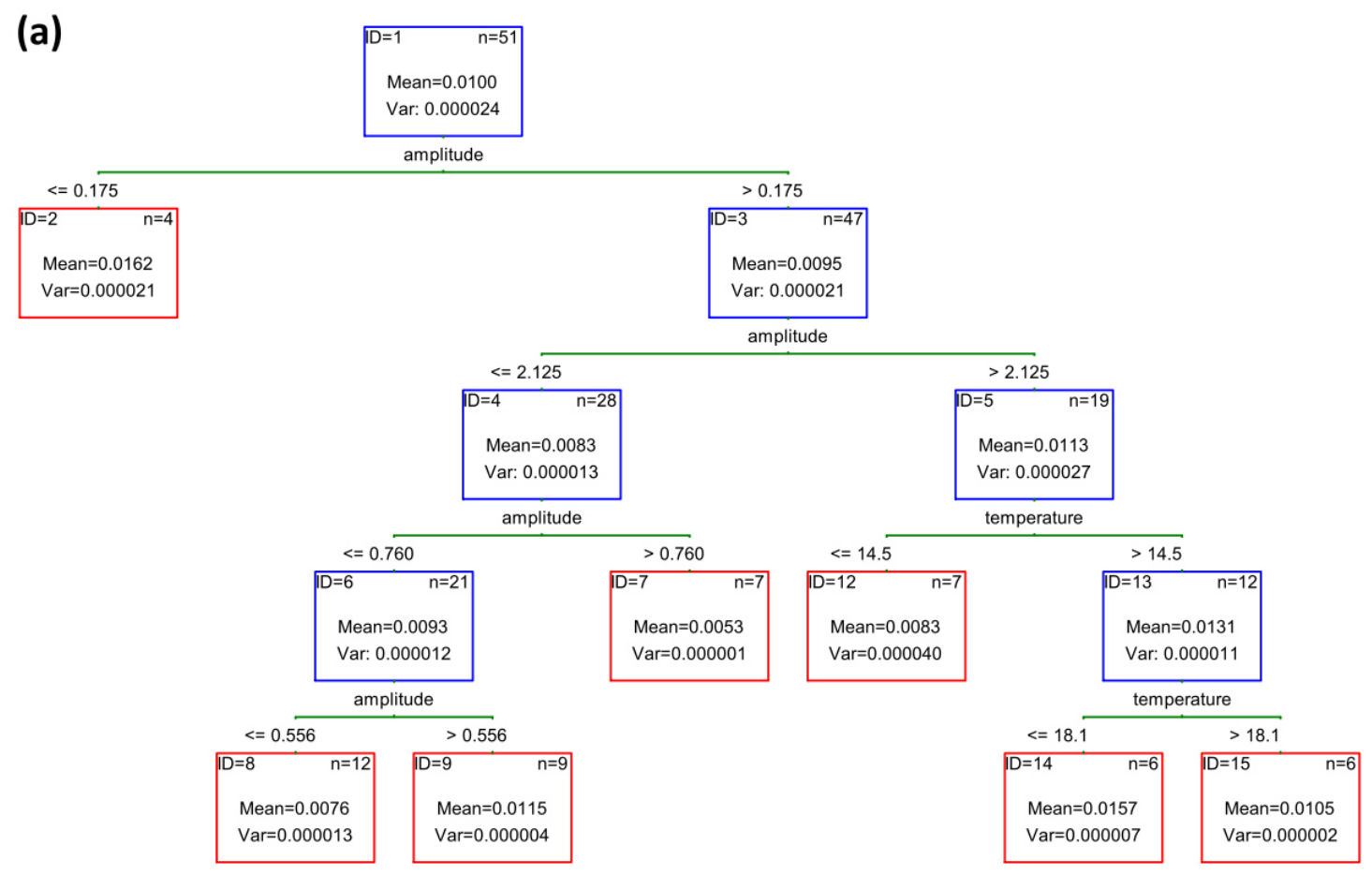

\section{Tree graph for S}

(b)

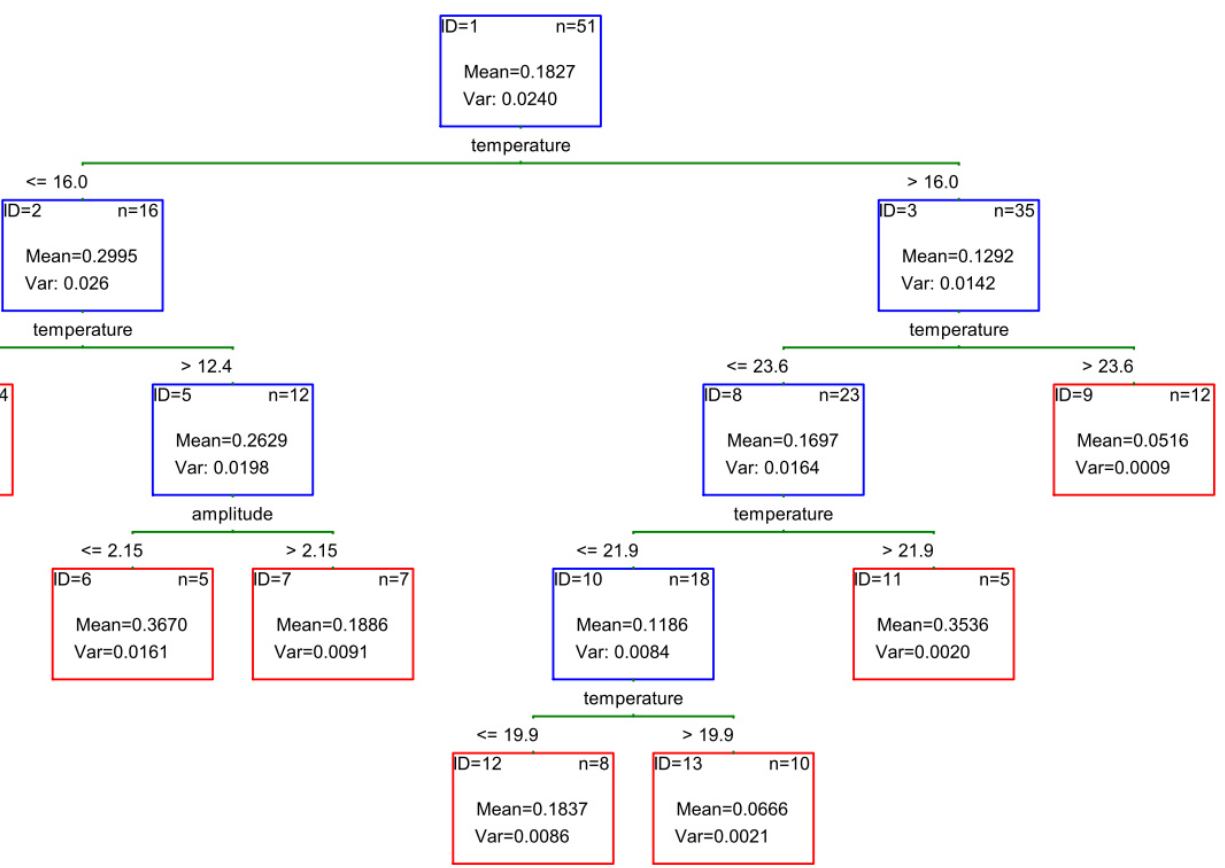

Figure S4.1 Data mining: Classification and regression trees (CART) for (a) decomposition rate and (b) stabilisation. Step-wise splitting of the data set was conducted based on the predictor variables temperature, tidal amplitude, salinity class, soil type, ecosystem type, and elevation zone. CART was conducted with mean values of each site by elevation zone combination $(n=51)$. Minimum size of child nodes was set at 4 , corresponding to at least two sites; V-fold cross validation was set at 5. 


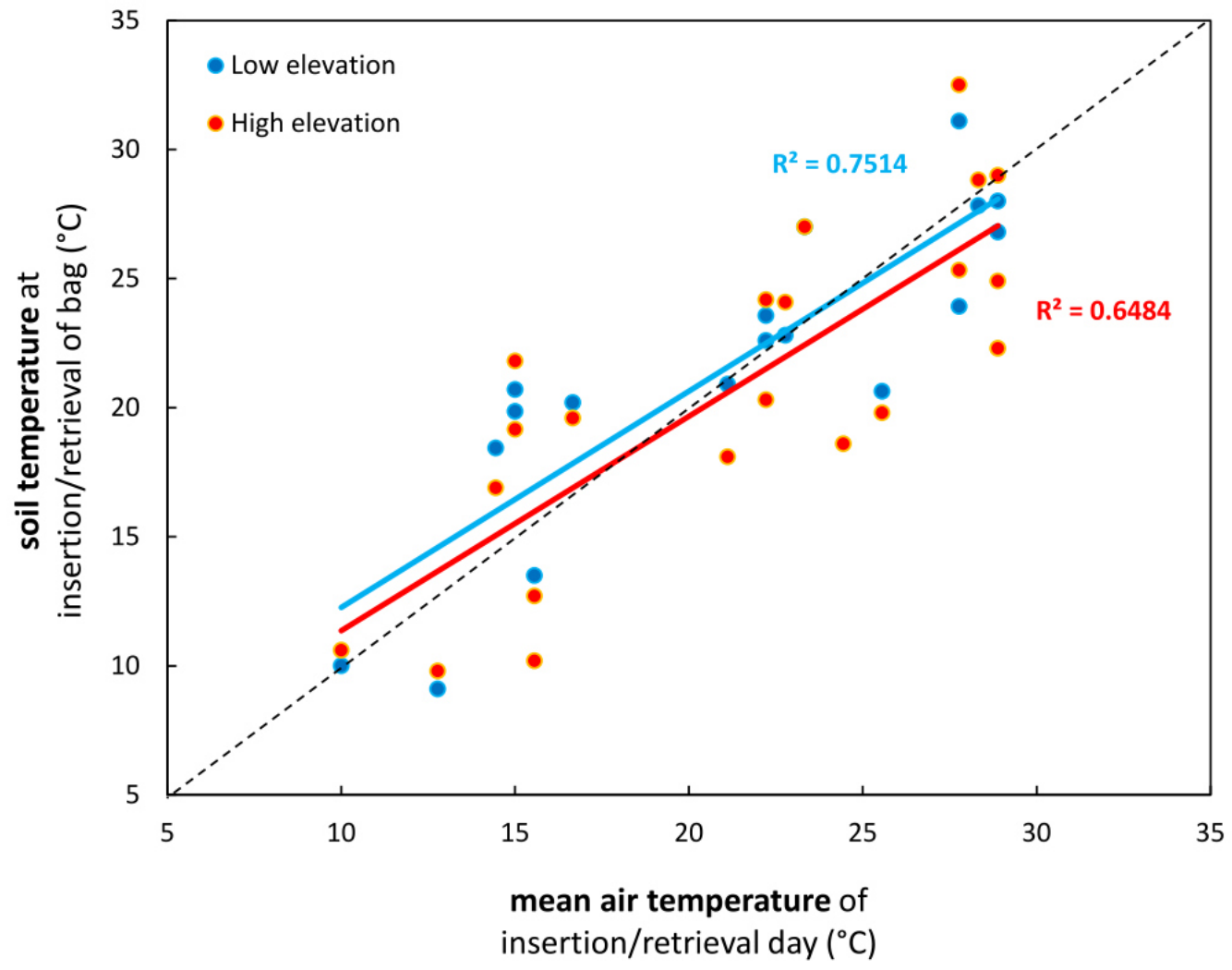

Figure S4.2 Mean air temperature of insertion/retrieval day of tea bags (as obtained from the closest station of the AccuWeather service) versus soil temperature at the time point of insertion/retrieval of tea bags (assessed in 14 sites) in high and low elevated zones. Additional statistics: paired t-test comparing difference of air versus soil temperature between paired high and low elevated zones: $\mathrm{p}=0.56$; paired $t$-test comparing soil temperature between paired high and low elevated zones: $\mathrm{p}=0.34$. 
Chapter 4 


\section{Chapter 5}

\section{Effects of inundation, nutrient availability and plant species diversity on fine root mass and morphology across a salt marsh flooding gradient}

Regine Redelstein, Thomas Dinter, Dietrich Hertel, Christoph Leuschner

Published in Frontiers in Plant Science, 9, 98, 2018,

https://doi.org/10.3389/fpls.2018.00098

Author contributions

RR and TD took the samples and prepared them for measurement; RR, TD and DH analysed the data; RR drafted the main manuscript in collaboration with CL 


\section{Abstract}

Salt marsh plants are exposed to multiple stresses including tidal inundation, salinity, wave action and sediment anoxia, which require specific root system adaptations to secure sufficient resource capture and firm anchorage in a temporary toxic environment. It is well known that many salt marsh species develop large belowground biomass (roots and rhizomes) but relations between fine roots, in particular, and the abiotic conditions in salt marshes are widely unknown. We studied fine root mass ( $<2 \mathrm{~mm}$ in diameter), fine root depth distribution and fine root morphology in three typical communities (Spartina anglica-dominated pioneer zone, Atriplex portulacoides-dominated lower marsh, Elytrigia atherica-dominated upper marsh) across elevational gradients in two tidal salt marshes of the German North Sea coast [a mostly sandy marsh on a barrier island (Spiekeroog), and a silty-clayey marsh on the mainland coast (Westerhever)]. Fine root mass in the $0-40 \mathrm{~cm}$ profile ranged between 750 and 2,500 $\mathrm{g} \mathrm{m}^{-2}$ in all plots with maxima at both sites in the lower marsh with intermediate inundation frequency and highest plant species richness indicating an effect of biodiversity on fine root mass. Fine root mass and, even more, total fine root surface area (maximum $340 \mathrm{~m}^{2} \mathrm{~m}^{-2}$ ) were high compared to terrestrial grasslands, and were greater in the nutrient-poorer Spiekeroog marsh. Fine root density showed only a slight or no decrease toward $40 \mathrm{~cm}$ depth. We conclude that the standing fine root mass and morphology of these salt marshes is mainly under control of species identity and nutrient availability, but species richness is especially influential. The plants of the pioneer zone and lower marsh possess well adapted fine roots and large standing root masses despite the often water-saturated sediment.

Keywords: Diversity effect, Nutrient availability, Root depth distribution, Sediment texture, Specific root area, Tidal inundation gradient 


\subsection{Introduction}

The plants of temperate salt marshes are exposed to multiple stresses such as frequent flooding associated with salinity, temporary anoxia in the sediment, and possibly sulfide and manganese toxicity together with mechanical stress and sediment coverage (Leuschner \& Ellenberg, 2017). Despite these constraints, some salt marsh plants such as cordgrass (Spartina spp.) and sea purslane (Atriplex portulacoides) are known to be highly productive (Smith et al., 1979; Schubauer \& Hopkinson, 1984; Bouchard \& Lefeuvre, 2000). Many salt marsh species develop extensive root systems and it has been found that plant biomass and productivity may be larger below- than above-ground in these environments (Valiela et al., 1976; Smith et al., 1979; Schubauer \& Hopkinson, 1984; Groenendijk \& Vinklievaart, 1987; Tripathee \& Schaefer, 2015). For example, 50-90\% of the productivity of Spartina alterniflora was found to be contributed by root and rhizome growth and turnover in a salt marsh in the eastern United States (Valiela et al., 1976; Darby \& Turner, 2008). This suggests that a large part of the soil organic carbon contained in salt marsh sediments is derived from roots, and below-ground productivity is an important factor in the carbon and nutrient cycles of these semi-aquatic ecosystems. Due to their short lifespan and rapid turnover, fine and very fine roots (diameters $<2 \mathrm{~mm}$ ) act as an important sink for carbohydrates supplied by photosynthesis (Jackson et al., 1997; Gill \& Jackson, 2000). However, most studies on the salt marsh below-ground compartment focus on the total (i.e., fine and coarse root, and rhizome) biomass, while only few studies have addressed the structure and dynamics of roots $<2 \mathrm{~mm}$ in diameter, i.e., the fraction of the root system which likely is responsible for water and nutrient uptake.

Coastal salt marshes are extreme habitats, which require specific adaptations of the plants that colonise them. Species growing in the frequently inundated lower zone of the marsh have to cope with anoxia and reducing conditions in the soil. This environment may trigger the formation of aerenchyma in roots and rhizomes, which facilitate oxygen supply, and foster the development of strategies to exclude and excrete salt (Rozema et al., 1981, 1985). Root aerenchyma can increase the plant's capacity to detoxify potentially harmful ions such as $\mathrm{S}^{2-}, \mathrm{Fe}^{2+}$ or $\mathrm{Mn}^{2+}$ in the rhizosphere (Lee, 1999, 2003; Maricle \& Lee, 2002). In the upper marsh, stress from inundation is less frequent, but plant growth may additionally be limited by nitrogen 
shortage (Valiela \& Teal, 1974; Kiehl et al., 1997; Levine et al., 1998; van Wijnen \& Bakker, 1999). The large below-ground biomass often found in salt marshes is thus not surprising, as it may be needed to secure nutrient and water acquisition, and to anchor the plants in a relatively unstable sediment. Root/shoot mass ratios exceeding unity are also found in other stressful environments such as nutrient-poor or dry grasslands and cold tundra ecosystems (Jackson et al., 1996; Leuschner et al., 2013).

Small-scale heterogeneity is a characteristic feature of many temperate salt marsh ecosystems. Even minor elevation differences in the salt marsh may cause great spatial differences in inundation frequency, water level height, salinity and the degree of soil anoxia, and thus in the conditions for root growth in the sediment. This is also reflected in the zonation of salt marsh communities (Bakker, 2014; Leuschner \& Ellenberg, 2017), with salinity and tidal inundation as the main factors driving species distribution across the elevation gradient (Cooper, 1982; Armstrong et al., 1985; Rozema et al., 1985; Ungar, 1998).

Root system studies across elevation and water level gradients and in different sediment types should reflect the small-scale vegetation mosaic in salt marshes and may display the associated plant strategies to cope with varying environmental constraints. An example illustrating species differences is the study of Bouma et al. (2002) in a Dutch salt marsh, who found root longevity to be shorter in the highly competitive upper marsh grass Elytrigia atherica than in the more stress-tolerant grass Spartina anglica from the lowermost pioneer zone. Results of Steudel et al. (2011) and Ford et al. (2016) suggest that plant species richness, which can vary between one species per plot at the most stressful sites and more than 10 species at higher elevation, could also influence the root mass of salt marsh communities, modifying the influence of abiotic factors. Also for other ecosystems it is known that plant diversity increases root biomass (Mommer et al., 2010; Mueller et al., 2013; Eisenhauer et al., 2017). Resource capture in more diverse communities may for example be enhanced by adjusting the depth distribution of roots between species (i.e., "complementarity effect"; Loreau \& Hector, 2001; Cardinale et al., 2007; Mommer et al., 2010). Furthermore, the "selection effect" may increase biomass production in more diverse communities, as a very productive species dominates the biomass of the species mixture (Loreau \& Hector, 2001). 
In this study, we examined the variation in fine root mass, fine root depth distribution and fine root morphology across elevational gradients in two common types of North Sea tidal salt marshes, a barrier island marsh with mostly sandy sediment and a foreland salt marsh with silty-clayey sediment. Due to these differences in geomorphology, sites assumedly differ in nutrient availability and further soil properties, such as bulk density, enabling the investigation of these parameters on fine root traits. The variation in elevation and inundation frequency was addressed by transects reaching from the low-elevation pioneer zone with dominant Spartina stands with daily inundation to the high-elevation upper salt marsh with dominant Elytrigia swards that experience flooding only 4-8 times per month. We focused on fine roots $<2 \mathrm{~mm}$ in diameter due to their relevance for resource uptake, while larger roots and rhizomes with primarily storage, conduction and anchorage function were not considered. We searched for those abiotic and biotic factors (inundation frequency, salinity, soil texture, soil nutrient and element content, species diversity), which exert the largest influence on fine root mass and morphology in the studied salt marshes. We tested the hypotheses that (i) fine root mass is on average greater in the sandy than the silty sediments due to higher nutrient availability in the latter, (ii) the decrease of rooting depth with increasing soil depth is less pronounced in the pioneer zone due to an assumed greater adaptive potential of the inhabiting species to the anoxic sediment conditions, (iii) the likely more stress-tolerant species of the frequently inundated pioneer zone have more robust roots with lower specific root area (SRA) and specific root length (SRL), but higher root tissue density (RTD) than the more competitive species of the upper marsh, and (iv) plant species richness has a positive effect on the root mass of the community.

\subsection{Materials and methods}

\section{Study sites}

Sampling was conducted in late September (i.e., toward the end of the growing season) at two salt marsh sites of the German North Sea coast (Figure 5.1A): one site was located on the south coast of Spiekeroog Island (Lower Saxony, 53 $45^{\prime} 44^{\prime \prime} \mathrm{N} 7^{\circ}$ $43^{\prime} 23$ "E), the second site was located in a salt marsh in the Tümlau Bay close to Westerhever (Schleswig-Holstein, 54 $22^{\prime} 22^{\prime \prime} \mathrm{N} 8^{\circ} 38^{\prime} 47^{\prime \prime}$ E). Sites differ in terms 
of geomorphology: Spiekeroog is a barrier island with marshes on the leeward side developed on a base layer of sand on which a thin layer of silt has been deposited (Bakker, 2014). This marsh has developed naturally in the shelter of sand dunes and is not grazed by livestock. In contrast, the foreland salt marsh in Westerhever is located on the mainland coast on the seaward side of an artificial dike and has developed on a fine-grained sediment consisting of a thick (0.5-0.8 m) clayey silt layer (Peiter, 2004). This salt marsh was drained in the early twentieth century and has been intensively grazed until 1991 (Stock et al., 2005).

In both salt marshes, six plots of $2 \mathrm{~m} \times 2 \mathrm{~m}$ size were installed in each of the three salt marsh zones resulting in a total of 18 plots per site. Zones differed in elevation relative to sea level and thus inundation frequency and inhabiting salt marsh communities (Figure 5.1B). The pioneer zone is inundated by most tides except the lowest neap tides and the dominant species is Spartina anglica C.E. Hubb., accompanied by Salicornia stricta Dumort., Suaeda maritima (L.) Dumort., Aster tripolium L., and Puccinellia maritima (Huds.) Parl.. The subsequent lower salt marsh, inundated less frequently only by spring tides, is the most species-rich community with high cover of Atriplex portulacoides L. and Puccinellia maritima and occurrence of Cochlearia danica L., Suaeda maritima, Limonium vulgare Mill., Artemisia maritima L., Aster tripolium, Triglochin maritima L., Plantago maritima L. s. str., Salicornia europaea L. S. str., Spartina anglica and Spergularia media (L.) C. Presl at lower frequency. The upper salt marsh is inundated only during very high spring tides and storm events and is dominated by Elytrigia atherica (Link) Kerguélen with a few individuals of Atriplex prostrata Boucher ex DC. 


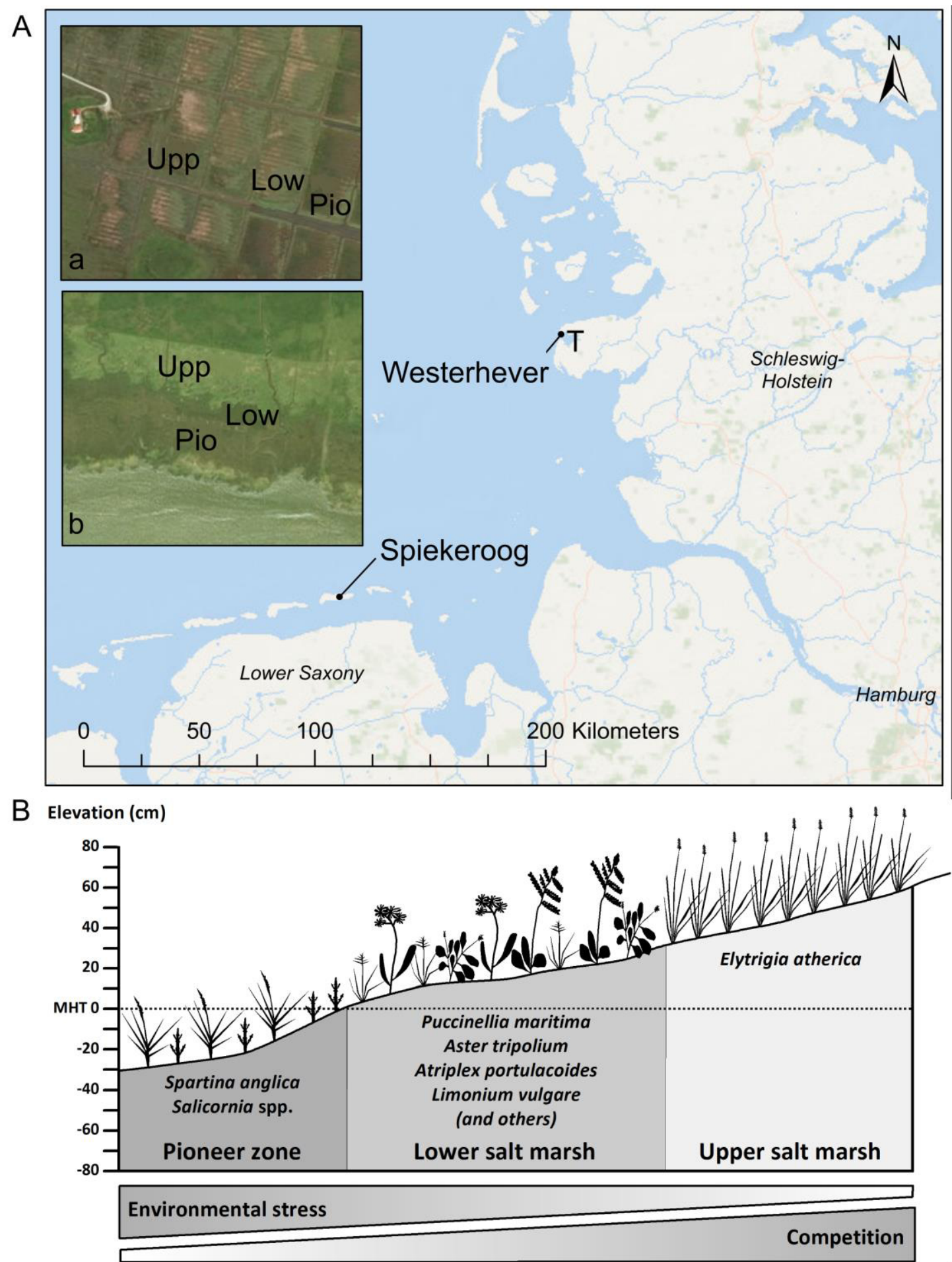

Figure 5.1 (A) Map of the German North Sea coast with the location of the two study sites Spiekeroog Island and Westerhever and location of the sampling plots in the three salt marsh zones pioneer zone (Pio), lower salt marsh (Low), and upper salt marsh (Upp). Detail maps: Tümlau Bight in Westerhever (a) and south side of Spiekeroog Island (b). "'T' marks the location of the tide gauge station" from which water level data for Westerhever were obtained (Service layer Credits: Esri, DeLorme, GEBCO, NOAA NGDB, and other contributors, Source: Esri, DigitalGlobe, GeoEye, Earthstar Geographics, CNES/Airbus DS, USDA, USGS, AeroGRID, IGN, and the GIS User Community). (B) Zonation of a salt marsh with elevations relative to the mean high tide (MHT) water level and species typically inhabiting the three zones in a north-west European salt marsh. 


\section{Tidal inundation and soil properties}

To measure water level variation and the frequency of tidal inundations of the plots, a RBRduo | TD wave sensor (RBR Ltd., Ontario, Canada) was installed on the tidal flat of Spiekeroog and its elevation determined relative to the height of the salt marsh plots using a differential GPS. For the Westerhever site, data on water level fluctuation were provided from the nearby gauge station Tümlau AP (Figure 5.1A) by the Schleswig-Holstein Agency for Coastal Protection, National Park and Marine Conservation. The elevation of the Westerhever salt marsh site is specified in Stock (2012). Inundation frequency and flooding duration of the three community types were calculated from the data on water level fluctuation and plot elevation.

From each plot, two soil samples for chemical analysis were taken, separated into the upper Ah/Ai-horizon (mineral horizon of the topsoil with accumulation of humus (h) or initial humus development in the pioneer zone (i); $\sim 0-20 \mathrm{~cm}$ depth) and the lower Go/Gr-horizon (horizon affected by groundwater, oxidised (o) or reduced (r); > $20 \mathrm{~cm}$ depth) and combined to one pooled sample per soil horizon. For the analysis of grain size, an aliquot ( $5 \mathrm{~g})$ of dried soil $\left(105^{\circ} \mathrm{C}\right)$ was used. To account for organic substances, carbonates and iron-oxides, samples were treated with $\mathrm{H}_{2} \mathrm{O}_{2}, \mathrm{HCl}$ and Na-Dithionite prior to analysis. Particles $>20 \mu \mathrm{m}$ were separated using sieves of different mesh sizes whereas particles $<20 \mu \mathrm{m}$ were separated by performing Atterberg cylinder analysis of sinking velocity. The remaining soil was dried at $40{ }^{\circ} \mathrm{C}$ until constant weight and used for chemical analyses. Samples were sieved to $2 \mathrm{~mm}$ and ground in a ball mill (200 rpm for $5 \mathrm{~min}$ ). One aliquot of a sample was digested with $65 \% \mathrm{HNO}_{3}$ (Heinrichs et al., 1986) and total element contents (Al, $\mathrm{Ca}, \mathrm{Fe}, \mathrm{K}, \mathrm{Mg}, \mathrm{Mn}, \mathrm{Na}, \mathrm{P}, \mathrm{S}$ ) were determined using Inductively Coupled PlasmaOptical Emission Spectroscopy (ICP-OES, iCAP 6300 Duo View ICP Spectrometer, Thermo Fisher Scientific GmbH, Dreieich, Germany). From another aliquot, inorganic carbon was removed by treatment with $1 \mathrm{M} \mathrm{HCl}$; this sample was dried at $50{ }^{\circ} \mathrm{C}$ and analysed for organic carbon (Corg) and total nitrogen ( $\mathrm{Nt}$ ) using a $\mathrm{C} / \mathrm{N}$ elemental analyser (Flash 2000, Thermo Fisher Scientific, Cambridge, UK). A third aliquot was used for determination of plant-available phosphorous according to Schüller (1969): $5 \mathrm{~g}$ of soil were added to $100 \mathrm{ml}$ of calcium-acetate-lactate (CAL)-solution and shaken automatically for 90 min. Extracts were filtered into Falcon R Tubes, whereby the first $5 \mathrm{ml}$ were discarded, and stored at $4{ }^{\circ} \mathrm{C}$ until further analysis no longer than $24 \mathrm{~h}$. 
Plant-available phosphorous was measured photometrically as a molybdate-complex using a microplate reader at $820 \mathrm{~nm}$ wavelength. For the analysis of mineral nitrogen $\left(\mathrm{NO}^{3-}\right.$ and $\left.\mathrm{NH}^{4+}\right)$, a further aliquot of fresh soil was immediately frozen after sampling. $20 \mathrm{ml}$ of a $2.5 \mathrm{M} \mathrm{K}_{2} \mathrm{SO}_{4}$ solution were added to $5 \mathrm{~g}$ of fresh soil and thoroughly mixed for $30 \mathrm{~s}$. Samples were shaken for $2 \mathrm{~h}$ on an overhead shaker and finally filtered through a Whatman (no. 2) filter. Concentrations of ammonium and nitrate in the extracts were determined using a continuous flow injection colorimeter (Cenco/Skalar Instruments, Breda, The Netherlands)

\section{Sampling and processing of fine roots and aboveground biomass}

For the inventory of fine root mass, samples were taken with a stainless steel corer (35 mm diameter, $400 \mathrm{~mm}$ length) on all plots to a depth of $40 \mathrm{~cm}$. Soil cores were divided into depth intervals of $0-5 \mathrm{~cm}, 5-10 \mathrm{~cm}, 10-20 \mathrm{~cm}$, and $20-40 \mathrm{~cm}$ and the samples were stored frozen until processing in the laboratory. The sediment material was washed over a sieve with $200 \mu \mathrm{m}$ mesh size to separate roots from finest-grained sediment. Under a stereomicroscope the roots were further cleaned and separated from rhizomes and other organic material. Only fine roots $<2 \mathrm{~mm}$ in diameter were considered for analysis. After the extraction of larger fine root fragments $(>1 \mathrm{~cm}$ length), the remaining sediment with small rootlets was evenly distributed on a sheet of filter paper subdivided into 36 squares according to Hertel and Leuschner (2002). Six of the squares were randomly selected and all fine root fragments in the squares collected quantitatively under a binocular. The dry mass of these subsamples was extrapolated to the 36 squares to estimate the total mass of finest rootlets in the sample. In selected subsamples, we separated dead from living fine root material under the microscope to estimate the fraction of living fine roots. A non-turgid stele and periderm, the loss of the stele, or differing root colour and elasticity were used as indicators of root death. Since the proportion of dead fine roots was $<10 \%$ in all samples, we decided to refrain from distinguishing between dead and live roots in every sample in order to process a larger number of replicate samples. Thus, all data refer to total fine root mass which consists to $>90 \%$ of biomass

Root morphological traits were determined by scanning the extracted roots on a flatbed scanner. Total root length, root surface area, root volume and root diameter were measured using the software WinRhizo (Régent Instruments, Quebec, Canada). After scanning, roots were oven dried at $70{ }^{\circ} \mathrm{C}$ for $72 \mathrm{~h}$ and weighed to 
determine dry mass. Specific root length (SRL, root length/dry weight), specific root area (SRA, root surface area/dry weight) and root tissue density (RTD, dry weight/root volume) were calculated from these measurements. Cumulative root surface area (Root Area Index, RAI) was calculated from SRA and fine root mass for a specific plot. For analysing the $\mathrm{C}$ and $\mathrm{N}$ content of root mass, the dried roots were ground in a vibrating disc mill and a subsample of $5 \mathrm{mg}$ was analysed in a $\mathrm{C} / \mathrm{N}$ elemental analyser by gas chromatography (vario EL III; elementar, Hanau, Germany).

The percentage cover of all species in the $2 \mathrm{~m} \times 2 \mathrm{~m}$ plots was estimated with the Londo scale to the next $10 \%$ ( $>10 \%$ cover) or $1 \%(<10 \%$ cover $)$. Plant species diversity in the $4 \mathrm{~m}^{2}$ plots was expressed by Shannon's H. Aboveground biomass was sampled in all plots by randomly placing a square of $10 \mathrm{~cm} \times 10 \mathrm{~cm}$ in the plot and cutting all plant stems directly at the soil surface inside the square. Biomass was separated from necromass, cleaned in the laboratory, dried at $70{ }^{\circ} \mathrm{C}$ for $72 \mathrm{~h}$ and weighed.

\section{Statistical analysis}

Statistical analyses were conducted using R 3.3.2 software (R Development Core Team, 2016). One-way Analysis of Variance (ANOVA) with Tukey's HSD test was applied for multiple comparisons between salt marsh communities and sites (ANOVA and HSD-test, packages "car" and "agricolae," respectively). Where normality of residuals and homoscedasticity were not given, values were log-transformed to meet these requirements. When assumption of normality could not be achieved, we used the Kruskal-Wallis test (kruskalmc, package "pgirmess") for multiple comparisons between communities and sites. Welch's two sample t-test was used for comparisons between soil horizons. Step-wise multiple linear regressions with forward and backward variable selection were carried out with the "MASS" package to identify the best predictor variables for fine root mass. The initial model included total phosphorous content, mineral nitrogen content, Shannon's H, aboveground biomass, and the soil Na and S content; the final model was selected by means of minimum AIC. A significance level of $\mathrm{p}<0.05$ was used throughout. A principal components analysis (PCA) was conducted with the software CANOCO, version 5.02 (Biometris, the Netherlands) to analyse inter-relationships between fine root mass and morphology, and soil properties across the different salt marsh communities and sites. 


\subsection{Results}

\section{Tidal inundation regime, soil properties, and plant species diversity}

Due to the local tidal flat morphology, the pioneer zone plots in Spiekeroog were more frequently inundated than those in Westerhever (46 vs. 20 flooding events per month), whereas flooding events in the upper salt marsh occurred less frequently than in Westerhever ( 4 vs. 8 events per month; Table 5.1). The inundation frequency gradient from the pioneer zone to the upper salt marsh was thus steeper in the Spiekeroog transect.

The two study sites also differed with respect to sediment texture and chemistry (Table 5.1, Supplementary Material S5.1). The Spiekeroog site was characterised by a larger sand but smaller silt fraction in both the uppermost (Ah) and lower sediment layers (Go/Gr horizon) compared to the generally finer textured Westerhever site $(\mathrm{p}<0.05)$. An exception was the very silt- and clay-rich Ah horizon in the upper salt marsh of Spiekeroog. While the Westerhever sediment profiles were relatively uniform in terms of grain size distribution, the Spiekeroog profiles were clearly stratified with a distinct increase in the sand fraction from the Ah to the lower Go/Gr horizon $(\mathrm{p}<0.05)$. This was reflected in a significant $(\mathrm{p}<0.05)$ decrease in the mineral $\mathrm{N}$ and plant-available $\mathrm{P}$ content of the soil as well as in the $\mathrm{Na}$ and $\mathrm{S}$ contents toward the subsoil in Spiekeroog; this decrease was not as pronounced in Westerhever. At both sites, the grain size composition did not differ significantly between the pioneer, lower and upper salt marsh zone. While the total $\mathrm{N}$ content of the sediment was similar across sites, the soil organic carbon content of the sediment and the related $\mathrm{C} / \mathrm{N}$-ratio tended to be higher in Westerhever (significant in the topsoil of the pioneer zone and lower salt marsh, $\mathrm{p}<0.05$ ). While plant-available $\mathrm{P}$ was detected with significantly higher concentrations in the Westerhever sediments $(\mathrm{p}<0.05)$, especially in the topsoil, the $\mathrm{K}_{2} \mathrm{SO}_{4}$-exchangeable nitrate and ammonium concentrations in Westerhever were higher in the deeper soil than in Spiekeroog $(\mathrm{p}<0.05)$. The total $\mathrm{Na}$ and $\mathrm{S}$ contents were particularly high in the frequently inundated pioneer zone of Spiekeroog and decreased toward the upper salt marsh in both soil horizons $(\mathrm{p}<0.05)$.

At both sites, the lower salt marsh zones showed greatest plant species richness (10 species per plot at both sites) and Shannon diversity (H': 0.56 at 
Spiekeroog and 0.33 at Westerhever), whereas species richness and diversity in the upper salt marsh were lowest (2 species per plot; H': 0.02 at Spiekeroog and 0.03 at Westerhever). Mean species number in the pioneer zone plots was 4 (Spiekeroog) and 7 (Westerhever) and Shannon's H was 0.2 (Spiekeroog) and 0.27 (Westerhever) (Supplementary Material S5.2).

\section{Fine Root and Aboveground Biomass and Their Dependence on Environmental Factors and Plant Diversity}

Total fine root mass $(0-40 \mathrm{~cm})$ was at both sites greatest in the lower salt marsh $\left(2,547 \mathrm{~g} \mathrm{~m}^{-2}\right.$ in Spiekeroog and 2,379 $\mathrm{g} \mathrm{m}^{-2}$ in Westerhever $)$ and smallest in the upper salt marsh (1,579 $\mathrm{g} \mathrm{m}^{-2}$ in Spiekeroog and $759 \mathrm{~g} \mathrm{~m}^{-2}$ in Westerhever). However, this difference was only significant in Westerhever $(\mathrm{p}<0.05)$. Aboveground biomass decreased in Spiekeroog from the pioneer zone $\left(1,048 \mathrm{~g} \mathrm{~m}^{-2}\right)$ to the upper salt marsh (481 $\mathrm{g} \mathrm{m}^{-2}$ ) community (difference not significant), while it peaked in Westerhever in the lower salt marsh $\left(2,376 \mathrm{~g} \mathrm{~m}^{-2}\right)$, which was significantly greater than in the pioneer zone $\left(1,134 \mathrm{gm}^{-2}, \mathrm{p}<0.05\right)$. Differences between the two sites in aboveground biomass in a given zone were larger than for fine root mass. In the Westerhever salt marsh, aboveground biomass was generally larger than in Spiekeroog on the sandy sediment (significant for the lower and upper salt marsh, $\mathrm{p}<0.05$ ) (Figure 5.2).

The ratio of fine root mass/aboveground biomass was in all communities at both sites greater than unity (except for the upper salt marsh in Westerhever), and reached a maximum of 4.8 in the lower salt marsh of Spiekeroog (Table 5.2). The ratio was generally greater in Spiekeroog than in Westerhever; this difference between sites was significant in the lower and upper salt marsh but diminished in the pioneer zone $(\mathrm{p}<0.05)$. Root area index (RAI, i.e., total fine root surface area) in the sediment to $40 \mathrm{~cm}$ was at both sites greatest in the lower salt marsh (335 and $205 \mathrm{~m}^{2} \mathrm{~m}^{-2}$ in Spiekeroog and Westerhever, respectively, Figure 5.3). 


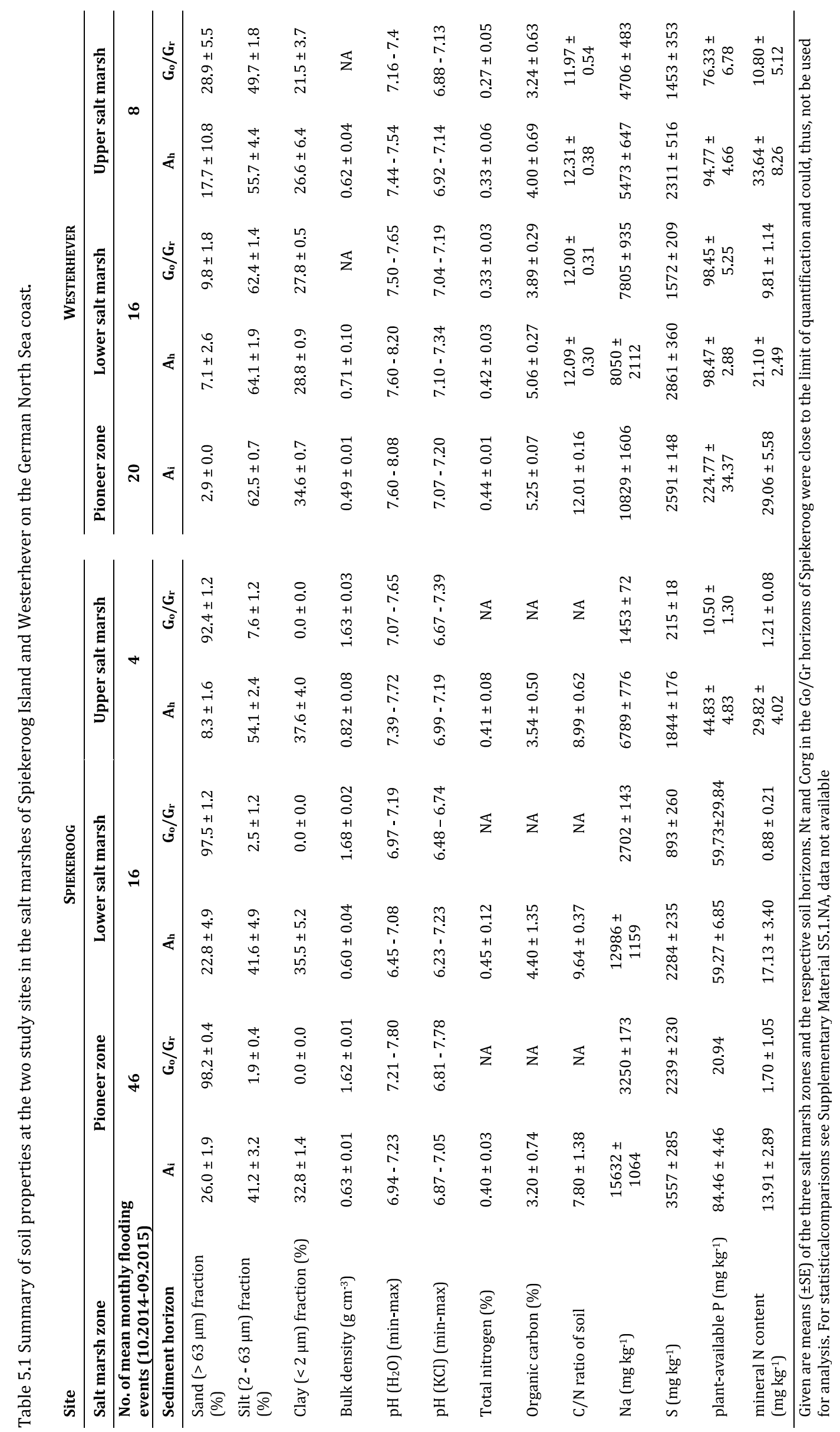



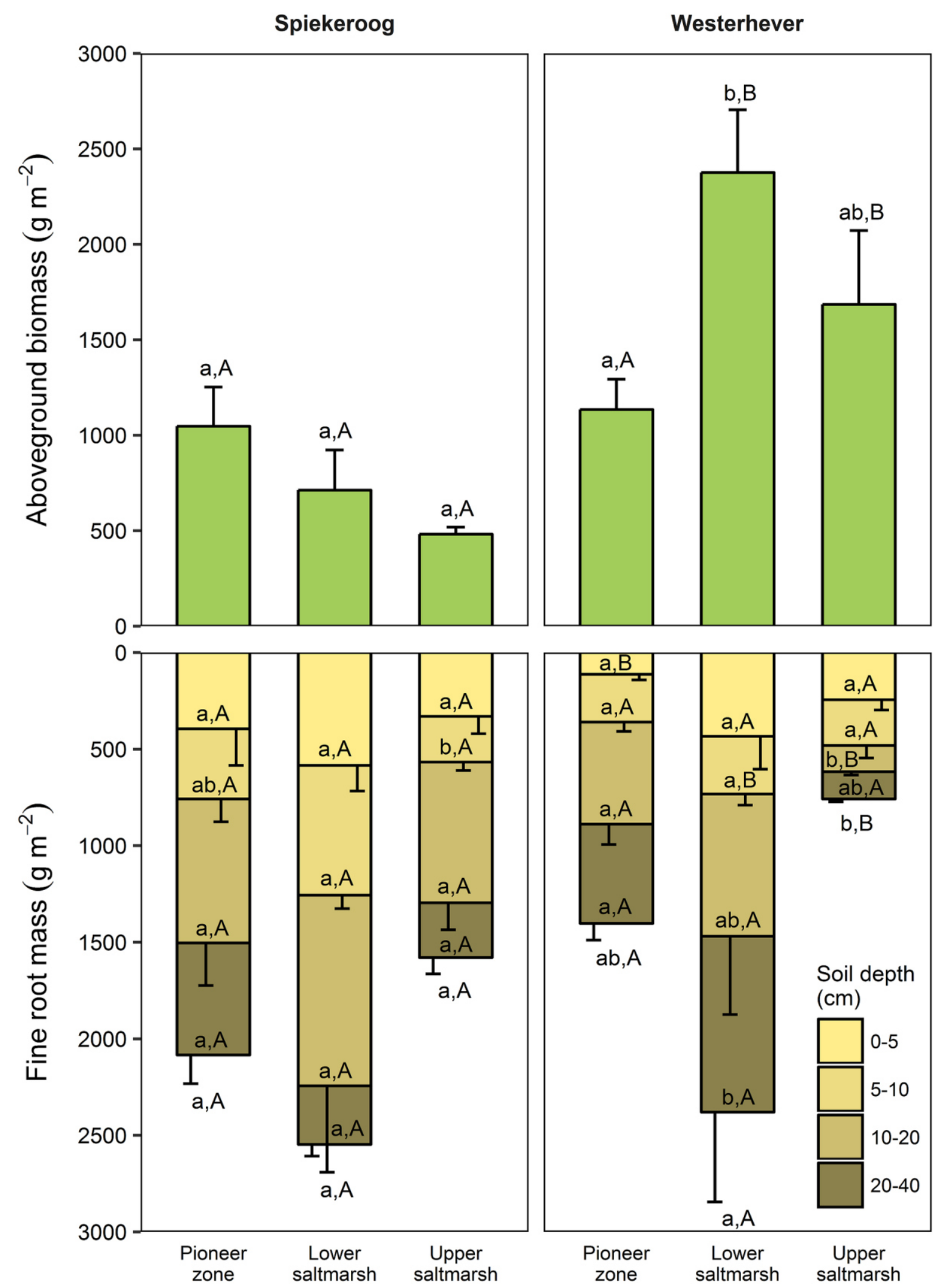

Figure 5.2 Aboveground biomass and fine root mass in the three salt marsh communities at the two study sites (n $=6$, means $\pm S E)$. Different letters indicate significant differences between communities at a site $(\mathrm{a}, \mathrm{b})$ or between the sites within a community type $(A, B)$ (Kruskal-Wallis multiple comparison test, $p<0.05$ ).Letters inside the bars indicate significant differences for different sediment horizons, letters below bars stand for the entire soil profile. 
Table 5.2 Fine root mass/aboveground biomass ratio (median values) in the three salt marsh zones at both study sites.

\begin{tabular}{lccc}
\hline $\begin{array}{l}\text { Root/shoot } \\
\text { ratio biomass }\end{array}$ & Pioneer zone & Lower salt marsh & Upper salt marsh \\
\hline Spiekeroog & $1.85^{\mathrm{a}, \mathrm{A}}$ & $4.76^{\mathrm{a}, \mathrm{A}}$ & $3.52^{\mathrm{a}, \mathrm{A}}$ \\
Westerhever & $1.15^{\mathrm{a}, \mathrm{A}}$ & $1.20^{\mathrm{a}, \mathrm{B}}$ & $0.57^{\mathrm{a}, \mathrm{B}}$ \\
\hline
\end{tabular}

Different letters indicate significant differences between zones within a site (a) or between sites within a zone $(A, B)$ analysed by Kruskal-Wallis multiple comparisons $(\mathrm{p}<0.05)$

In the pioneer zone and upper salt marsh communities, RAI was significantly greater in Spiekeroog than in Westerhever (125 vs. 62 and 206 vs. $48 \mathrm{~m}^{2} \mathrm{~m}^{-2}$ in the pioneer zone and upper salt marsh, respectively; $\mathrm{p}<0.05$ ).

\section{Vertical fine root distribution}

The density of fine roots (root mass per soil volume) decreased with increasing depth in the sediment at both sites and in all communities (Figure 5.4). The decrease from the topsoil $(0-5 \mathrm{~cm})$ to the subsoil $(20-40 \mathrm{~cm})$ was, however, significant only in some cases (Westerhever: upper and lower salt marsh, Spiekeroog: upper salt marsh; Kruskal-Wallis multiple comparison test, $\mathrm{p}<0.05$, data not shown). At $10 \mathrm{~cm}$ soil depth, there was a remarkable difference in fine root density in the lower salt marsh with very high values in Spiekeroog (13.5 $\mathrm{g} \mathrm{dm}^{-3}$ ) compared to Westerhever $\left(6 \mathrm{~g} \mathrm{dm}^{-3}\right)$. At both sites, the pioneer zone held the lowest percentage of roots in the upper $20 \mathrm{~cm}$ of soil, i.e., the highest percentage of deep-reaching roots (significant for Westerhever, $\mathrm{p}<0.05$, Table 5.3).

Table 5.3 Percentage of fine root mass in the upper $20 \mathrm{~cm}$ of soil of the total soil profile $(0-40 \mathrm{~cm})(\mathrm{means} \pm \mathrm{SE}$, $\mathrm{n}=6)$.

\begin{tabular}{lccc}
\hline $\begin{array}{l}\text { Percentage root } \\
\text { mass in upper } \\
\text { 20 cm of soil }\end{array}$ & Pioneer zone & $\begin{array}{c}\text { Lower salt } \\
\text { marsh }\end{array}$ & $\begin{array}{c}\text { Upper salt } \\
\text { marsh }\end{array}$ \\
\hline Spiekeroog & $69.48 \pm 4.88^{\mathrm{a}, \mathrm{A}}$ & $86.16 \pm 2.75_{\mathrm{a}, \mathrm{A}}$ & $82.88 \pm 3.54 \mathrm{a}, \mathrm{A}$ \\
Westerhever & $64.08 \pm 3.88^{\mathrm{a}, \mathrm{A}}$ & $66.05 \pm 7.65^{\mathrm{ab}, \mathrm{B}}$ & $81.26 \pm 1.71^{\mathrm{b}, \mathrm{A}}$ \\
\hline
\end{tabular}

Different letters indicate significant differences between zones within a site $(a, b)$ or between sites within a zone $(A, B)$ analysed by Kruskal-Wallis multiple comparisons $(\mathrm{p}<0.05)$. 


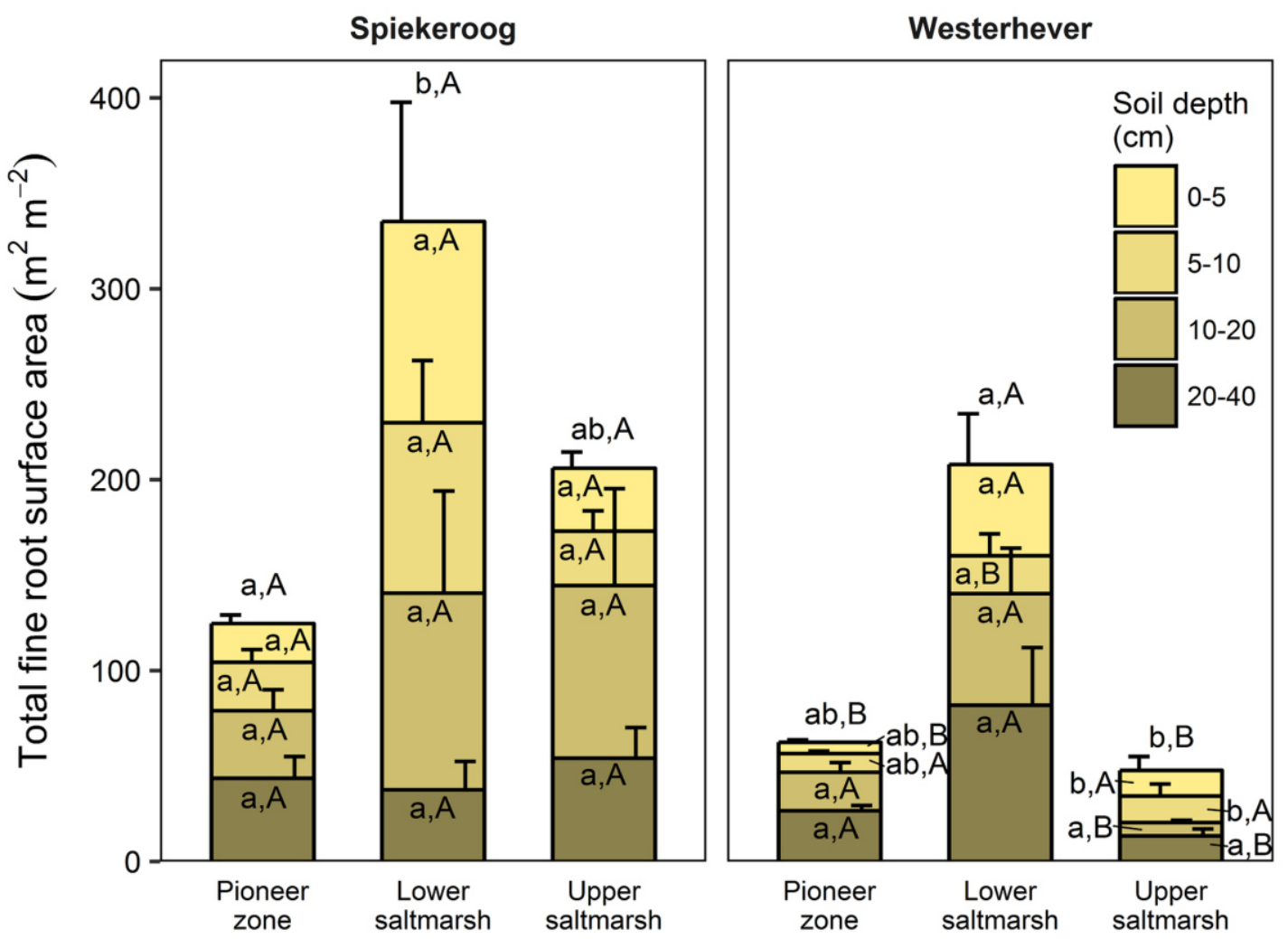

Figure 5.3 Cumulative fine root surface area per $\mathrm{m}^{2}$ ground area in the profile to $40 \mathrm{~cm}$ depth in the three salt marsh communities at the study sites Spiekeroog and Westerhever $(n=6$, means \pm SE). Different letters indicate significant differences between the communities at a site $(a, b)$ or between the two sites for a community type $(A, B)$ according to Kruskal-Wallis multiple comparison tests $(p<0.05)$. Letters inside of the bars indicate significant differences for a given sediment horizon, letters above bars stand for the entire soil profile.

\section{Relation between fine root mass and environmental factors and plant} diversity

Stepwise multiple regression analysis with the variables total $\mathrm{Na}, \mathrm{P}, \mathrm{S}$, and mineral N content in the sediment, Shannon diversity and aboveground biomass in the initial model revealed that Shannon diversity had a highly significant effect $(\mathrm{p}<0.001)$ on fine root mass (Table 5.4). This effect had a higher explanatory power than that of mineral $\mathrm{N}$ content in the sediment $(\mathrm{p}<0.01)$ and also of the Na content as a proxy of the inundation regime $(\mathrm{p}<0.05)$. The prominent role of the influence of plant diversity disappeared when the root mass in the lower Go/Gr horizon was considered. Here, soil chemical parameters ( $\mathrm{Na}$ and total $\mathrm{P}$ content) were the only influential factors $(\mathrm{p}<0.01)$. 


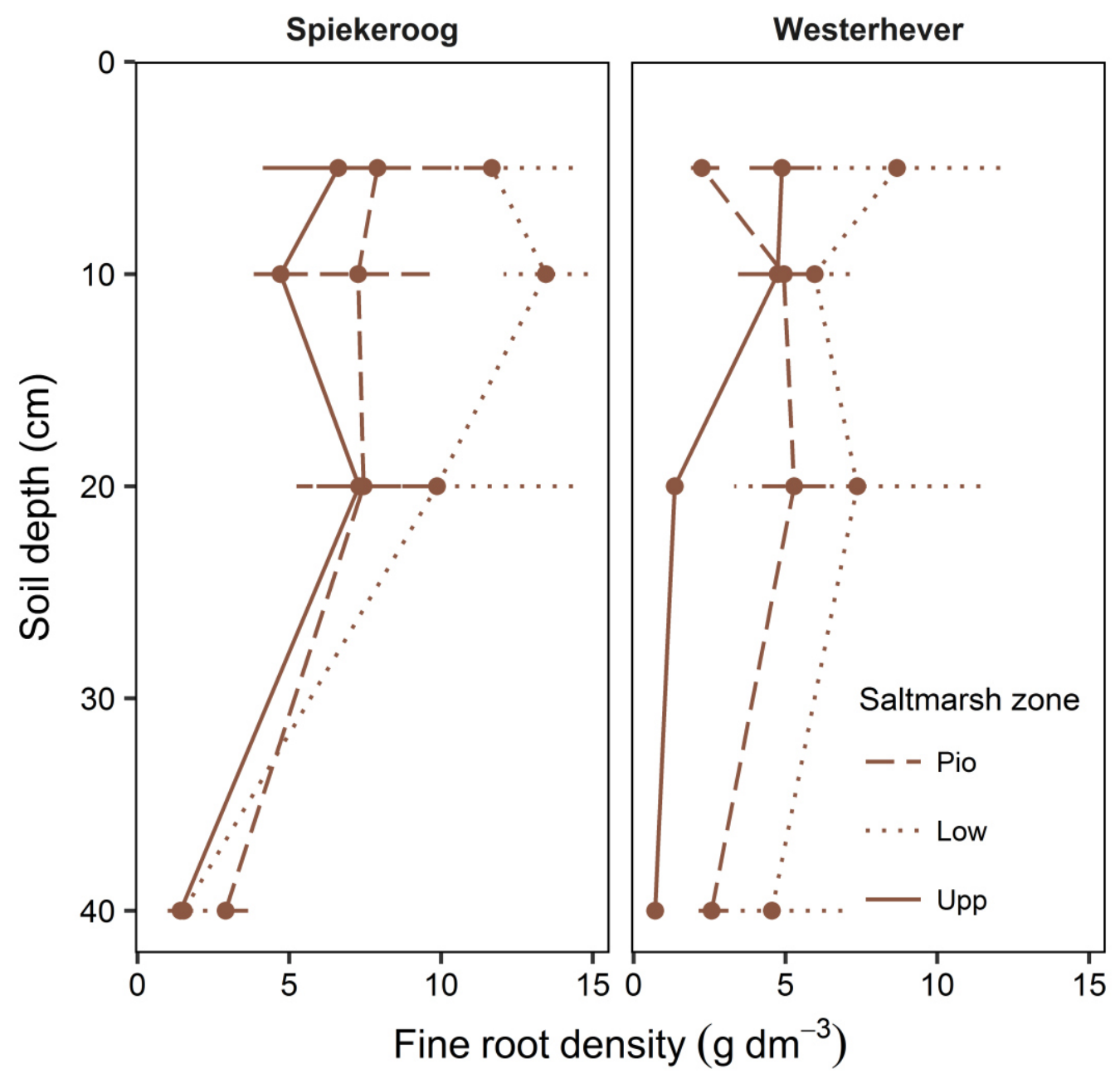

Figure 5.4 Change in fine root density (fine root mass per soil volume) with soil depth in the three salt marsh communities (Pio, pioneer zone; Low, lower salt marsh; Upp, upper salt marsh) at the study sites Spiekeroog and Westerhever $(n=6$, means \pm SE).

\section{Root Morphological and Chemical Traits}

SRL and SRA ranged between 46 and $120 \mathrm{~m} \mathrm{~g}^{-1}$ and between 455 and 1,546 $\mathrm{cm}^{2} \mathrm{~g}^{-1}$, respectively, in all studied plots (Figure 5.5). Significant differences between zones $(p<0.05)$ were only found in Westerhever, where the highest SRL was found in the lower salt marsh. RTD ranged from 0.17 to $0.34 \mathrm{~g} \mathrm{~cm}^{-3}$ with particularly high values in the pioneer zone and upper salt marsh of Westerhever. Significant site differences existed for SRL, SRA (lower values in Westerhever) and RTD (higher values in Westerhever) in the pioneer zone and the upper salt marsh community $(p<0.05)$. Root diameter was relatively uniform across the plots $(0.3-0.4 \mathrm{~mm})$ with no site - and community-specific differences. Root nitrogen concentrations differed between all three communities at both sites $(\mathrm{p}<0.05)$. They were highest in the lower salt marsh of both sites (16.7 and $14.1 \mathrm{mg} \mathrm{g}^{-1}$ in Spiekeroog and Westerhever, respectively) and 


\section{Chapter 5}

lowest in the upper salt marsh of Spiekeroog (12.4 $\left.\mathrm{mg} \mathrm{g}^{-1}\right)$ and the pioneer zone of Westerhever (10.9 $\mathrm{mg} \mathrm{g}^{-1}$ ). Particularly high values were found in the pioneer zone and lower salt marsh of Spiekeroog (significant difference to Westerhever, $\mathrm{p}<0.05$ ).

Table 5.4 Predictor variables for fine root mass identified by stepwise multiple regression analyses (forward and backward variable selection) grouped by study site and soil depth.

\begin{tabular}{|c|c|c|c|c|}
\hline Model variables & Estimate & se & t-value & $p$-value \\
\hline \multicolumn{5}{|c|}{ Best model fit: both study sites, all soil depths (AIC $\left.=-92.75, F=11.46, d f=3,58, p<0.001, R^{2}=0.37\right)$} \\
\hline (Intercept) & 7.23 & $1.2410^{-1}$ & 58.44 & $* * *$ \\
\hline $\mathrm{Na}$ & $2.4910^{-5}$ & $1.2310^{-5}$ & 2.02 & $*$ \\
\hline mineral $\mathrm{N}$ & $1.3110^{-2}$ & $4.1210^{-3}$ & -3.18 & ** \\
\hline Shannon-Wiener index, $\mathrm{H}$ & 1.01 & $2.8210^{-1}$ & 3.57 & $* * *$ \\
\hline \multicolumn{5}{|c|}{ Best model fit: Spiekeroog, all soil depths (AIC $\left.=-79.18, F=9.68, d f=2,33, p<0.001, R^{2}=0.37\right)$} \\
\hline (Intercept) & 7.23 & 0.11 & 68.51 & $* * *$ \\
\hline Shannon-Wiener index, $\mathrm{H}$ & 0.80 & 0.20 & 4.03 & $* * *$ \\
\hline aboveground biomass & 0.00 & 0.00 & 1.62 & n.s. \\
\hline \multicolumn{5}{|c|}{ Best model fit: Westerhever, all soil depths (AIC $\left.=-27.12, F=6.10, d f=4,21, p<0.01, R^{2}=0.54\right)$} \\
\hline (Intercept) & 6.15 & $3.4310^{-1}$ & 17.92 & *** \\
\hline $\mathrm{Na}$ & $8.8110^{-5}$ & $3.6810^{-5}$ & 2.39 & * \\
\hline Shannon-Wiener index, H & 1.80 & $7.5310^{-1}$ & 2.39 & * \\
\hline aboveground biomass & $2.9310^{-4}$ & $1.3910^{-4}$ & 2.11 & * \\
\hline total S & $-2.210^{-4}$ & $1.4310^{-4}$ & -1.54 & n.s. \\
\hline \multicolumn{5}{|c|}{ Best model fit: both study sites, $A_{h}$ horizon (AIC $=-48.39, F=6.90, d f=3,30, p<0.01, R^{2}=0.41$ ) } \\
\hline (Intercept) & 7.36 & $2.4010^{-1}$ & 30.60 & $* * *$ \\
\hline mineral $\mathrm{N}$ & $-1.3810^{-2}$ & $5.8810^{-3}$ & -2.35 & * \\
\hline Shannon-Wiener index, $\mathrm{H}$ & 1.05 & $3.8010^{-1}$ & 2.76 & $* *$ \\
\hline aboveground biomass & $-1.6910^{-4}$ & $9.0010^{-5}$ & -1.79 & n.s. \\
\hline \multicolumn{5}{|c|}{ Best model fit: both study sites, $G_{o} / G_{r}$ horizon $\left(A I C=-13.29, F=4.05, d f=3,24, p<0.05, R^{2}=0.34\right.$ ) } \\
\hline (Intercept) & 5.05 & 0.28 & 18.343 & $* * *$ \\
\hline $\mathrm{Na}$ & $0.2910^{-3}$ & $0.1010^{-3}$ & 2.80 & ** \\
\hline total $\mathrm{P}$ & $-1.8510^{-3}$ & $0.6010^{-3}$ & -3.06 & ** \\
\hline aboveground biomass & $0.3210^{-3}$ & $0.2410^{-3}$ & 1.34 & n.s. \\
\hline
\end{tabular}




\section{Principal Components Analysis}

Ordination of the 36 plots with PCA based on the studied soil and root-related parameters confirmed the differentiation among the two study sites and three salt marsh zones (Figure 5.6, Table 5.5). For the topsoil data $(0-20 \mathrm{~cm})$, the first axis (eigenvalue 0.48$)$ separated the two study sites, and associated fine root mass, SRA, root/shoot ratio, RAI and root $\mathrm{N}$ concentration with the Spiekeroog site, whereas mineral N content, RTD and soil silt fraction were more closely associated with the Westerhever site. The second axis (eigenvalue 0.23 ) separated the three salt marsh communities along a gradient of decreasing distance to the ocean. Mineral $\mathrm{N}$ as well as SRA were associated with this axis in the direction of the upper salt marsh, whereas on the opposite side, flooding frequency, $\mathrm{S}, \mathrm{Na}$ and plant-available $P$ contents of the soil were associated with this axis in the direction of the pioneer zone. The differences between the two study sites in terms of soil nutrient content in association with sediment texture were even clearer in the deeper sediment horizon (20$40 \mathrm{~cm}$ ) than in the topsoil (Supplementary Material S5.3).
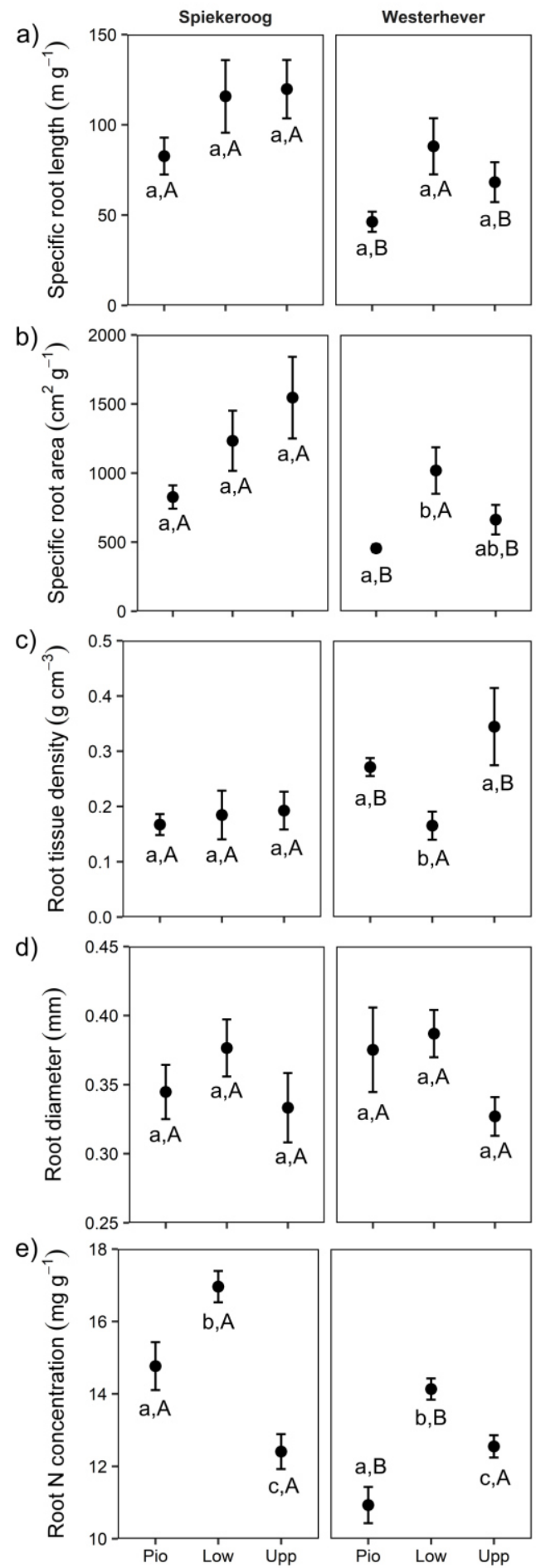

Figure 5.5 Means \pm SE of five fine root morphological traits (a), Specific root length; b) Specific root area; c), Root tissue density; d) Root diameter; e), Root $\mathrm{N}$ concentration) in the three salt marsh communities (Pio, pioneer zone; Low, lower salt marsh; Upp, upper salt marsh) at the study sites Spiekeroog and Westerhever $(n=24)$. Different letters indicate significant differences between study sites and salt marsh communities according to one-way ANOVA with Tukey's post-hoc test $(\mathrm{p}<0.05)$. 


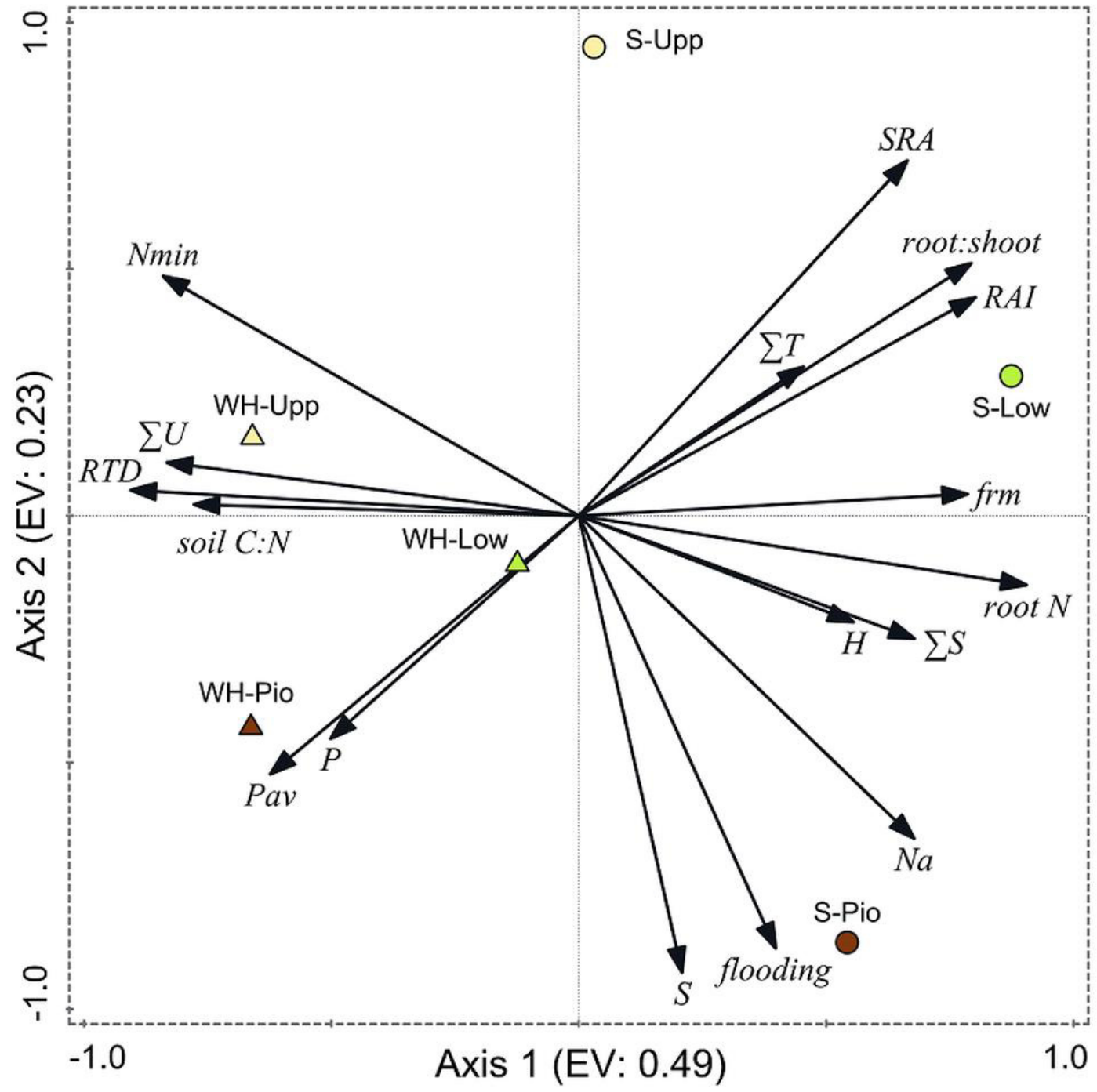

Figure 5.6 Plot showing the distribution of the three salt marsh communities (Pio, pioneer zone; Low, lower salt marsh; Upp, upper salt marsh) of the two sites Spiekeroog (S) and Westerhever (WH) in relation to the PCA axes 1 and 2 (EV: eigenvalues of the axes) and their association with important soil and root properties (SRA, specific root area; $\sum \mathrm{T}$, clay fraction; RAI, root area index; FRM, fine root mass; root $\mathrm{N}$, root $\mathrm{N}$ concentration; $\sum \mathrm{S}$, sand fraction; $\mathrm{H}$, Shannon-Wiener index; $\mathrm{Na}, \mathrm{Na}_{\mathrm{t}}$ concentration in the sediment; flooding, no. of monthly flooding events; P, total P in the sediment; Pav, plant-available P in the sediment; RTD, root tissue density; $\sum \mathrm{U}$, silt fraction; Nmin, mineral $\mathrm{N}$ concentration $\left(\mathrm{NO}^{-3}\right.$ and $\left.\mathrm{NH}^{+4}\right)$ in soil) in the upper soil horizon (Ah). Vector length and angle are proportional to the direction and degree of their correlation with the plot ordination scores. 
Table 5.5 Results of a Principal Components Analysis (PCA) on the differentiation of the three salt marsh zones at both study sites with respect to fine root mass, root morphological traits, species diversity and soil properties of the Ah-horizon.

\begin{tabular}{lcc}
\hline & $\begin{array}{c}\text { Axis 1 } \\
\text { (EV 0.4855) }\end{array}$ & $\begin{array}{c}\text { Axis 2 } \\
\text { (EV 0.2342) }\end{array}$ \\
\hline fine root mass & $\mathbf{0 . 7 9}(0.62)$ & $0.04(0.62)$ \\
fine root/shoot ratio & $\mathbf{0 . 7 9}(0.63)$ & $\mathbf{0 . 5 1}(0.89)$ \\
specific root area & $0.66(0.44)$ & $\mathbf{0 . 7 2}(0.96)$ \\
root tissue density & $\mathbf{- 0 . 9 1}(0.82)$ & $0.05(0.82)$ \\
root N concentration & $\mathbf{0 . 9 0}(0.82)$ & $-0.14(0.84)$ \\
root surface area & $\mathbf{0 . 8 0}(0.64)$ & $0.44(0.84)$ \\
total Na in soil & $0.68(0.46)$ & $\mathbf{- 0 . 6 5}(0.89)$ \\
total P in soil & $-0.50(0.25)$ & $-0.45(0.46)$ \\
total S in soil & $0.21(0.04)$ & $\mathbf{- 0 . 9 3}(0.90)$ \\
C/N ratio in soil & $\mathbf{- 0 . 7 8}(0.60)$ & $-0.02(0.61)$ \\
plant-available P & $-0.62(0.39)$ & $\mathbf{- 0 . 5 2}(0.66)$ \\
mineral N & $\mathbf{- 0 . 8 4}(0.71)$ & $0.49(0.94)$ \\
$\sum$ Sand & $0.68(0.46)$ & $-0.25(0.52)$ \\
$\sum$ Silt & $\mathbf{- 0 . 8 3}(0.69)$ & $0.11(0.71)$ \\
$\sum$ Clay & $0.45(0.21)$ & $0.30(0.30)$ \\
H (Shannon-Wiener index) & $0.56(0.31)$ & $-0.22(0.36)$ \\
Flooding events & $0.40(0.16)$ & $\mathbf{- 0 . 8 8}(0.93)$ \\
\hline Given are the loadings of the selected variables along the four explanatory axes. Numbers in brackets behind the axis \\
indicate the eigenvalues (EV) of the axes. Numbers in bold mark the variables with closest correlation to the respective axis \\
(cumulative fit values are given in brackets). & &
\end{tabular}

\subsection{Discussion}

Our fine root inventory in three common salt marsh communities at two geomorphologically different salt marsh sites clearly showed differences in fine root mass between the three salt marsh communities across the elevational gradient, but also between the two sites. At both study sites, the greatest fine root mass was recorded in the lower salt marsh, which correlated with highest plant diversity in these communities, where Atriplex portulacoides co-existed with about 10 other herb and grass species. We assume that in this lower salt marsh community, a considerable diversity of below-ground space occupation strategies exists, as annuals (Salicornia spp.), small herbs (Spergularia media), tall herbs (e.g., Aster tripolium, Triglochin maritima), grasses (Puccinellia maritima, Spartina anglica, Festuca rubra) and dwarf shrubs (Atriplex portulacoides) share the rooted soil volume and likely partition 
space as explained by the "complementarity effect" (Loreau \& Hector, 2001). In contrast, the upper salt marsh community is nearly exclusively occupied by dense stands of Elytrigia atherica, and the pioneer zone is largely dominated by Spartina anglica with only low cover of additional grasses or herbs, which leaves less room for root space partitioning. This positive correlation between diversity and fine root mass in agreement with our hypothesis (iv) matches results from other root studies in salt marshes and other ecosystems and indicates an existing effect of biodiversity (Hooper et al., 2005; Cardinale et al., 2006). For example, Ford et al. (2016) found plant species richness to be a significant predictor of root biomass in a salt marsh in the UK. Similarly, in the mesocosm experiment of Sullivan et al. (2007) with various salt marsh species, a significant increase in root biomass and also in the root/shoot ratio was recorded with increasing species diversity. These different reports suggest that plant diversity is a driver of fine root mass in temperate salt marsh communities, in agreement with the findings in other non-saline grassland habitats (Mommer et al., 2010; Mueller et al., 2013; Eisenhauer et al., 2017; Weisser et al., 2017).

The lower salt marsh zone plays a crucial role for sediment trapping and stabilization in the foreland bordering dykes and islands along the north-west European Wadden Sea coast. Our root data suggest that the relatively species-rich communities with abundant A. portulacoides are effective sediment stabilisers, since plant diversity was found to increase root density. This matches the observation that plant species richness enhances soil stability and erosion protection in salt marshes and other grasslands (Coops et al., 1996; Chen et al., 2012; Gould et al., 2016). Supporting previous studies (Chen et al., 2012), we suggest that A. portulacoides plays a role as key species in stabilizing sediment by its extensive root system in ungrazed salt marsh sites.

The multiple regression analysis and the direct comparison of the three community types (zones) and two sediment types (sites) suggest that the principal abiotic factors salinity and inundation frequency only have a relatively small influence on fine root mass. The Na content of the sediment as a proxy of inundation duration showed a positive (though relatively weak) influence on root mass in the total sample (and in Westerhever), and root mass and root density reached a minimum in the upper marsh of both sites, where the exposure to salinity and inundation was lowest. This pattern is best explained by a dominant effect of plant 
species identity and species richness on community fine root mass, while effects of salinity (and anoxia) are diminished by effective adaptation of the species. It appears that productive species like S. anglica and A. portulacoides with specific adaptations to salinity and anoxia replace less adapted species in the lower marsh and pioneer zone, where they are capable of establishing large root systems. The photosynthesis of the C4 grass Spartina is rarely limited by salinity (Longstreth \& Strain, 1977) and the species is capable of oxidizing sulfide in the roots and rhizosphere by means of effective $\mathrm{O}_{2}$ transport to the sediment through its aerenchyma (Lee, 1999, 2003; Maricle \& Lee, 2002). Therefore, S. anglica is a highly productive species (exceeding 6,000 g d.m. $\mathrm{m}^{-2} \mathrm{yr}^{-1}$; Long \&Woolhouse, 1979) despite the mostly anoxic sediment. A. portulacoides is also highly tolerant of salinity (Redondo-Gómez et al., 2007) which is due to the accumulation of quaternary ammonium compounds for osmoregulation (Stewart \& Lee, 1974; Rozema et al., 1985). The effective adaptation of the pioneer zone species (and also of the lower marsh zone taxa) to the adverse conditions in this environment is also reflected in a higher proportion of root mass (31-35\%) in the subsoil (20-40 cm depth) of the pioneer zone compared to the upper salt marsh (1719\%). This is in accordance with our hypothesis (ii) in which we postulated a deeper root system in the more frequently inundated pioneer zone with well-adapted species. Interestingly, there was a great difference in fine root density between sites at $10 \mathrm{~cm}$ soil depth (Figure 5.4). It may be speculated that the very high fine root density in this soil depth found at Spiekeroog is related to the soil texture and associated lower plant-available $\mathrm{P}$ concentrations in the soil which may lead to a species-specific increase in fine root mass to compensate for limited $\mathrm{P}$ in the lower salt marsh. An earlier study by Strieckmann (1989, unpubl. data; Supplementary Material S5.4) also found no root density decrease down to $24 \mathrm{~cm}$ depth in other north German S. Anglica marshes. In contrast, the fine root density decrease from the topsoil to 20-40 cm was significant in the upper salt marsh of both sites, indicating that E. atherica is more sensitive to waterlogging (Armstrong et al., 1985; Schröder et al., 2002; Veeneklaas et al., 2013) and thus develops a shallower distribution of fine roots.

Our data also suggest that higher nutrient availability tends to reduce fine root mass, as it was postulated in our first hypothesis. Fine root mass was higher by roughly $25 \%$, and root area index even by about $50 \%$ in the sandy Spiekeroog plots 
compared to the silt- and clay-rich Westerhever plots. This may indicate that the plants in the sandy sediment need to produce larger root systems, with especially large surface area, to compensate for the generally lower concentrations of plantavailable nutrients found in the sandy sediments of the Spiekeroog salt marsh. Sediment stability might also be responsible for differences in fine root mass: a higher root mass in the sandy Spiekeroog sediments could be required for plant anchorage, as fine-grained clay soils resist erosion better than sandy soils (van Eerdt, 1985; Allen, 1989). Since bulk density was higher at the sandy Spiekeroog site providing less air and water space, and less space for root proliferation, especially in the deeper soil horizon, it may be assumed that the need of fine roots for nutrient capture and plant stability exceeds the disadvantages for root growth in soil with higher bulk density, furthermore indicating the good adaptation of roots to the abiotic conditions.

Comparison of our fine root mass data to other studies on below-ground biomass in salt marshes is limited due to several reasons. First, it has to be kept in mind that we measured total fine root mass and not fine root biomass, even though our figures should be close to biomass according to our live/dead ratio assessment under the microscope in a number of subsamples. While a few authors explicitly sampled only fine root biomass, various studies do not state, whether live and dead roots were separated, and the term "biomass" is sometimes used for total root mass (biomass + necromass), which makes comparison to other studies difficult. Second, other authors used different criteria for defining root mass or biomass, sometimes including coarse roots and rhizomes as well, or retrieving root mass with sieves of greater mesh size than we did. This will increase or decrease root biomass figures, thus leading to deviating results. Groenendijk and Vinklievaart (1987) investigated total below-ground biomass in $0-60 \mathrm{~cm}$ in a Dutch salt marsh and obtained much higher profile totals than we did, which may only be partly explained by the lower profile depth investigated in our study $(0-40 \mathrm{~cm})$. Nevertheless, the same root mass distribution patterns along the salt marsh elevational gradient became visible in the Dutch study: Greatest below-ground biomass totals were recorded in the $A$. portulacoides-dominated lower marsh (mean: 13,338 $\mathrm{g} \mathrm{m}^{-2}$ ), while the lowest biomass occurred in the upper marsh dominated by E. atherica (mean: 7,763 $\mathrm{g} \mathrm{m}^{-2}$ ). Comparison of our data from the S. anglica stands at our study sites (site means of 
Table 5.6 Compilation of root mass and aboveground biomass data from North Sea salt marshes up to a sediment depth of $20 \mathrm{~cm}$ from this study and for two further sites investigated by Strieckmann (1989).

\begin{tabular}{|c|c|c|c|c|c|}
\hline Study site & $\begin{array}{c}\text { Dominant } \\
\text { plant species }\end{array}$ & $\begin{array}{l}\text { Root mass } \\
\quad\left(\mathrm{g} \mathrm{m}^{-2}\right)\end{array}$ & $\begin{array}{c}\text { Aboveground } \\
\text { biomass } \\
\left(\mathrm{g} \mathrm{m}^{-2}\right) \\
\end{array}$ & Methodology & References \\
\hline \multirow{3}{*}{$\begin{array}{l}\text { Spiekeroog, } \\
\text { Germany } \\
\text { (ungrazed } \\
\text { marsh) }\end{array}$} & $\begin{array}{l}\text { Spartina } \\
\text { anglica }\end{array}$ & $1503 \pm 331$ & $1048 \pm 205$ & \multirow{6}{*}{$\begin{array}{l}\text { Size of sieve } \\
\text { for root } \\
\text { washing: } \\
200 \mu \mathrm{m} ; \\
\text { Soil depth: } \\
20 \mathrm{~cm} ; \\
\text { only fine roots } \\
\text { (dead and } \\
\text { alive); } \\
\text { sampling in } \\
\text { September; } \\
\text { mean } \pm \text { se } \\
\text { presented }\end{array}$} & \multirow{6}{*}{ This study } \\
\hline & $\begin{array}{c}\text { Atriplex } \\
\text { portulacoides }\end{array}$ & $2243 \pm 484$ & $712 \pm 210$ & & \\
\hline & $\begin{array}{l}\text { Elytrigia } \\
\text { atherica }\end{array}$ & $1296 \pm 111$ & $481 \pm 37$ & & \\
\hline \multirow{3}{*}{$\begin{array}{l}\text { Westerhever, } \\
\text { Germany } \\
\text { (ungrazed } \\
\text { marsh) }\end{array}$} & $\begin{array}{c}\text { Spartina } \\
\text { anglica }\end{array}$ & $888 \pm 123$ & $1134 \pm 159$ & & \\
\hline & $\begin{array}{c}\text { Atriplex } \\
\text { portulacoides }\end{array}$ & $1469 \pm 332$ & $2376 \pm 329$ & & \\
\hline & $\begin{array}{l}\text { Elytrigia } \\
\text { atherica }\end{array}$ & $617 \pm 46$ & $1685 \pm 387$ & & \\
\hline \multirow{5}{*}{$\begin{array}{l}\text { Oland, } \\
\text { Germany } \\
\text { (ungrazed } \\
\text { marsh) }\end{array}$} & $\begin{array}{c}\text { Spartina } \\
\text { anglica }\end{array}$ & 2594 & $235 \pm 146$ & \multirow{8}{*}{$\begin{array}{c}\text { Size of sieve } \\
\text { for root } \\
\text { washing: } \\
315 \mu \mathrm{m} ; \\
\text { soil depth: } \\
24 \mathrm{~cm} ; \\
\text { no } \\
\text { differentiation } \\
\text { between root } \\
\text { fractions; } \\
\text { sampling in } \\
\text { June; } \\
\text { mean } \pm \text { sd } \\
\text { presented }\end{array}$} & \multirow{8}{*}{$\begin{array}{c}\text { Strieckmann } \\
\text { (1989), } \\
\text { unpublished } \\
\text { data }\end{array}$} \\
\hline & $\begin{array}{c}\text { Spartina } \\
\text { anglica }+ \text { Aster } \\
\text { tripolium }\end{array}$ & 5156 & $783 \pm 179$ & & \\
\hline & $\begin{array}{c}\text { Spartina } \\
\text { anglica }\end{array}$ & 3967 & $778 \pm 184$ & & \\
\hline & $\begin{array}{c}\text { Atriplex } \\
\text { portulacoides }\end{array}$ & 1661 & $1191 \pm 916$ & & \\
\hline & $\begin{array}{l}\text { Elytrigia } \\
\text { atherica }\end{array}$ & 1712 & $2178 \pm 281$ & & \\
\hline \multirow{3}{*}{$\begin{array}{l}\text { Sönke- } \\
\text { Nissen-Koog, } \\
\text { Germany } \\
\text { (grazed } \\
\text { marsh) }\end{array}$} & $\begin{array}{l}\text { Puccinellia } \\
\text { maritima }\end{array}$ & 3496 & $518 \pm 83$ & & \\
\hline & $\begin{array}{l}\text { Puccinellia } \\
\text { maritima }\end{array}$ & 2148 & $486 \pm 164$ & & \\
\hline & $\begin{array}{c}\text { Spartina } \\
\text { anglica }\end{array}$ & 2743 & $499 \pm 171$ & & \\
\hline
\end{tabular}

1,500-2,000 $\mathrm{g} \mathrm{m}^{-2}$ ) with data from Spartina alterniflora-dominated salt marshes on the east coast of the United States indicates a similar root biomass average, but larger variation among sites (600-11,000 $\mathrm{g} \mathrm{m}^{-2}$; Smith et al., 1979; Windham et al., 2003; Tripathee \& Schaefer, 2015). Unpublished root biomass data from a grazed and an ungrazed salt marsh in Schleswig-Holstein (Germany) of Strieckmann (1989, unpublished) range between 1,000 and 5,000 $\mathrm{g} \mathrm{m}^{-2}$ for the profile to $24 \mathrm{~cm}$ (Table 5.6, Supplementary Material S5.4). In contrast to our study, the greatest belowground biomass in the ungrazed site was recorded in the plots dominated by $S$. anglica and $A$. tripolium, while the minimum $\left(\sim 1,500 \mathrm{~g} \mathrm{~m}^{-2}\right)$ occurred in the $A$. portulacoides stands. Similar to our plots in Westerhever, the upper salt marsh community with E. atherica dominance was the only stand with a root biomass/aboveground biomass ratio $<1$ (Table 5.6). 
The fact that we considered only fine roots ( $<2 \mathrm{~mm}$ in diameter) and not coarse roots and rhizomes, may explain differences in root biomass totals among different studies in Spartina marshes. For example, Darby and Turner (2008) found a mean root biomass of $753 \mathrm{~g} \mathrm{~m}^{-2}$, but a mean rhizome biomass of $1,952 \mathrm{~g} \mathrm{~m}^{-2}$ of S. alterniflora in a Louisiana salt marsh, matching findings of Schubauer and Hopkinson (1984). Data of total belowground biomass (including larger root diameters) are important for carbon cycle studies, but less informative when the below-ground absorptive surface of plants and communities is assessed. Several studies indicate that the standing fine root biomass (or mass) in salt marshes varies considerably with season (Groenendijk \& Vinklievaart, 1987; Steinke et al., 1996; Darby \& Turner, 2008), which may also explain differences between studies.

In our study, we did not distinguish between dead and live fine roots, as we found the proportion of dead fine roots to be low $(<10 \%)$ in all inspected samples. Similar live/dead ratios were reported by Groenendijk and Vinklievaart (1987) in a Dutch salt marsh ( $<15 \%$ non-living roots), while the proportion of below-ground necromass was greater in certain North American salt marshes, exceeding root biomass (Valiela et al., 1976; Schubauer \& Hopkinson, 1984; Darby \& Turner, 2008). Apart from differences in the root diameter considered and likely variance in root mortality rates, this may be a consequence of slow root decomposition rates as was found in a Dutch salt marsh (Buth, 1987). Direct observation of fine root dynamics with rhizoscopes may be needed to unravel the causes of different root live/dead ratios in anoxic sediments.

A comparison of the fine root mass of salt marshes with that of other grassland or herbaceous communities indicates that the multi-stress conditions in this saline environment demand for high carbohydrate investment in below-ground organs by the plants. According to root mass data compiled by Leuschner and Ellenberg (2017), non-saline mesic to moist temperate grasslands have root masses in the topsoil (mostly 0-15 cm) of 500-2,000 $\mathrm{g} \mathrm{m}^{-2}$ matching the root mass figures of our upper salt marsh, while being smaller than the root masses found in the lower marsh and the pioneer zone. Jackson et al. (1997) give a global fine root mass mean of $1,510 \mathrm{~g} \mathrm{~m}^{-2}$ for temperate grasslands, which is also lower than the root masses found in our lower salt marsh and in other Spartina stands in the northern hemisphere. Similarly, our root surface area totals (RAI values $>300 \mathrm{~m}^{2} \mathrm{~m}^{-2}$ ) were several times 
larger than the mean RAI recorded for temperate grasslands by Jackson et al. (1997) $\left(79.1 \mathrm{~m}^{2} \mathrm{~m}^{-2}\right)$.

One might expect that the substantial variation in inundation frequency, sediment anoxia and salinity found in the different salt marsh zones of Spiekeroog and Westerhever should lead to pronounced differences in fine root morphology in the different communities (hypothesis iii). Bouma et al. (2002) hypothesized that the salt marsh plants of the pioneer zone have slower-growing, more stress-tolerant roots, while the plants of the upper salt marsh should be faster growing, which might result in a higher RTD of the former. We found elevated tissue densities in both the upper marsh and the pioneer zone of the Westerhever site, but no difference across the Spiekeroog gradient and thus no consistent RTD pattern in our study. Similarly, community differences in SRL and SRA were not consistent across the two elevational gradients; mean fine root diameter was remarkably constant in our samples. We conclude from these inconsistent patterns that fine root morphology is largely under the control of plant species and their specific adaptations to the adverse conditions (i.e., the formation of aerenchyma), while a more general pattern of root morphology did not emerge in the studied salt marsh communities. This contradicts hypothesis (iii) but matches the findings of Bouma et al. (2001, 2002) of an only weak responsiveness of the root architecture of three halophytic grass species to nitrogen supply, inundation and oxygen content of the sediment and no relationship between root longevity and tissue density. Root $\mathrm{N}$ concentration peaked at both sites in the lower salt marsh, possibly reflecting species-specific $\mathrm{N}$ uptake patterns.

\subsection{Conclusions}

Our study in two salt marshes with contrasting geomorphology shows that fine root mass is relatively high and fine root surface area large in comparison to grassland ecosystems in terrestrial habitats. The plants of the frequently inundated lower marsh and pioneer zone seem to be well adapted to this stressful environment, allowing some specialist species such as Spartina to establish a root system with deep penetration of the sediment for good anchorage and nutrient supply. These adaptations of characteristic species appear to control the fine root mass of the salt marsh communities, overriding effects of environmental stress. As in other habitats 
with extreme environmental conditions, a higher number of plant species tends to increase root biomass and seems to promote soil exploration through root space partitioning by functionally different species. Studies on fine root dynamics and root function in terms of water and nutrient uptake are needed for a mechanistic understanding of the below-ground compartment of salt marsh communities and its sensitivity to environmental change.

\section{Acknowledgements}

We would like to thank the administrations of the Lower Saxony and SchleswigHolstein Wadden Sea National Parks for giving permission for study and allowing access to the field sampling sites. Special thanks go to Dr. Martin Stock for giving an on-site introduction in Westerhever and providing various data. Many thanks also to Till Montag for help with processing of the fine root samples and to Daniela Meier for providing data on water levels at Spiekeroog. Tide gauge data for Westerhever were provided by the Schleswig-Holstein Agency for Coastal Protection, National Park and Marine Conservation (Husum). 


\section{References}

Allen, J. R. (1989). Evolution of salt-marsh cliffs in muddy and sandy systems: a qualitative comparison of British west-coast estuaries. Earth Surface Processes and Landforms, 14(1), 85-92.

Armstrong, W., Wright, E. J., Lythe, S., \& Gaynard, T. J. (1985). Plant zonation and the effects of the spring-neap tidal cycle on soil aeration in a humber salt-marsh. Journal of Ecology, 73, 323-339.

Bakker, J. P. (2014). Ecology of Salt Marshes: 40 Years of Research in the WaddenSea. Leeuwarden: Wadden Academy.

Bouchard, V., \& Lefeuvre, J. C. (2000). Primary production and macro-detritus dynamics in a European salt marsh: carbon and nitrogen budgets. Aquatic Botany, 67, 23-42.

Bouma, T. J., Hengst, K., Koutstaal, B. P., \& van Soelen, J. (2002). Estimating root lifespan of two grasses at contrasting elevation in a salt marsh by applying vitality staining on roots from in-growth cores. Plant Ecology, 165, 235-245.

Bouma, T. J., Koutstaal, B. P., van Dongen, M., \& Nielsen, K. L. (2001). Coping with low nutrient availability and inundation: root growth responses of three halophytic grass species from different elevations along a flooding gradient. Oecologia, 126, 472-481.

Buth, G. J. (1987). Decomposition of roots of three plant communities in a Dutch salt marsh. Aquatic Botany, 29, 123-138.

Cardinale, B. J., Srivastava, D. S., Duffy, J. E., Wright, J. P., Downing, A. L., Sankaran, M., \& Jouseau, C. (2006). Effects of biodiversity on the functioning of trophic groups and ecosystems. Nature, 443, 989-992.

Cardinale, B. J., Wright, J. P., Cadotte, M. W., Carroll, I. T., Hector, A., Srivastava, D. S., Loreau, M., \& Weis, J. J. (2007). Impacts of plant diversity on biomass production increase through time because of species complementarity. PNAS, $104,18123-18128$

Chen, Y., Thompson, C. E. L., \& Collins, M. B. (2012). Salt marsh creek bank stability: biostabilisation and consolidation with depth. Continental Shelf Research, 35, 64-74.

Cooper, A. (1982). The effects of salinity and waterlogging on the growth and cation uptake of salt marsh plants. New Phytologist, 90, 263-275. 
Coops, H., Geilen, N., Verheij, H. J., Boeters, R., \& van der Velde, G. (1996). Interactions between waves, bank erosion and emergent vegetation: an experimental study in a wave tank. Aquatic Botany, 53, 187-198.

Darby, F. A., \& Turner, R. E. (2008). Below- and aboveground Spartina alterniflora production in a Louisiana salt marsh. Estuaries Coast, 31, 223-231.

Eisenhauer, N., Lanoue, A., Strecker, T., Scheu, S., Steinauer, K., Thakur, M. P., \& Mommer, L. (2017). Root biomass and exudates link plant diversity with soil bacterial and fungal biomass. Scientific Reports, 7, 44641.

Ford, H., Garbutt, A., Ladd, C., Malarkey, J., \& Skov, M. W. (2016). Soil stabilization linked to plant diversity and environmental context in coastal wetlands. Journal of Vegetation Science, 27, 259-268.

Gill, R. A., \& Jackson, R. B. (2000). Global patterns of root turnover for terrestrial ecosystems. New Phytologist, 147, 13-31.

Gould, I. J., Quinton, J. N., Weigelt, A., De Deyn, G. B., \& Bardgett, R. D. (2016). Plant diversity and root traits benefit physical properties key to soil function in grasslands. Ecology Letters, 19, 1140-1149.

Groenendijk, A. M., \& Vinklievaart, M. A. (1987). Primary production and biomass on a Dutch salt-marsh - emphasis on the belowground component. Vegetatio, 70, 21-27.

Heinrichs, H., Brumsack, H. J., Loftfield, N., \& König, N. (1986). Verbessertes Druckaufschlußsystem für biologische und anorganische Materialien. Zeitschrift für Pflanzenernährung und Bodenkunde, 149, 350-353.

Hertel, D., \& Leuschner, C. (2002). A comparison of four different fine root production estimates with ecosystem carbon balance data in a Fagus-Quercus mixed forest. Plant and Soil, 239, 237-251.

Hooper, D. U., Chapin, F. S., Ewel, J. J., Hector, A., Inchausti, P., Lavorel, S., Lawton, J. H., Lodge, D. M., Loreau, M., Naeem, S., Schmid, B., Setälä, H., Symstad, A. J., Vandermeer, J., \& Wardle, D. A. (2005). Effects of biodiversity on ecosystem functioning: a consensus of current knowledge. Ecological Monographs, 75, 335.

Jackson, R. B., Canadell, J., Ehleringer, J. R., Mooney, H. A., Sala, O. E., \& Schulze, E. D. (1996). A global analysis of root distributions for terrestrial biomes. Oecologia, $108,389-411$. 
Jackson, R. B., Mooney, H. A., \& Schulze, E.-D. (1997). A global budget for fine root biomass, surface area, and nutrient contents. PNAS, 94, 7362-7366.

Kiehl, K., Esselink, P., \& Bakker, J. P. (1997). Nutrient limitation and plant species composition in temperate salt marshes. Oecologia, 111, 325.

Lee, R. W. (1999). Oxidation of sulfide by Spartina alterniflora roots. Limnology Oceanography, 44, 1155-1159.

Lee, R. W. (2003). Physiological adaptations of the invasive cordgrass Spartina anglica to reducing sediments: rhizome metabolic gas fluxes and enhanced $\mathrm{O}_{2}$ and $\mathrm{H}_{2} \mathrm{~S}$ transport. Marine Biology, 143, 9-15.

Leuschner, C., \& Ellenberg, H. (2017). Ecology of Central European Non- Forest Vegetation: Coastal to Alpine, Natural to Man-Made Habitats: Vegetation Ecology of Central Europe Volume II. Chapter 1: Salt Marshes and Inland Saline Habitats. Cham: Springer.

Leuschner, C., Gebel, S., \& Rose, L. (2013). Root trait responses of six temperate grassland species to intensive mowing and NPK fertilisation: a field study in a temperate grassland. Plant and Soil, 373, 687-698.

Levine, J. M., Brewer, J. S., \& Bertness, M. D. (1998). Nutrients, competition and plant zonation in a New England salt marsh. Journal of Ecology, 86, 285-292.

Long, S. P., \& Woolhouse, H. W. (1979). Primary production in Spartina marshes. Ecological Processes in Coastal Environments, 333-352.

Longstreth, D. J., \& Strain, B. R. (1977). Effects of salinity and illumination on photosynthesis and water balance of Spartina alterniflora Loisel. Oecologia, 31, 191-199.

Loreau, M., \& Hector, A. (2001). Partitioning selection and complementarity in biodiversity experiments. Nature, 412, 72-76.

Maricle, B. R., \& Lee, R. W. (2002). Aerenchyma development and oxygen transport in the estuarine cordgrasses Spartina alterniflora and S. anglica. Aquatic Botany, $74,109-120$.

Mommer, L., van Ruijven, J., Caluwe, H., de Smit-Tiekstra, A. E., Wagemaker, C. A. M., Ouborg, N. J., Bögemann, G. M., van der Weerden, G. M., Berendse, F., \& de Kroon, H. (2010). Unveiling below-ground species abundance in a biodiversity experiment: a test of vertical niche differentiation among grassland species. Journal of Ecology, 98, 1117-1127. 
Mueller, K. E., Tilman, D., Fornara, D. A., \& Hobbie, S. E. (2013). Root depth distribution and the diversity-productivity relationship in a long-term grassland experiment. Ecology, 94, 787-793.

Peiter, A. (2004). GIS-gestützte Auswertung von Monitoringdaten am Beispiel einer Habitatanalyse für Nonnengänse (Branta leucopsis) und Ringelgänse (Branta bernicla) in der Salzwiese Westerhever. Diploma thesis, University of Vechta.

R Development Core Team (2016). R: A Language and Environment for Statistical Computing. Vienna: R Foundation for Statistical Computing. Available online at: https://www.R-project.org/

Redondo-Gómez, S., Mateos-Naranjo, E., Davy, A. J., Fernández-Muñoz, F., Castellanos, E. M., Luque, T., \& Figueroa, M. E. (2007). Growth and photosynthetic responses to salinity of the salt-marsh shrub Atriplex portulacoides. Annals of Botany, 100, 555-563.

Rozema, J., Bijwaard, P., Prast, G., \& Broekman, R. (1985). Ecophysiological adaptations of coastal halophytes from foredunes and salt marshes. Vegetatio, $62,499-521$.

Rozema, J., Gude, H., \& Pollak, G. (1981). An ecophysiological study of the salt secretion of 4 halophytes. New Phytologist, 89, 201-217.

Schröder, H. K., Kiehl, K., \& Stock, M. (2002). Directional and non- directional vegetation changes in a temperate salt marsh in relation to biotic and abiotic factors. Applied Vegetation Science, 5, 33-44.

Schubauer, J. P., \& Hopkinson, C. S. (1984). Above- and belowground emergent macrophyte production and turnover in a coastal marsh ecosystem, Georgia. Limnology Oceanography, 29, 1052-1065.

Schüller, H. (1969). Die CAL-Methode, eine neue Methode zur Bestimmung des pflanzenverfügbaren Phosphates in Böden. Zeitschrift für Pflanzenernährung und Bodenkunde, 123, 48-63.

Smith, K. K., Good, R. E., \& Good, N. F. (1979). Production dynamics for above and belowground components of a New Jersey Spartina alterniflora tidal marsh. Estuarine Coast. Estuarine and Coastal Marine Science, 9, 189-201.

Steinke, W., von Willert, D. J., \& Austenfeld, F. A. (1996). Root dynamics in a salt marsh over three consecutive years. Plant and Soil, 185, 265-269. 
Steudel, B., Hautier, Y., Hector, A., \& Kessler, M. (2011). Diverse marsh plant communities are more consistently productive across a range of different environmental conditions through functional complementarity. Journal of. Applied Ecology, 48, 1117-1124.

Stewart, G. R., \& Lee, J. A. (1974). The role of proline accumulation in halophytes. Planta, 120, 279-289.

Stock, M. (2012). TMAP Wadden Sea Sedimentation Database: vegetation databases for the 21st century. Biodiversity and Ecology, 4, 372.

Stock, M., Gettner, M., Hagge, H., Heinzel, K., Kohlus, J., \& Stumpe, H. (2005). Salzwiesen an der Westküste von Schleswig-Holstein 1998 - 2001. Tönning: Schriftenreihe des Nationalparks Schleswig-Holsteinisches Wattenmeer.

Strieckmann, R. (1989). Pflanzliche Biomasse- und Nährstoffvorräte in verschiedenen Salzvegetationstypen. Diploma thesis, Georg-August-University Göttingen.

Sullivan, G., Callaway, J. C., \& Zedler, J. B. (2007). Plant assemblage composition explains and predicts how biodiversity affects salt marsh functioning. Ecology Monographs, 77, 569-590.

Tripathee, R., \& Schaefer, K. V. R. (2015). Above- and belowground biomass allocation in four dominant salt marsh species ofthe eastern United States. Wetlands, 35, 21-30.

Ungar, I. A. (1998). Are biotic factors significant in influencing the distribution of halophytes in saline habitats? The Botanical Review, 64, 176-199.

Valiela, I., \& Teal, J. M. (1974). Nutrient limitation in salt marsh vegetation. Ecology of Halophytes, 547-563.

Valiela, I., Teal, J. M., \& Persson, N. Y. (1976). Production and dynamics of experimentally enriched salt marsh vegetation: belowground biomass. Limnology Oceanography, 21, 245-252.

van Eerdt, M. M. (1985). The influence of erosion and accretion in salt marshes of the Oosterschelde, The Netherlands. Vegetatio, 62, 367-373.

van Wijnen, H. J., \& Bakker, J. P. (1999). Nitrogen and Phosphorus limitation in a coastal barrier salt marsh: the implications for vegetation succession. Journal of Ecology, 87, 265-272. 
Veeneklaas, R. M., Dijkema, K. S., Hecker, N., \& Bakker, J. P. (2013). Spatio-temporal dynamics of the invasive plant species Elytrigia atherica on natural salt marshes. Applied Vegetation Science, 16, 205-216.

Weisser, W. W., Roscher, C., Meyer, S. T., Ebeling, A., Luo, G., Allan, E., Beßler, H., Barnard, R. L., Buchmann, N., Buscot, F., Engels, C., Fischer, C., Fischer, M., Gessler, A., Gleixner, G., Halle, S., Hildebrandt, A., Hillebrand, H., de Kroon, H., Lange, M., Leimer, S., Le Roux, X., Milcu, A., Mommer, L., Niklaus, P., Oelman, Y., Proulx, R., Roy, J., Scherber, C., Scherer-Lorenzen, M., Scheu, S., Tscharntke, T., Wachendorf, M., Wagg, C., Weigelt, A., Wilcke, W., Wirth, C., Schulze, E.-D., Schmid, B., \& Eisenhauer, N. (2017). Biodiversity effects on ecosystem functioning in a 15-year grassland experiment: patterns, mechanisms, and open questions. Basic and Applied Ecology, 23, 1-73.

Windham, L., Weis, J. S., \& Weis, P. (2003). Uptake and distribution of metals in two dominant salt marsh macrophytes, Spartina alterniflora (cordgrass) and Phragmites australis (common reed). Estuarine, Coastal and Shelf Science, 56, 63-72. 
Supplementary material

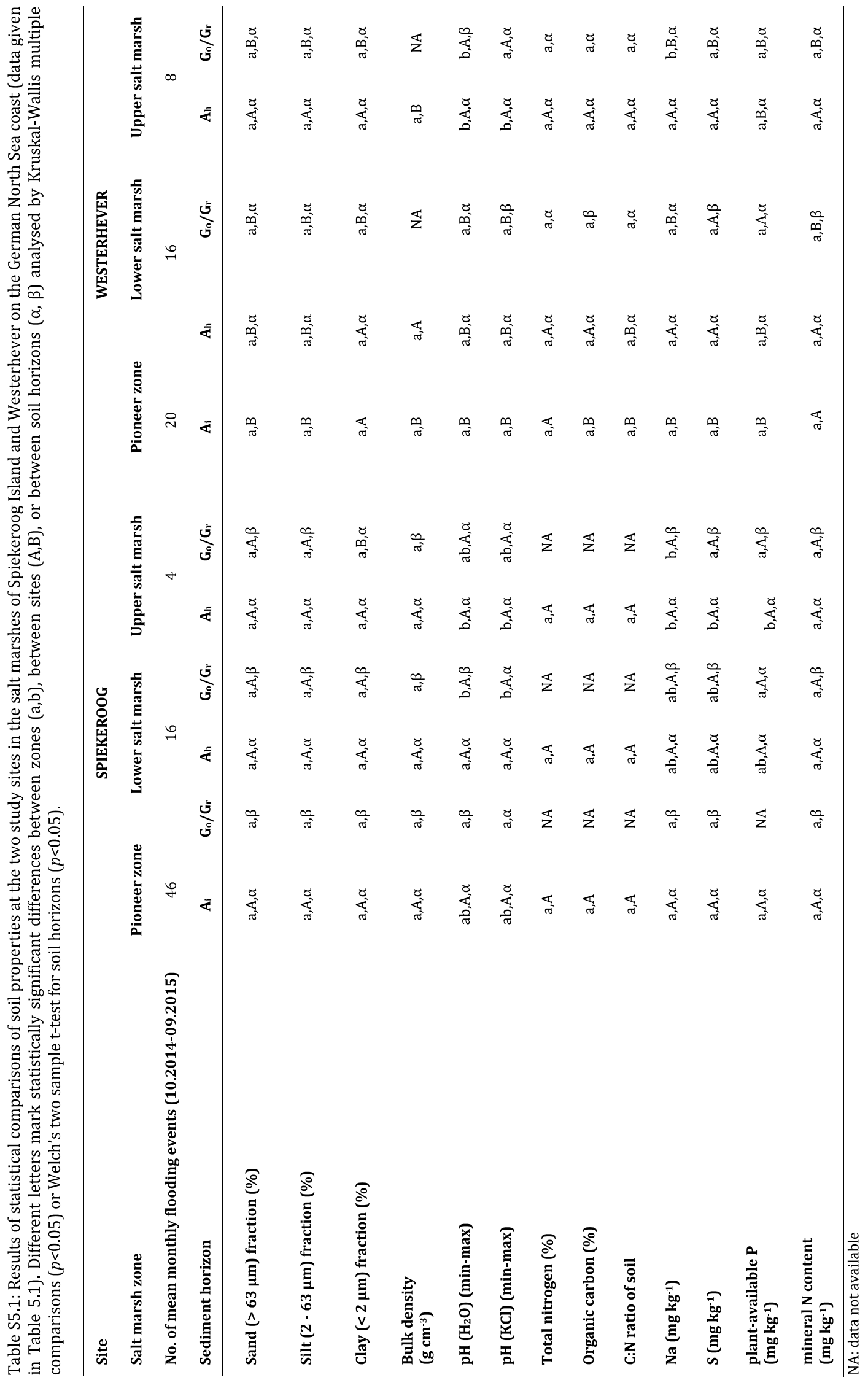




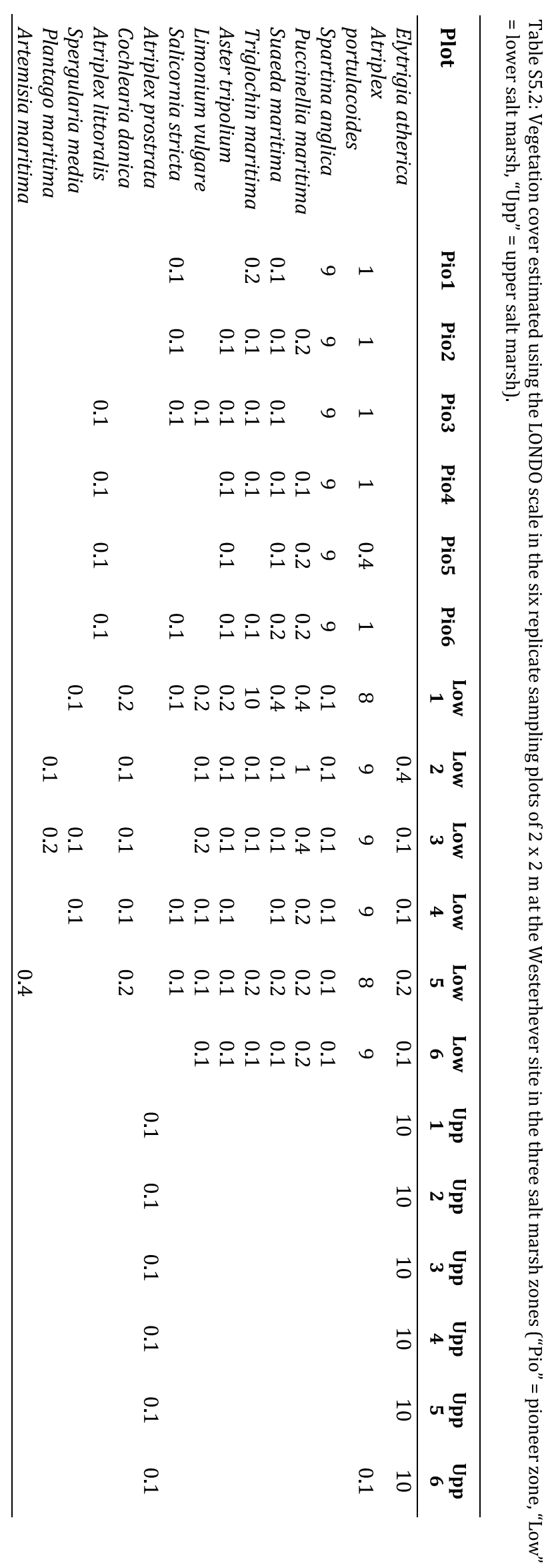




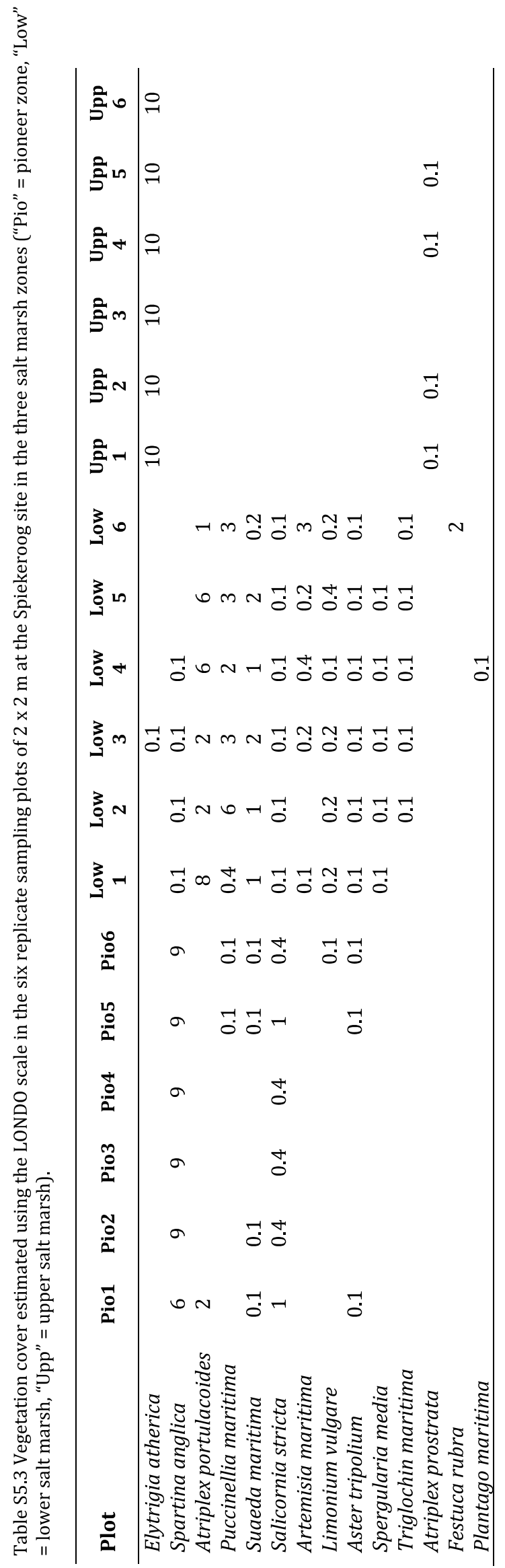




\section{Chapter 5}

Principle Components Analysis (PCA) for deeper soil

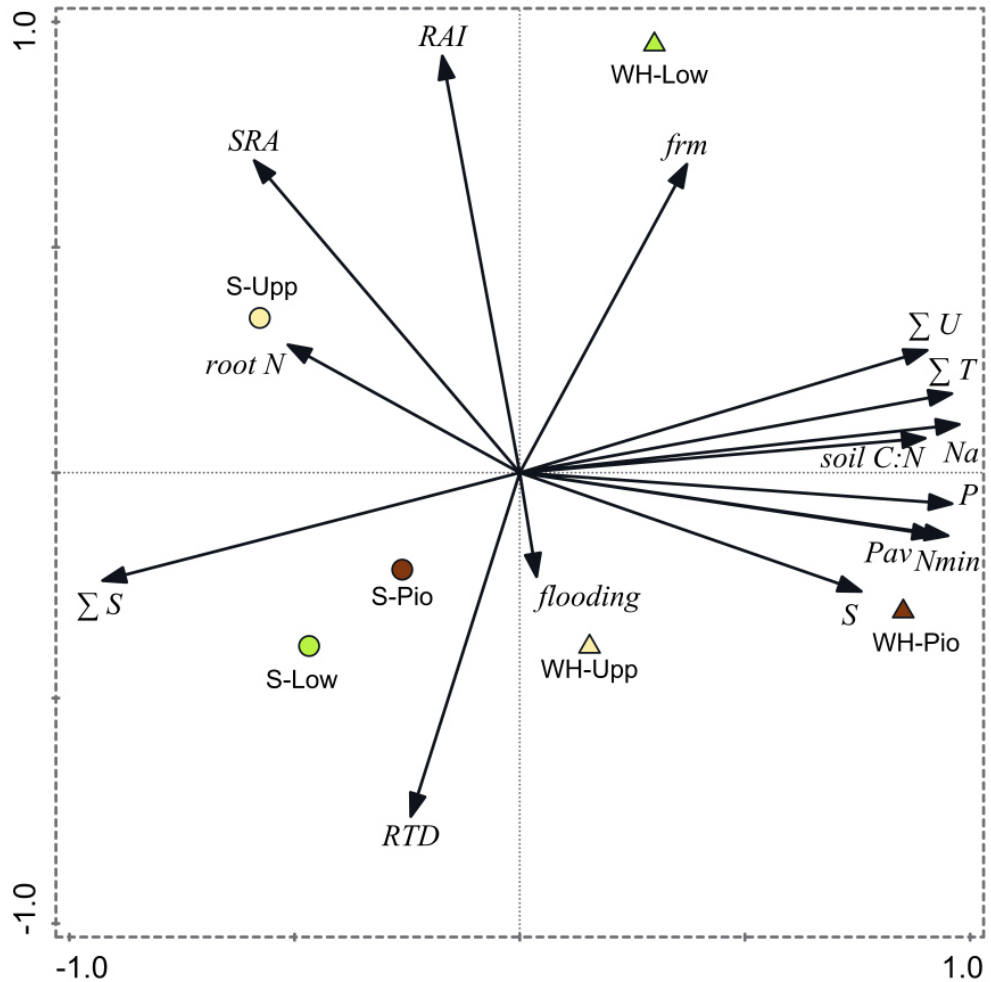

Figure S5.3 Plot showing the distribution of the three salt marsh zones (Pio, Low and Upp) in the two salt marsh sites Spiekeroog (S) and Westerhever (WH) in PCA axes 1 and 2 with soil and root properties (SRA: specific root area, $\sum$ T: clay fraction, RAI: root area index, FRM: fine root mass, root $\mathrm{N}$ : root $\mathrm{N}$ concentration, $\sum \mathrm{S}$ : sand fraction, $\mathrm{H}$ : Shannon-Wiener index, Na: Na concentration in soil, flooding: monthly flooding events, P: total P in soil, Pav: plant-available P in soil, RTD: root tissue density, $\sum \mathrm{U}$ : silt fraction, $\mathrm{Nmin}$ : mineral $\mathrm{N}\left(\mathrm{NO}_{3}{ }^{-}\right.$and $\left.\mathrm{NH}_{4}{ }^{+}\right)$in soil) related to the deeper soil horizon ( $\left.\mathrm{G}_{\mathrm{o}} / \mathrm{G}_{\mathrm{r}}\right)$. Vector length and angle are proportional to the direction and degree of their correlation with the plot ordination scores. 
Table S5.4 Results of a Principal Components Analysis (PCA) on the differentiation of the 3 salt marsh zones at both study sites with respect to fine root mass, root morphological traits, species diversity and soil properties of the Go/Gr horizon. Given are the loadings of the selected variables along the four explanatory axes. Numbers in brackets below the axes indicate the eigenvalues (EV) of the axes. Numbers in bold mark the variables with closest correlation to the respective axis (cumulative fit values are given in brackets).

\begin{tabular}{|c|c|c|c|}
\hline & $\begin{array}{c}\text { Axis 1 } \\
\text { (EV 0.5633) }\end{array}$ & $\begin{array}{c}\text { Axis 2 } \\
\text { (EV 0.1873) }\end{array}$ & $\begin{array}{c}\text { Axis 3 } \\
(\text { EV 0.1430) }\end{array}$ \\
\hline fine root mass & $0.38(0.14)$ & $0.78(0.61)$ & $0.55(0.91)$ \\
\hline specific root area & $-0.59(0.35)$ & $0.69(0.83)$ & $-0.30(0.92)$ \\
\hline root tissue density & $-0.24(0.06)$ & $-0.76(0.64)$ & $-0.28(0.72)$ \\
\hline $\begin{array}{ll}\text { root } & \mathrm{N} \\
\text { concentration } & \end{array}$ & $-0.51(0.26)$ & $0.28(0.35)$ & $-0.32(0.45)$ \\
\hline root surface area & $-0.17(0.03)$ & $0.92(0.88)$ & $0.24(0.94)$ \\
\hline total $\mathrm{Na}$ in soil & $0.98(0.95)$ & $0.11(0.96)$ & $0.05(0.97)$ \\
\hline total $P$ in soil & $0.96(0.92)$ & $-0.07(0.93)$ & $-0.10(0.94)$ \\
\hline total S in soil & $0.76(0.57)$ & $-0.26(0.64)$ & $0.59(0.99)$ \\
\hline $\mathrm{C} / \mathrm{N}$ ratio in soil & $0.90(0.81)$ & $0.08(0.82)$ & $-0.13(0.83)$ \\
\hline plant available $\mathrm{P}$ & $0.92(0.85)$ & $-0.14(0.87)$ & $-0.12(0.89)$ \\
\hline plant available $\mathrm{N}$ & $0.95(0.90)$ & $-0.14(0.92)$ & $-0.11(0.93)$ \\
\hline$\sum$ Sand & $-0.93(0.86)$ & $-0.24(0.92)$ & $0.25(0.97)$ \\
\hline$\sum$ Silt & $0.90(0.82)$ & $0.27(0.89)$ & $-0.27(0.96)$ \\
\hline $\bar{\sum}$ Clay & $0.96(0.92)$ & $0.18(0.95)$ & $-0.20(0.99)$ \\
\hline flooding & $0.04(0.00)$ & $-0.23(0.05)$ & $0.97(0.99)$ \\
\hline
\end{tabular}




\section{Chapter 5}
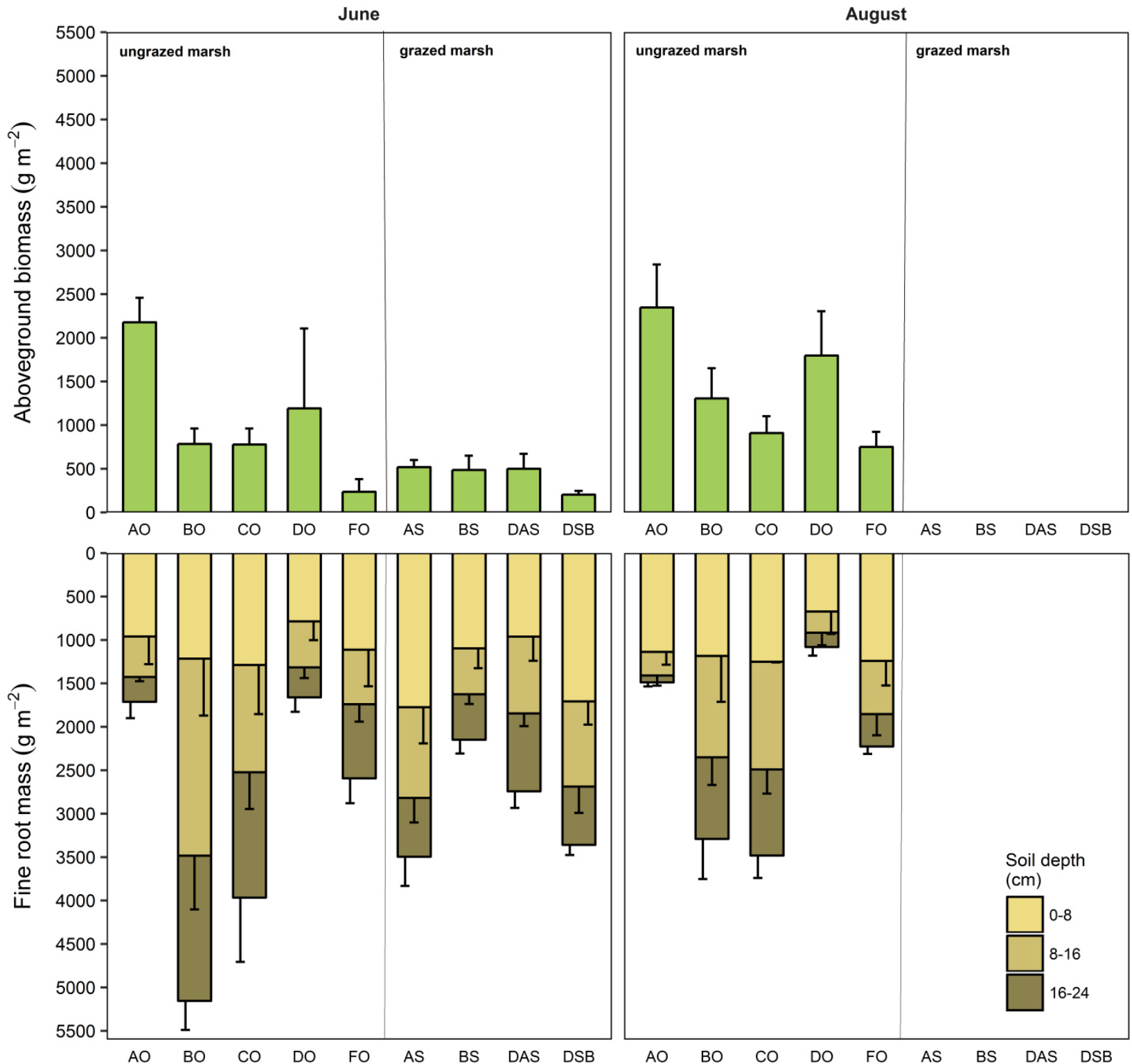

Figure S5.4 Above-ground vs. below-ground (fine root) biomass (dry weight) at nine plots in two salt marsh sites (means $\pm S D, n=4-6$ ). Plot names with an "O" are located in an ungrazed salt marsh on the Hallig island Oland, plot names with an "S" are located in a grazed salt marsh at Sönke-Nissen-Koog (both are located in SchlswigHolstein, Germany). The first letter of the plot name refers to the plant community: "A0": Elytrigia atherica dominated (Oland), "BO": Spartina anglica with Aster tripolium (Oland), "CO": Spartina anglica dominated Oland, "DO": Atriplex portulacoides dominated (Oland), "FO": Spartina anglica dominated Oland, "AS" Spartina anglica dominated (Sönke-Nissen-Koog), "BS": Puccinellia maritima dominated (Sönke-Nissen-Koog), "DAS”: Spartina anglica dominated at a scoured location (Sönke-Nissen-Koog), "DSB": Puccinellia maritima dominated on an elevated location (Sönke-Nissen-Koog). Data collected by Rita Strieckmann (1989, unpublished). 


\section{Chapter 6}

\section{General discussion}

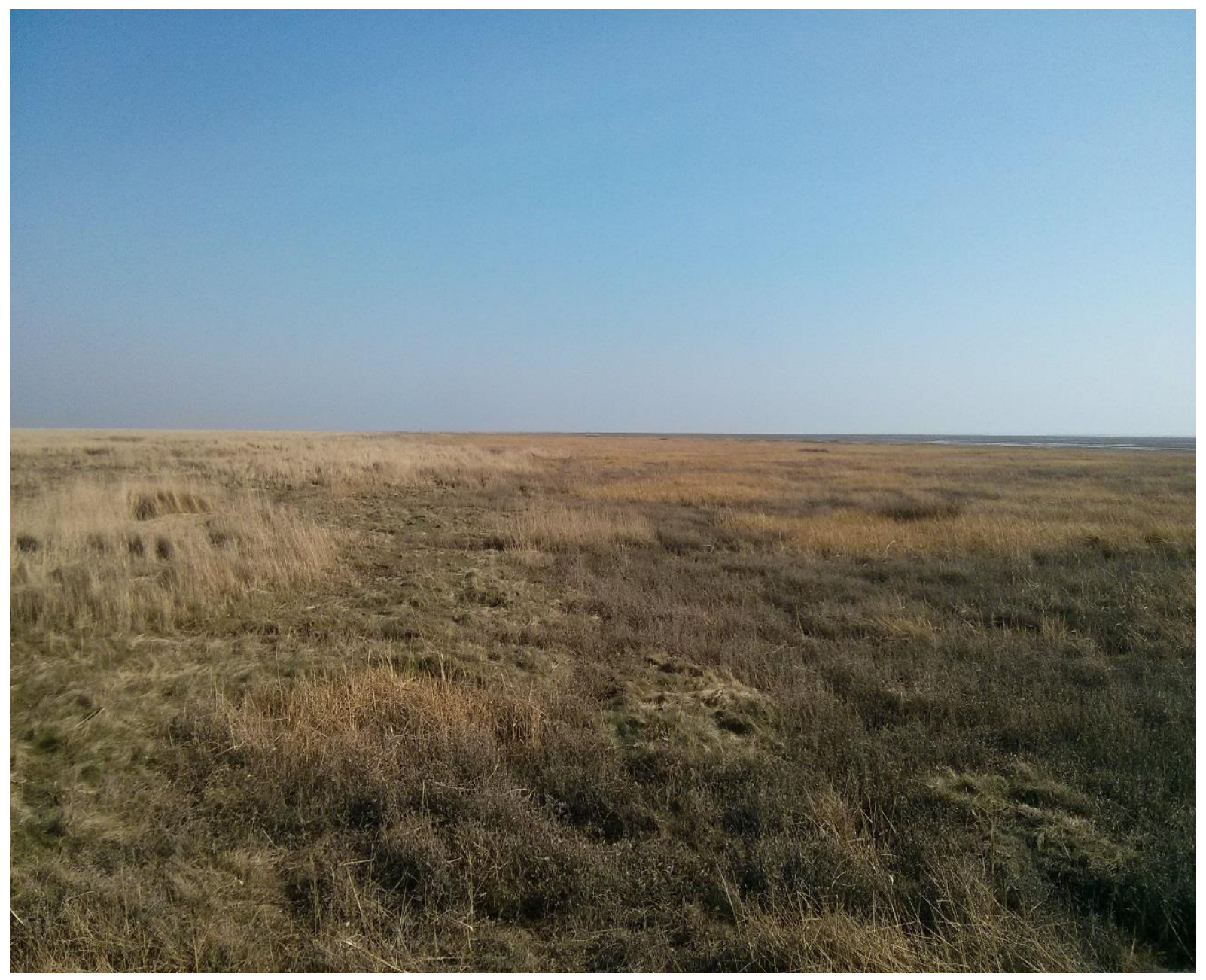


In this thesis, I investigated various biotic and abiotic soil parameters of salt marshes of the East Friesian island Spiekeroog. Salt marshes are habitats of extreme conditions with highly adapted fauna and flora. As this requires close linkage between the biosphere and the physical or chemical domain, even minor changes in either can result in severe consequences for the whole ecosystem. Direct manipulations and observation of specific traits of this exceptional system were topics in the chapters of my PhD thesis: In chapter 2, I manipulated the tidal influence on two different salt marsh soils and studied the response of $\mathrm{CO}_{2}$ efflux and changes in the microbial community. Regarding formerly introduced parameters, this means a direct manipulation of abiotic factors to monitor the response of biotic factors. Chapter 3 dealt with the decomposition of rapidly available substances in the salt marsh of Spiekeroog and the biotic (invertebrates) and abiotic (nutrients) responses. Similar efforts were expended in chapter 4 through the decomposition of homogeneous plant material under various climatic conditions in tidal wetlands around the world. In conclusion, chapter $\mathbf{3}$ and $\mathbf{4}$ were studies monitoring biotic parameters (decomposition) framed by natural abiotic factors (i.e. tidal amplitude, temperature, location). In chapter 5 we studied different root traits and in relation to sampling site and various soil parameters. Again, abiotic conditions served as explanatory factors for biotic parameters (root traits). Moreover, we could assess strategies of plants to cope with different abiotic conditions. In the following chapter, results of all studies will be coherently discussed and conclusions will be drawn with the aim to improve the understanding of this unique salt marsh ecosystem and its diverse reciprocal influential parameters.

Salt marshes are coastal areas with unique carbon sequestration, nutrient transformation and organic matter production capabilities (Barbier et al., 2011). These ecosystem functions (discussed in chapters 2, 3 and 4) together with physical sediment trapping by plants (chapter 5), are affected by and affect themselves abiotic parameters as introduced in chapter 1, with tidal inundation identified as the "prime- or master-parameter" for salt marsh ecosystems. Relating to my four chapters, results concerning these parameters will be discussed consecutively in the following and their impact on biotic factors will be highlighted. 


\subsection{Moisture and water level}

The most obvious consequences derived from enhanced tidal inundation might be a higher water table and moisture supply. In chapter 4 we found evidence that a higher sea level yields to a decreased soil organic matter (SOM) formation and therefore lower carbon (C) sequestration. Although the exact reasons for this are not yet known, it may be speculated that a more regular moisture supply induced by regular tidal inundation favours decomposition processes of organic matter (Halupa \& Howes, 1995). This result is in accordance with my findings in chapter 2, where temporal flooding in the "Tide" treatment promotes SOC turnover in a stronger manner even compared to "Ebb" treatments. Enhanced soil moisture therefore promotes higher microbial activity (Neckles \& Neill, 1994; Kirwan et al., 2013).

However, not only $\mathrm{C}$ sequestration and SOM decomposition are affected by rate of tidal inundation and moisture: A mechanism called "Priming Effect" (PE) as introduced in chapter 2, also depends on water supply: In chapter 2, I added labelled glucose to microcosms to trigger PE in an 24h "Ebb"-, "Flood"- and a "Tide"-simulated scenario. To a certain extent, PE contradicted $\mathrm{CO}_{2}$ efflux results with being higher under "Ebb" conditions compared to pure "Flood" or "Tide"-treatments. However, in this case, this can be connected to dilution effects of added glucose to induce PE and more stable conditions in the "Ebb" treatment and it might therefore be an experimental artefact. On the other hand, other authors support my findings of negligible PE in aquatic ecosystems: Catalán et al. (2015) suggested that in those systems, bacteria tend to incorporate labile carbon for growth and biomass rather than for production of extracellular enzymes to hydrolyse recalcitrant organic carbon sources.

Concerning the effect of regular inundation on plants and root traits, plants need to be thoroughly fixed within the sediment to maintain a stable position. This is expressed by a deeper root system in Pio, being regularly flooded, as compared to Low or Upp in chapter 5. However, the PCA results in chapter 5 indicate other factors being of higher importance governing characteristics of fine root mass (FRM) e.g. nutrient availability and soil matrix. 


\subsection{Salt and oxygen}

Changes in salinity and oxygen levels of the soil are secondary consequences to shifts in tidal inundation. In chapter 3 I found evidence for a certain conservation effect of salt water: The mass loss of a decomposing carcass was faster in higher elevated regions as compared to lower salt marsh elevations. Hemminga et al. (1991) verified experimentally that high concentrations of salt in marsh soils can limit decomposition in substantial amounts. But not only decomposition seems to be affected by salinity; PE also appears to be of minor importance for SOM turnover under flooded conditions (see chapter 2). This is caused indirectly by a generally lower microbial biomass in Pio compared to the more terrestrial salt marsh elevations such as Low. It can be hypothesised that in regions within the salt marsh which are often and regularly inundated, accumulation of high bacterial biomass is hampered due to disturbance effects (i.e. high salt concentrations) and an establishment of a "semi-equilibrium-state" with the surrounding water reduces possibilities for microorganisms to find niches with high cell densities ("Hot Spots"). The higher PE in Low, where inundation is less pronounced compared to Pio, is then induced by a higher chance of cometabolic effects (Fontaine et al., 2003): Different microorganisms are specialised for different parts of SOM which in turn leads to a generally higher PE potential with a higher microbial biomass.

A lack of oxygen in the soil is another factor which can negatively affect decomposition rate in systems with regular stable water tables. Constantly flooded soils show reduced gas diffusion resulting in a lower $\mathrm{CO}_{2}$-efflux rate (chapter 2). Being forced to use alternate electron acceptors under anaerobic conditions, cumulative gas diffusion is lower due to a slower metabolism (Burdige, 1991; Nyman et al., 2006; Langley et al., 2009). Furthermore, anaerobic conditions can diminish PE to negligible levels, as reported in chapter 2. In accordance with Canfield (1994) and Kristensen et al. (1995), I ascribe this to a lower capability to hydrolyse large, complex molecules typical for recalcitrant SOM when the soil is in an anoxic state most of the time, although this is not an exclusive factor. Therefore, even when initial energy is supported by a rather labile added substrate, no substantial amount of additional SOM is being decomposed. In addition, different metabolic pathways under anaerobic conditions compared to oxygen respiration have to be considered: 
in chapter $2 \mathrm{PE}$ was measured by trapping $\mathrm{CO}_{2}$ in $\mathrm{NaOH}$. However, under anaerobic conditions, a high proportion of $\mathrm{C}$ might be respired as methane $\left(\mathrm{CH}_{4}\right)$ which was not trapped by the alkaline solution used in my experiment (Ponnamperuma, 1972; Bartlett \& Harriss, 1993) leading to a smaller PE than expected.

Considering all the mentioned restrictions, my studies indicated clear adaptation capabilities of biota to salinity and anoxic conditions within the salt marsh soil. In chapter 4, decomposition of tea bags distributed among wetlands in various latitudes was neither affected by sea level nor by lower oxygen availability. The lack of a clear decline in decomposition rate with increasing soil salinity and anoxia represents a strong evidence for niche adaptation and high resilience within the local bacterial community (chapter 2): Denitrifying bacteria can cope with fast changing redox conditions even under hypoxic conditions (Beck, 2012). Another example are sulphate reducers (e.g. Desulfovibio halophilus or Desulphohalobium retbaense) maintaining high cytoplasmatic $\mathrm{KCl}$ concentrations to neglect osmotic differences with the surrounding medium (Caumette et al., 1991; Ollivier et al., 1994; Zahran, 1997). Regarding plants and their distribution within the salt marsh system, it is obvious that salt and the anaerobic state of the soil prohibit ordinally terrestrial plants from settling in elevations below mean high tide (MHT). However, by analysing FRM traits we could verify that specialists adapt to fast changing salt contents and oxygen levels of the soil (chapter 5). Many strategies have evolved, such as salt excretion through salt glands or oxygenation of the rhizosphere as protection against toxic reduced compounds (Bakker, 2014; Koop-Jakobsen \& Wenzhöfer, 2015). Another mechanism performed by Triglochin maritima involves accumulation of free L-proline to up to $20 \%$ of its dry mass to compensate osmotic stress in the vacuoles (Steward \& Lee, 1974).

Overall, salt stress and anoxia are important factors shaping the salt marsh ecosystem on a commanding level. Nevertheless, in accordance with other studies (Hackney, 1987; Kirwan et al., 2013; Blum \& Christian, 2004; Mueller et al., 2016) I could show that remarkable adaptations of salt marsh fauna and flora enable them to maintain in an environment not habitable for other species. 


\subsection{Nutrients and the priming effect}

To keep pace with the sea level rise, salt marshes gain elevation i.a. through the balance between OM sequestration and decomposition (Kirwan \& Megonigal, 2013). In chapter 4, we found evidence that coastal eutrophication has a negative impact on $\mathrm{C}$ storage, at least in higher salt marsh zones. This indicates a high demand for $\mathrm{N}$ in high salt marsh elevations opposed to low marsh elevations where stabilisation was only marginally affected by nutrient additions (Bouma et al., 2001). In the latter, tidal inundation ensures a regular nutrient input through the sea water resulting in a gradient of demand for $\mathrm{N}$ similar to the gradient in elevation (Deegan et al., 2012). Therefore, invertebrates in Pio or Low have to adapt to cope with abiotic constraints from the sea water (introduced in chapter 3), such as the sealing of spiracles to survive inundation performed by Spelobia stercoraria, rather than evolving strategies to outcompete other species for nutrients, such as the formation of maggot balls by Hydrotaea dentipes (Skidmore, 1985; Smith, 1989). These patterns are not only observed within the fauna or microorganisms but also in the floral domain: In chapter 5 we explained a general trend towards a higher density of fine roots with lower plant available phosphorous. Plants invest more in aboveground tissue compared to roots when nutrients are available in sufficient amounts (Darby \& Turner, 2008; Valiela, 2013; Johnson et al., 2016). In this respect it must be mentioned that FRM also depends on grain size distribution of the upper soil within the salt marsh: As soils with larger mean grain sizes are prone to erosion by wave energy, plants must invest more to anchor themselves in sandy sediments (van Eerdt, 1985; Allen, 1989). In conclusion, we can expect a high FRM if nutrients are low and the upper soil has a high content of sand. Additionally, when nutrients are scarce, another factor appears to become more important in accordance with FRM: Chapter $\mathbf{5}$ showed that FRM is highest in Low, a zone with limited plant available phosphorous and the highest species diversity among all three salt marsh zones. Hence, plant species compete for nutrients which is reflected in a high amount of FRM and belowground space occupation similar to other studies in terrestrial environments (Fransen et al., 2001; Leuschner et al., 2001).

Organic matter balances are not only influenced by the total mass of nutrient input or output. Regarding the PE, the stoichiometry of nutrients is a key factor which 
has consequences for carbon gains and losses in soils. Moreover, PEs of terrestrial and aquatic/marine ecosystems are vastly different from each other: In freshwater planktonic ecosystems, priming has been suggested to emerge on pulsed availability of labile carbon (Bianchi, 2011) or due to spatial proximity of auto- and heterotrophic microbial populations (Guenet et al., 2010). However, in these systems, bacterial cells might invest the energy of available labile carbon directly into growth and accumulation of biomass instead of production of extracellular enzymes, which are required to increase the exploitation of ambient recalcitrant carbon (Catalán et al., 2015). In a structurally stable environment such as a soil, the availability of OM is highly constrained (Jobbágy \& Jackson, 2001) and labile carbon pulses can occur on a sporadic level. In such an environment, priming might be a successful ecological strategy allowing heterotrophic microbial populations to endure periods of labile carbon shortage (Catalán et al., 2015). In salt marsh ecosystems these PE patterns occur simultaneously and spatially confounded.

Derived from hypothesis of Guenet et al. (2010), possible interactions within a salt marsh ecosystem that lead to PEs are shown in Figure 6.1: Labile organic matter (LOM) is supplied to the soil through tidal inundation in the form of plant detritus and phytoplankton exudates (McKinley \& Vestal, 1992). LOM decomposer synthesis specific enzymes capable of degrading LOM and thus providing the LOM decomposer with energy. Moreover, the flush of easily degradable substances enables LOM decomposer to synthesise LOM enzymes. As a secondary effect, these enzymes degrade recalcitrant organic matter (ROM) in the soil into catabolites, thereby supplying another microbial community with enough energy and nutrients to synthesise ROM-specific enzymes degrading available ROM substrates in the soil. This co-metabolism leading to PEs was shown experimentally and reviewed in other studies (Kuzyakov et al., 2000; Hamer \& Marschner, 2005; Blagodatskaya et al., 2011). Another possible pathway is the direct utilisation of degraded LOM by ROM decomposers for their catabolism. They invest the energy derived from LOM products to synthesise ROM enzymes which provides the limiting nutrients and structural $\mathrm{C}$ for both decomposer communities. This mutualism was described in general context and with special emphasis on salt marsh ecosystems in various studies (Bertness \& Leonard, 1997; Kuzyakov, 2002; Fontaine \& Barot, 2005). While 
both pathways (co-metabolism and mutualism) are expected to occur simultaneously, distribution of LOM and ROM in the salt marsh soil is likely to be spatially heterogenous: LOM is mostly replenished by inundation and tides in Pio and Low, whereas ROM is stored in considerable amounts in the soil of higher elevations (Low and Upp). The mechanisms above state the situation of a positive PE. However, it has to be mentioned that there is also the possibility of a negative PE, which happens when the most active part of microorganisms switch from decomposition of ROM to added LOM, a term called "preferential substrate utilisation (PSU)" (Cheng, 1999; Kuzyakov et al., 2000; Blagodatskaya et al., 2007; Kuzyakov \& Bol, 2006). As an example, no or negative PE was found in a lake water experiment comparable to my results in chapter 2 under constant flooded conditions (Catalán et al., 2015).

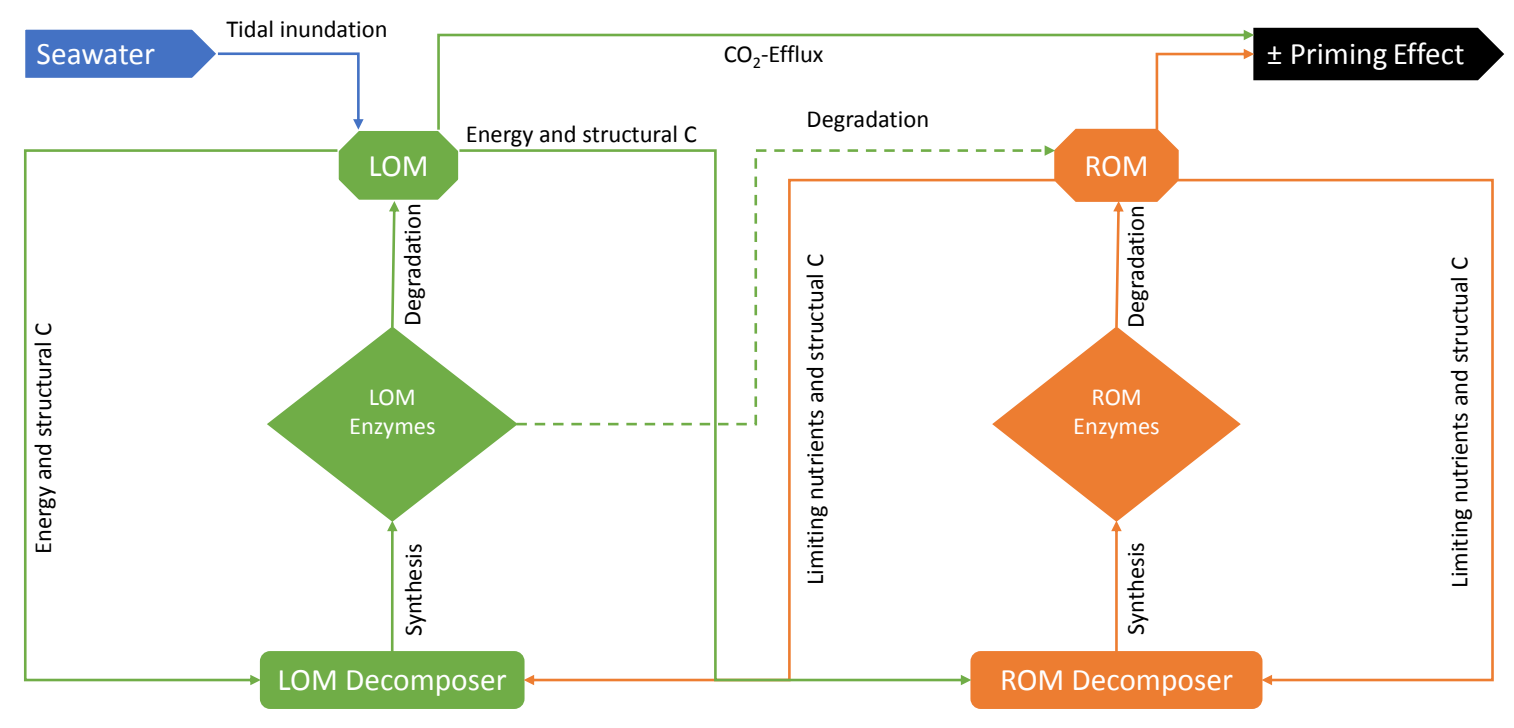

Pioneer Zone Lower Saltmarsh Zone Upper Saltmarsh Zone

Figure 6.1 Hypothesis of Priming Effects in the salt marsh ecosystem involving two mechanisms of co-metabolism and mutualism and two different forms of organic matter: Labile (LOM) and recalcitrant (ROM) (modified after Guenet et al., 2010).

As seen in chapter 4, the stabilisation of OM seems to be negatively affected by an increased nutrient level of the water: A regular input of LOM and nutrients from sea water through tidal inundation could supply initial energy for microorganisms to decompose ROM stored inside the salt marsh sediment. An indication for such a PE can be observed in the clearly reduced OM stabilisation within the upper salt marsh 
under nutrient enriched conditions: N-limited microbial communities within Upp use labile, N-rich OM to mineralise recalcitrant, plant-based OM (see chapter 4). The lack of this effect in Low elevations indicates that these zones are not N-limited. Nevertheless, I showed in chapter 2 that PE in Low is generally higher than in Pio. In addition to the already mentioned reasons, this is a direct consequence from a high nutrient level of the soil in this zone leading to a high PE-potential if LOM or/and a sufficient amount of moisture is supplied (Bianchi, 2011).

\subsection{Conclusions and outlook}

My investigations have shown that nearly all biotic and abiotic parameters within the salt marsh ecosystem are linked directly or indirectly towards tidal conditions making it the primary key to understand this environment. The dominance of this factor manifests itself as a double-edged sword concerning the influence on the salt marsh system: Chapter 2 showed that flooded soils hamper decomposition due to reduced gas diffusion and anoxic state of soil. However, temporal flooding promotes decomposition in some cases via supply of water. The balance between decomposition and sequestration of $\mathrm{C}$, as emphasised in chapter $\mathbf{4}$, determines the stability of a tidal marsh. A higher sequestration means a gradual gain in elevation. However, this effect is confined due to an increased decomposition in higher elevations. In the decay study (chapter 3) biomass loss in Upp was faster than in Pio, which I called an "conservation effect" of sea water.

Nevertheless, inundation by sea water flushes the system with labile organic matter (LOM) which is easily degradable. These residues of marine organic matter are likely to constitute initial energy for biota to decompose more recalcitrant organic matter (ROM) leading to an increased $\mathrm{CO}_{2}$ respiration (positive $\mathrm{PE}$ ) as seen in a lowered stabilisation of fresh plant residues under higher inundations in chapter 4. Naturally, the "conservation effect" of sea water is closely linked to high salt concentrations favouring salt tolerant species in lower elevations of the salt marsh. To be able to exist under high salinity levels and sulphide concentrations toxic to other species, fauna and flora have developed various mechanisms ranging from the exclusion or excretion of water thereby lowering osmotic stress to the aeration of the rhizosphere to oxidise sulphides. These pioneer plants and biofilms are also 
important parameters that help the salt marsh to keep pace with the sea level by trapping sediment particles (chapter 5): A zone with higher inundation frequencies is prone to higher mean water velocity which implies a deeper root system by the plants to anchor themselves in the sediment. The good adaptation of these pioneer plants to the environmental conditions can be observed through the analysis of the fine root mass (FRM) which is minorly affected by salinity or anoxia, a direct consequence from increased inundation. Hence, this is a good example for the ambiguity of tidal inundation: It restricts flora and fauna due to constrained conditions but also enables a unique biocenosis which would otherwise be outcompeted by terrestrial biota.

Regarding future developments, I am convinced that the islands constructed in the initial project "BEFmate" will rise in significance. While the chapters in this thesis mostly concentrated on natural aspects of the salt marsh of Spiekeroog, my gathered data of the islands' soil can be used as a sparking point for long-term measurements. They reflect the initial status and show hints what could happen in the future if man-made changes continue. Regionally spoken, this means e.g. the loss of fine sediment by diking: A smaller profile through the Wadden Sea caused by prograding diking activities lead to a bottleneck effect with higher stream velocity and hence the inhibition of sedimentation of finer mineral (clay or silt) and organic (detritus) particles (Flemming \& Nyandwi, 1994). On a global scale, it is common sense that mean sea levels rise and storm currents increase in intensity. Remarkably, these two climate change induced factors could have antagonistic consequences for salt marshes: Sedimentation on the marshes surface can be highly intensified during storm currents in comparison to normal deposition during regular inundation (Stumpf, 1983). In a modelling approach, the threshold point of the sea level rise for salt marsh survival (until 2100) was estimated to $19-22 \mathrm{~mm} \mathrm{a}^{-1}$ (Schuerch et al., 2013). This value could be increased by up to $3 \mathrm{~mm} \mathrm{a}^{-1}$ with increasing storm frequency (Schuerch et al., 2013). In the experimental islands we simulated climate change scenarios by settling sods from Low into elevations of Pio. Future investigations could focus on these elevations and examine gaseous exchange of former higher elevated soils under higher inundation status. The combination of the high nutrient contents of the Wadden Sea and the rising temperatures of surface water might also lead to an increased number of "dead-zones", as already seen today 
in the Baltic Sea. Other studies could be carried out in close collaboration with plant ecologists and soil specialists investigating questions concerning higher inundated salt marsh elevations: How fast do pioneer plants colonise former competition-based environments? How vulnerable to increased erosion is a formerly dense settled lower salt marsh zone with only bare patches of pioneer plants? Does the intensified formation of cliffs due to a less dense root system in this newly formed pioneer zone destabilise the salt marsh system (see Bakker et al., 1993)?

Countless other questions arise when dealing with this fast-changing environment. However, in the natural system, even greenhouse effects are not fast enough to show the public what are the consequences of their behaviour. This is the unique strength of the experimental islands, to show today, what could happen tomorrow. Therefore, it is important to keep this exceptional experiment running and continue monitoring. 


\section{References}

Allen, J. R. L. (1989). Evolution of salt-marsh cliffs in muddy and sandy systems: a qualitative comparison of British west-coast estuaries. Earth Surface Processes and Landforms, 14(1), 85-92.

Bakker, J. D., De Leeuw, J., Dijkema, K. S., Leendertse, P. C., Prins, H. T., \& Rozema, J. (1993). Salt marshes along the coast of the Netherlands. NetherlandsWetlands, 73-95.

Bakker, J. P. (2014). Ecology of Salt Marshes: 40 Years of Research in the Wadden Sea.

Barbier, E. B., Hacker, S. D., Kennedy, C., Koch, E. W., Stier, A. C., \& Silliman, B. R. (2011). The value of estuarine and coastal ecosystem services. Ecological Monographs, 81(2), 169-193.

Bartlett, K. B., \& Harriss, R. C. (1993). Review and assessment of methane emissions from wetlands. Chemosphere, 26, 261-320.

Beck, M., \& Brumsack, H. J. (2012). Biogeochemical cycles in sediment and water column of the Wadden Sea: the example Spiekeroog Island in a regional context. Ocean \& Coastal Management, 68, 102-113.

Bertness, M. D., \& Leonard, G. H. (1997). The role of positive interactions in communities: lessons from intertidal habitats. Ecology, 78(7), 1976-1989.

Bianchi, T. S. (2011). The role of terrestrially derived organic carbon in the coastal ocean: A changing paradigm and the priming effect. PNAS, 108(49), 1947319481.

Blagodatskaya, E. V., Blagodatsky, S. A., Anderson, T. H., \& Kuzyakov, Y. (2007). Priming effects in Chernozem induced by glucose and $\mathrm{N}$ in relation to microbial growth strategies. Applied Soil Ecology, 37(1-2), 95-105.

Blagodatskaya, E., Yuyukina, T., Blagodatsky, S., \& Kuzyakov, Y. (2011). Three-sourcepartitioning of microbial biomass and of $\mathrm{CO} 2$ efflux from soil to evaluate mechanisms of priming effects. Soil Biology and Biochemistry, 43(4), 778-786.

Blum, L. K., \& Christian, R. R. (2004). Belowground production and decomposition along a tidal gradient in a Virginia salt marsh. The Ecogeomorphology of Tidal Marshes, 59, 47-73.

Bouma, T. J., Koutstaal, B. P., Van Dongen, M., \& Nielsen, K. L. (2001). Coping with low nutrient availability and inundation: root growth responses of three 
halophytic grass species from different elevations along a flooding gradient. Oecologia, 126(4), 472-481.

Burdige, D. J. (1991). The kinetics of organic matter mineralization in anoxic marine sediments. Journal of Marine Research, 49(4), 727-761.

Canfield, D. E. (1994). Factors influencing organic carbon preservation in marine sediments. Chemical Geology, 114(3-4), 315-329.

Catalán, N., Kellerman, A. M., Peter, H., Carmona, F., \& Tranvik, L. J. (2015). Absence of a priming effect on dissolved organic carbon degradation in lake water. Limnology and Oceanography, 60(1), 159-168.

Caumette, P., Cohen, Y., \& Matheron, R. (1991). Isolation and characterization of Desulfovibrio halophilus sp. nov., a halophilic sulfate-reducing bacterium isolated from Solar Lake (Sinai). Systematic and Applied Microbiology, 14(1), 33-38.

Cheng, W. (1999). Rhizosphere feedbacks in elevated $\mathrm{CO}_{2}$. Tree Physiology, 19(4-5), 313-320.

Darby, F. A., \& Turner, R. E. (2008). Effects of eutrophication on salt marsh root and rhizome biomass accumulation. Marine Ecology Progress Series, 363, 63-70.

Deegan, L. A., Johnson, D. S., Warren, R. S., Peterson, B. J., Fleeger, J. W., Fagherazzi, S., \& Wollheim, W. M. (2012). Coastal eutrophication as a driver of salt marsh loss. Nature, 490(7420), 388.

Flemming, B. W., \& Nyandwi, N. (1994). Land reclamation as a cause of fine-grained sediment depletion in backbarrier tidal flats (southern North Sea). Netherland Journal of Aquatic Ecology, 28(3-4), 299-307.

Fontaine, S., Mariotti, A., \& Abbadie, L. (2003). The priming effect of organic matter: a question of microbial competition? Soil Biology and Biochemistry, 35(6), 837843.

Fontaine, S., \& Barot, S. (2005). Size and functional diversity of microbe populations control plant persistence and long-term soil carbon accumulation. Ecology Letters, 8(10), 1075-1087.

Fransen, B., de Kroon, H., \& Berendse, F. (2001). Soil nutrient heterogeneity alters competition between two perennial grass species. Ecology, 82(9), 2534-2546. 
Guenet, B., Danger, M., Abbadie, L., \& Lacroix, G. (2010). Priming effect: bridging the gap between terrestrial and aquatic ecology. Ecology, 91(10), 2850-2861.

Hackney, C. T. (1987). Factors affecting accumulation or loss of macroorganic matter in salt marsh sediments. Ecology, 68(4), 1109-1113

Halupa, P. J., \& Howes, B. L. (1995). Effects of tidally mediated litter moisture content on decomposition of Spartina alterniflora and S. patens. Marine Biology, 123, 379-391.

Hamer, U., \& Marschner, B. (2005). Priming effects in soils after combined and repeated substrate additions. Geoderma, 128(1-2), 38-51.

Hemminga, M. A., De Leeuw, J., de Munek, W., \& Koutstaal, B. P. (1991). Decomposition in estuarine salt marshes: the effect of soil salinity and soil water content. Vegetatio, 94(1), 25-33.

Jobbágy, E. G., \& Jackson, R. B. (2001). The distribution of soil nutrients with depth: global patterns and the imprint of plants. Biogeochemistry, 53(1), 51-77.

Johnson, D. S., Warren, R. S., Deegan, L. A., \& Mozdzer, T. J. (2016). Saltmarsh plant responses to eutrophication. Ecological Applications, 26(8), 2649-2661.

Kirwan, M. L., Langley, J. A., Guntenspergen, G. R., \& Megonigal, J. P. (2013). The impact of sea-level rise on organic matter decay rates in Chesapeake Bay brackish tidal marshes. Biogeosciences, 10(3), 1869-1876.

Kirwan, M. L., \& Megonigal, J. P. (2013). Tidal wetland stability in the face of human impacts and sea-level rise. Nature, 504, 53-60.

Koop-Jakobsen, K., \& Wenzhöfer, F. (2015). The dynamics of plant-mediated sediment oxygenation in Spartina anglica rhizospheres-A planar optode study. Estuaries and Coasts, 38(3), 951-963.

Kristensen, E., Ahmed, S. I., \& Devol, A. H. (1995). Aerobic and anaerobic decomposition of organic matter in marine sediment: which is fastest? Limnology and Oceanography, 40(8), 1430-1437.

Kuzyakov, Y., Friedel, J. K., \& Stahr, K. (2000). Review of mechanisms and quantification of priming effects. Soil Biology and Biochemistry, 32(11-12), 1485-1498.

Kuzyakov, Y. (2002). Factors affecting rhizosphere priming effects. Journal of Plant Nutrition and Soil Science, 165(4), 382-396. 
Kuzyakov, Y., \& Bol, R. (2006). Sources and mechanisms of priming effect induced in two grassland soils amended with slurry and sugar. Soil Biology and Biochemistry, 38(4), 747-758.

Langley, J. A., McKee, K. L., Cahoon, D. R., Cherry, J. A., \& Megonigal, J. P. (2009). Elevated $\mathrm{CO}_{2}$ stimulates marsh elevation gain, counterbalancing sea-level rise. PNAS, 106(15), 6182-6186.

Leuschner, C., Hertel, D., Coners, H., \& Büttner, V. (2001). Root competition between beech and oak: a hypothesis. Oecologia, 126(2), 276-284.

McKinley, V. L., \& Vestal, J. R. (1992). Mineralization of glucose and lignocellulose by four arctic freshwater sediments in response to nutrient enrichment. Applied and Environmental Microbiology, 58(5), 1554-1563.

Mueller, P., Jensen, K., \& Megonigal, J. P. (2016). Plants mediate soil organic matter decomposition in response to sea level rise. Global Change Biology, 22, 404414.

Neckles, H. A., \& Neill, C. (1994). Hydrologic control of litter decomposition in seasonally flooded prairie marshes. Hydrobiologia, 286(3), 155-165.

Nyman, J. A., Walters, R. J., Delaune, R. D., \& Patrick Jr, W. H. (2006). Marsh vertical accretion via vegetative growth. Estuarine, Coastal and Shelf Science, 69(3-4), 370-380.

Ollivier, B., Caumette, P., Garcia, J. L., \& Mah, R. A. (1994). Anaerobic bacteria from hypersaline environments. Microbiological Reviews, 58(1), 27-38.

Ponnamperuma, F. N. (1972). The Chemistry of Submerged Soils. Advances in Agronomy, 24.

Schuerch, M., Vafeidis, A., Slawig, T., \& Temmerman, S. (2013). Modeling the influence of changing storm patterns on the ability of a salt marsh to keep pace with sea level rise. Journal of Geophysical Research: Earth Surface, 118(1), 84-96.

Skidmore, P. (1985). The biology of the Muscidae of the world (Vol. 29). Springer Science \& Business Media.

Smith, K. G. V. (1989). An introduction to the immature stages of British flies. Handbooks for the identification of British insects, Royal Entomological Society of London, 10, 280. 
Chapter 6

Stewart, G.R. \& Lee, J.A. (1974). The role of proline accumulation in halophytes. Planta, 120, 279-289.

Stumpf, R. P. (1983). The process of sedimentation on the surface of a salt marsh. Estuarine, Coastal and Shelf Science, 17(5), 495-508.

Valiela, I. (2013). Marine ecological processes. Springer Science \& Business Media.

van Eerdt, M. M. (1985). The influence of vegetation on erosion and accretion in salt marshes of the Oosterschelde, The Netherlands. Vegetatio, 62(1-3), 367-373.

Zahran, H. H. (1997). Diversity, adaptation and activity of the bacterial flora in saline environments. Biology and Fertility of Soils, 25(3), 211-223. 


\section{Appendix}

During the BEFmate-(Biodiversity and Ecosystem Functioning across marine and terrestrial ecosystems) project, experimental islands were established in the tidal flat of Spiekeroog in approx. $400 \mathrm{~m}$ distance to the shoreline being adjusted in height to the three main elevations found in the natural salt marsh (pioneer zone, lower salt marsh zone and upper salt marsh zone) (Figure A1, A2).

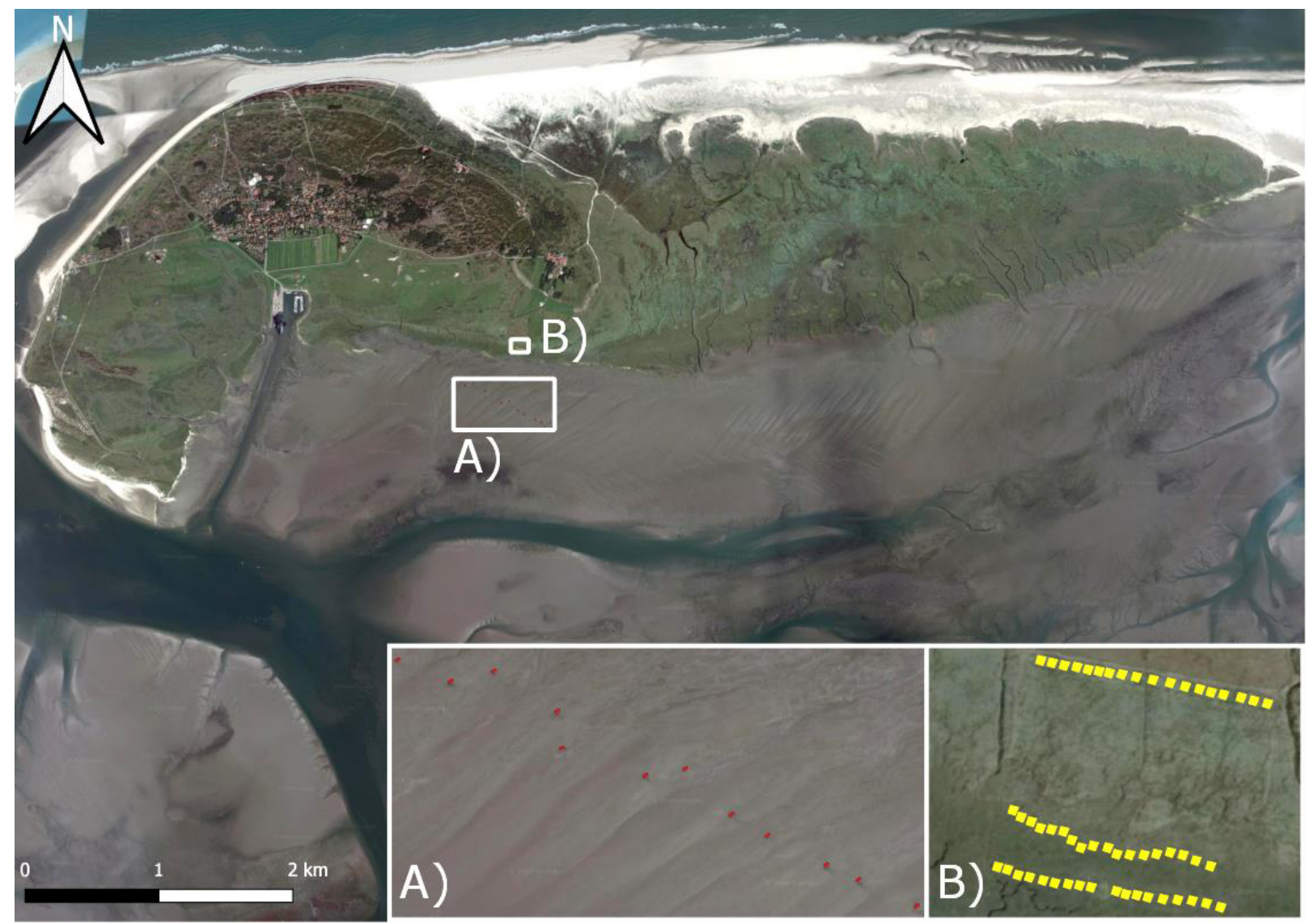

Figure A1 Top: Satellite image of Spiekeroog in the Wadden Sea; A) Experimental islands (red) within the Wadden Sea; B) Salt marsh onshore plots (yellow) aligned in lines corresponding to the three salt marsh zones Pio, Low and Upp; (Source: Google Maps, 2017). 

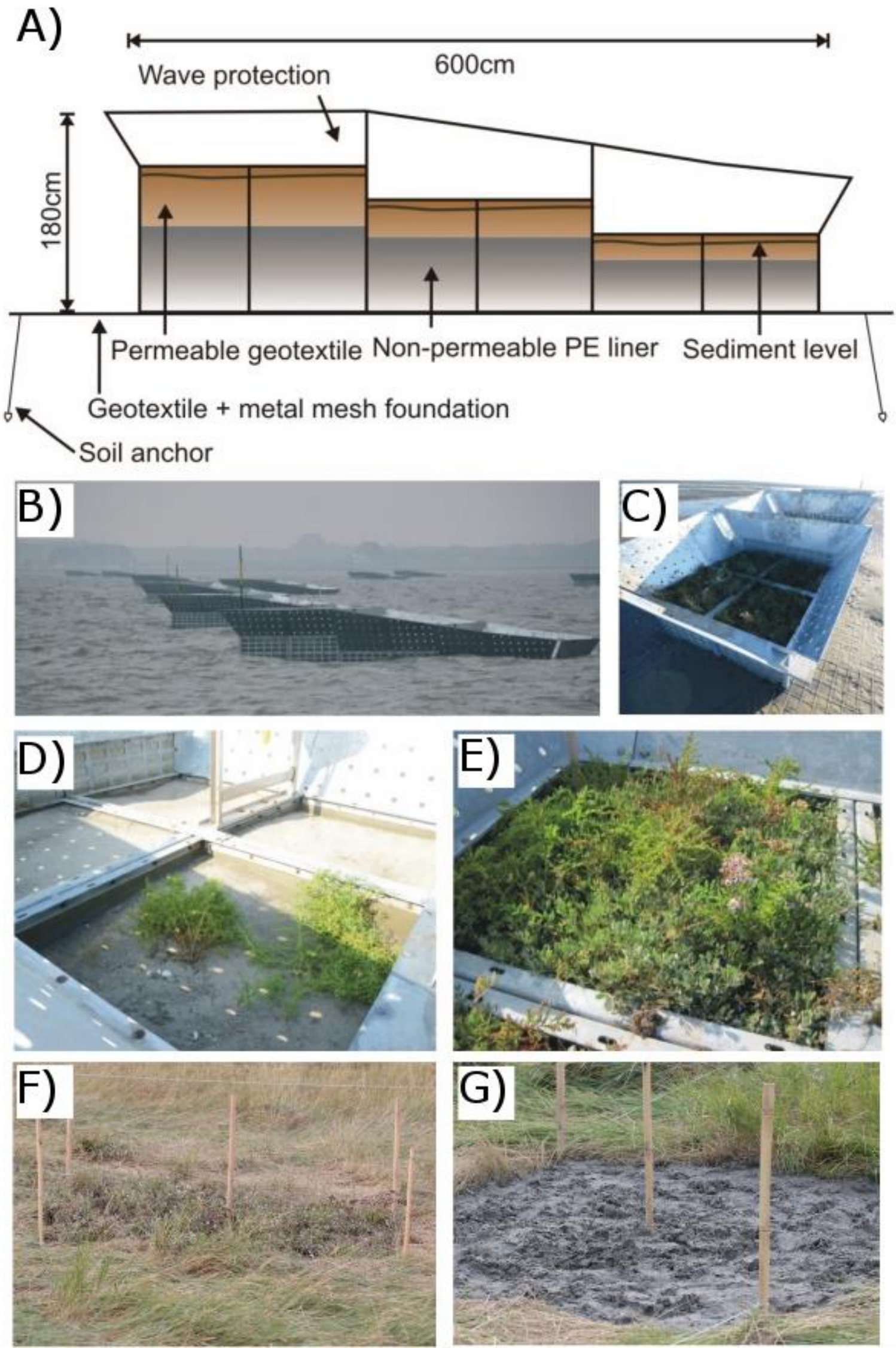

Figure A2 A) Dimensions and design of experimental islands (EI) with geotex and polyethylene-bags for water retention and approximated level of sediment filling; B) EI in high tide conditions; C) Top view on EI; D) EI with pure sand filling after one year of settlement and colonization; E) Low-vegetation on EI; F) Low-vegetation of salt marsh plots; G) Salt marsh plots with pure sand fill (changed after Balke et al., 2017) 


\section{Acknowledgements}

A project like this cannot be done without the help of supporters. Although it is impossible to remember everybody who helped me completing my project, I want to convey my special thanks to

Yakov Kuzyakov for giving me the opportunity to achieve this goal and to Michaela Dippold for taking on as my supervisor. Both always helped me understanding scientific connections and relations.

Michael Kleyer as my co-supervisor and "mastermind" behind the experimental islands. I am glad, that the monitoring of the islands continues!

Stefan Scheu, Ina Meier, Gerhard Gerold, Mark Maraun for their agreement to be part of my examination board.

The "Niedersächsisches Vorab der Volkswagen-Stiftung" and the Lower Saxony Ministry of Science for funding the BEFmat-Project.

The administration of the Wadden Sea National Park for allowing us to perform field campaigns on the Spiekeroog island and its salt marshes.

The research centre Wittbülten on Spiekeroog island for accommodation.

Matthias Gube, Peter Gernandt, Jane Blagodatskaya, Jens Dyckmans for very interesting scientific discussions and many valuable suggestions! I hope, I could also give back some ideas for your own work.

My student assistants Yang Liu, Yannik Wardius and Thorben Frahm, who always worked thoroughly and helped me during my time-consuming lab experiment. My fellow BEFmate colleagues who became friends to me during the project: Regine Redelstein, Hagen Andert, Niklas Buhk, Simone Geihser, Gesine Lange, Jennifer Schmidt, Thorsten Balke, Kristin Thomsen. I think when a project welds together former unknown people that much, that they invite them on their weddings, then this must be the best epitome of the phrase "teamwork"!

The colleagues and friends of my department: Thomas Zilla, Joscha Becker, Nina Hennings, Maire Holz, Bahar Razavi, Carolin Apostel, Callum C. Banfield, Sebastian Loeppmann, Kyle Mason-Jones. Sometimes when things did not work out how they should, the coffee-time was the highlight of my day... Thanks guys! 
Acknowledgements

Our technical assistants Karin Schmidt, Anita Kriegel, Ingrid Ostermeyer, Reinhard Langel, Susann Enzmann, Norman Loftfield, Dirk Böttger, Kerstin Langs, who measured my samples with lightning speed (most of the time).

My family and friends distracting me from and supporting me in my work and at the same time understanding why I am often very busy.

And of course, I am very grateful to have you, Klara, by my side supporting me throughout the PhD and being my lantern in grim moments! 


\section{Curriculum Vitae}

Personal information

Name

Thomas Dinter

Date and Place of birth

March $8^{\text {th }} 1986$, Recklinghausen (Germany)

Nationality

German

\section{Education}

Since 2014

2010-2013

2007-2010

PhD student at the department of „Soil Science of Temperate Ecosystems" within the $\mathrm{PhD}$ program "Biodiversity and Ecology", University of Göttingen

Master student (MSc) in Geoscience (Specialization: Geobiology), University of Göttingen

Bachelor student (BSc) in Geoscience, University of Göttingen

\section{Working experience}

Since 2017

Consultant at the Landesamt für Bergbau, Energie und Geologie (LBEG), Clausthal-Zellerfeld

2010-2013

Student assistant at the departments „Geobiology“ and „Sedimentology/Environmental Geology”, University of Göttingen

\section{Publications}

Lange, G., Haynert, K., Dinter, T., Scheu, S., \& Kröncke, I. (2018). Adaptation of benthic invertebrates to food sources along marine-terrestrial boundaries as indicated by carbon and nitrogen stable isotopes. Journal of Sea Research, 131, $12-21$. 
Redelstein, R., Dinter, T., Hertel, D., \& Leuschner, C. (2018). Effects of Inundation, Nutrient Availability and Plant Species Diversity on Fine Root Mass and Morphology Across a Saltmarsh Flooding Gradient. Frontiers in plant science, 9, 98.

Mueller, P., Schile-Beers, L. M., Mozdzer, T. J., Chmura, G. L., Dinter, T., Kuzyakov, Y., de Groot, A. V., Esselink, P., Smit, C., D'Alpaos, A., Ibáñez, C., Lazarus, M., Neumeier, U., Johnson, B. J., Baldwin, A. H., Yarwood, S. A., Montemayor, D. I., Yang, Z., Wu, J., Jensen, K., and Nolte, S. (2018). Global-change effects on earlystage decomposition processes in tidal wetlands - implications from a global survey using standardized litter, Biogeosciences, 15, 3189-3202.

Dinter T., Geihser S., Gube M., Daniel R., Kuzyakov Y. Impact of sea level change on coastal soil organic matter, priming effects and microbial community assembly. Submitted to FEMS Microbial Ecology

Andert H., Dinter T., Tscharntke T., Piskurek O., Scheu S., Kuzyakov Y., Scherber C. Diversity of decomposing flies and carcass decay in experimental salt-marsh islands of the North Sea. In preparation to be submitted to Proceedings of the Royal Society $B$

\section{Presentations and posters}

Poster: „New method for the simulation of tides in mesocosms in order to analyze C turnover and soil respiration“, Conference Meeting of Deutsche Bodenkundliche Gesellschaft (DBG), Munich, September 2015

Presentation: "Carbon and nutrient dynamics in natural saltmarshes and artificial islands in the Wadden Sea", Coastal Ecology Workshop (CEW), Westerhever, November 2015

Presentation: "Monitoring the effect of sea level change on soils from salt marshes in the Wadden Sea with experimental islands", Ecological Society of America (ESA) Annual Meeting, Fort Lauderdale, Florida, August 2016 


\section{Declaration of originality and certificate of ownership}

I, Thomas Dinter, hereby confirm that I am the author of the present thesis entitled "Soil developments in salt marshes and on artificial islands in the Wadden Sea" and that it describes my own work. It was conducted independently and not submitted somewhere else as part of a dissertation procedure.

Furthermore, I declare that no other references and sources than the acknowledged were used and that those used are appropriately cited.

Göttingen, July $12^{\text {th }}, 2018$

Thomas Dinter 